\author{
UNIVERSIDADE DE SÃO PAULO - USP \\ FACULDADE DE ARQUITETURA E URBANISMO - FAU
}

SILVIA M. R. VALENTINI

\title{
Os Sentidos da Paisagem
}



SILVIA M. R. VALENTINI

\section{Os Sentidos da Paisagem}

Tese apresentada à Faculdade de Arquitetura e Urbanismo da Universidade de São Paulo para obtenção do título de Doutor em Arquitetura e Urbanismo

Área de Concentração: Paisagem e Ambiente

Orientador: Prof. Dr. Euler Sandeville Jr.

São Paulo

2012 
AUTORIZO A REPRODUÇÃO E DIVULGAÇÃO TOTAL OU PARCIAL DESTE TRABALHO, POR QUALQUER MEIO CONVENCIONAL OU ELETRÔNICO, PARA FINS DE ESTUDO E PESQUISA, DESDE QUE CITADA A FONTE.

E-MAIL: rato@uol.com.br

projetopontoaponto@uol.com.br

Valentini, Silvia M. R.

V161s Os sentidos da paisagem / Silvia M. R. Valentini . - São

Paulo, 2012.

294 p. : il.

Tese (Doutorado - Área de Concentração: Paisagem e Ambiente) - FAUUSP.

Orientador: Euler Sandeville Jr

1. Paisagem urbana 2. Deficiência visual 3. Percepção sensória 4. Fenomenologia da percepção 5. Preconceito I. Título

CDU 711.4.01

Capa: Arte de Silvia Valentini, mostra marcas de passos e de toques de bengala no caminho cinza escuro de uma pessoa cega.

Fotos: As fotos sem crédito são de autoria de Silvia Valentini. 
Nome: VALENTINI, Silvia M. R.

Título: Os Sentidos da Paisagem

Tese apresentada à Faculdade de Arquitetura e Urbanismo da Universidade de São Paulo para obtenção do título de Doutor em Arquitetura e Urbanismo

Aprovado em:

Banca Examinadora

Prof. Dr.

Julgamento:

Prof. Dr.

Julgamento:

Prof. Dr.

Julgamento:

Prof. Dr.

Julgamento:

Prof. Dr.

Julgamento:
Instituição:

Assinatura:

Instituição:

Assinatura:

Instituição:

Assinatura:

Instituição:

Assinatura:

Instituição:

Assinatura: 

Para

Juliana

Felipe

Mariana

e

Nicolas e Leonardo, que já arquitetam o futuro. 



\section{Agradecimentos}

À Faculdade de Arquitetura e Urbanismo da Universidade de São Paulo, alma mater.

Ao Professor Euler Sandeville Jr., por me receber na FAU e acolher a minha pesquisa.

A todos os autores, construtores do conhecimento, que abriram

caminhos para que este trabalho pudesse ser realizado.

Aos meus amigos que não enxergam com os olhos, guias na percepção da paisagem.

Aos bibliotecários das unidades FAU, FFLCH, IP e ECA, pelo

atendimento solícito, pelas informaçóes e o primoroso trabalho

de manutenção e disponibilização do rico acervo. 

Sou um guardador de rebanhos O rebanho é o meu pensamento E os meus pensamentos são sensaçóes Penso com os olhos e com os ouvidos E com as mãos e os pés E com o nariz e a boca.

Pensar uma flor é vê-la e cheirá-la

E comer um fruto é saber-lhe o sentido

Por isso quando num dia de calor

Me sinto triste de gozá-lo tanto

E me deito ao comprido na erva,

E fecho os olhos quentes,

Sinto todo o meu corpo deitado na realidade,

Sei a verdade e sou feliz.

[...]

O que é preciso é ser-se natural e calmo

$\mathrm{Na}$ felicidade ou infelicidade,

Sentir como quem olha

Pensar como quem anda

[...]

Às vezes, de repente, bate-me a Natureza de chapa

$\mathrm{Na}$ cara dos meus sentidos,

E eu fico confuso e perturbado, querendo perceber

Não sei bem como nem o quê

[...]

O essencial é saber ver,

Saber ver sem estar a pensar,

Saber ver quando se vê,

E nem pensar quando se vê

Nem ver quando se pensa.

Mas isso (tristes de nós que trazemos a alma vestida!),

Isso exige um estudo profundo

Uma aprendizagem de desaprender

\section{Fernando Pessoa}

Obra Poética

Companhia José Aguilar Editora, 1972. p. 212 e 216 



\section{Resumo}

Esta pesquisa investiga a percepção espacial que pessoas com deficiência visual têm da paisagem urbana. Compreende igualmente a sociabilidade das pessoas cegas com outros cidadãos, trazendo as questóes do afeto, do conflito, do estranhamento, do estigma e do preconceito. Procura identificar os mecanismos subjetivos e emocionais de valoração do espaço que surgem durante os percursos, sem esquecer as condições físicas em que eles são feitos. Busca no reconhecimento de suas memórias os valores e a afeição pela paisagem. Entendendo que a paisagem é patrimônio coletivo e de partilha, pessoas cegas reclamam um tratamento igual de cidadáos e o acesso a ela, de maneira plena e independente. Pessoas com deficiência visual querem ser ouvidas e percebidas na cidade pelos seus talentos e capacidades, enquanto que a população insiste em reconhecê-las e rotulá-las apenas pelo que lhes falta.

Palavras-chave: Paisagem urbana. Deficiência visual. Percepção sensória. Fenomenologia da percepção. Preconceito.

\section{Abstract}

This work researches the spatial perception that visual impaired persons have of the urban landscape. It also covers the social interactions of blind people with other citizens, discussing aspects of sympathy, conflicts, stigma, and prejudice. Furthermore, it seeks to identify the emotional - and subjective - mechanisms of evaluating the space that arise through the pathways, not disregarding its physical attributions. In addition it looks for the remembrance of values and affection towards the landscape. Based on the understanding that the urban landscape is a public and shared heritage, the visual impaired person claim equal treatment of citizens and independent access to it. People with visual impairment want to be heard and accepted for their talent and potential, while the population insists in recognizing and labeling them only for their disability.

Keywords: $\quad$ Urban landscape. Visual impairment. Sensorial perception.

Phenomenology of perception; Preconception. 



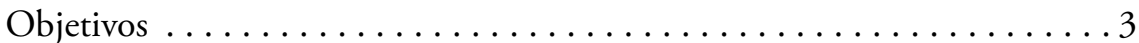

Hipótese .....................................4 4

Justificativa ................................. 4

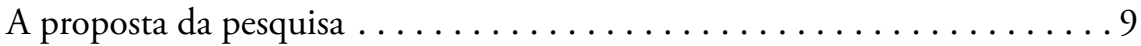

Percebendo com o corpo todo .........................11

Outras contribuiçóes............................... 16

Base Teórica ................................... 19

Procedimentos metodológicos.......................26

A deficiência visual ...............................28

O envolvimento com o tema $\ldots \ldots \ldots \ldots \ldots \ldots \ldots \ldots \ldots \ldots 29$

O desenvolvimento da pesquisa acadêmica $\ldots \ldots \ldots \ldots \ldots \ldots \ldots \ldots 30$

Os protagonistas .................................... 32

Capítulo 1 A contribuição teórica sobre paisagem . . . . . . . . . . 47

A paisagem percebida pelos autores.......................58

Capítulo 2 Pessoas cegas não enxergam com os olhos $\ldots \ldots \ldots \ldots 77$

A deficiência visual ............................... 82

A percepçáo do entorno ............................ 85

Aceitar... ou aceitar .............................. 93

$\mathrm{Eu}$, cidadão, por detrás destes olhos .................... 95

A hegemonia da visão e o peso da diferença. .................. 108

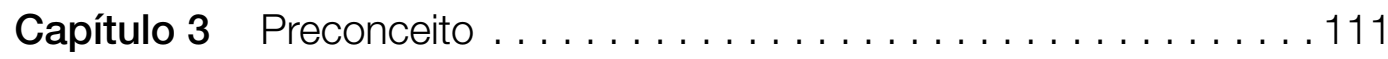

Quem é igual e quem é diferente? ......................115

É muito mais fácil ser cego do que ser visto como cego. ............116

O ser humano é bem complicado ..................... 130

Se sou diferente de ti, longe de te lesar eu te aumento . . . . . . . . 133

Invisuais ou invisíveis?............................ 140

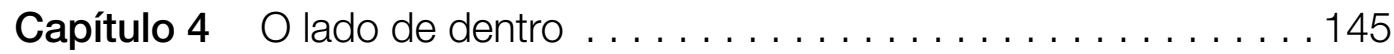

Os espaços da memória............................... 148

Eu me lembro também que o meu vô descascava as laranjas........... 158

Espaços recortados ............................... 166

Eu estava lá, ela viu a minha pessoa, gostou. ................ 170

Capítulo 5 Os sentidos da paisagem $\ldots \ldots \ldots \ldots \ldots \ldots \ldots \ldots 177$

O compasso da metrópole.............................. 187

Barreiras físicas e sociais . .........................200

A pele lê a textura .................................204

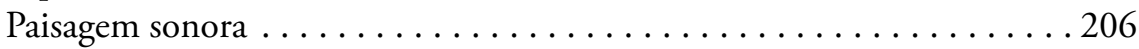

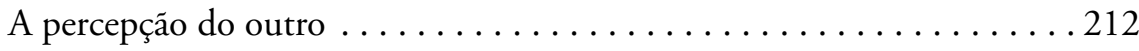

Memórias passageiras ............................214

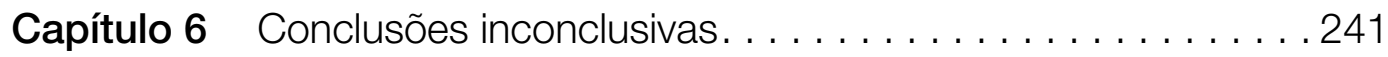

Contribuiçóes para uma cidade mais amigável. ................244

Anexos Referências ...................................273

Projeto Ponto a Ponto . . . . . . . . . . . . . . . . . . . . . 289 



\title{
INTRODUÇÃO
}

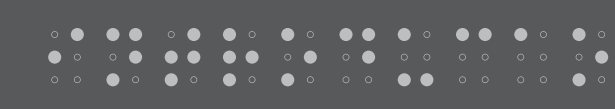

\author{
Só escuto as paisagens há mil anos \\ Chegam aromas de amanhã em mim \\ Tem um cheiro de malva esta manhá \\ Quero apalpar o som das violetas \\ Cheiroso som de asas vem do sul \\ Escuto a cor dos peixes \\ Hoje eu desenho o cheiro das árvores
}

Manoel de Barros ${ }^{1}$

Videntes, perdemos muito quando usamos o olhar como um scanner para a rápida apreensão da realidade. Abrimos os olhos para a paisagem e nos deixamos envolver totalmente pelo sentido mágico, capaz de aproximar o distante, fazer a síntese do complexo, comunicar em silêncio, abreviar o tempo. $\mathrm{O}$ olhar captura toda a nossa atençáo e nos faz reféns. Com os olhos abertos atuamos com rápidas apreensôes para reconhecimento imediato: o céu nublado, o nome da rua, o preço na etiqueta, as letras impressas no papel.

Quando fechamos os olhos, no entanto, nos libertamos. Abre-se um maravilhoso mundo com temperaturas, texturas, sons, odores. Passamos a perceber em outro compasso de tempo, com riqueza sinestésica de detalhes. Com os olhos fechados ficamos atentos aos sons e nos detemos primeiramen- 
te em detalhes que nos levarão ao todo. As frutas ganham textura, consistência, temperatura, peso, perfume e sabor acentuado; a pele adquire maciez, o céu nublado comunica mudança de umidade e traz a perspectiva de vento e chuva; as letras impressas têm cheiro, o papel ganha espessura.

A hegemonia da visão encarregou-se de direcionar a nossa vida para o que é visível, desdenhando o que não é possível enxergar e que exige mais tempo para a apreensão - um desperdício sensório. No ritmo corrido da comunicação visual desperdiçamos e talvez até embotamos a nossa capacidade de nos determos em uma percepção mais abrangente.

Mas não é preciso perder a visão para se trazer para o cotidiano esse mundo de sensaçóes. Basta mudar o ritmo e colocar a atenção no momento presente: a percepção pede atenção e juízo para entender a comunicação das sensaçóes. Com atenção e crítica reconheceremos o timbre de voz dos nossos amigos, a maciez da pele, as nuanças do paladar, os perfumes, a sutileza dos sabores raros ocultos nas bebidas e alimentos. Seremos capazes de perceber a mudança climática sem enxergar o céu e entender as razões do outro pelo tom da sua voz. Com a atenção voltada para as sensaçôes, para os sentidos, somos capazes de produções mais ricas, seja na interação com o outro, na construção da cidade, no arranjo do cenário, no entendimento da topografia. O olhar, per se, é pouco para tanto. Não consideremos apenas a visão, ela não é tudo ${ }^{2}$. No escuro, o recurso sequer existe. Não esperemos o apagar das luzes para atentar para os outros sentidos. Eles estão aqui, agora, à nossa disposição, almejando ser percebidos.

\section{"O pensamento de perceber"3}

Pessoas cegas não enxergam com os olhos. Enxergam com as mãos, os ouvidos, nariz, pés, com a boca, enxergam com todo o corpo ${ }^{4}$. Recebem estímulos quando estão paradas ou em movimento, percebem com a ajuda do vento, da umidade e temperatura, sentem os deslocamentos de ar. Conhecem os locais pela sua textura, guiam-se pelos sons, distinguem ruídos. Percebem pelo sentido háptico ${ }^{5}$, pelo tato ativo, intencional,

2 “[...] não contemplamos os ardentes calores, nem conseguimos, com os olhos, dar pelo frio, nem costumamos enxergar as vozes[...] não podemos ver tudo com os olhos” LUCRECIO. Da Natureza. Tradução de Agostinho da Silva. Editora Globo, 1962, p. 61 Livro I.

3 MERLEAU-PONTY, Maurice. Fenomenologia da percepção. São Paulo : Martins Fontes, 1994 p. 27

4 O Dicionário Houaiss da Língua Portuguesa define enxergar como perceber pela visão, alcançar com a vista, mas também sentir, pressentir, prever. O Dicionário Aurélio - Século XXI define enxergar como ver a custo, entrever, divisar, descortinar, avistar, notar, perceber, observar, pressentir, adivinhar. Adotei a definição "não enxergam com os olhos" a partir da experiência adquirida na convivência com pessoas cegas, por perceber que essas pessoas apenas náo enxergam com os olhos, mas percebem, sim, com todo o corpo.

5 Sistema Hápico: "O imput combinado da pele e da cinestesia constitui a base de um canal perceptual conhecido como sistema 
e também pelo tato passivo, que permite que sensaçôes sejam percebidas pela pele de todo o corpo. Calculam as distâncias percorridas com a ajuda da memória cinética ${ }^{6}$, capaz de registrar, pelo movimento do corpo, o tempo gasto nos caminhos percorridos. Percebem de maneira intuitiva, com sensibilidade e experiência, com a ajuda da memória, com as suas referências culturais e a experiência dos momentos vividos, partilhados. Entendem e se apropriam das razóes do interlocutor pela entonação da sua voz; identificam pessoas pelo seu perfume, pelos seus passos, seu jeito de chegar. Exercitam constantemente a memória, e por esse motivo destacam-se pela capacidade de acumular dados e referências. Utilizam-se de todo esse conhecimento na sua vida profissional, pessoal e social, desempenhando com eficácia e criatividade inúmeros papeis.

Nesse sentido, conviver com pessoas cegas pode nos tornar mais criativos e aptos a agir de maneira mais intensa. Caminhar pela cidade ao lado de uma pessoa que não enxerga com os olhos pode ser uma experiência multissensorial capaz de nos despertar para percepçóes das quais frequentemente não temos consciência no nosso cotidiano. A caminhada pode trazer à tona, de modo mais consciente, cenas de um passado remoto, de um presente latente e mesmo fatos dos quais não nos daríamos conta e que podem surgir, repentinamente, permeando nossas emoçóes.

Esta pesquisa procurou assim identificar os mecanismos subjetivos e emocionais de valoraçáo do espaço que surgem durante os percursos, sem esquecer as condiçóes físicas em que ele é feito. Considera que a percepçáo da paisagem compreende as memórias dessas pessoas, os valores e a afeição despertados em seus percursos. Pessoas cegas, como os outros cidadãos que enxergam com os olhos, podem perceber e considerar a paisagem como uma categoria relevante, indicadora de direcionamentos e emoçóes.

\section{Objetivos}

Este trabalho objetiva buscar, nas formas como pessoas com deficiência visual se organizam e interagem em seus percursos, contribuições para a organização do espaço, trazendo à discussão as questôes da afetividade, da representação e da interação.

háptico (do grego hapsis, que quer dizer pegar ou segurar). O sistema háptico é responsável pela percepção das propriedades geométricas - formas, dimensões e proporçóes dos objetos manipulados. Além disso, através de diversas manipulaçóes - por exemplo pegando, levantando, esfregando, apertando, esticando e seguindo contornos - o sistema háptico é capaz também de fornecer informaçóes sobre seu peso e consistência. O reconhecimento preciso de um objeto pode ser resultado apenas de um breve encontro tátil: o simples ato de tocar a borda de uma xícara sem olhá-la já nos fornece informaçóes suficientes para que orientemos nossa mão a fim de pegá-la e erguê-la." SCHIFFMAN, Harley Richard. Sensação e percepção. Rio de Janeiro, LTC, 2005

6 Pela cinestesia é possível perceber os movimentos musculares. Com a ajuda do sentido cinestésico (memória muscular), é possível subir uma escada automaticamente, sem a preocupação de medir com os pés a altura de cada degrau. 


\section{Hipótese}

A maneira como pessoas que náo enxergam com os olhos percebem e se relacionam com a paisagem dá indicaçóes para a construção de um ambiente mais significativo, mais receptivo. Essas indicaçóes podem ser usadas para uma ação transformadora desse ambiente, para enriquecer e compor uma cidade mais amigável, criando espaços de relacionamento que favoreçam interaçôes entre pessoas.

\section{Justificativa}

Este trabalho sustenta que a visão, embora seja um recurso de grande valia, não é o único instrumento de apreensão da paisagem. Entender a paisagem com o uso de outros sentidos pode ser um desafio complexo, mas instigante e enriquecedor.

Segundo Calvino ${ }^{7}$, vivemos um tempo em que os meios de comunicação atrelam as notícias mais às imagens do que ao conteúdo dos textos. A hegemonia da visão tem sido intensificada pela multiplicidade de invençóes tecnológicas que multiplicam de maneira infinita o uso da imagem, "uma enxurrada de imagens". Pagamos um preço por relegar a um segundo plano a percepçáo com o uso de outros campos sensórios.

Steven Holl ${ }^{8}$, na apresentação da obra de Pallasmaa9 reflete que em muitos projetos de arquitetura há uma distância entre o idealizado e a qualidade da habitabilidade. Acontece muitas vezes de projetos que parecem tâo bons no papel, ou na tela do computador, decepcionarem como espaço de vivência. $\mathrm{O}$ arquiteto reflete que a resposta está na exacerbaçáo do campo visual, na cultura tecnológica e de consumo que vivemos nos dias de hoje e que impregnou a prática da arquitetura e da educaçáo. Enquanto a nossa experiência de mundo é formulada pelos sentidos, para Holl, muito da arquitetura é produzida sob consideração principalmente da visão.

7 CALVINO, Ítalo. Seis propostas para o próximo milênio. São Paulo : Companhia das Letras, 1990 p. 107

8 Site do arquiteto: http://stevenholl.com - visitado em 04/04/2009

9 PALLASMAA, Juhani. The eyes of the skin-architecture and the senses. West Sussex, UK : Wiley Academy, 2008. Tradução minha. 
O impacto da cegueira é devastador em uma cultura voltada para o visual, que considera a visão o mais nobre dos sentidos e que privilegia transparências, luminosidades, cores, brilhos. Mas, ao contrário do que muitos pensam, o mundo não se encerra em trevas e a vida não acaba com a perda da visão. Pessoas que ficam cegas na vida adulta passam por uma reorganização motora e sensorial e aprendem a necessidade de apurar o seu estado de atenção, de se tornarem atentas ao que está acontecendo ao seu redor. Conforme a visão vai se apagando, essas pessoas apropriam-se de outras modalidades de percepção, capacitando-se à apreensão do cotidiano de maneira diversa.

Sacks ${ }^{10}$, apresentando a autobiografia de Hull ${ }^{11}$ indica que há evidências de alteraçóes fisiológicas, e que novas áreas do cérebro podem repor as áreas responsáveis pela perda da visão. Assim, pessoas com deficiência visual, antes habituadas a observar a chuva, passam a sentir o som da chuva, não apenas pelo reconhecimento do seu ruído, com o qual já tinham intimidade, mas pela qualidade que ela adquire de dar contorno a tudo, propiciando uma nova experiência acústica. Em recente edição, na qual relata a sua própria perda de visão, Sacks ${ }^{12}$ coloca que "é a descrição que o paciente faz do que está sentindo que estimula a exploração mais completa”. Depoimento inspirador que mostra a ciência entendida a partir dos relatos e experiências.

Em Merleau-Ponty ${ }^{13}$ encontramos que "cada percepção envolve a possibilidade de uma substituição por outra". Em interessante artigo intitulado "Como eu vejo e como os outros acham que eu não vejo", publicado pela Rede Saci ${ }^{14}$, o professor Sergio Faria, cego, comenta que "a visão encontra-se muito longe de estar circunscrita ao sentido exteriorizado pelos olhos: ela é construída na mente". E continua:

[...] Eu me sento na varanda da minha casa, que fica cerca de $50 \mathrm{~km}$ de Sáo Paulo e, diante de meus olhos mentais, o relevo brota exuberante. Os vales e as montanhas se formam ricos de detalhes decorados por grandes árvores com copas imensas e pássaros multicores. De que forma essa imagem se formou na minha mente? É porque sei que

10 Sobre Oliver Sacks: Nascido em Londres em 1933, o médico neurologista que reside em New York desde 1965 é professor de neurologia e psiquiatria do Centro Médico de Columbia University e consultor do Beth Abraham Hospital, no Bronx. É autor de vários livros, entre eles $O$ homem que confundiu sua mulher com um chapéu, Um antropólogo em Marte, $A$ ilha dos daltônicos, Vendo vozes. O seu trabalho é publicado regularmente na revista New Yorker e no New York Review of Books. http://www. oliversacks.com

11 HULL, John. Touching the rocks. Vintage, 1991. SACKS apresenta a edição de 1991. O livro foi reeditado, ampliado, sob o titulo On sight and insight. Oneworld, 1997. Consegui adquirir as duas ediçóes pela Amazon Books; a citação de SACKS está na página xiii. Tradução minha.

12 SACKS, Oliver. O olhar da mente. São Paulo : Companhia das Letras, 2010.

13 MERLEAU-PONTY, Maurice. O visivel e o invisivel. São Paulo : Editora Perspectiva, 1984. p. 49

14 Publicado em: http://saci.org.br/index.php?modulo=akemi\&parametro=7720 em 13/10/2003. Visitado em 16/05/2009 
a região é cheia de montanhas. E como eu sei disso? Fácil! Quando eu estou dentro do carro, circulando pela região, percebo que o carro sobe e desce grandes ladeiras, faz muitas curvas etc. As pessoas sempre descrevem o que veem: "Nossa, aqui é tão alto que no pôr do sol parece que estamos acima do sol". Também eu percebo o cheiro da mata, o frescor da brisa por entre as árvores etc. [....] Fica fácil montar a imagem, é como num livro, o autor descreve as imagens e você viaja junto com ele.[...]

Segundo Merleau-Ponty ${ }^{15}$, "a percepção não é a soma do visual, tátil e auditivo; percebo de maneira plena, total, com todo o ser". O autor reflete que:

O mundo da percepção, isto é, o mundo que nos é revelado por nossos sentidos e pela experiência de vida, parece-nos à primeira vista o que melhor conhecemos, já que não são necessários instrumentos nem cálculos para ter acesso a ele e, aparentemente, basta-nos abrir os olhos e nos deixarmos viver para nele penetrar. Contudo, isso não passa de falsa aparência. Eu gostaria de mostrar [...] que esse mundo é em grande medida ignorado por nós enquanto permanecemos numa postura prática ou utilitária [...]. O mundo verdadeiro não são as luzes, essas cores, esse espetáculo sensorial que meus olhos me fornecem, o mundo são as ondas e os corpúsculos dos quais a ciência me fala e que ela encontra por trás dessas fantasias sensíveis. (MERLEAU-PONTY, 2004, p. 1)

Hull ${ }^{16}$ pergunta: - por quanto tempo é preciso estar cego para que os sonhos percam suas cores? Nascido em 1935, o professor americano lutou contra problemas de visão por 48 anos. Em 1983, com pouco mais de três anos de severa perda da visão, os últimos traços de luz se apagaram. Durante esse tempo, relata ele, os seus sonhos incluíam imagens, como antes de perder a visão. Poucos meses mais tarde teve o seu primeiro sonho como sendo uma pessoa cega, "vendo-se" como pessoa cega. O autor reflete que, para videntes, a ideia de um dia agradável é basicamente visual: um dia agradável significa claridade e céu azul. No entanto para ele, explica, o vento tomou o lugar do sol, e um dia é agradável quando há uma brisa suave.

15 MERLEAU-PONTY, Maurice. Conversas - 1948. São Paulo : Martins Fontes 2004.

16 HULL, John M. On sight \& insight - a journey into the World of Blindness. Oneworld, 1997. Traduçáo minha. 
Isso traz todos os sons do meio ambiente. As folhas sussurram, pequenos pedaços de papel voam pela calçada, os muros e esquinas dos grandes prédios distinguem-se sob o impacto do vento, eu posso sentir no cabelo, na face, nas roupas. Um dia meramente morno, eu suponho que seja agradável, mas o vento torna tudo mais emocionante, pois subitamente propicia o sentido de espaço e distância. $\mathrm{O}$ trovão coloca o telhado sobre a minha cabeça, bem alto, abobadado, estrondoso. Eu entendo quando estou em um espaço grande, considerando que antes nada percebia. A pessoa que enxerga sempre tem um teto sobre sua cabeça, na forma de céu azul, nuvens, ou estrelas. $\mathrm{O}$ mesmo acontece para pessoas cegas, com o som do vento nas árvores. Ele cria árvores, a pessoa passa a se sentir cercada de árvores, quando antes não havia nada. (HULL, 1997)

Hall ${ }^{17}$ cita obra do antropólogo Edmund Carpenter sobre o mundo perceptivo dos esquimós Aivilik e a maneira como se orientam no espaço. Em dias de vento, quando a neve reduz a visibilidade a 30 metros ou menos, para sua orientaçáo os esquimós contam com o cheiro e a direção do vento, o contato da neve e do gelo, a nitidez dos contornos, a densidade em sal do ar. Os Aivilik têm mais de 12 nomes para os diferentes tipos de vento e utilizam-se dos sentidos do olfato e da audição, mais do que da visão (HALL, 1986, p. 94).

Merleau-Ponty (1994 p. 303) aponta que o corpo percebe e que os sentidos se comunicam, embora o campo tátil não tenha a mesma amplitude do campo visual. “Tocar não é ver”, aponta o autor. E cita a definição de um jovem cego sobre as dimensôes da visão: "Aqueles que veem estáo em relaçáo comigo por um sentido desconhecido que a distância me envolve inteiramente, me segue, me atravessa e que, desde que me levanto até me deitar, me mantém, por assim dizer, sob sua dominação”. O autor reflete que o mundo das pessoas cegas e das pessoas que enxergam difere "não apenas na quantidade de materiais que dispóem, mas ainda pela estrutura do conjunto. Um cego sabe exatamente, pelo tato, o que são galhos e folhas, um braço e os dedos das mãos”.

Digo que meus olhos veem, que minha mão toca, que meu pé dói, mas essas expressóes ingênuas não traduzem a minha experiência verdadeira. Elas já me dão dela uma interpretação que a afasta de seu sujeito original. Por que sei que a luz atinge os meus olhos, que os contatos se fazem pela pele, que meu sapato fere meu pé, disperso em meu corpo as percepçóes que pertencem à minha alma, coloco a percepção no percebido. Mas aquilo 
é apenas o rastro espacial e temporal dos atos de consciência. Se os considero do interior, encontro em um único conhecimento sem lugar, uma alma sem partes, e não há nenhuma diferença entre pensar e perceber, assim como entre ver e ouvir. Podemos manter-nos nessa perspectiva? Se é verdade que não vejo com os olhos, como pude ignorar sempre esta verdade? (MERLEAU-PONTY, 1994, p. 287)

O visível é o que se apreende com os olhos, o sensível é o que se apreende com os sentidos. Quando a função visual fica obstruída, primeiro há o comprometimento das cores e elas perdem a saturação; depois as cores diminuem e finalmente estaciona-se no cinza (MERLEAU-PONTY,1994, p. 30). Desta maneira, ao contrário do que pensam aqueles videntes que, com horror, dizem que "os cegos vivem nas trevas", ou "a luz se apagou", ou ainda "eles estão presos na escuridão", a maioria das pessoas cegas enxerga um cinza nebuloso. E exatamente por prescindirem da visão, essas pessoas talvez percebam o mundo de maneira mais abrangente, mais consciente e menos desatenta do que muitos videntes.

A percepção não pode ser considerada através de seus resultados, das associações. Ela é um fenômeno, precede a si mesma. Merleau-Ponty dá como exemplo uma cena de um barco encalhado na praia. Os troncos da mata, ao fundo, são da mesma cor e textura do barco. Para o olhar desatento, a imagem pode se tornar única. Para quem se detém numa observação mais acurada, as coisas se reorganizam e surge o "mundo verdadeiro" floresta e barco. Havia o pressentimento, uma tensão de que algo estaria para acontecer, como quando há nuvens e se aproxima uma tempestade. Uma vaga inquietação que organiza os elementos que antes não podiam ser associados, mas que de repente permitem a percepção correta (MERLEAU-PONTY, 1994, p. 41). De maneira que a atenção não é uma associação de imagens, mas a constituição um objeto novo.

O mundo está em constante mutação e é impossível se deter em uma percepção única, estática. Caminhar por um parque pode se tornar uma mutável experiência de percepção, já que constantemente há interferência do vento, da textura da vegetação, dos sons do ambiente, das memórias trazidas por essa experiência. E como a percepção é feita pelo corpo, a cada momento poder ser processada de maneira diversa, já que sentimos emoçóes, sensaçôes físicas como fome, dor, bem-estar. A combinação do perceber o mundo em torno de nós enquanto sentimos medo, frio, fome, alegria, saudade é um infinito exercício de percepção. Um olhar rápido e desatento, que ignora todas essas interferências, empobrece o entendimento.

Pessoas com deficiência visual podem romper os limites estabelecidos pela própria sociedade e conquistar o espaço que lhes pertence, embora a sociedade insista em vê-las com benevolência e até 
como dependentes e incapazes. Esse estranhamento dos cidadãos bloqueia a socialização e dificulta o relacionamento entre videntes e pessoas que não enxergam com os olhos. Obtêm-se com isso uma cidade subdividida entre videntes e deficientes visuais, uma maneira classificatória e injusta, que ignora características individuais e é capaz de estabelecer hierarquias e escalas de menor valor para pessoas com deficiência, em relação aos cidadãos sem deficiência aparente.

$\mathrm{O}$ uso que pessoas cegas fazem dos outros sentidos tem sido metodicamente estudado e compreende obras relevantes. Um exemplo é encontrado em Denis Diderot ${ }^{18}$ (1713-84), um dos maiores expoentes do iluminismo francês, editor da Enciclopédia. Em sua Carta sobre os cegos para uso dos que veem ele comenta: "Se alguma vez um filósofo cego e surdo de nascença fizer um homem à imitação do de Descartes, ouso assegurar-vos [...] que colocará a alma na ponta dos dedos; pois é dali que vêm as principais sensações e todos os conhecimentos”.

$\mathrm{O}$ autor nos mostra a maneira como uma pessoa supera os seus limites para ver o que não consegue enxergar e atingir a compreensão do inimaginável. Diderot cita o exemplo de Nicholas Saunderson (16821739), cego de nascimento e professor de matemática em Cambridge, onde ensinou teoria da visão, ótica, natureza da luz e das cores. $\mathrm{O}$ autor comenta que graças a essas superaçóes é que o homem consegue fugir da repetição do cotidiano para mergulhar num processo criativo que o levará a exceder os seus próprios limites.

\section{A proposta da pesquisa}

A proposta desta pesquisa é aprofundar o estudo da percepção da paisagem pelas pessoas que não enxergam com os olhos. Como o aprofundamento do estudo da percepção poderá nos propiciar o entendimento da apreensão que pessoas cegas têm da paisagem? Essa expertise, essa habilidade desenvolvida por essas pessoas, poderá ser aprendida por nós, videntes? Seremos capazes de perceber a paisagem de maneira mais intensa, life enhancing ${ }^{19}$ ? E, se capazes desta percepção, qual será o uso que dela faremos?

18 Sobre DIDEROT (1713-84): Nasceu em 1713, em Langres. Bacharel em Artes pela Universidade de Paris, em 1728. Em 1746 é contratado pelo editor Lebreton para traduzir a Cyclopaedia de Chambers. Um ano mais tarde é encarregado, com d'Alambert para dirigir a redação da Encyclopédie. Em 1749 é detido e encarcerado em Vincennes por causa da publicação de Lettre sur les aveugles (Carta sobre os cegos). A causa da detenção estaria, segundo a Sra. Vandeul, filha do célebre "enciclopedista", na reação de uma dama, ofendida em suas pretensóes científicas. Entretanto, as causas da detenção, ao que tudo indica, sáo bem mais sérias, e prendem-se à situação política e social da França de Luís XV. DIDEROT, Denis Obra I - Filosofia e Política. J. Guinsburg. Organização, Tradução e Notas. São Paulo : Perspectiva, 2000

19 Life-enhancing. Por volta de 1890, Bernard Berenson, aperfeiçoando uma noção advogada por Goethe de que um trabalho de arte deve ser "enriquecedor de vida", sugeriu que uma forma de se conseguir isto estaria nas mãos do artista que nos levaria a imaginar estarmos vivendo sensaçôes físicas genuínas diante de uma pintura ou escultura. Berenson denominou essas sensações de sensações ideadas (concebidas). 
Pessoas cegas poderão atuar como guias desse reconhecimento?

A interpretação de Os sentidos da paisagem aponta para o entendimento de que a pessoa cega não apenas está, mas ela existe na paisagem. Ela é, pertence e faz a paisagem, na medida em que vive nela e a resignifica. Ela é a paisagem em um sentido de pertença, de ligação com a construção da paisagem, atuando ativamente em sua criação. E não há uma paisagem para videntes e outra, diversa, para pessoas cegas. A paisagem é feita por todos nós que nela existimos, embora, dela, a percepção que todos temos seja diversa, peculiar. Na dimensão sensível de pessoas que não enxergam com os olhos os referenciais podem ser diversos, multifacetados; a cultura tem outras implicações, a percepção exige mais atenção nos sentidos.

Para que nos capacitemos a perceber a paisagem desta maneira tão rica, cabe a nós ("pobres de nós que trazemos a alma vestida" ${ }^{20}$ ) reaprender ("o estudo profundo, a aprendizagem de desaprender" ${ }^{21}$ ) a perceber a paisagem, a entendê-la em sua plenitude. Para tanto faz-se necessário abandonar os preconceitos, os rótulos, as teorias, para dar lugar aos novos significados.

"Ver é manter distância das coisas", reflete Tenberken"22. Manter distância da deficiência visual implica em tornar impossíveis o entendimento e as interaçôes sociais com essas pessoas. Como disse Lévi-Strauss, não há vida social sem reciprocidade; assim, torna-se imprescindível que a cidade e os cidadãos preparem-se para receber pessoas com deficiência visual, criando espaços amigáveis, mais do que apenas acessíveis, nos quais todos possam sentir-se bem-vindos, com direito ao entendimento da paisagem de maneira completa e independente. Para tal, é necessário que os cidadãos sejam capazes de um mínimo de compreensão das

Elas só existem na imaginação e são produzidas pelo trabalho de arte, que nos faz sentir sua realidade própria e viver sua vida. MONTAGU, Ashley. Tocar. 1986 p. 293. Pallasmaa reflete sobre a noção de life-enhancing lembrando a colocação de Berenson, que defendia que, quando experienciamos um trabalho de arte imaginamos um encontro físico real por meio de sensaçóes ideadas. Berenson teria denominado este fenômeno de tactile values (valores táteis). Nesse sentido, reflete Pallasmaa, um autêntico trabalho de arte simula as nossas sensaçóes ideadas de toque e essa simulação é life-enhancing (enriquecedora, realçadora, intensificadora de vida). Life-enhancing seria, portanto, a possibilidade uma experiência vivenciada quando os nossos sentidos estão em alerta, despertos, envolvidos em um profundo reconhecimento de si e do espaço. Pallasmaa sugere o envolvimento de textura, peso, densidade, materialidade e hapicticidade nesta experiência de percepção para se repensar um espaço que deveria ser construído de maneira mais sensual e intensa. Goethe creditava à arte a capacidade de intensificar a vida. Para o filósofo, vivenciar a arte de maneira intensa possibilitaria entender seus aspectos de maneira profunda e holística. Na arquitetura, Pallasmaa aponta que life-enhancing architecture deve fazer uso de todos os sentidos simultaneamente e fundir, unir a nossa imagem do eu com a nossa experiência do mundo. A incumbência mental essencial da arquitetura é a acomodação e a integração, reflete o arquiteto. A arquitetura articula as experiências de se estar no mundo e intensificar o nosso senso de realidade e do eu; assim, não estaremos habitando um mundo de meras fantasias. PALLASMAA, Juhani. The eyes of the skin, 2008, p. 11. Tradução minha.

20 PESSOA, Fernando. Obra Poética. São Paulo : Companhia José Aguilar Editora, 1972 : Poemas Completos de Alberto Caieiro. O guardador de rebanhos 1911-1912 :.IX p. 212

21 Idem, XXIV p.217

22 TENBERKEN, Sabriye. My path leads to Tibet. New York : Arcade Publishing, 2003. Tradução minha. Sabriye Tenberken é criadora da primeira escola de cegos do Tibete e co-fundadora da organizaçáo Braille without borders - http://www.braillewithoutborders.org 
$\because \because \quad \because \because \because \because \because \because \because: \quad \because \because \quad \because \because \because \because \because \because \because \because$

necessidades e talentos das pessoas cegas. Entender como se orientam, se organizam, e em seus percursos interagem com outros cidadãos, faz com que nós entendamos melhor a nossa própria maneira de viver em sociedade. Estamos de tal maneira habituados à visão que muitas vezes acabamos por desconsiderar outras maneiras de apreender o espaço. Mas a paisagem urbana não é composta apenas pelo que se vê.

Para o arquiteto Renzo Piano, a arquitetura é a arte de contar histórias. Reflito sobre as histórias que contariam as nossas cidades. Muito provavelmente, a maioria delas, histórias de exclusão, desigualdade e inacessibilidade. Nesse sentido, a convivência com pessoas que percebem de outras maneiras nos coloca diante de nós mesmos, nos faz questionar os nossos próprios valores. A interação com o diferente pode desenvolver a percepção e ainda colaborar na construção de um espaço social inclusivo que acolha pessoas com ou sem deficiências.

\section{Percebendo com o corpo todo}

\section{Vejo que nunca te disse como escuto música - apoio de leve a mão na eletrola e a máo vibra espraiando ondas pelo corpo todo: assim ouço a eletricidade da vibração, substrato último do domínio da realidade, e o mundo treme nas minhas mãos.}

Ao longo do desenvolvimento da pesquisa, em depoimentos e nas oficinas de percepção, protagonistas com deficiência visual teceram comentários, se manifestaram e deram indícios de que se pode perceber com o corpo todo. O conceito "perceber com o corpo todo" passou então a ser uma constante em meus pensamentos.

Realizei investigação minuciosa, cotejando obras de autores que refletem sobre a percepção. Reuni

23 LISPECTOR, Clarice. Água viva. São Paulo : Círculo do Livro, 1973, p. 10 
títulos de Merleau-Ponty ${ }^{24}$ para uma leitura acurada e crítica, o que propiciou um melhor entendimento do conceito. A filosofia tratou, durante muito tempo, a percepção como sensação. É de 1754 o Traité des Sensations $^{25}$, no qual Condillac discorre sobre a hipótese de uma estátua de mármore, da qual se abririam um a um os canais sensíveis. A estátua seria uma representação do ser humano ao nascer e a sucessiva aquisição dos sentidos. Para o autor, todos os conhecimentos viriam das sensaçóes.

Merleau-Ponty ponderou, em 1946, que as análises clássicas desconsideraram o fenômeno da percepção. Para o autor, a sensação era a experiência instantânea de algo externo a nós e se modelava pelo objeto percebido. Assim, a noçáo clássica de sensaçáo não era um conceito de reflexáo, mas um produto tardio do pensamento voltado para os objetos, que não dava espaço à interpretação, às interferências, estando pressuposta em todas as associaçóes.

A percepção, por sua vez, tem a função de inaugurar o conhecimento. Se nos ativermos aos fenômenos, notamos que a percepçáo precede a si mesma, ao invés de ser construída por associaçóes. Merleau-Ponty reflete sobre o significado das recordaçôes, da consciência, da atenção, apontando que a percepção é um juízo, é "o pensamento de perceber". O autor diz que "acreditamos saber muito bem o que é ler, ouvir, sentir, porque há muito tempo a percepção nos deu objetos coloridos e sonoros". Analisamos a percepção com a consciência, supomos em um só golpe, em nossa consciência das coisas, aquilo que sabemos estar nas coisas.

Assim, registra o autor, construímos a percepçáo com o percebido.

"E, como o próprio objeto percebido só é evidentemente acessível através da percepção, não compreendemos finalmente nem um nem outro". Dessa maneira, não temos a consciência do mundo por estarmos presos nele e é a nossa desatenção que torna os objetos ambíguos (MERLEAU-PONTY,1994, p. 27). O juízo é a diferença entre a sensação e a percepção e sentir, ao contrário, "é remeter-se à aparência sem procurar possuí-la ou saber a sua verdade" (MERLEAU-PONTY, 1994, p. 62).

Com o propósito de um aprofundamento ainda maior no entendimento da percepçáo, voltei-me para o psicólogo americano James J. Gibson (1904-1979), um dos mais importantes pesquisadores do

MERLEAU-PONTY, Maurice. Fenomenologia da percepção. São Paulo : Martins Fontes, 1994 Conversas - 1948. São Paulo : Martins Fontes, 2004

O visivel e o invisivel. Sao Paulo : Perspectiva, 1971

. O olho e o espirito. Sáo Paulo : Cosac \& Naify, 1960

A divida de Cézanne. São Paulo : Cosac \& Naify, 1960

A estrutura do comportamento. Belo Horizonte : Interlivros, 1975.

O primado da percepção. Campinas : Papirus, 1990. 


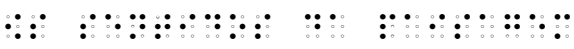

século XX no campo da percepção visual. Em obra originalmente publicada em 1958-5926, o autor defende que os sentidos não atuam de maneira isolada e passiva, como meros receptores de sensaçóes, mas sim como sistemas perceptivos de sentidos agressivos e solicitadores. Doze anos após a publicação de $A$ fenomenologia da percepção, o psicólogo demonstra concordar com o filósofo francês que a percepção não se dá por meio de sensaçóes isoladas e que percebemos com todo o corpo.

De acordo com Gibson (1966), os sentidos são canais de sensações e há dois significados para o verbo sentir: detectar algo e ter uma sensação. Quando os sentidos são considerados como sistemas perceptivos, o primeiro significado é usado. No segundo significado, "ter uma sensação", há uma vasta diferença entre sensação e percepção, desenvolvida em 1785 por Thomas Reid (Essays on the intelectual power of man II, p. 17). O sentimento que acompanha a percepção, chamamos de sensação. A percepção e a sua correspondente sensaçáo são produzidas ao mesmo tempo. Na nossa experiência, nunca as encontramos desconectadas. Os sentidos externos têm a capacidade de nos fazer sentir e perceber; fornecem variedade de sensações e ao mesmo tempo nos trazem a concepção e a crença na existência de objetos externos.

Gibson coloca que a percepção não pode ser extrassensorial, sem nenhum imput, e aponta como exemplo a detecção de obstáculos feita por pessoas cegas, o que é sentido como visão facial, mas na verdade é a detecção do eco feito pela audição. A pessoa cega "sente" a parede na sua frente sem realizar qual dos sentidos foi estimulado, ou seja, pode haver percepção sem sensação, mas não percepção sem informação. Nesse sentido, Merleau-Ponty também aponta que toda percepção é uma informação.

Pessoas cegas apontam obstáculos enquanto caminham explicando que percebem por um bloqueio do ar, do vento, mas raramente falam em detecção do eco feito pela audição ${ }^{27}$. Gibson defende que há dois níveis diferentes de sensibilidade e que os órgãos dos sentidos são de dois tipos:

receptores passivos - que respondem cada um a sua forma apropriada de energia.

receptores ativos - melhor chamados de sistemas, buscam a informação na energia do estímulo. Quando os sentidos são considerados canais de sensaçóes, pensa-se nos receptores passivos e nas energias que os estimulam, os elementos sensíveis dos olhos, ouvidos, nariz, boca e pele.

$\mathrm{Na}$ análise de Gibson, a percepção constante depende da habilidade do indivíduo detectar as

26 GIBSON, James J. The senses considered as perceptual systems. Boston, USA : Houghton Mifflin Company, 1966. Tradução minha.

27 Na California, Daniel Kish defendeu seu mestrado em Ecolocalização. Kish, ele próprio cego, desenvolveu desde criança essa habilidade que passa para outras pessoas cegas que procuram a instituição fundada por ele. O jornal O Estado de São Paulo, na edição de Domingo 3 de julho de 2011 publicou matéria sobre o fenômeno da ecolocalizaçáo, citando a experiência de Daniel Kish: Cegos usam técnica para 'ver' com audição. Ler mais sobre Kish no Capítulo 5. 
variações e que ele, ordinariamente, não presta atenção nas alteraçóes do fluxo dessas sensaçóes. Esta colocação nos remete a Merleau-Ponty: para se perceber realmente é necessário atenção constante e juízo; é preciso reaprender a ver o mundo; o objeto só se torna ambíguo por desatenção; a percepção é um juízo; olhar um objeto com atenção é vir a habitá-lo.

Seguindo com o estudo da percepção, a obra do arquiteto Pallasmaa $(2006,2008)$ contribuiu de maneira determinante para a pesquisa e elucidou muitos dos meus questionamentos. Informalmente, em 2009, traduzi grande parte de seus livros para o português ${ }^{28}$. Pallasmaa aponta que sentimos prazer e proteção quando o corpo descobre sua ressonância no espaço. Indica que a gravidade é medida pela planta dos pés e caminhar pode ser uma maneira de traçar a densidade e textura do solo.

A pele lê a textura, o peso, a densidade e a temperatura, detecta prazer e sofrimento, conta os anos da história. A cidade se desgasta com o tempo e o uso, degraus gastos conservam pregnância e contam sobre pessoas que passaram por ele. $\mathrm{O}$ tempo esculpe as formas nas construçóes, no reboco dos muros, corroendo grades de metal, gravando texturas no cimento das calçadas (PALLASMAA, 2008, p. 58). Segundo o arquiteto finlandês, materiais naturais como madeira, pedra, tijolo, permitem que o olhar penetre nas superfícies e as torna convincentes de sua veracidade; expressam sua idade e história, assim como a narrativa do seu nascimento e uso, adicionando a enriquecedora experiência do tempo ${ }^{29}$.

$\mathrm{O}$ autor pondera que a arquitetura se caracteriza pela modalidade dos sentidos que tende a enfatizar. Paralelamente à arquitetura predominante dos olhos há uma arquitetura háptica do músculo e da pele. Há uma arquitetura que também reconhece o campo da audição, do olfato e do paladar; aponta que toda experiência tátil na arquitetura é multissensorial e que qualidades de material, espaço e escala são medidas igualmente pelo olho, ouvido, nariz, pele, língua, esqueleto e músculo (PALLASMAA, 2006, p. 30).

Pallasmaa me levou ao conhecimento da arquitetura de Aalto, mostrando que o arquiteto está mais interessado no encontro do objeto com o corpo do usuário do que com a estética visual do próprio objeto - a arquitetura de Aalto exibe uma presença háptica e muscular. Incorpora deslocamento, encontro angular, irregularidades e polirrítmicos para despertar experiências corpóreas, musculares, e hápticas. Suas elaboradas texturas de superfícies e detalhes feitos à mão convidam ao sentido do tato e criam uma

28 A edição em português de The eyes of the skin, com o título Os olhos da pele foi lançada em 2011 pela Editora Bookman.

29 HOLL, Steven; PALLASMAA, Juhani; PÉREZ-GÓMES, Alberto. Questions of perceptions - phenomenology of architecture. San Francisco : William Stout Publishers, 2006, p. 29. Tradução minha. 
atmosfera de intimidade e cordialidade (PALLASMAA, 2008, p. 70).

Os projetos de Aalto para edifícios e mobiliário refletem sua preocupação com a arquitetura dos sentidos, de uma maneira que excede os limites da estética e privilegia o encontro dos materiais com o corpo, considerando o sentido háptico e o cinestésico. As construçóes de tijolos vermelhos estimulam o toque, os detalhes em madeira sugerem intimidade. $\mathrm{O}$ arquiteto trabalha por longos períodos buscando soluçôes que alternam diversos materiais e mostram sua preocupação com a arte. Os resultados, verdadeiras expressóes artísticas ${ }^{30}$ convidam pessoas a ouvir o ambiente, senti-lo em sua plenitude e por ele desenvolver afeto.

Também Rasmussen ${ }^{31}$ aponta os projetos de Aalto, citando o edifício projetado em 1948 para o Instituto de Tecnologia de Massachusetts (M.I.T.), em Cambridge. O edifício, denominado Baker House, funciona como um dormitório de estudantes que combina ambientes de estar com a privacidade dos quartos. Construído em linhas curvas, tem os espaços com dinâmicas e formas diferentes que alternam a vista das janelas para o Rio Charles e foi desenhado pensando na vida que seria vivida dentro dele (RASMUSSEN, 1986, p. 144).

Ainda Frampton ${ }^{32}$ descreve o prédio da prefeitura de Säynatsalo, também projetado por Aalto, em 1952, refletindo que as escadas que levam ao segundo andar são projetadas tanto em termos visuais quanto táteis. Paredes e degraus têm acabamento de tijolos vermelhos, frequentes nas construçóes do arquiteto. A cinestesia permite o entendimento do corpo ao subir a escadaria, enfrentando a fricção dos degraus de tijolos, e o contraste com o piso de madeira da sala do conselho. Nesta, o acabamento do local e sua função confirmam o seu status por meio do som, odor e textura, pondera Frampton.

Para Hall (1986, p. 65), "grande parte do sucesso arquitetônico de Frank Lloyd Wright liga-se ao fato de ele ter reconhecido a diversidade que caracteriza os indivíduos na sua experiência do espaço.” O autor cita o velho hotel imperial de Tóquio pelos estímulos sensoriais que ele propicia, como nas mudanças de níveis, na intimidade propiciada pelas escadas circulares, nas paredes de tijolos com textura que convidam ao toque do visitante. $\mathrm{O}$ autor cita também o talento dos antigos arquitetos japoneses na arte de projetar jardins, apontando que estes eram desenhados para ser vivenciados com um elevado número de sensaçóes, e não apenas com o sentido da visão.

30 BORRÀS, Maria Lluïsa. Arquitectura Finlandesa. Barcelona, Espanha : Ediciones Polígrafa S.A.

31 RASMUSSEN, Steen Eiler. Arquitetura vivenciada. São Paulo : Martins Fontes, 1986.

32 FRAMPTON, Kenneth. Toward a critical regionalism: six points for an architecture of resistance. In: FOSTER, Hal (editor) Postmodern culture. UK : Pluto Press, 1985, p.28 


\section{Outras contribuiçóes}

Dentre os autores que escrevem sobre os sentidos, destaco Constance Classen, no sentido do olfato; Donald Griffin, sobre a percepção de homens e morcegos; Daniel Kish, que trabalha com ecolocalização; Ashey Montago, autoridade em hapticidade e a edição de Michael Bull e Les Back: The auditory culture reader, da série Sensory Formations, da editora inglesa Berg. Em Modernity and the hegemony of vision, da mesma série, o editor David Michael Levin reúne contribuiçóes relevantes de autores, numa coleção de ensaios filosóficos que exploram o fato da cultura ocidental estar dominada pela visão como foco central para o conhecimento, a ética e o poder. Também Richard Sennet, em The conscience of the eye aborda a cultura centrada na visão e a vida social das metrópoles, em um passeio pela história de cidades como Atenas e New York.

Ainda dentro da filosofia, encontrei ${ }^{33}$ uma obra mencionada pelo neurologista Oliver Sacks em seu último livro $O$ olhar da mente. Trata-se da transcrição de cartas trocadas por dois filósofos ${ }^{34}$ nos anos 60. Magee, notório filósofo, professor de universidades como Yale e Oxford, vidente; Milligan, chefe de departamento da Faculdade de Filosofia de Leeds desde 1959, cego desde os dois anos de idade, falecido logo após aquele período. O conteúdo das cartas mostra como pessoas cegas são pouco consideradas, mesmo quando a sua performance extrapola os padróes comuns às pessoas de sua idade. Magee faz diversas perguntas e colocaçóes que deixam permear a percepção que muitas das pessoas videntes têm da cegueira, como, por exemplo, a deficiência sendo proibitiva para o desempenho da maioria das funçóes do cotidiano e um empecilho para a realização pessoal, profissional e afetiva.

Os dois filósofos discutem conceitos como a noção da cegueira, o conceito de luz e visão, o "enxergar" (este conceito foi brilhantemente desenvolvido por Wells, em The country of the blind, citado nesta pesquisa). Citam, em seus diálogos, os filósofos Aristóteles e Shoppenhauer, para quem a percepção não era apenas fonte de todo o conhecimento, mas o conhecimento por excelência (The world as will and representation, p. 77) $)^{35}$.

Milligan refuta a afirmação de Magee de que as pessoas preferem enxergar a qualquer outra coisa e aponta que muitos dos problemas das pessoas com deficiência visual são causados por viverem em um mundo opressivamente povoado por videntes e formatado por eles para a sua própria conveniência. $\mathrm{O}$

33 Muitos dos livros não editados no Brasil são facilmente encontrados em sebos ingleses e americanos, novos ou usados em ótimo estado, a preços excelentes. São enviados pelo correio no Registro Módico, que tem reduçáo tarifária e chegam em cinco semanas.

34 MAGEE, Bryan; MILLIGAN, Martin. On Blindness. New York : Oxford University Press, 1995. Tradução minha.

35 A obra tem uma bonita edição em capa dura traduzida por Jair Barboza para a língua portuguesa: SCHOPENHAUER, Arthur. O mundo como vontade e como representação. São Paulo : Editora UNESP, 2005. 


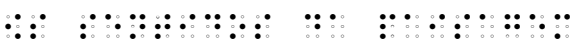

filósofo se ressente da discriminação, dizendo que pessoas cegas têm sido empurradas para os cantos, arrebanhadas em instituiçóes para cegos e cortadas fora da corrente da vida das sociedades, não pela sua cegueira, mas sim por decisão dos videntes.

Comenta que muitas das pessoas videntes que nunca tiveram contato com a cegueira ficam nervosas quando se defrontam com pessoas cegas. Encontro semelhanças nas colocaçóes do autor e nas experimentadas em oficinas realizadas durante a pesquisa. Videntes percebem cegos a partir de si, dos seus valores. Como para muitas dessas pessoas a visão é condição sine qua non de vida, perder a visão significa morrer. Se, no entanto, mudarmos o foco e passarmos a perceber as pessoas cegas pelas suas circunstâncias, lograremos melhores condiçóes para entendê-las

Não apenas os teóricos refletem sobre o tema da percepção abrangente. Pessoas afetadas pela deficiência visual são também autoras de textos relevantes. Há anos reúno títulos autobiográficos de pessoas que perderam a visão na vida adulta (cegueira adquirida), ou que nasceram com deficiência visual (cegueira congênita). As publicaçóes compreendem um longo período de tempo, o que propicia um entendimento abrangente e fornece indícios sobre a vida de pessoas cegas em outros contextos, em diferentes épocas e culturas. Nos autobiográficos, os títulos que consegui obter compreendem o período de 1903, com os livros de autoria de Helen Keller, até 2010, com a mais recente publicação do médico neurologista inglês Oliver Sacks. Este reúne relatos sobre deficiência visual, inclusive a do próprio autor. Um dos autores mencionados por Dr. Sacks é John Hull, catedrático do ensino religioso na Inglaterra, citado na pesquisa Os sentidos da Paisagem, na percepçáo do espaço.

As obras de autores que sofreram perda da visão dialogam com os depoimentos dos protagonistas da pesquisa. Uma dessas obras recentemente adquirida é o livro de Henry Grunwald ${ }^{36}$. O autor, que foi editor-chefe das publicaçóes Time e embaixador americano na Áustria, sofre de degeneração da mácula ${ }^{37}$, doença irreversível, frequentemente relacionada à velhice. Ele chama atenção para o grande

36 GRUNWALD, Henry. Twilight - losing sight gaining insight. New York : Knopf, 1999. Tradução minha.

37 A mácula é uma pequena área localizada na porção central da retina, responsável pela percepção de detalhes. "A degeneração macular relacionada à idade (DMRI) é conhecida como a cegueira do adulto no mundo industrializado, afetando mais de 1.75 milhóes de indivíduos nos Estados Unidos da América com aproximadamente 200.000 casos novos diagnosticados por ano. No Brasil, temos mais de 5 milhóes de casos diagnosticados e 100.000 casos novos diagnosticados por ano. A DMRI, juntamente com a catarata e retinopatia diabética, é uma das principais causas de cegueira legal em pessoas maiores de 50 anos, representando hoje a terceira maior causa de cegueira legal no mundo. A DMRI é uma doença progressiva da mácula que resulta em perda da visão central.” Fonte: Secretaria de Estado de Saúde do Distrito Federal. Subsecretaria de Atenção à Saúde. Diretoria de Assistência Especializada. Disponível em: www.saude.df.gov.br/sites/100/163/00006766.doc - acesso em 20/01/2012 
número de pessoas afetadas pelo problema e que frequentam as Lighthouse $e^{38}$ : mais de cinquenta por cento do total de inscritos.

$\mathrm{O}$ autor ressalta também que vemos sem enxergar e que ele próprio, conforme a doença progredia, recorda como tinha sido a experiência da visão normal e o que havia aprendido sobre ver e enxergar. Lembra-se que, quando as ferrovias começaram a se difundir no século XIX, muitos dos usuários reclamavam que a paisagem passava depressa demais e que assim se perdia o prazer das paisagens individuais. O olhar é reforçado pelos outros sentidos, diz ele: uma rosa tem aspecto diferente quando se pode cheirá-la, assim como um saláo de baile fica diferente quando se ouve a música.

Aponta que, por educação ou por falta de interesse, evitamos encarar as pessoas. As faces contam histórias e sabemos quando alguém está bravo ou alegre, mas não nos fixamos no que sinalizam essas emoçóes, na sua graduação ou intensidade; sobrancelhas franzidas, risadas, bocejos são óbvios, mas frequentemente perdemos a sinalização mais sutil: uma rápida compressão dos lábios, um desviar de olhar, o tremor da pálpebra, o franzir da testa.

Encontrei também obras que tratam da deficiência visual e de pessoas cegas, não editadas em português, das quais destaco a obra de Elisabeth Gitter, professora de inglês da City University do John Jay College, de New York, especializada em Era Victoriana. O livro, The imprisoned guest-Samuel Howe and Laura Bridgman, the original deaf-blind girl, trata da vida de Laura (citada na pesquisa Os sentidos da paisagem, no capítulo 2), uma menina de sete anos de idade, filha de fazendeiros de New Hampshire e do trabalho de Samuel Howe, diretor da Perkins Institution for the Blind, em Boston.

A menina surdacega, vítima de febre escarlatina, tornou-se referência e inspiração para intelectuais influentes em 1837, como Dickens e Carlyle. Em uma época em que pessoas surdacegas eram tratadas como idiotas, incapazes de entender e de sentir, cinquenta anos antes de Helen Keller, com a educação da Perkins School, Laura passou de uma espécie de tabula rasa de Locke para uma intelectual considerada, a primeira pessoa surdacega de quem se tem referência e que se desenvolveu a partir do aprendizado da linguagem tátil, braille, ${ }^{39}$ pouco conhecida na época.

É intrigante imaginar a realidade do início do século XIX, o preconceito, a ignorância completa

38 American Foundation for the Blind - a mais tradicional instituição norte-americana para cegos, com representaçōes em todo o país conhecidas como Lighthouse.

39 Louis Braille desenvolveu o método que começou a ser usado a partir do reinício das aulas do Instituto Nacional para Jovens cegos em outubro de 1824. Em 1829, foi lançada a primeira edição do Método de Palavras - escritas, músicas e cançóes por meio de sinais. A escrita braille continua a ser usada até hoje e é o único método para uma pessoa cega aprender a escrever corretamente as palavras. Imprescindível, náo pode ser substituída por qualquer outra modalidade de leitura, especialmente os arquivos de som. 
sobre a deficiência e compará-la ao progresso conseguido dois séculos depois. O avanço nos parece grande apenas quando não temos que lutar pessoalmente contra o estigma, a falta de condiçôes das escolas e das cidades e o despreparo da sociedade em lidar com pessoas diferentes. Mas, qual é a dimensão desse avanço? Como as nossas cidades se desenvolveram nesses 200 anos? Aprendemos a preparar os espaços de convivência para as interaçôes de pessoas com e sem deficiências aparentes? Abrimos reais possibilidades de crescimento profissional para pessoas que dependem de implementos específicos para desempenhar as mesmas funções que pessoas sem deficiência aparente desempenham? Propiciamos condiçóes de deslocamento de maneira independente e segura? Oferecemos abundância de textos transcritos para o braille?

Certamente, uma maneira de avançarmos nesse sentido é o aprendizado de perceber com todos os sentidos, reduzindo a hegemonia da visão. Frederick Franck ${ }^{40}$, referência nos meus estudos de desenho nos anos 70, já ponderava que olhamos de muitas maneiras, através de lentes, de microscópios, mas enxergamos cada vez menos. Apontava ele que rapidamente colocamos rótulos em tudo o que vemos e é através deles que passamos a enxergar a realidade. Olhar e enxergar, ambos envolvem percepção; mas quando olhamos o mundo e rotulamos os seus fenômenos, imediatamente fazemos escolhas: gostamos, desgostamos, aceitamos, rejeitamos, de acordo com a utilidade que aquilo tem para nós. O propósito de ver é sobreviver, cooperar, ver com vivacidade, intensidade e profundidade, da maneira como os chineses denominam "ver as dez mil coisas que existem ao meu redor".

$\mathrm{O}$ artista diz que desenhar é a disciplina pela qual constantemente se descobre o mundo. Aponta que o que ainda náo desenhou não viu e que quando começa a desenhar algo comum, se dá conta de como aquilo é incomum, extraordinário. Um completo milagre: a copa de uma árvore, ou a estrutura do pompom de sementes do dente-de-leão. Diz ainda que descobriu que, dentre as "dez mil coisas", não existe uma sequer que seja comum. E que todas elas merecem e são dignas de ser desenhadas. Eu completaria: e percebidas, da maneira fenomenológica proposta por Merleau-Ponty, pois, quando o artista se detém em um olhar atento e crítico, acontece a percepção.

\section{Base Teórica}

Os estudos que relacionam a arquitetura à deficiência visual encontram-se no âmbito da acessibilidade e do Desenho Universal. As pesquisas sobre deficiência visual, por sua vez, não costumam abordar a percepçáo do espaço. No tema da deficiência visual não foram encontrados estudos sobre a relaçáo que

40 FRANCK, Frederick. The zen of seeing - seeing and drawing as meditation. New York : Vintage Books, 1973. Tradução minha. 
pessoas cegas têm com a paisagem urbana, ou ainda a construção do espaço arquitetônico pelo enfoque da cegueira. Existe, sim, uma grande carência no estudo da relação da cegueira com a arquitetura e a paisagem, embora as pessoas cegas vivam na cidade, interajam com outros cidadáos e transformem os espaços em que vivem. Além de frequentemente desconsideradas como cidadãs, pessoas cegas não aparecem nos estudos acadêmicos da construção arquitetônica do espaço.

Esta pesquisa adota o conceito da paisagem como locus de experiência, vivência e interação. A pesquisa desenvolve-se no território urbano, espaço multifacetado da paisagem, cenário de partilhas e vivências que se desdobram em processos físicos, culturais e sociais, no sentido de que se referem às diversas percepçóes propiciadas pelos sentidos, combinadas às experiências de interaçóes físicas e orgânicas. Contribuem para esta conceituação os autores Sandeville ${ }^{41}$ (2004, 2004, 2005), Dansereau ${ }^{42}$ (1999), $\operatorname{Tuan}^{43}$ (1980, 1983), Meneses ${ }^{44}$ (2002), entre outros. Segundo Sandeville ${ }^{45}$, estudar a paisagem não significa descrevê-la em seus elementos e arranjos, mas sim reconhecê-la como universo de cultura e locus de experiências partilhadas. $\mathrm{O}$ autor entende a busca da paisagem como experiência e produção social, a partir de investigaçóes empíricas e de novos significados.

Com efeito, nesta pesquisa, compartilhar a paisagem com os participantes e entrevistados tem sido condição para o seu entendimento, para a experiência e revisão dos pressupostos e para a renovação dos conceitos. A sensibilidade das pessoas na vivência da paisagem ${ }^{46}$, condição sine qua non para o seu entendimento, pode sinalizar com uma reeducação para os sentidos, inclusive para o sentido da visão, condicionado que está por questóes culturais de implicaçóes diversas.

Dansereau (1999) trata da paisagem interior e exterior, da percepçáo do meio ambiente e das interferências feitas pelo homem, que distorcem e impactam o mundo que nos cerca e nos inclui. Tuan (1980) registra que "percepção, atitudes e valores preparam-nos, primeiramente, a conhecer a nós mes-

41 SANDEVILLE, Euler. Paisagens e métodos. Algumas contribuiçôes para a elaboração de roteiros de estudo da paisagem intraurban. In revista eletrônica da área Paisagem e Ambiente USP, 2004. Disponível em http://www.usp.br/fa/deprojeto/gdpa.

Um roteiro para estudo da paisagem intra-urbana 2004 In revista eletrônica da área Paisagem e Ambiente USP 2004. Disponível em http://www.usp.br/fa/deprojeto/gdpa.

42 DANSEREAU, Pierre Mackay. A terra dos homens e a paisagem interior Belém : NAEA/UFPA, 1999

43 TUAN, Yi - Fu. Topofilia. São Paulo : Difel, 1980. Espaço e lugar. São Paulo : Difel, 1983.

44 MENESES, Ulpiano Bezerra. A paisagem como fato cultural. In YÁZIGI, Eduardo (org). São Paulo : Contexto, 2002

45 SANDEVILLE, Euler. Paisagens e Métodos: algumas contribuições para elaboração de roteiros de estudos da paisagem intraurbana (1). In: Paisagens. FAU/USP, publicado em setembro, 2004

46 SANDEVILLE, Euler. Paisagem. Revista Paisagem e Ambiente no 20. São Paulo : FAU/USP, 2005 
mos" e aborda amplamente o uso dos sentidos na percepção. $\mathrm{O}$ autor aprofunda-se em cada um dos sentidos, colocando que estamos sempre em com-tato e que uma pessoa pode sobreviver sem a visão, mas não sem o tato - é preciso tocar para conhecer. Para Meneses (2002) a paisagem demanda a reunião de diversas áreas de estudo relacionadas às ciências exatas e humanas. $\mathrm{O}$ autor aponta que "a cidade constituiu um dos principais lugares da paisagem" e que esta só pode ser entendida por meio de critérios amplos e ricos como o da percepçáo.

$\mathrm{Na}$ minha contínua busca por autores que tratassem da percepção da paisagem para além do sentido da visão, encontrei referências em: Cullen (1978), Rasmussen (1986), Bloomer (1977), Aprobato Filho (2008), Yamaki (2001, 2008), Hillman 1993, Asmussen, Okamoto (1996), Lipai (1993), Rykwert (2004), Hall (1981) Yázigi (2000), Kish (2003) Santos (1985). Estes autores descrevem a paisagem e mostram suas peculiaridades de maneira rica e criativa, indicando como é possível e enriquecedor percebê-la de maneira plena.

Nenhum deles, no entanto, considera as pessoas cegas, aborda a percepção da paisagem a partir dessas pessoas ou relaciona o tema diretamente com a deficiência visual. As raríssimas citaçóes sobre a cegueira aparecem de maneira sutil, em poucas linhas do texto, ponderando sobre algum fato isolado. No entanto, mesmo sem mencionarem a deficiência visual, desenvolvem aspectos pontuais que se tornam recursos valiosos para cidadáos que não enxergam. Encontramos exemplos nas indicaçóes de Cullen ${ }^{47}$ que propóe recursos frequentemente usados na arquitetura como texturas, fechamentos e aberturas, pisos, noçóes como intimidade, cordialidade, aqui e ali, continuidade, perfumes, sons.

Rasmussen ${ }^{48}$ chama a atenção para a arquitetura que é percebida além do olhar e registra que o objetivo de sua obra é explicar qual é o instrumento que a arquitetura toca, mostrar a amplitude que ela tem, “despertar os sentidos para a sua música [...] e perceber as coisas que nos cercam”. Descreve o ritmo na arquitetura (RASMUSSEN, 1986, p.119), e aponta como "pessoas que vivem ao mesmo tempo em um país têm o mesmo senso de ritmo, movem-se de maneira semelhante, obtêm prazer com as mesmas experiências" (RASMUSSEN, 1986, p.127).

Sobre os sons produzidos durante as caminhadas, o autor mostra como as solas dos sapatos podem emitir sons e aponta que pessoas com deficiência visual estão constantemente alertas para esses sons, utilizando-se dessas mensagens para se organizarem espacialmente. A ponta da bengala faz ruído característico do rastreamento, servindo de alerta para a presença da pessoa cega e ao mesmo tempo orientando-a pela reverberação. Assim, é mais fácil caminhar junto a um muro ou uma parede, do que

47 CULLEN, Gordon. The concise townscape. Great Britain : W \& J Mackay Ltda, 1978

48 RASMUSSEN, Steen Eiler. Arquitetura vivenciada. São Paulo : Martins Fontes, 1986 
tentar se orientar em praça aberta. Essas experiências aparecem bem detalhadas nas oficinas e percursos acompanhados realizados no decorrer da pesquisa.

Bloomer ${ }^{49}$ apresenta sua obra como tendo sido composta para o ensino na escola de arquitetura de Yale University (1977, p. ix). Os autores relatam como, desde 1969, têm tratado a arquitetura pelo ponto de vista de como edifícios são experimentados, antes de se preocuparem como são construídos. Acreditam que os edifícios afetam emocionalmente indivíduos e comunidades e podem suprir pessoas com o sentido de alegria, identidade e lugar. Suas colocaçôes aplicam-se à pesquisa Os sentidos da paisagem em diversos pontos, inclusive na investigação de como pessoas cegas percebem o seu próprio corpo: por não enxergarem, pessoas cegas podem andar pelas ruas considerando que também não são percebidas.

$\mathrm{Na}$ obra de Aprobato Filho ${ }^{50}$, o professor Elias Saliba aponta que ganhamos muito, mas também perdemos muito com o surgimento das grandes metrópoles. A nossa paisagem auditiva deteriorou-se, a vida nas cidades perdeu qualidade e afundou em uma profusão de ruídos. Perdemos a sensibilidade para o ruído e, como atribuímos à audição apenas um papel auxiliar. O surgimento das metrópoles disseminou a "tirania do olhar", mas os olhos podem ser fechados, enquanto os ouvidos estão sempre abertos e prontos a captar sons de todas as direçóes (APROBATO FILHO, 2008, p. 13).

Hillman ${ }^{51}$ aponta que uma cidade é construída de relaçóes humanas e que caminhar pelas ruas deixando de lado a tirania do automóvel pode ser um interessante exercício. Passos podem vir sozinhos, acompanhados da bengala ou em companhia de outros passos e podem sugerir o roçar de corpos, o farfalhar do tecido. A paisagem mantém um constante diálogo com os nossos sentidos. (HILLMAN, 1993, p. 51)

A arquitetura de Erik Asmussen também mostra que construir a paisagem levando em conta recursos que possam enriquecer a percepção pode tornar o espaço mais agradável e as partilhas mais prazerosas. Nascido em 1913, na Dinamarca, Asmussen construiu mais de 100 edifícios na Escandinávia e Europa, o mais significativo deles localizado em Järna, na Suécia. O complexo, construído para um centro antroposófico inclui escola, clínica, centro cultural e artístico, fazenda e armazém de produtos naturais, moinho e padaria. $\mathrm{O}$ arquiteto desenhava para pessoas, trabalhando de maneira artística, visando um desenho orgânico capaz de criar ambientes de cura e bem-estar.

Coates, em artigo publicado pela The International Academy for Design and Health (Design \& Health) $)^{52}$ reflete sobre a arquitetura do arquiteto holandês que seguia os preceitos da antroposofia de

49 BLOOMER, Kent C e MOORE, Charles. Body, memory and Architecture. New Haven : Yale University Press, 1977

50 APROBATO FILHO, Nelson. Kaleidosfone.: as novas camadas sonoras da cidade de São Paulo. São Paulo : EDUSP : FAPESP, 2008

51 HILlMAN, James. Cidade \& Alma. São Paulo : Studio Nobel, 1993

52 COATES, Gary J. Seven principles of life-enhancing design - The architecture of Erick Asmussen. International Academy for 
Rudolf Steiner. Pondera como Asmussen considerava que até mesmo elementos como escada, colunas e mobiliário deveriam ter desenhos próprios e exemplifica: uma maçaneta, por exemplo, que terá a função de ser puxada, deve ser desenhada de maneira que os dedos possam envolvê-la completamente, enquanto que a usada para empurrar, deverá oferecer uma superfície ampla e generosa que receba a palma da mão de maneira prazerosa e sensual. Cita os sete princípios de life-enhancing que para ele são: unidade de forma e função; polaridade; metamorfose; harmonia com a natureza e o lugar; paredes (divisórias) vivas; luminosidade e perspectiva da cor; e o equilíbrio dinâmico da experiência espacial (tradução minha).

Okamoto $^{53}$ aponta que na cultura ocidental é comum tratar as questóes ambientais com objetividade e racionalidade. $\mathrm{O}$ resultado desse excesso de racionalização é que sentimento, emoção, afetividade caem para segundo plano (OKAMOTO, 1996, p. 9). Lipai ${ }^{54}$ constata que a arquitetura só poder ser percebida, vivenciada, compartilhada a partir do momento em que a obra está concluída e pergunta se apenas neste momento realmente temos condição de perceber e avaliar o projeto. Não seria possível desenvolver um método de conhecimento que permitisse que essa avaliação ocorresse na concepção do projeto, no momento em que se concebe a arquitetura?

Rykwert $^{55}$, historiador, professor na Universidade da Pensilvânia, indaga o que é necessário para criarmos cidades com melhores condiçóes de vida e que agradem mais aos seus habitantes. $\mathrm{O}$ autor pondera a respeito de cidades principais de vários países, cidades que cresceram fora de controle. Discute sucessos e fracassos de traçados urbanos, sugerindo como resgatar a qualidade das cidades, o sentido do lugar. Santos ${ }^{56}$ parte do pressuposto que aprofundar o conhecimento sobre as formas de apropriação dos espaços de uso coletivo corresponde a entender melhor os processos de desenvolvimento da cidade.

A antropologia também contribui para identificar a paisagem e as redes de sociabilidade de pessoas com deficiência visual na cidade, mesmo sem fazer referência direta à deficiência. Velho ${ }^{57}$ faz referência às pessoas que deixam sua cidade de origem e o ônus que isso acarreta. Com efeito, alguns dos protagonistas da pesquisa tiveram que deixar a cidade natal em busca de tratamento na metrópole. A mudança implica em deixar para trás uma rotina segura, o que para a pessoa com deficiência visual tem especial importância.

Design and Health. Disponível em http://74.125.47.132/search?q=cache:47kgF8VbFgwJ:www.designandhealth.com/edu_res/ Gary\%2520J.\%2520Coates\%2520p239.pdf+goethe+life-enhancing\&cd=8\&hl=pt-BR\&ct=clnk\&gl=br.

53 OKAMOTO, Jun. Percepção ambiental e comportamento. São Paulo : Plêiade, 1996

54 LIPAI, Alexandre Emilio. Arquitetura: percep̧̧óes de uso do espaço e suas múltiplas realidades. Tese de Doutorado - FAU/ USP 1993.

55 RYKWERT, Joseph. A sedução do lugar. São Paulo : Martins Fontes, 2004

56 SANTOS, Carlos Nelson F. (coord) Quando a rua vira casa. Sao Paulo : Ibam/finep, 1985.

57 VELHO, Gilberto. Individualismo e cultura. Rio de Janeiro : Zahar, 1999. 
Para Certeau ${ }^{58}$, os jogos dos passos moldam espaços, tecem os lugares. O autor mostra como os pedestres desenham caminhos confundindo os seus próprios com os caminhos da cidade. O não-lugar de Augé59 ${ }^{59}$, pode ser o ponto de encontro dentro da estação do metrô, local de espera por onde passam apressados os cidadãos sem registrar a presença da pessoa com deficiência visual à espera do funcionário que vai ao seu encontro. Bordieu ${ }^{60}$ também reflete sobre a cidade, a percepçáo e nossas condutas cotidianas.

Nos estudos da percepção encontrei referências em Montagu (1986), Classen (1996), Griffin (1959), Askerman (1992) e Schiffman(2005), entre outros. Schiffman ${ }^{61}$ descreve como a bengala de pessoas cegas auxilia no rastreamento do caminho a ser trilhado e fornece informaçóes sobre o espaço. A ponta da bengala não apenas rastreia a superfície, mas ao tocar o solo produz sons que geram ecos e estes funcionam como um elemento direcionador (SCHIFFMAN, 2005, p. 267). Na paisagem olfativa, Yamaki $^{62}$ (2001 e 2008) faz um inventário da paisagem de Londrina. Classen ${ }^{63}$ relata a história dos aromas das cidades, enquanto Ackerman ${ }^{64}$ elucida a história dos sentidos. Da série Sensory Formations, destaco: The smell culture reader ${ }^{65}$, The book of touch ${ }^{66}$, e The auditory culture reader ${ }^{67}$.

Diderot (2000), Condillac (1993) Bachelard (1993) contribuem na conceituação filosófica, com alguma citação sobre deficiência visual. Em Diderot (2000) vários exemplos são dados, com menção a diferentes pessoas cegas. Sobre o matemático Nicholas Saunderson ${ }^{68}$, por exemplo, Diderot registra: “[...] reconhecia os lugares onde fora introduzido uma vez pelo ruído das paredes e da calçada, quando o faziam, e cem outras coisas da mesma natureza que lhe eram comuns com quase todos os cegos". E sobre a Srta. Mélanie de Salignac ${ }^{69}$ :

\footnotetext{
58 CERTEAU, Michel. A invenção do cotidiano. São Paulo : Vozes, 1999

59 AUGÉ, Marc. Não-lugares: introdução a uma antropologia da supermodernidade. São Paulo : Papirus, 1994

60 BOURDIEU, Pierre. Coisas ditas. São Paulo : Editora Brasiliense, 2004

61 SCHIFFMAN, Harvey R. Sensação e percepção. Rio de Janeiro : LTC, 2005

62 YAMAKI, Humberto. Cheiros da cidade: Paisagem olfativa em: Quem tem medo do interior? Vol 1. Londrina : Editora UEL, 2001. Guia do Patrimônio Cultural de Londrina. Londrina : Humanidades, 2008

63 CLASSEN, Constance. Aroma. Rio de Janeiro : Zahar Editores, 1996

64 ACKERMAN, Diane Uma história natural dos sentidos. Rio de Janeiro : Bertrand Brasil, 1992

65 DROBNICK, Jim - editor. The smell culture reader. Oxford : Berg, 2006

66 CLASSEN, Constance - editor. The book of touch. Oxford : Berg, 2005

67 BULL, Michael; BACK, Les - editor. The auditory culture reader. Oxford : Berg, 2003

68 Sobre Nicholas SAUNDERSON (1682 - 1739) Cientista, matemático, cego, foi professor em Cambridge

69 Sobrinha de uma amiga e correspondente de Diderot
} 


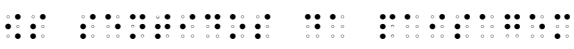

Se lhe serviam algo para beber, ela conhecia, pelo ruído do líquido que caía, quando seu copo estava bastante cheio [...] julgava, pela impressão do ar, do estado da atmosfera, se o tempo era nebuloso ou sereno, se caminhava em uma praça ou em uma rua, em uma rua ou em um beco, em um lugar aberto ou em um lugar fechado, em um amplo apartamento ou em um aposento estreito. Media o espaço circunscrito pelo rumor de seus pés ou pela repercussão de sua voz. Quando havia percorrido uma casa, a sua topografia permanecia-lhe na cabeça, a ponto de prevenir os outros sobre os pequenos perigos a que se expunham: tomai cuidado, dizia, aqui a porta é muito baixa, ali encontrareis um degrau. Notava na voz uma variedade que nos é desconhecida, e quando ouvia uma pessoa falar uma vez, era para sempre. (DIDEROT, 2000, p. 146)

Em Modernity and the hegemony of vision ${ }^{70}$, acadêmicos de universidades americanas e inglesas refletem sobre as questôes da cultura ocidental dominada por um padrão ocularcentric, examinando ideias no contexto da história da filosofia e considerando o caráter do discurso visual nos textos de Platão, Descartes, Hegel, Nietzsche, Husserl, Heidegger, Benjamin, Sartre, Merleau-Ponty, Levinas, Derrida, Foulcault. Gadamer, Wittgenstein e Habermas.

Há também referências em obras que auxiliam na compreensão dos problemas abordados na pesquisa. Sennett ${ }^{71}$ discorre sobre padróes visuais das cidades e a sua relação com as sociedades ocidentais. Botton $^{72}$ apresenta qualidades dos ambientes, numa jornada pela psicologia e filosofia da arquitetura e as conexóes com espaços e identidades. Na poesia de Pessoa (1967) e Woolf (1993); na literatura em

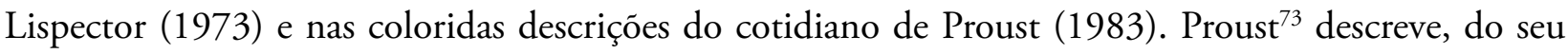
quarto, a percepçáo da paisagem externa: "Indagava comigo mesmo que horas seriam; ouvia o silvo dos trens que, ora mais, ora menos afastado e marcando as distâncias como o canto de um pássaro numa floresta, me descrevia extensão do campo deserto [...]" (PROUST, 1972, p. 11). Um intrigante conto do inglês H. G. Wells ${ }^{74}$ contribui com colocações pontuais sobre o estranhamento na convivência de

70 LEVIN, David Michael - editor. Modernity and the hegemony of vision. California : University of California Pres, 1993.

71 SENNETT, Richard. The conscience of the eye. New York : Norton, 1992

72 BOTTON, Alain de. The architecture of happiness. New York : Vintage, 2006

73 PROUST, Marcel. No caminho de Swann. Tradução de Mário Quintana. Porto Alegre : Editora Globo, 1972

74 WELLS, Herbert George. The short story: The country of the blind and others stories. London : Longmans, 1954. Publicado pela primeira vez em 1904 no Strand Magazine, e republicado em 1939 pela Golden Cockerel Press com o título The Country of the Blind and Other Stories 
pessoas videntes e cegas. Também contribuem diretamente no tema da deficiência visual, Saramago (1995), Sacks (1989,1995, 2010), Borges (1974).

Durante anos reuni obras autobiográficas de pessoas que perderam a visão, títulos que me trouxeram muito do que eu já vivenciava no meu contato com as pessoas cegas do Ponto a Ponto (Anexo II). Entre outros, cito Eames (1997), Keller (1996), Hull (1990 e 1997), Kish (2003), Kleege (1999), Kuusisto (1999) Lusseyran (1983) Queiróz (1986), Espínola Veiga (1946), Sá (2004), Grunwald (1999), Milligan (1995). Nesta última, há uma intensa reflexão sobre as questôes da vida com a perda do sentido da visão e a relação de pessoas cegas e videntes.

Autores com os quais me deparei ao longo da pesquisa acadêmica possibilitam um aprofundamento teórico ainda maior nas questóes da percepção, da sensibilidade, das formas como a paisagem pode ser percebida. Dentre eles destaco Pallasmaa (2006, 2008), Merleau-Ponty (1994) e Gibson (1966). Estes autores abriram frentes de investigação, trazendo novos referenciais nas questões da percepção da paisagem.

\section{Procedimentos metodológicos}

Devido à natureza multidisciplinar da pesquisa, fez-se necessário trabalhar com diversas áreas de conhecimento. O método eleito para o desenvolvimento deste trabalho apoiou-se em Bosi (1979 e 2003) e Rizzini (1999). Também Thiollent (2000) e Oliveira (1999) trabalham a metodologia e as condiçóes da captaçáo empírica de dados. Demo (2000), em Metodologia Qualitativa, aponta procedimentos para o desenvolvimento da pesquisa. As experiências vividas são importantes na questão da memória que estamos buscando resgatar e condicionaram a adoçáo de dois procedimentos principais: história oral, ou história de vida e realização de percursos induzidos.

$\mathrm{Na}$ história oral, a metodologia indicada por Bosi (2003) orientou a coleta, o tratamento e análise das histórias de vida. Embora desenvolvida com pessoas idosas, as indicaçóes da autora prestam-se perfeitamente à pesquisa com pessoas cegas. A história oral auxilia no entendimento da história de vida dessas pessoas, da deficiência, dos preconceitos, da interação cego e sociedade. Bosi (1979) aborda a construçáo da memória, a metodologia do registro dos relatos, o afeto e a história construída a partir do cotidiano. É de Bergson, citado por Bosi em Memória e Sociedade, a fenomenologia da lembrança e a experiência da percepção do meio "não há percepção que não esteja impregnada de lembranças". Durante o trabalho de campo realizei passeios de cunho etnográfico, onde fui ao mesmo tempo sujeito e objeto (BOSI, 2003): sujeito enquanto indagava, objeto enquanto registrava, ouvia sobre as memórias e percepçóes. 
Os percursos para observação da paisagem foram desenvolvidos em oficinas de percepção com recursos do método de passeios acompanhados ${ }^{75}$. A investigação desenvolveu pesquisa empírica combinada com trabalho teórico e de campo. O embasamento teórico apoiou a pesquisa direta com as pessoas cegas que tiveram o papel de guia da pesquisadora, esclarecendo, indicando, determinando os caminhos adotados e estabelecendo interaçóes entre os processos.

Os participantes foram selecionados aleatoriamente, dentro de um grupo heterogêneo de pessoas com deficiência visual. Ao optar por ouvir um pequeno grupo de pessoas cegas, tomei o cuidado de náo substituir representatividade por exemplaridade (DEMO, p.152). Para tanto, comparei, submeti a uma apreciação minuciosa as declaraçóes encontradas nos depoimentos, de maneira a me certificar de sua autenticidade. Encontrei nas falas dos sujeitos muito do que lia em autobiografias de pessoas com deficiência visual.

O método usado para a construção das fontes orais foi o da realização de entrevistas de natureza qualitativa, dentro de um método interpretativo, que implica uma interferência do pesquisador sobre a realidade a ser investigada, no sentido de que, tanto a investigação quanto os resultados alcançados, são influenciados pela visáo de mundo do próprio pesquisador. Com a relaçáo de confiança desenvolvida entre mim e os entrevistados, consegui a "soltura das ideias, a confiança da comunicação e o desembaraço da crítica” (DEMO, p.155).

Nos procedimentos para as entrevistas, as perguntas foram colocadas de maneira informal, individualmente e também em grupo e ao longo dos percursos e passeios. A pesquisa deu continuidade aos três tipos de entrevistas já utilizadas e apontadas por Rizzini: entrevista individual, entrevista com informantes, entrevistas em grupo. A partir de um roteiro previamente estabelecido, perguntei, observei e também participei ativamente, obtendo com isso desdobramento das respostas dadas pelos entrevistados. A participação do entrevistador permite aprofundar os comentários, trazendo à tona a emoção e a subjetividade do depoimento.

Os cenários para as entrevistas foram o interior das residências de pessoas cegas, lanchonetes e restaurantes da cidade de São Paulo, teatros, centros culturais, bibliotecas e galerias. As entrevistas com pessoas cegas tiveram papel importante na obtençáo de subsídios sobre a percepçáo da paisagem, na investigação dos sentidos que exercem papeis fundamentais para os deslocamentos e as emoçóes ali contidas.

Para os procedimentos nos passeios acompanhados e oficinas de percepção lembro que desde o início da pesquisa tenho convivido mais intensamente com os entrevistados, o que me permitiu um entendimento 
maior do universo da deficiência visual. Os trabalhos de campo se desenvolveram em diferentes regióes da cidade de São Paulo, incluindo ruas, avenidas, restaurantes e lanchonetes, além de passeios exploratórios por áreas verdes. Nos depoimentos das pessoas cegas surgiram igualmente questóes físicas da falta de condiçóes nos deslocamentos pela cidade e a sensação de não-pertencimento social, a sensação de não ser percebido ou considerado, em síntese, as questóes do expor-se e resguardar-se. Finalmente, mas não menos importante, constante durante todos os passeios foi a função do corpo como veículo de percepção.

O registro das falas foi feito com o uso de gravador portátil, e a transcrição posterior para arquivo Word. Os encontros, documentados com câmera fotográfica digital foram gravados em arquivos de imagem. Tanto as falas quanto as imagens foram registradas com o consentimento, por escrito, dos participantes. Para publicação, os trechos e imagens selecionados das entrevistas foram submetidos à aprovação de cada um dos protagonistas identificados.

\section{A deficiência visual}

O conhecimento adquirido sobre o tema é resultado do trabalho de pesquisa que reúne a experiência de 19 anos do projeto Ponto a Ponto e o aprofundamento do tema, desde 2005, no âmbito acadêmico. Durante esse período, pude perceber que pessoas cegas, pelo fato de prescindirem da visão, se utilizam de outras ferramentas, reunindo todos os sentidos para a apreensão do que acontece no seu entorno. Entendi que é de grande importância o uso dos sentidos, mas que há também um entendimento mais amplo, que Merleau-Ponty aponta como a percepção do corpo, em sua totalidade, e que cria conexóes entre os sentidos.

Neste trabalho, não indico que pessoas cegas sejam capazes de perceber a paisagem como o fazem as pessoas que enxergam. Muito pelo contrário, a deficiência visual tem os seus próprios códigos e signos, e maneiras peculiares de usá-los, recursos diferentes daqueles com os quais, videntes, contamos. Por fazerem parte do universo de uma minoria, mantêm-se restritos ao uso dessas pessoas. No entanto, pergunto-me: o estado de alerta aos comunicados do nosso próprio corpo, recurso usado pelas pessoas cegas, será capaz de propiciar aos videntes uma percepção mais rica e completa? A apropriação que pessoas cegas fazem da paisagem pode contribuir para agregar qualidades à paisagem existente? Perceber a paisagem de maneira mais abrangente, como fazem pessoas com deficiência visual, propicia o pleno uso do nosso potencial para entender o mundo, experimentando a vida de maneira mais intensa?

Merleau-Ponty pergunta: como ocorre a percepção? Se o mundo só se desdobra pouco a pouco enquanto o apreendemos por uma inspeçáo do espírito, entáo, como pudemos acreditar que víamos 


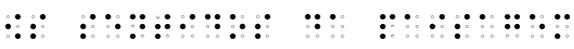

com nossos olhos? (1994, p. 281). Também Diderot (2000, p. 131) aponta “[...] que não basta que os objetos nos atinjam, que é mister ainda que estejamos atentos às suas impressóes; que, por conseguinte, nada se vê da primeira vez que nos servimos dos olhos; que somos afetados, nos primeiros instantes da visão, apenas por uma multidão de sensaçóes confusas que se desenredam somente com o tempo e pela reflexão habitual sobre o que se passa em nós [...]”. E ainda o romano Lucrécio, que há dois mil anos já refletia que os olhos não podem conhecer a natureza das coisas.

Quando vemos as torres quadradas de uma cidade, acontece muitas vezes de as percebermos redondas, visto que todo o ângulo percebido de longe parece obtuso ou até mesmo não se vê e perde o efeito, sem que aos nossos olhos chegue qualquer impressão. [...] $\mathrm{O}$ navio em que somos transportados move-se e parece estar parado; e aquele que fica no ancoradouro julgamos nós que avança. [...] a maior parte de tudo isso apenas nos engana por causa das opinióes de espírito que nós próprios juntamos, de maneira a fazer-nos ver aquilo que de fato os nossos sentidos não viram. (LUCRÉCIO, 1962, p. 130-132)

Refletir sobre a influência da percepção na qualidade de vida em ambientes externos ou internos é tarefa vasta e complexa. Este trabalho tenciona abrir caminhos para novos desdobramentos na percepção da paisagem, assim como também ir além das questóes usualmente investigadas no campo da deficiência visual, a maioria delas ligadas à cognição, educação, comportamento, inclusão e acessibilidade. A proposta desta pesquisa é aprofundar o entendimento da percepção das pessoas que não enxergam com os olhos, no sentido de indagar como as condiçóes do espaço urbano se apresentam e são percebidas por essas pessoas.

\section{O envolvimento com o tema}

O aprofundamento da investigação de como pessoas cegas percebem a paisagem urbana foi possível a partir do conhecimento adquirido durante 19 anos de convivência com pessoas cegas. Esse período teve início durante trabalho voluntário feito em audioteca no Rio de Janeiro ${ }^{76}$. O contato com as pessoas cegas usuárias da biblioteca, associado ao aprendizado do braille, deu início a uma série de atividades como a criação de um método de ensino a distância de braille, para cegos adultos.

O material, enviado usualmente por correspondência, me deu a oportunidade de adquirir maior desenvoltura na escrita braille, assim como também entrar em contato com a realidade das pessoas cegas que

76 CBL: Clube da Boa Leitura - Livros e leitura para pessoas cegas. Rua São Salvador, 56 - Laranjeiras - Rio de Janeiro / RJ 
vivem fora dos grandes centros, onde estão as instituiçóes de apoio. Os problemas de muitas dessas pessoas são inúmeros: dependência para locomoção, baixo poder aquisitivo, solidão, baixa autoestima e, sobretudo, dificuldade de adaptação a uma sociedade que não sabe exatamente como lidar com as deficiências.

O meu conhecimento na área da deficiência visual foi gradativamente se ampliando e surgiu então a idéia do Ponto a Ponto ${ }^{\odot}$, projeto criado por mim em 1994 e que organizou um banco de dados de pessoas cegas que passaram a se corresponder em braille. Em poucos anos, a iniciativa reuniu aproximadamente 400 pessoas de 40 países (Anexo2), o que possibilitou o recebimento e arquivamento de aproximadamente 3 mil cartas escritas (e respondidas por mim) em braille. Essas cartas me propiciaram náo só a intimidade com a escrita e leitura do braille, como também o conhecimento dos meandros da deficiência visual e de pessoas afetadas pela perda da visão. Cartas escritas em inglês, português e espanhol, que contém palavras formadas por pontos e encerram um universo de informaçóes, confidências, pedidos e relatos de pessoas cegas, compondo um arsenal de conhecimento sobre a deficiência.

Dentre os primeiros inscritos, surgiram pessoas com múltiplas deficiências, surdacegas. Para essas pessoas, passei a enviar artigos selecionados de jornais e revistas que transcrevia para o braille em máquina manual. Dessa iniciativa surgiu a idéia de editar um periódico em braille contendo artigos nas áreas de filosofia, literatura, artes, meio ambiente, saúde, gastronomia, turismo, negócios, comportamento, animais. Mais tarde, em 2007, o projeto "Boletim Ponto a Ponto" foi selecionado pela Petrobrás Cultural para patrocínio, juntamente com 263 outros participantes, dentre aproximadamente 8 mil projetos concorrentes de todo o Brasil.

A partir de setembro de 2008, teve início a primeira de 12 ediçôes do Boletim Ponto a Ponto. Com tiragem de 2 mil exemplares, o Boletim é impresso na gráfica da Fundação Dorina Nowill para Cegos e distribuído gratuitamente para pessoas cegas em todo o território nacional, assim como também para instituiçóes e bibliotecas públicas do Brasil, Portugal e África. Em 2009, o patrocínio foi renovado para a ediçáo do Boletim Ano II, como projeto convidado pela Petrobras Cultural, sem concorrer novamente à seleção pelos editais e mais 12 edições foram impressas e distribuídas.

\section{O desenvolvimento da pesquisa acadêmica}

No final de 2004, uma jornada de 2 mil horas em graduação de curta duração (2 anos) em Paisagismo, na Faculdade Anhembi Morumbi, apontou para a continuidade dos estudos da paisagem em curso de pós-graduação. Embora o trabalho desenvolvido até então com o projeto Ponto a Ponto não estivesse ligado à academia, a minha paixão pela pesquisa norteou este caminho.

A partir de 2005, já cursando, como aluna especial, disciplinas da pós-graduação da área de 
Paisagem e Ambiente da FAU/USP, tive oportunidade de aprofundar a pesquisa da paisagem no campo da percepção e inclusão da pessoa com deficiência visual. A pesquisa desenvolveu-se junto ao então Núcleo de Estudos da Paisagem (Paisagem, Cultura e Participação Social), sediado no Laboratório Espaço Público e Direito à Cidade - LABCIDADE, da Faculdade de Arquitetura e Urbanismo da Universidade de São Paulo - USP. O Laboratório, coordenado pelo professor Euler Sandeville Jr., me propiciou mais intimidade com o tema e com os meandros da pesquisa científica.

A convivência dentro do grupo de estudos facilitou o conhecimento de referências e conceitos, favoreceu o preparo metodológico da pesquisa, introduziu autores fundamentais no estudo da paisagem, resultando assim em uma ampliação do projeto inicial. As discussóes sobre paisagem com o grupo de estudos foram facilitadoras e a troca entre as diversas pesquisas favoreceu a abertura de novos caminhos. Durante esse período, tivemos a visita de professores de outras áreas de estudos que muito adicionaram nos procedimentos de metodologia e história oral, áreas pertinentes a todos os pesquisadores do grupo.

A convivência com pessoas cegas, somado ao embasamento teórico, permitiu eleger os caminhos que foram adotados na busca do entendimento da percepção da paisagem urbana pelas pessoas com deficiência visual. $\mathrm{O}$ ambiente acadêmico é instigador, a nossa rica biblioteca abre possibilidades para o desdobramento das pesquisas e a cada bibliografia é possível agregar novas vertentes de estudos.

Caminhei pela cidade e pelos parques com pessoas cegas, individualmente e em grupo; coletei dados, fiz entrevistas, ouvi testemunhos e relatos presencialmente e a distância. Participei de festas, apresentaçóes, formaturas, almoços, comemoraçóes, aniversários, passeatas. Fiz visitas às residências, aos locais de trabalho de pessoas com deficiência visual, conheci e conversei com professores, familiares e colegas de trabalho.

Presenciei aulas de mobilidade e reconhecimento do espaço e ensino do uso da bengala. Fiz palestras, participei de eventos, congressos, ofereci oficinas de percepção da paisagem para videntes que usaram vendas. Consegui publicaçóes não disponíveis no Brasil, adquiridas diretamente em sebos e livrarias no exterior, algumas delas esgotadas, de grande valia para a pesquisa. Como editora do Boletim Ponto a Ponto, leio e respondo diariamente inúmeras cartas em braille que recebo de leitores ${ }^{77}$, o que apesar de não ter ligação direta com o tema investigado, auxilia na composição da pesquisa.

77 Tenho arquivadas aproximadamente 4 mil cartas em braille recebidas de pessoas cegas do Brasil e do exterior, que foram respondidas também em braille. Aproximadamente 3 mil cartas foram escritas pelos participantes do Ponto a Ponto. Os leitores do Boletim Ponto a Ponto escreveram pouco mais de mil cartas no período de dois anos da publicação. 


\section{Os protagonistas}

Participaram da pesquisa pessoas que eu já conhecia e pessoas indicadas pelos próprios participantes. Foram entrevistados também frequentadores da Biblioteca Braille do Centro Cultural São Paulo, sendo que alguns deles preferiram manter o anonimato. A pesquisa contém também depoimentos de pessoas cegas, participantes do Ponto a Ponto, para quem escolhi um pseudônimo e que não estão registradas como protagonistas.

Ao iniciar a entrevista, os protagonistas tiveram a opção de escolher um pseudônimo. Alguns deles optaram por manter o seu próprio nome, outros preferiram um pseudônimo, mas voltaram ao assunto posteriormente, alterando sua decisão. Todos os identificados se prontificaram a posar para fotos, assinar um termo de consentimento para o uso do material na pesquisa e responderam as perguntas demonstrando prazer em participar. Quando denunciaram descaso, preconceito, falta de condiçóes adequadas na cidade, todos quiseram falar, fazer apartes nas observaçóes dos participantes, fizeram questão de ser ouvidos. Todo o material resultante das entrevistas e depoimentos (texto e imagem) foi submetido à apreciação dos protagonistas identificados, antes de ser anexado ao texto final desta pesquisa.

A pesquisa utilizou os três tipos de entrevistas, feitas individualmente ou em grupo: entrevista individual, entrevista com informantes e entrevistas em grupo. As entrevistas em grupo aconteceram durante eventos ou mesmo por ocasião de encontros casuais, como o acontecido na Biblioteca Braille do Centro Cultural São Paulo. Os informantes foram escolhidos pela proximidade e disponibilidade para participar com depoimentos, assim como também discutir as questóes da pesquisa em inúmeros encontros e conversas. Entrevistados individualmente foram os protagonistas que puderam dispor de algumas horas para um encontro previamente agendado. Os depoimentos e entrevistas, na íntegra, estão em “Trabalhos Programados”.

\section{São protagonistas:}
1. Juliana
2. Paulo
3. Sandra
4. Leninha
5. Daniel
6. Ronaldo
7. Roseli
8. Mario
9. Vicente 


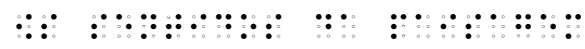

10. Toninho

11. Fernando (pseudônimo)

12. Angélica (pseudônimo)

13. Malú (pseudônimo)

14. Rubens

15. Alcides (pseudônimo)

16. Ricardo

17. Toni

18. Alexandre

19. Marlene

20. Hélio

\section{Entrevista individual:}

1. Juliana

2. Paulo

3. Sandra

4. Leninha

5. Daniel

6. Ronaldo

12. Rubens

13. Alcides

14. Ricardo

15. Tony

16. Alexandre

17. Marlene

18. Hélio

\section{Entrevistas em grupos:}

4. Leninha

5. Roseli

6. Mario 
$\begin{array}{ll}\text { 7. } & \text { Vicente } \\ \text { 8. } & \text { Toninho } \\ \text { 9. } & \text { Fernando } \\ \text { 10. } & \text { Malú } \\ \text { 11. } & \text { Angélica }\end{array}$

\section{Protagonistas Informantes:}

01. Juliana

02. Paulo

03. Sandra

\section{Juliana}

Em 1995, eu fazia trabalho voluntário na biblioteca de livros gravados para cegos no Rio, toda segunda-feira pela manhã. Em um desses dias chegou à biblioteca uma moça do Sul, querendo registrar uma leitora, sobrinha do seu namorado. $O$ registro foi feito em nome da Juliana. A emissária falou longamente sobre a menina, nascida com 6 meses e que perdeu a visáo na incubadora. Descreveu como ela corria pela casa para atender ao telefone, praticava esportes e era apaixonada pela leitura braille.

Eu acabara de criar o Ponto a Ponto. Logo lhe enviei a relaçáo de assinantes cadastrados e incentivei a jovem a participar. Com 18 anos na época, coincidentemente, ela é a inscrita de número 18 (de aproximadamente 400 inscritos). Passou a fazer amizades por carta com outros jovens e a me escrever frequentemente, relatando o seu cotidiano. Com uma enorme diferença de idade entre nós (ela tem a mesma idade da minha filha mais nova) acabamos por desenvolver uma sólida amizade, por carta e telefone, sem nunca termos nos encontrado nesses 19 anos. O tio casou-se com outra pessoa, já tem filhos e a nossa amizade criou laços.

Logo nos primeiros anos do projeto, 1995, 1996, passei a transcrever para braille artigos de jornais e revistas (história do projeto no Anexo 2) que enviava a título de empréstimo para alguns inscritos do Ponto a Ponto. Entre eles, a Juliana. Os artigos eram sempre devolvidos com comentários inteligentes e bastante maduros para uma jovem daquela idade. E foi assim que, ao ler um artigo de ciências, sobre o funcionamento do lado direito e esquerdo do cérebro, com o relato de uma pesquisa feita com sapos, ela comentou: não é que eu não me interesso por nada, não gosto de nada, é que eu náo sabia que essas coisas 


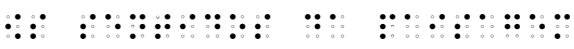

existiam. Mande mais artigos! A partir de então, fascinada com os assuntos de ciências Juliana decidiu ser bióloga. A sua professora, porém, logo se encarregou de frustrar os seus planos, dizendo que pessoas cegas não podem olhar em microscópio e, portanto, não podem estudar biologia ${ }^{78}$.

Um dos projetos que desenvolvi no final dos anos 90 para esta jovem diz respeito aos percursos que ela fazia em sua cidade. A partir de um mapa que me foi enviado por ela, e dos relatos sobre as suas saídas, desenvolvi um mapa tátil de $1 \mathrm{~m}^{2}$ subdividido em quatro partes, para tornar mais fácil o envio pelo correio. No mapa havia a indicação de sua casa e a partir dessa referência, a indicação de outros percursos. O material utilizado foi perfil de madeira colado sobre papel cartão, comum em maquetes de arquitetura. Os nomes das ruas e localidades estáo marcados em braille. Acompanhando o material, uma fita cassete gravada com as instruçóes, propiciava o entendimento do mapa de maneira independente.

Durante estes 19 anos, tenho aprendido com a Juliana a perceber de maneira diferente o que está ao meu redor. Em nossas conversas relatamos os fatos ocorridos nas famílias, acompanho o seu crescimento de estudante e os seus planos para a sua vida profissional. Jovem culta, apaixonada pela leitura braille, com grande facilidade para se expressar, é dona de rico vocabulário e está prestes a publicar o seu primeiro livro infantil. Com 34 anos, formada no curso de Letras em universidade do Sul, é uma protagonista informante, no sentido de esclarecer dúvidas sobre percepção, preconceito, aceitação da deficiência; são dela grande parte dos depoimentos poéticos que acentuam o sabor da leitura. Os depoimentos foram tomados pelo Skype e por telefone, tendo sido gravados e transcritos por mim.

\section{Paulo}

Conheci o Paulo em 2000, na USP, apresentado por pesquisadores que trabalhavam com projetos de educação. O psicólogo fazia pós-graduação e logo passamos a nos comunicar com frequência. Paulo tem uma retinopatia (doença degenerativa da retina) e teve perda progressiva de visão durante toda a sua juventude. Com processo irreversível, essa patologia leva à cegueira. Hoje, com 44 anos e visão residual para luminosidades intensas, Paulo acaba de defender o seu doutorado. Fez toda a pós-graduação passando pelo scanner página por página dos livros que leu, no

78 Cabe aqui lembrar a brilhante carreira do biólogo marinho Dr. Geerat J. Vermeij, professor do Departamento de Geologia da Universidade da California, que estimula os jovens estudantes cegos a se tornarem profissionais em Ciências Naturais, nas áreas de química, física, biologia. $\mathrm{O}$ cientista perdeu a visão com três anos de idade e desde criança interessou-se por conchas, colecionando e catalogando uma quantidade delas, com a ajuda da família. Mudando-se da Holanda para os Estados Unidos, estudou em Princeton e Yale. Fonte: National Center for Blind Youth in Science - Jernigan Institute.

http://www.blindscience.org/ncbys/vermeij.asp - Visitado em 13/05/2012 

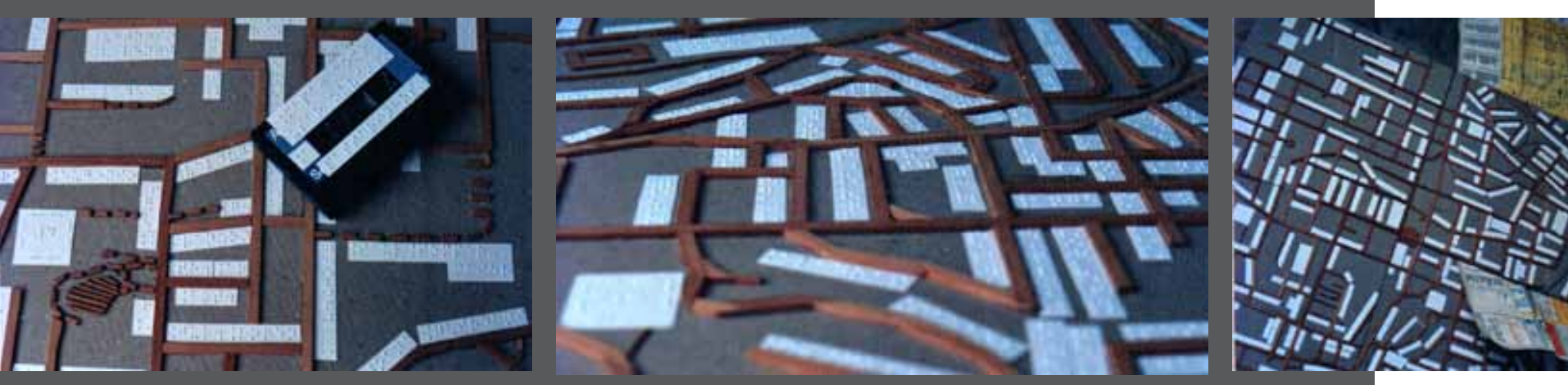

Mapa da cidade em relevo e braille.

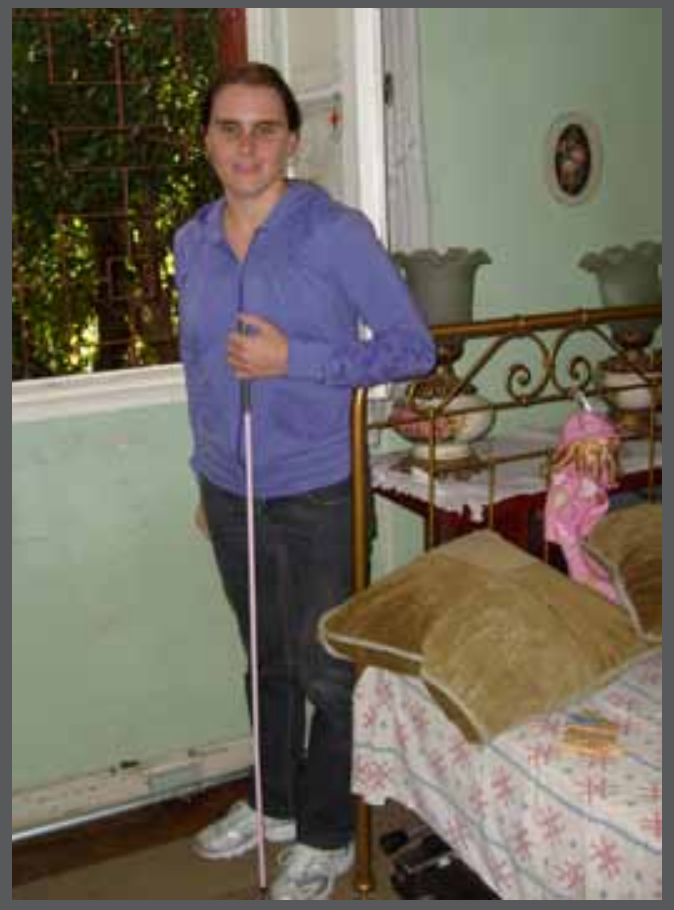

Juliana aos 32 anos

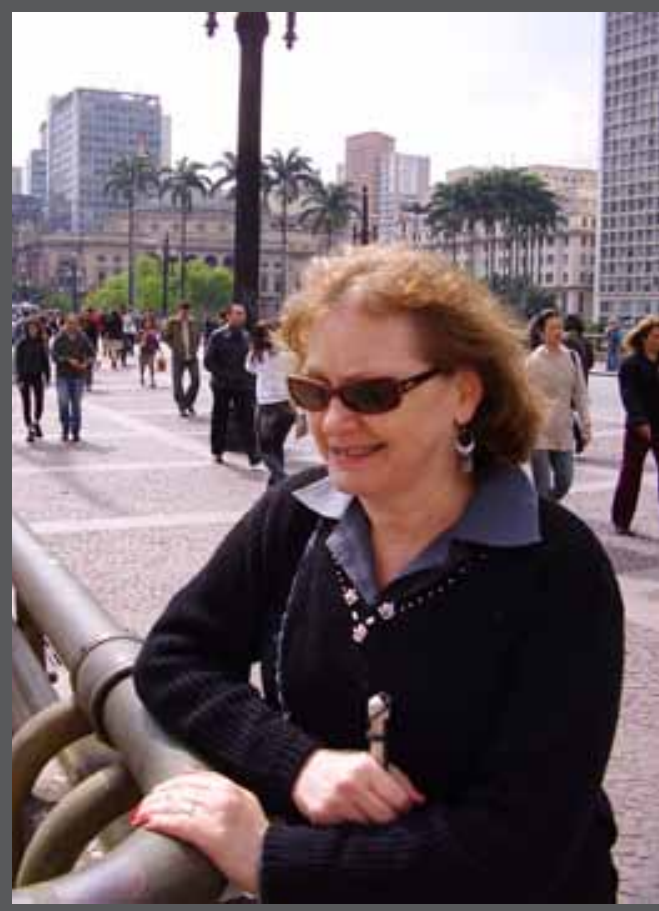

Sandra em passeio no centro de São Paulo 
sintetizador de voz que usa no computador. É respeitado conhecedor de Jean Piaget (1896 - 1980) e desenvolve um interessante projeto que aproveita maquetes de alunos de arquitetura para ensinar crianças cegas da rede pública de ensino. É informante por trazer as contribuiçóes de pessoa que já enxergou e teve que reestruturar a sua vida para conviver com a deficiência. Observador perspicaz, raciocínio rápido, conhecedor das reaçóes dos cidadãos videntes à cegueira, teve grande participação no desenvolvimento da pesquisa.

\section{Sandra}

Ao saber que um grupo de pessoas cegas se organizava para conhecer o Museu do Diálogo no Escuro, em Campinas, logo me interessei em participar. Acreditava que seria mais uma oportunidade para aprofundar os meus conhecimentos da deficiência visual e do universo das pessoas cegas. Foi o que realmente aconteceu. Quem estava organizando o passeio e me ligou para fazer o convite foi Sandra. Formada em Serviço Social, 61 anos, casada com um engenheiro que perdeu a visão na vida adulta, Sandra tem um filho e está aposentada. Tem ritmo de vida ativo e divide o seu tempo entre aulas de braille, como professora em uma instituição, e os cuidados com a casa e a família. Gosta de viajar, sair com amigos e ler. Conhece com detalhes a cidade onde cresceu e por onde sempre andou com desenvoltura.

Oriunda de família italiana da Mooca, cresceu com três irmãos que enxergam, correndo atrás de pipas pelos terrenos baldios do bairro, já com acentuada perda da visão. Aos 10 anos, com baixa visão, ia e voltava sozinha, de ônibus, da Mooca para o Colégio Caetano de Campos, onde estudava nos anos 60. Foi com Sandra o passeio acompanhado até o Colégio, onde aprendi sobre os trajetos dos ônibus, as texturas dos pisos, as adequaçóes e inadequaçóes da cidade, os odores, o afeto, a memória de menina observadora e sagaz. A protagonista contribui com a apresentação de outros amigos e elucidando dúvidas sobre deficiência e independência, uma "protagonista informante".

\section{Leninha}

Conheci a Leninha em 2001, em uma viagem de ônibus do interior do Estado para a Capital. Ela viajava desacompanhada, sentada ao meu lado. Tivemos oportunidade de conversar durante horas, o que abreviou o percurso e tornou a viagem mais agradável. Trocamos telefones e passamos algum tempo sem conviver. Retomamos o contato com a pesquisa, marcando os primeiros passeios acompanhados dentro de parques. Pedagoga aposentada, 64 anos, é casada e tem um filho de 26 anos. Divide o seu tempo com o tra- 


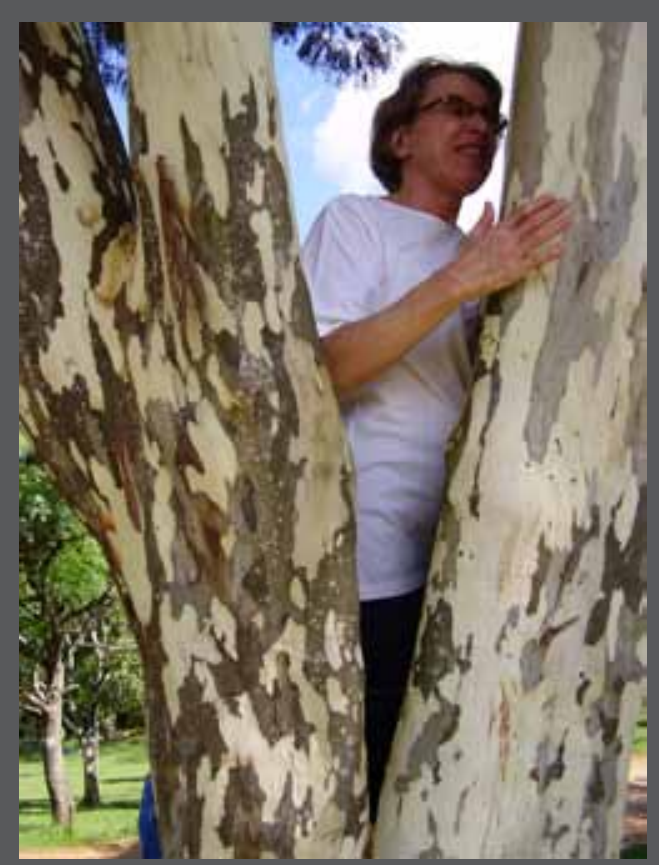

Leninha em árvore no Parque CEMUCAM

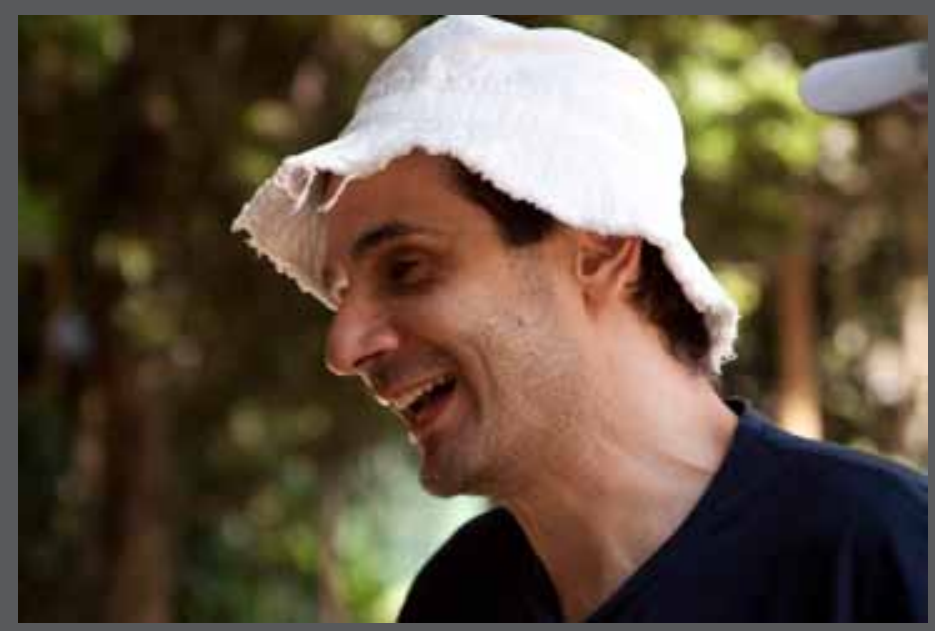

Paulo no Parque Trianon

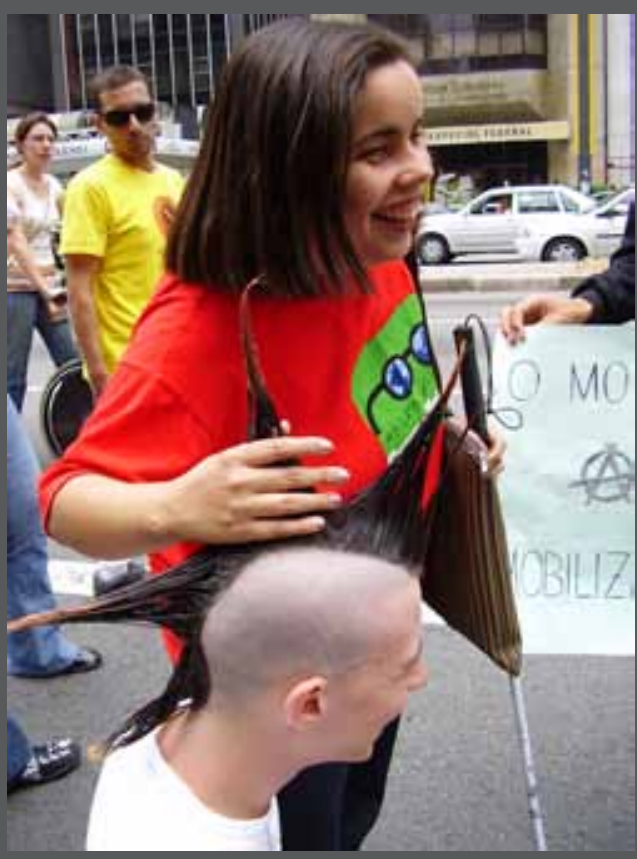

Roseli tateando pela primeira vez um penteado estilo Moycano de um rapaz Punk em passeata na Avenida Paulista em 13/11/2006

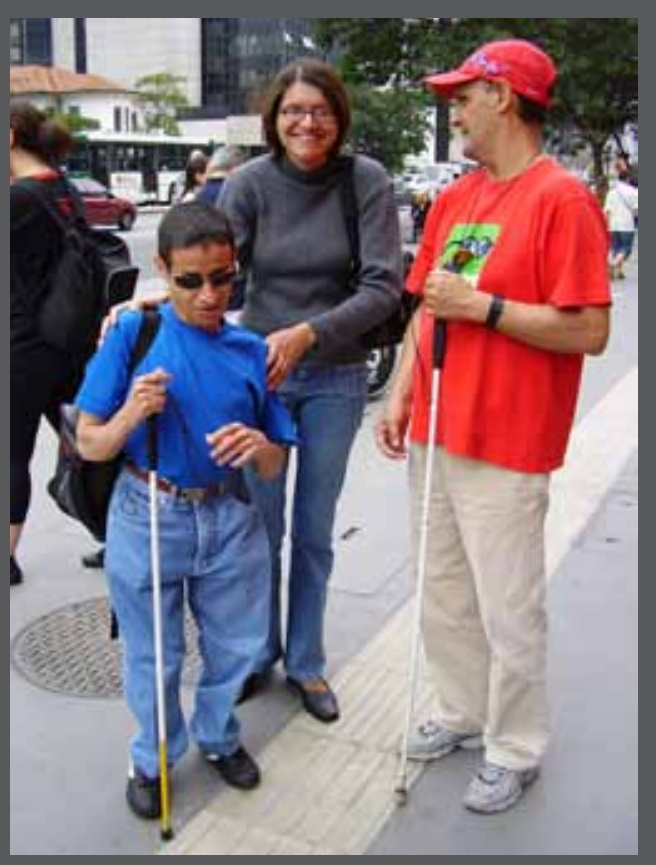

Vicente e Toninho em passeata na Avenida Paulista em 13/11/2006 


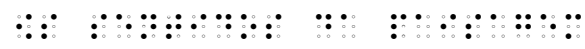

balho de dona de casa e atividades físicas como as caminhadas em parques. Defensora das causas das pessoas com deficiência visual, luta contra a discriminação e o preconceito com que são tratados. Teve grande participação no entendimento da percepção do espaço, em passeios acompanhados pelas ruas e parques da cidade.

\section{Roseli}

Indicada pela Leninha, Roseli é uma jovem solteira, com formação em Letras e Arte. É apaixonada pela leitura braille e faz parte do Grupo Mix Menestréis, que se apresenta regularmente no Teatro Dias Gomes, na Vila Mariana, São Paulo. Coordena um grupo de canto na sua igreja, mora com a família em cidade próxima a São Paulo e, em 2012, recebeu o título de Mestre em Educação, Arte e História da Cultura pela Universidade Mackenzie, onde trabalha. Apresentou-me outros protagonistas: Toninho, Mario e Vicente.

\section{Mario}

Radialista, 44 anos, solteiro, mora com a família em São Paulo. Funcionário da prefeitura, faz atendimento ao cidadão. Apaixonado por rádio, tem o hábito de ouvir programas e acompanhar a atuação dos radialistas. Define-se como uma pessoa introspectiva, muitas vezes acomodada e que gosta de cantar.

\section{Vicente}

José Vicente tem 54 anos, cresceu no interior e mudou-se para a capital, já adulto. Trabalha com compra e venda e também na defesa civil da cidade de São Paulo. É casado com Marilene, também cega, com quem tem uma filha. Questionador, diz que gosta de andar pela cidade para apontar tudo o que está de errado com ela. Participa de movimentos, passeatas, e acha que as pessoas com deficiência deveriam ser mais engajadas em suas reivindicações, "senão as coisas não mudam".

\section{Toninho}

Formado em Serviço Social, funcionário da prefeitura de Guarulhos, Toninho tem múltiplas deficiências. Mora com a mãe e o irmão, também cego, em São Miguel Paulista, mas planeja se mudar para São Paulo e iniciar uma nova graduação, desta vez em Faculdade de Direito, escolha que reflete uma vocação nata. Protagonista principal do Capítulo 4 - Preconceito, caminha com dificuldade e se ressente pela maneira como é tratado pelos cidadáos. 


\section{Fernando (pseudônimo)}

Conheci o Fernando no balcão da Biblioteca Braille do Centro Cultural São Paulo, na Estação Vergueiro do Metrô. Perguntei se poderíamos conversar, e ele disse que tinha tempo. Com sua permissão gravei a entrevista. Massoterapeuta em uma empresa, tem 27 anos e namora a Angélica (pseudônimo), com quem estava na biblioteca. Mora com a família em Guaianazes, para onde vai de trem. Participaram juntos da entrevista.

\section{Angélica (pseudônimo)}

Massoterapeuta, 25 anos, namorada do Fernando desde a véspera da entrevista. Trabalham na mesma empresa, um call center; Angélica tem um discreta perda de audição. Depois do dia da entrevista não tive mais contato com o casal.

\section{Malú (pseudônimo)}

Técnica em radiologia, 54 anos, trabalha no Hospital das Clínicas em São Paulo. Fizemos a entrevista no próprio espaço do Centro Cultural São Paulo, onde Malú estava para devolver e emprestar livros em braille. Cearense "de pouco estudo", cega congênita, mudou-se para a capital em busca de recursos e tratamento médico: "vim procurar o médico tarde demais e descobri que a minha deficiência não tinha jeito". Veio com uma irmá, com quem morou algum tempo. Após o casamento da irmã, preferiu morar sozinha. Reservada, os amigos desconhecem que mora só, pois não frequentam a sua casa. Deu um depoimento franco e aberto sobre seu trabalho, família, vida social. Quer manter o anonimato.

\section{Rubens}

Rubens deu um dos depoimentos mais emocionantes. Morador de Guaianazes, é casado e tem 41 anos. Era ajudante de pedreiro quando perdeu a visão por descolamento de retina. Adora a profissão, trabalhava com o tio o pai, já falecido. Todos se ressentiram da sua aposentadoria por invalidez. Foi alfabetizado em braille depois que ficou cego. Aprecia a leitura e há 17 anos frequenta a biblioteca braille, onde se encontra com um amigo. Gosta de sair para assistir shows com a mulher Solange, que não tem deficiências e conheceu por meio de um amigo comum. Rapaz muito simples e sincero era estudante, mas parou os estudos para trabalhar e no momento está desempregado. 


\section{Alcides (pseudônimo)}

Aposentado, casado e com 60 anos, trabalhava com o pai em São Paulo, onde cresceu. Há 24 anos teve descolamento de retina e perdeu a visão. Conta que com a perda da visão, perdeu também todos os amigos. Alcides acredita que os amigos se afastam das pessoas cegas porque náo sabem conviver com a falta da visão. Passou por um tempo de isolamento, deprimido, até que procurou outras pessoas com o mesmo problema "pois aí vai haver uma interaçáo dentro dos limites de cada um". Aprendeu a fazer bengalas de todos os tamanhos de PVC. "Compro o material e faço na minha bancada, tenho ferramentas e tudo. Compro o material sozinho." Usuário da Biblioteca Braille, toda semana passa para emprestar livros e vender seus produtos.

\section{Ricardo}

Bibliotecário, foi aluno do Colégio Caetano de Campos, já com perda acentuada da visão, nos anos 60. Graduou-se pela Faculdade de Sociologia e Política de São Paulo, FESP, em 1977. Casado, tem três filhos, é funcionário aposentado da prefeitura, trabalhando sempre em bibliotecas. Primeiramente na Biblioteca Monteiro Lobato, que tinha uma sala onde funcionava a seção de braille. Posteriormente, em 1986, a biblioteca foi transferida para o Centro Cultural São Paulo. Conhece todos os usuários, suas

preferências e hábitos. Músico, com CD gravado, estudou música na Escola Municipal de Música. Já teve um conjunto que se apresentava em bares. "Agora faço só eventos, shows, jantares, batizados, velórios (sorrisos). Já trabalhei muito na noite, indo de casa em casa, às vezes tocando em duas casas por noite. Agora não faço mais isso".

\section{Toni}

Toni é americana, trabalhou durante 18 anos em um hospital psiquiátrico e tem mestrado em Rehabilitation Counseling. Cega congênita, morou e trabalhou em New York. É viúva do antropólogo americano Ed Eames, professor universitário por 33 anos e $\mathrm{PhD}$ por Cornell University, que teve perda de visão perto dos seus 50 anos. Aposentada, reside na California, onde, com o marido, criou uma instituição formada por membros da comunidade, pessoas com e sem deficiência, que reúnem-se mensalmente para discutir políticas públicas de acessibilidade. $\mathrm{O}$ casal viajava por vários países dando palestras sobre a interação de pessoas com deficiência e animais, como cães-guias.

Correspondo-me com Tony há aproximadamente 17 anos, sem nunca termos estado juntas. $\mathrm{O}$ contato iniciou-se a partir da leitura de um artigo publicado na revista norte-americana Dog World. No texto, Toni con- 

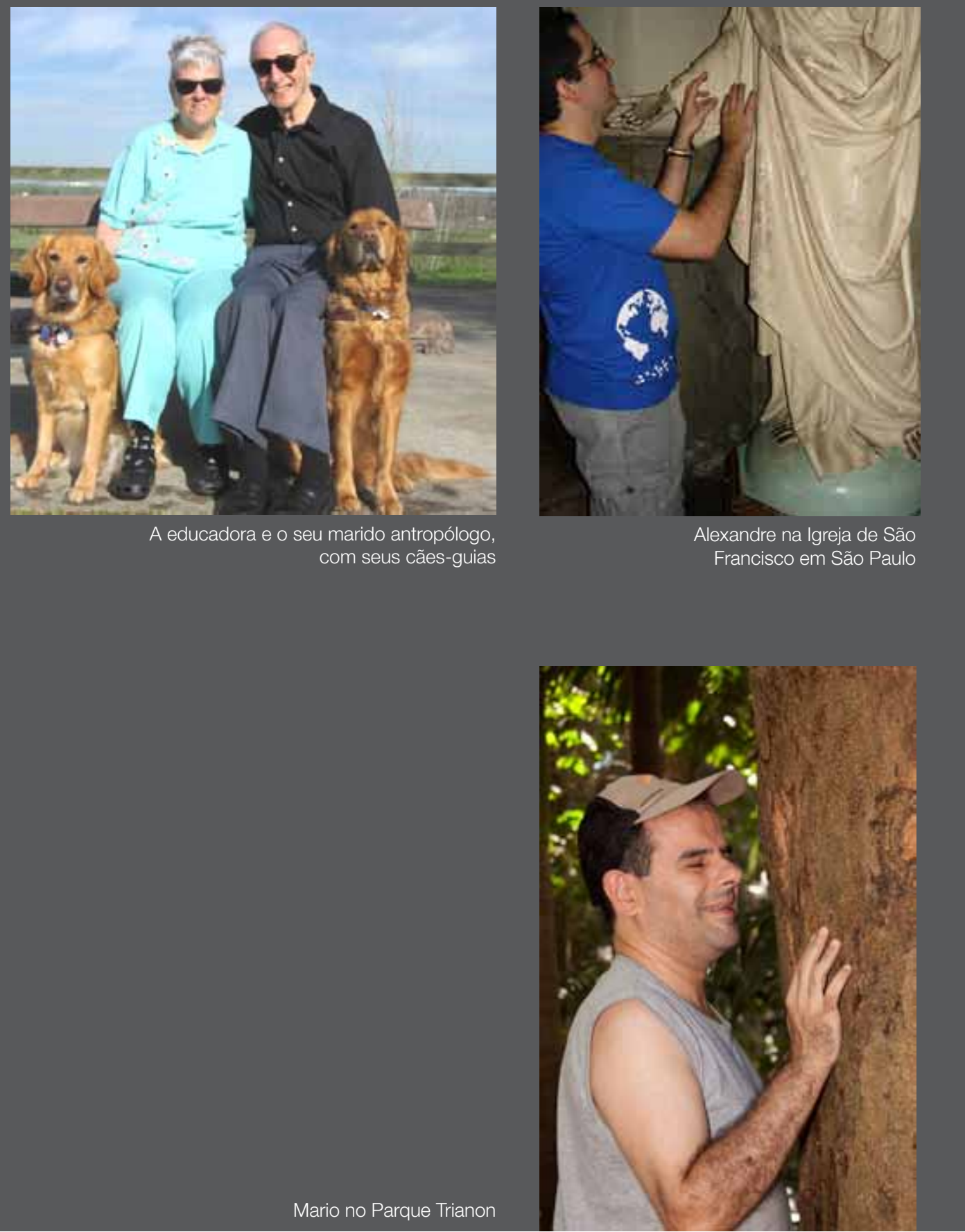
tava sobre o dia em que chamou a veterinária para fazer eutanásia em seu cão, que anos antes tinha sido eleito o cão-guia do ano naquele país. $\mathrm{O}$ artigo me emocionou e eu lhe escrevi uma carta em braille. A partir de então passamos a nos corresponder regularmente, a princípio em braille, posteriormente por e-mail. $\mathrm{O}$ casal tem livros publicados e era muito ativo na defesa das causas da deficiência. Com o falecimento do antropólogo, Toni continua o trabalho com outros profissionais e a ajuda dos amigos. Foi a única entrevista que recebi por escrito, em inglês, nesta pesquisa. Toni não fala português.

\section{Alexandre}

Analista de sistemas, funcionário de um banco, Alexandre é oriundo de família do interior e mora sozinho em São Paulo, em apartamento que alugou próximo ao metrô, na zona Sul. A entrevista foi feita durante um passeio em dezembro de 2007. Ficamos de marcar um segundo passeio, que ainda não aconteceu.

\section{Marlene e Hélio}

Conheci o casal, apresentado pela Sandra, de quem são amigos. Hélio foi operário da indústria automotiva, ambos são cegos e agora estão aposentados. Eu cursava a disciplina "PST 5807 - A memória das testemunhas", da Professora Ecléa Bosi e fui até a residência do casal, onde gravei a entrevista e fiz fotos. Os dados me foram extremamente úteis no trabalho de conclusão da disciplina: "Diário de Fábrica - operários cegos da indústria automotiva brasileira dos anos 60".

O casal mora há mais de 30 anos em uma vila no bairro do Ipiranga. Casa de impecável arrumação, clara, arejada, com mesa de centro na sala, decorada com fotos da família. Marlene levanta-se do sofá e com a mão estendida alcança sem titubear o porta-retratos do neto que me mostra, orgulhosa.

Na visita, li trechos do Diário de Fábrica de Simone Weil e repassei com Hélio os dados obtidos anteriormente, enquanto Marlene preparava café. Marlene é leitora atenta do Boletim Ponto a Ponto e apaixonada por filosofia. Helio tem excelente memória e dá instruçóes detalhadas de como chegar à sua casa, rua a rua, de maneira a se prescindir de guia para se encontrar o endereço. Conhece de cor a topografia dos arredores. Se quisermos saber como chegar a um local, devemos perguntar a uma pessoa cega: passei por subidas, descidas, curvas à direita e à esquerda, precisamente nos locais mencionados por ele. Depois da visita de três horas e de conversa muito agradável me despedi, com a promessa de retornar um dia. Sinto que fiz mais dois amigos. 


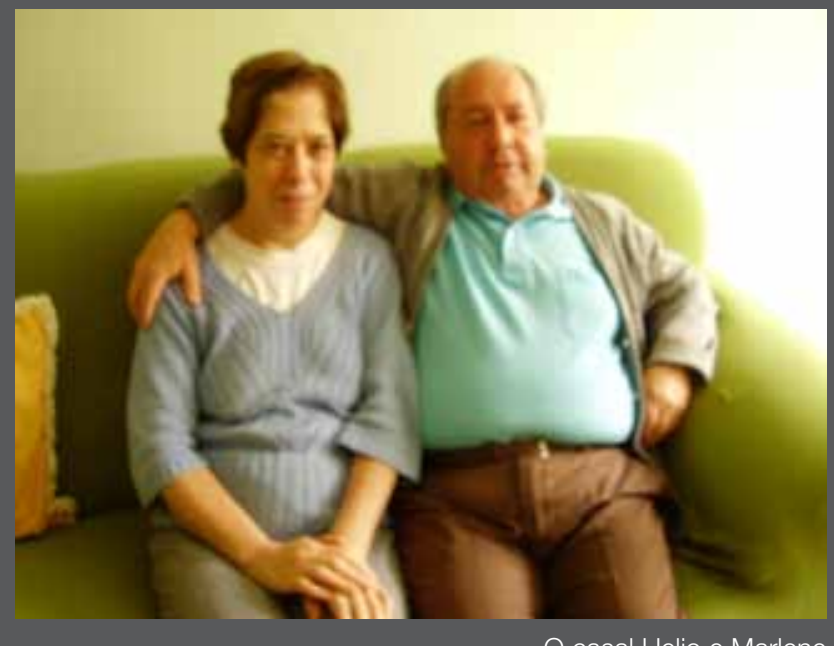

O casal Helio e Marlene
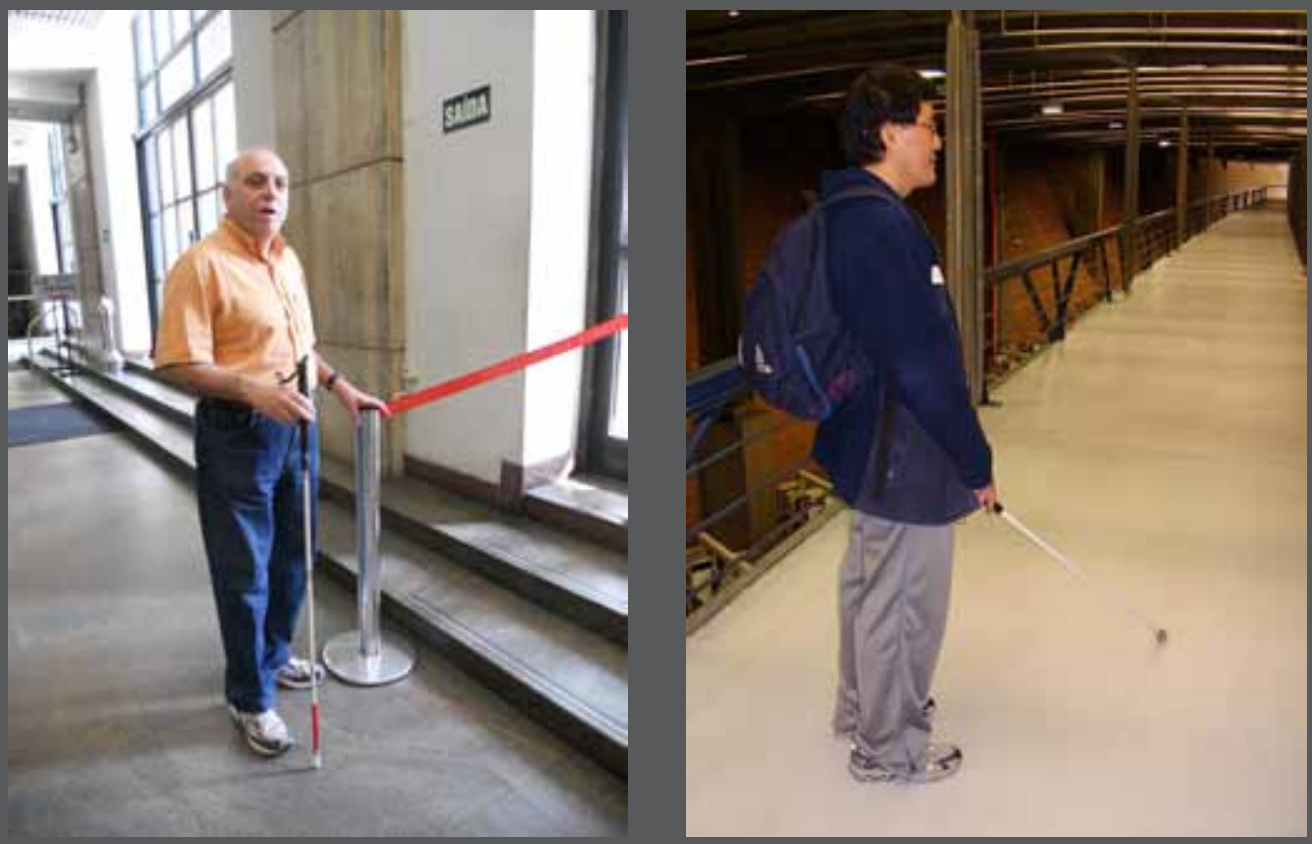

Ronaldo

Daniel 


\section{Daniel}

Descendente de orientais, com 49 anos, Daniel é engenheiro, casado, e tem duas filhas. Trabalha em um centro de pesquisas na USP e há pouco mais de dois anos recebeu o título de Mestre em Tecnologia Nuclear. Daniel tem má formação do aparelho ocular agravado pelo surgimento do glaucoma. Perdeu a visão há quatro anos, quando restavam 12 meses para encerrar o mestrado. Administrou com dificuldade o início da nova vida sem a visão, pois não conseguia atendimento nas instituiçóes de cegos para iniciar curso de orientação e mobilidade. Assim que conseguiu iniciar o aprendizado, inscreveu-se também em um curso de braille. Logo passou do exercício ao prazer da leitura e tornou-se assíduo frequentador da Biblioteca Braille do Centro Cultural São Paulo. Comenta que nunca leu tanto quanto agora, e nem com tanto prazer.

\section{Ronaldo}

Formado em Engenharia da Produção, é casado com Sandra, trabalha na Secretaria da Fazenda e tem um filho adulto. Ronaldo é responsável por um depoimento tocante, que relata a sua progressiva perda de visáo na juventude. $\mathrm{O}$ casal mora em um apartamento na Mooca, mobiliado com móveis antigos da família. 



\section{A CONTRIBUiÇÃo TEÓRICA SOBRE PAISAGEM}

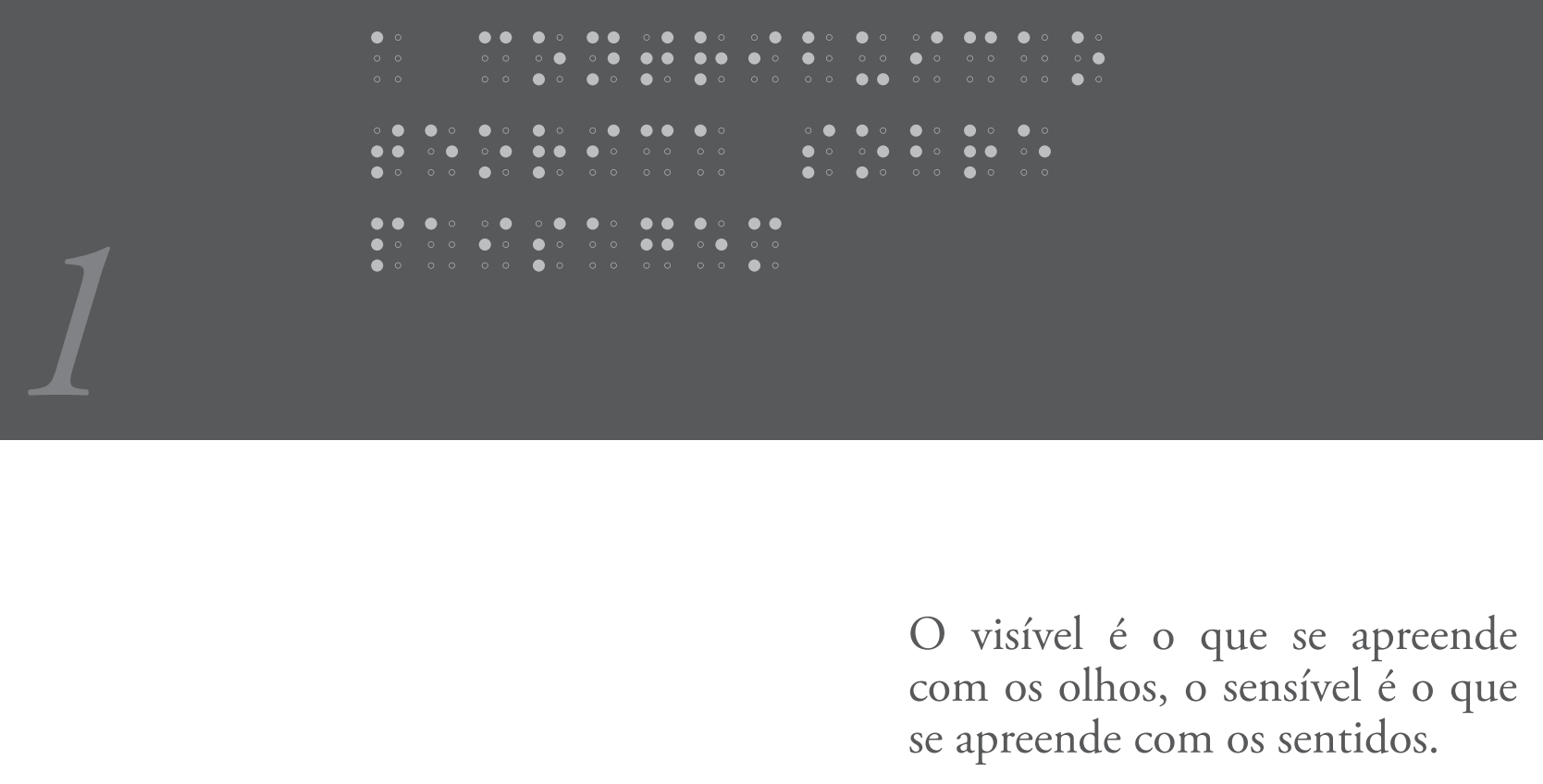

Merleau-Ponty ${ }^{1}$

A paisagem compóe o espaço no qual a sociedade compartilha experiências de prazer e conflito, encontro e desencontro, inclusão e exclusão, em uma dimensão histórica que reflete as vivências de seus habitantes. Locus em constante transformação, espaço de trocas e partilhas, construção e subjetividade, a paisagem é formada pelos seus aspectos físicos e pelas pessoas que a percebem, transformam e dela usufruem, em constante interação. A paisagem constituída de experiências e sensações inclui pessoas com deficiência visual, que em suas vivências já a percebem em sua morfologia, significados, conflitos, expressóes e interaçóes.

Este trabalho adota o conceito da paisagem como locus de experiência, vivência e interação. A pesquisa desenvolve-se no território urbano, espaço multifacetado da paisagem, cenário de vivências que se desdobram em processos físicos, culturais e sociais, no sentido de que se referem às diversas percepções propiciadas pelos sentidos, combinadas às experiências de interaçóes físicas e orgânicas. Con-

1 MERLEAU-PONTY, Maurice. Fenomenologia da percepção. São Paulo : Martins Fontes, 1994 p. 28 
tribuem para esta conceituação os autores Sandeville² (2004, 2004, 2005), Dansereau ${ }^{3}$ Tuan $^{4}$ (1980, 1983), Meneses 5 (2002), entre outros.

Sandeville (2004) possibilita o nosso entendimento de que "uma paisagem é uma realidade relacional em todos os sentidos e, por isso mesmo, sempre relativa. Depende da escala de observação, depende do enfoque privilegiado, depende das relaçóes reconhecidas, não só entre os objetos, mas entre as escalas em que sáo investigados". Segundo o autor, a paisagem implica em uma constante tensáo entre objetos pertencentes ao campo físico e as percepçôes que construímos a partir das nossas vivências. De maneira que estudar a paisagem não significa descrevê-la em seus elementos e arranjos, mas sim reconhecê-la como universo de cultura e locus de experiências partilhadas.

$\mathrm{O}$ autor entende a busca da paisagem como experiência e produção social, a partir de investigaçóes empíricas e de novos significados. Aponta que "depois que já se conhece a maçã, já se experimentou algumas vezes a fruta, uma simples exclamação - 'ah...a maçã’ ou - 'hum! maçã!' pode ser extremamente mais rica enquanto comunicação. A partir daí, é fácil estabelecer um diálogo, pois se apoia em uma experiência partilhada. Assim, árvores e maçãs são um misto daquilo que são enquanto um ser natural, e daquilo que imaginamos e conhecemos que sejam" (SANDEVILLE, 2004). O autor reflete que "são as pessoas que nos ajudam a ver a paisagem, nos ensinam a entendê-la e percebê-la".

Com efeito, nesta pesquisa, compartilhar a paisagem com os participantes e entrevistados foi condição para o seu entendimento, para a experiência e revisão dos pressupostos e para a renovação dos conceitos (as implicações de método desta pesquisa são tratadas em Consideraçôes sobre o método). A sensibilidade das pessoas na vivência da paisagem (SANDEVILLE, 2005), condição sine qua non para o seu entendimento, pode sinalizar com uma reeducaçáo para os sentidos, inclusive para o sentido da visão, condicionado que está por questôes culturais de implicaçóes diversas. Há também uma significação política que envolve a desigualdade, o preconceito, a descriminação. A pesquisa aponta para a necessidade de mudanças estruturais na forma de lidar com as diferenças, mudanças essas que dependem tanto da consciência quanto da ação política dos cidadãos.

Dansereau (1999) trata da paisagem interior e da paisagem exterior, da percepção do meio am-

2 SANDEVILLE, Euler. Paisagens e métodos. Algumas contribuições para a elaboração de roteiros de estudo da paisagem intra urban. In revista eletrônica da área Paisagem e Ambiente USP, 2004. Disponível em http://www.usp.br/fa/deprojeto/gdpa.

. Um roteiro para estudo da paisagem intra-urbana 2004 In revista eletrônica da área Paisagem e Ambiente USP 2004. Disponível em http://www.usp.br/fa/deprojeto/gdpa.

. Paisagem. Revista Paisagem e Ambiente no 20. São Paulo : FAU/USP, 2005

3 DANSEREAU, Pierre Mackay. A terra dos homens e a paisagem interior Belém : NAEA/UFPA, 1999.

4 TUAN, Yi - Fu. Topofilia. São Paulo : Difel, 1980. Espaço e lugar. São Paulo : Difel, 1983.

5 MENESES, Ulpiano Bezerra. A paisagem como fato cultural. In YÁZIGI, Eduardo (org). São Paulo : Contexto, 2002 
biente e das interferências feitas pelo homem, que distorcem e impactam o mundo que nos cerca e nos inclui. Percebo que as interferências de que trata o autor podem ocorrer nos âmbitos físico e social, sendo principalmente deste último que tratarei, considerando-se que o cidadão com deficiência visual, convive, interage e imprime em outros cidadãos as marcas de suas atitudes e comportamentos, recebendo deles também inúmeras influências. Os cidadãos agiriam como vasos comunicantes, contaminando-se com suas açôes, fundindo-se no social, redimensionando o cotidiano da cidade.

O autor (DANSEREAU, 1999, p.18) não cita a deficiência visual, mas se refere às qualidades sensórias da paisagem gelada, descrita pelos esquimós, às correntes de lava descritas pelos polinésios, à maneira como os índios Maoris brasileiros tratam plantas úteis e extraordinárias: "As múltiplas maneiras pelas quais esse conhecimento é adquirido implicam na vivacidade de todos os sentidos, não somente quanto à forma, o contorno, à cor da folhagem ou da plumagem, mas também quanto ao tato e ao sabor da casca, do fruto e da carne."

O autor aponta como as diversas percepçóes dos homens são codificadas. Nesse sentido, devo acordar com a sua colocação, pois me propondo a apresentar a maneira singular como pessoas com deficiência visual percebem a paisagem, o uso que fazem dela, as marcas que imprimem com suas açóes e os infinitos desdobramentos que a dinâmica das interaçôes sociais propiciam. Questiona (DANSEREAU, 1999, p. 48) "que tipo de programa nossa sociedade deveria inventar a fim de [...] alimentar a consciência do indivíduo? Como as percepçóes sensoriais da paisagem (a cidade poluída, o parque florido, o vilarejo verde, o país selvagem) podem ser aprofundadas por uma consciência aguçada [...]?”

Acrescento às questóes do autor as minhas próprias e reflito sobre o que seria necessário para os cidadãos adquirirem mais consciência da alteridade, agirem com menos estranhamento e adotarem atitudes de aceitação perante o diferente. Entendo que se a cidade recebesse com mais naturalidade a presença de pessoas com deficiência visual, essa partilha se traduziria em rico aprendizado para ambas as partes, quiçá lapidando a sociabilidade de pessoas com deficiência e sustentando a sua autoestima. Aos cidadãos sem deficiências aparentes, em contrapartida, seria oferecida a oportunidade de aprendizado e aprimoramento da consciência, além de novas e sutis maneiras de perceber a paisagem, combinadas a todos os desdobramentos que advém dessa ação.

Tuan (1980) registra que "percepção, atitudes e valores preparam-nos, primeiramente, a conhecer a nós mesmos". Aponta que sem esse conhecimento não podemos pleitear mudanças para o meio ambiente, já que elas envolvem diretamente o homem, elemento ativo nos problemas e nas mudanças. $\mathrm{O}$ autor aborda amplamente o uso dos sentidos na percepção, refletindo como "uma pessoa pode entrar no mundo da outra, apesar de diferenças de idade, temperamento e cultura”. Examina a percepçáo e os 
valores ambientais considerando as espécies, o grupo e o indivíduo; contempla as diferenças entre cultura e meio ambiente e topofilia e meio ambiente, com o objetivo de mostrar a contribuição que têm na formação de valores. Coloca que o odor pode evocar lembranças de cenas vividas e trazer à lembrança uma diversidade de sensaçôes: cheiro de flores e capim, terra úmida, que podem estar associadas a outras sensaçóes (sinestesia), como campos ondulando ao vento, a luminosidade, um estrada irregular.

Discordo, no entanto, do conceito que adota $(1980$, p. 7) de que a visão humana evoluiu no ambiente arbóreo. "No mundo denso e complexo de uma floresta tropical, ver bem é mais importante do que desenvolver um sentido agudo do olfato", registra o autor, apontando que com a evoluçáo os primatas adquiriram olhos grandes enquanto o nariz encolheu para permitir aos olhos uma visão desimpedida.

Acredito que em uma floresta densa, em que a extensão da visão encolhe consideravelmente, os sentidos todos devem estar constantemente em alerta, trabalhando em uníssono, para que se tenha a percepção da paisagem na sua complexão. Apoiando esta opinião, cito estudos de Classen (1996), Lewis ${ }^{6}$ e Hudson ${ }^{7}$. Classen (1996) comenta sobre a importância do cheiro na localização espacial em florestas tropicais. Os odores são abundantes no ambiente dessas florestas úmidas e densas, ao passo que a visão tem alcance restrito. Cita descrição que o antropólogo Lewis (1975) faz de uma floresta úmida da Nova Guiné:

Embora seja usualmente fácil caminhar pela floresta, não há perspectivas, panoramas abertos: um companheiro perde-se de vista entre folhas, galhos, sombras e troncos quando se afastou não mais que 20 metros. A luz é tênue e esverdeada. $\mathrm{O}$ ar é parado e tem cheiro de mofo. Ocasionalmente atravessa-se uma trilha de ar calmo levemente perfumado por alguma planta como a madressilva; passa-se por cheiros transitórios, de húmus, de madeira bolorenta apodrecendo ou de frutos caídos e pisados. (CLASSEN, 1996, p.110)

Esta citação despertou o meu interesse para os nativos das florestas densas, cuja consistência impede a visão para a orientação. Usariam eles as mesmas referências de orientação, como se cegos fossem? É intrigante a sensação de trilhar um caminho no qual tudo desaparece à frente em uma distância de apenas 20 metros. Pesquisando sobre outras experiências em florestas africanas, encontrei na obra de

6 LEWIS, G. Knowledge of Illness in a Sepik Society : A study of Gnau, New Guinea, Londres : Athlone Press, 1975 , p.46. In CLASSEN, Constance, 1996

7 HUDSON, W. Pictorial depth perception in sub-cultural groups in Africa. The Journal of Social Psychology, 1960,52 : 183-208 Citado por SERPELL, Robert. Influência da cultura no comportamento. Rio de Janeiro : Zahar Editores, 1997 
Serpell ${ }^{8}$ um estudo sobre nativos que descendiam de uma população que entrara na floresta de Knysna, no início do século XIX e desde então mantivera pouco contato com o mundo de fora da comunidade. $\mathrm{O}$ autor indica que:

Pode muito bem ser que o meio ambiente físico tenha promovido o desenvolvimento perceptual auditivo à custa da percepção visual. No sertão e na floresta, o ouvido era um melhor preditor de perigo do que o olho e assim, por um processo de percepção natural, a organizaçáo perceptual auditiva tornou-se mais característica de sua cultura que o desenvolvimento perceptual visual. Um aspecto de tais diferenças culturais qualitativas situa-se ao nível superficial da organização perceptual, ou seja, a percepção de profundidade do material pictórico. (SERPELL 1960, p.206-7).

Retomando Tuan (1980), o autor reflete sobre percepção, atitude, valor e visão do mundo, como conceitos chave do seu trabalho e coloca que topofilia é o elo afetivo entre a pessoa e o lugar. Faz referência à percepção dos bebês de oito semanas, indicando que são capazes de discriminar profundidade e orientação. Aponta que pessoas cegas congênitas que conseguem, por meio de cirurgia de catarata, recuperar a visão, têm dificuldade de reconhecer objetos e perceber a sua tridimensionalidade. Sobre este tema, Sacks ${ }^{9}$ publicou estudo aprofundado em livro que foi tema de filme ${ }^{10}$; no entanto, este assunto não será abordado nesta pesquisa.

$\mathrm{O}$ autor enfatiza a percepçáo da paisagem com o uso dos sentidos, aprofundando-se em cada um deles: discorre sobre o sentido do tato, colocando que estamos sempre em com-tato e que uma pessoa pode sobreviver sem a visão, mas não sem o tato - é preciso tocar para conhecer. Na audição (1980, p.10) indica que "somos mais sensibilizados pelo que ouvimos do que pelo que vemos: o som da chuva, o estrondo do trovão, o assobio do vento". Somos vulneráveis aos sons, tendemos a nos emocionar mais ao ouvir uma música do que ao observar um quadro. $\mathrm{O}$ autor coloca que o odor pode evocar lembranças de cenas vividas e trazer à lembrança uma diversidade de sensaçóes: cheiro de flores e capim, terra úmida, que podem estar associadas a outras sensaçóes, (sinestesia) como campos ondulando ao vento, uma

8 SERPELL, Robert. Influência da cultura no comportamento. Rio de Janeiro : Zahar Editores, 1977

9 SACKS, Oliver. Um antropólogo em Marte : sete histórias paradoxais. São Paulo : Companhia das Letras, 1995. Ver e não ver, p.123

10 No filme At First Sight (1999) a arquiteta Amy, interpretada por Mira Sorvino, se apaixona pelo massagista Virgil (Val Kilmer) que trabalha em Nova York. Entendendo que a visão do rapaz pode ser recuperada com uma cirurgia, ela o convence a se submeter à operação. No entanto, Virgil encontra grandes problemas em se adaptar à nova condição de vidente. At First Sight é dirigido por Irwin Winkler e baseado na história de Oliver Sacks To See and Not See 
luminosidade, uma estrada irregular. Em "perceber com todos os sentidos" o autor pondera que "ver não envolve profundamente as nossas emoçôes":

O mundo percebido através dos olhos é mais abstrato do que o conhecido por nós através dos outros sentidos. Os olhos exploram o campo visual [...] mas o gosto do limão, a textura de uma pele quente, e o som do farfalhar das folhas nos atingem como sensaçóes (TUAN, 1980, p.12).

Tuan discorre sobre a individualidade fisiológica (1980, p.53), citando diferenças visuais e auditivas. Cita poetas americanos cujos poemas versam sobre cidades: T. S. Eliot, Carl Sandburg, E. E. Cummings, Virginia Woolf (1980, p.58-59). Assim como Dansereau, reflete sobre a percepção dos esquimós (1980, p.89), que têm pelo menos 12 nomes diferentes para o vento. Em Topofilia (1980, p.107) descreve o conceito, colocando como os laços do homem com o meio ambiente podem se desenvolver, inclusive por meio do sentido do tato, o deleite do toque na água, na terra e no ar.

$\mathrm{O}$ autor indica que as crianças, mais do que os adultos, saboreiam com mais intensidade as sensaçôes produzidas pela natureza $(1980$, p.111) e que devemos aprender com as crianças ser mais complacentes e descuidados. Exemplifica de maneira deliciosa as sensaçóes: a cócega produzida por uma formiga subindo pela barriga da perna, o ruído da água sobre seixos, o canto das cigarras e o calor do chão. Em familiaridade e afeição (1980, p.114) o autor lembra que "a consciência do passado é um elemento importante no amor pelo lugar". Nesse sentido, lembro Bachelard ${ }^{11}$, sobre a casa, sobre o amor pelo lar.

Ao discorrer sobre as características do bairro urbano (1980, p.242), Tuan cita os contatos amistosos. Sobre o assunto encontramos farto material nos depoimentos dos protagonistas entrevistados, quando demonstram afeto pelo seu bairro. Há poucas demonstraçóes de conflito e estranhamento no bairro, sendo que nas proximidades da casa é que se encontram as atitudes amistosas dos moradores, segundo os entrevistados. Tuan coloca que a maioria das pessoas usa pouco a sua condição para perceber e que a cultura e o ambiente determinam quais os sentidos seráo privilegiados, apontando que o mundo moderno tende a privilegiar a visão em detrimento dos outros sentidos. Tuan é mais um dos autores que fazem considerações sobre a hegemonia da visão na vida moderna.

11 BACHELARD, Gaston. A poética do espaço. São Paulo : Martins Fontes, 1993.

Sobre este autor, ler mais no Capítulo 4 - O lado de dentro 
Em Espaço e Lugar (1983) Tuan aprofunda a perspectiva experimental na percepção da paisagem: "experiência é um termo que abrange as diferentes maneiras através das quais uma pessoa conhece e constrói a realidade" (1983, p.9). Assim, três anos após a publicação de Topofilia, o autor retoma a percepção da paisagem com o uso dos sentidos, abordando a experiência, o afeto, e o componente cultural da experiência. Na bibliografia do livro encontrei referências significativas para a pesquisa, como o trabalho de Révész ${ }^{12}$ publicado em 1937, do qual encontrei uma cópia em sala reservada da Biblioteca do Instituto de Psicologia da USP. As colocaçôes de Tuan, que sustentam a vivência da paisagem com o uso dos sentidos, contribuíram para a fundamentação, a definição dos conceitos e a formulação dos objetivos deste trabalho.

Para Meneses (2002) a paisagem demanda a reunião de diversas áreas de estudo relacionadas às ciências exatas e humanas. O autor aponta que "a cidade constituiu um dos principais lugares da paisagem" e que esta só pode ser entendida por meio de critérios amplos e ricos como o da percepção. E, segundo o autor, a percepção não pode ser entendida como um processo fisiológico, já que envolve pessoas e ambiente em constante mutação.

Relaciona a paisagem com a imagem (2002, p.34), apontando que "não há paisagem sem um observador", colocando que "percepção visual é condição fundamental para a existência cultural da paisagem" (2002, p.32). Ao mesmo tempo em que aponta a capacidade de visualização como condição fundamental para a percepção da paisagem, salienta que "a percepção envolve a organização e reorganização de dados a partir de mobilizaçóes, valores, aspiraçóes, interesses etc.". E ainda "indo além, envolve igualmente práticas que desfazem a antinomia sujeito/objeto, cultura/natureza” (2002, p.33).

No entanto, reflito, se a percepção envolve todos esses conceitos, incluindo as contradiçóes propostas por eles, certamente não pode estar confinada apenas à percepção visual. Expande-se, sim, por todos os campos do nosso corpo, como propóe a fenomenologia de Merleau-Ponty, de maneira tão abrangente a ponto de ultrapassar os limites da condição física para incluir os nossos referenciais culturais, nossa intuição, e a própria fruição da paisagem com as interações que ela propóe.

Meneses aborda a paisagem como fato cultural, como patrimônio ambiental urbano. "Como falar então de paisagem urbana? Certamente não para apenas duplicar o sentido de morfologia ou desenho urbano, ou espaço construído e semelhantes. É necessário mobilizar o enfoque de processo cultural e a presença de formas densas de apropriação cultural” (2002, p.38). Propóe a ampliação da paisagem, indo além da consideração do belo para o estético (2002, p.31), referindo-se ao universo “amplo, complexo e rico da percepção".

12 RÉVÉSZ, Géza. The problem of space with particular emphasis on specific sensory spaces. American Journal of Psychology, v.50, 1937, p.429-444. Edited by Karl M. Dallenbach. : Ithaca, New York, Morrill Hall : Cornell University, 1937. 
Nesse sentido, há que se perguntar como se dá a percepção das pessoas cegas? Como estabelecem teias de correlaçóes, como desenvolvem o afeto pelo lugar? Pessoas oriundas de outras regióes trazem os seus referenciais para a metrópole? Pessoas nascidas aqui são capazes de descrever a paisagem e suas relaçôes de temporalidade? Como se relacionam em seus percursos, como desenvolvem afeto em suas relaçóes sociais e como administram o estranhamento, as demonstraçóes de preconceito? Quais são os seus valores e expectativas? Essas e outras questóes serão abordadas e aprofundadas ao longo deste trabalho.

A antropologia também contribui para identificar a paisagem e as redes de sociabilidade de pessoas com deficiência visual na cidade, mesmo sem fazer referência direta à deficiência. Para melhor pensar a sociabilidade, pode-se observar os trajetos que pessoas cegas fazem pela cidade, assim como as condiçóes dos percursos e as interaçóes com a populaçáo; o lazer, a vida em família, em casa, as instituiçóes que prestam serviços às pessoas com deficiência visual, compóem igualmente a paisagem.

Velho $^{13}$ faz referência às pessoas que deixam sua cidade de origem e o ônus que isso acarreta. Se, por um lado, a perspectiva de explorar novas possibilidades pode ser promissora, segundo o autor, o processo não é indolor. Com efeito, alguns dos protagonistas da pesquisa tiveram que deixar a cidade natal em busca de tratamento na metrópole. Com isso, fez-se necessário repensar a paisagem anteriormente registrada na memória para assumir novos papeis e responsabilidades: aprender a reconhecer novos caminhos, construir novas redes de interação social, sair para trabalhar, almoçar sozinhos no trabalho e deixar para trás uma rotina segura, o que para a pessoa com deficiência visual tem um significado especial. Embora a partida tenha sido marcada por tristeza, as motivaçóes justificavam a mudança.

A chegada à capital implica em novas descobertas e estas envolvem a independência nos percursos, a capacidade de se locomover, a coragem de buscar novos caminhos e de se lançar no mundo desconhecido da metrópole. Pessoas com deficiência visual se deslocam usando transporte público, ou simplesmente caminhando, quando as distâncias o permitem. Certeau ${ }^{14}$ define o ato de caminhar como "um processo de apropriaçáo do sistema topográfico pelo pedestre [...] uma realização espacial do lugar [...] que implica contratos pragmáticos sob a forma de movimentos"(1999, p.177). "Os jogos dos passos moldam espaços. Tecem os lugares” (CERTEAU 1999, p.176) registra o autor, para mostrar como os pedestres desenham caminhos confundindo os seus próprios caminhos com os caminhos da cidade.

Mas nem só com passos é possível criar um tecido urbano. $\mathrm{O}$ transporte público abre rumos e direçóes. No Metrô, assim como também em toda a cidade, pessoas cegas se apropriam da paisagem:

13 VELHO, Gilberto. Individualismo e cultura. Rio de Janeiro : Zahar, 1999.

14 CERTEAU, Michel. A invenção do cotidiano. São Paulo : Vozes, 1999 
degraus, rampas, paineis e saliências, tornam-se referências para se localizar. Um exemplo de como vivenciam a paisagem em seus detalhes é o entorno do Centro Cultural São Paulo. O prédio é emoldurado por um canteiro e este por uma saliência de cimento. É guiando-se por ela que muitas das pessoas cegas se aproximam, deslizando a ponta da bengala desde a saída do Metrô até o Centro Cultural. Na chegada, sentem o vazio por onde passa o vento, ouvem as vozes que vêm de dentro, sentem a moldura do canteiro em ângulo, encontram o piso tátil: sabem por onde entrar.

Mas também vivenciam a paisagem de maneira diversa, como quando no Metrô, logo que passam pelo "bloqueio", param e esperam pelo funcionário. Aguardam em um lugar que, para essas pessoas, é um lugar de espera, denominado "logo depois do bloqueio". Esse local de espera, no entanto, é o não-lugar de Augé ${ }^{15}$, por onde passam apressados outros usuários sem registrar a presença da pessoa com deficiência visual, que se detém ali, próximo às catracas, aguardando o funcionário; cidadão que não identificam a existência daquele espaço amplo e vazio como ponto de espera e de encontro.

Bordieu $^{16}$ também reflete sobre a cidade e a percepção, e aponta que:

$\mathrm{Na}$ maior parte das condutas cotidianas somos guiados por esquemas práticos, princípios que impóem a ordem na ação, por esquemas informacionais. Trata-se de princípios de classificação, [...] tudo o que permite a cada um de nós distinguir coisas que outros confundem [...]. A percepção é essencialmente diacrítica; ela distingue a forma do fundo, o que é importante do que não é, o que é central do que é secundário, o que é atual do que é inatual. (BORDIEU, 1999, p. 99).

Nesse sentido, temos os depoimentos dos protagonistas da pesquisa e suas definiçôes do que é ou não prático, agradável, possível, difícil. Pedro ${ }^{17}, 40$ anos, perdeu a visão na juventude e manifesta o seu desagrado quando sai às compras:

Em shopping não gosto de ficar junto vendo vitrines, detesto. Antigamente suportava mais. Trombo quando é véspera de Natal, Dia das Mães, quando chove, é horrível. Não gosto de estar com a pessoa que vai escolher alguma coisa para ela. Anda, para,

15 AUGÉ, Marc. Não-lugares: introdução a uma antropologia da supermodernidade. São Paulo : Papirus, 1994

16 BOURDIEU, Pierre. Coisas ditas. São Paulo : Editora Brasiliense, 2004

17 Depoimento de pessoa com pseudônimo, que prefere não ser identificada. 
anda, para. Quando a pessoa está com humor para contar o que está vendo, pode até ser interessante. É melhor do que ficar em silêncio. No entanto, mesmo que não seja para mim, é interessante saber que hoje a moda é roupa rosa, ou roupas extravagantes. Alguns tipos de comércio dá para perceber pelo cheiro, borracharia, padaria, perfumes. Você passa em frente à loja de sabonetes e cosméticos, tem aquele cheiro gostoso, eles borrifam perto da porta para todos ficarem com vontade de comprar... A rua, o vento e poluiçấo podem levar embora o cheiro da loja, ou não, depende de como a loja coloca as coisas na vitrine, acho que loja chique não gosta mais de colocar empilhado, sem o vidro. Agora está tudo atrás dos vidros.

Ao contrário do que parece entender grande parte da população, pessoas com deficiência visual não são todas iguais. Cada ser carrega em si um universo de peculiaridades, a começar pelas próprias características da deficiência, tão amplas e diversas. Mas a paisagem é de todos, a cidade é de todos, e são todos que a fazem existir em suas características e diversidade.

\section{Este trabalho versa sobre as novas formas de vivenciar a paisagem, sobre outras possibilidades, inclusive a construçáo de uma relação diversa e mais harmoniosa entre cidadãos videntes e cidadãos que não enxergam com os olhos. A paisagem não é apenas o que se vê.}

No século XVIII, Diderot (2000) refletia sobre como o entendimento da deficiência visual poderia ser proveitoso para nós, videntes:

[...] caso se olhasse o fato mais de perto, verificar-se-ia, creio, que se pode realmente aproveitar outro tanto para a filosofia questionando um cego de bom senso. Saber-se-ia como as coisas se passam com ele, poder-se-ia compará-las com a maneira pela qual elas se passam em nós, tirar-se-ia talvez desta comparação a solução das dificuldades que tornam a teoria da visão e dos sentidos táo confusa e tão incerta. (DIDEROT, 2000, p.124) 
Para as pessoas com deficiência visual a percepção do espaço é ferramenta de fundamental importância para a acessibilidade, tanto no espaço aberto quanto no interior dos edifícios e residências. O "perceber", para pessoas cegas, é o resultado de muita sensibilidade e do treinamento de orientação e mobilidade ministrado pelas escolas especiais e apreendido no cotidiano. Muitas vezes, porém, a pessoa com a deficiência tem apenas as experiências limitadas à sua própria condição, criando assim um desenvolvimento social e de personalidade moldados ao padrão da cegueira.

A percepção que pessoas cegas têm da paisagem, mote deste estudo, é raramente considerada em pesquisas sobre a deficiência visual, que mais amiúde se propóem investigar as questóes da cognição, inclusão e acessibilidade e se inserem no âmbito de estudo da psicologia e da educação. Nesta pesquisa procurei em primeiro lugar ouvir pessoas com deficiência, o que fiz em diferentes situaçóes, a partir de 2005. Este período inclui os dois anos como aluna especial da área de Paisagem e Ambiente da FAU/ USP, (experiência detalhada em Método), já investigando especificamente a percepção da paisagem no âmbito da deficiência visual.

\section{A paisagem percebida pelos autores}

$\mathrm{Na}$ minha busca por autores que contemplassem a percepção da paisagem com o uso de outros sentidos, além da visão, encontrei referências em: Rasmussen (1986), Okamoto (1996), Lipai (1993), Bloomer (1977), Aprobato Filho (2008), Rykwert (2004), Hall (1981) Hillman 1993 Cullen (1961) Lynch (1980), Yázigi (2000), Yamaki (2001), Kish (2003) e Santos (1985). A obra de Pallasmaa (2008) que veio a preencher os meus questionamentos em relação ao tema da pesquisa. Nenhum desses autores, no entanto, relaciona o tema diretamente com a deficiência visual. Poucos deles fazem uma citaçáo mesmo que sutil sobre o assunto, em poucas linhas do texto, ponderando sobre algum fato isolado da cegueira.

Rasmussen (1986) registra que o objetivo de sua obra é explicar qual é o instrumento que a arquitetura toca, mostrar a amplitude que ela tem, e "despertar os sentidos para a sua música [...] perceber as coisas que nos cercam". Aponta que o arquiteto compóe a música que os outros tocarão (RASMUSSEN 1986, p.6). Mostra como as solas dos sapatos sentem a maciez e a rigidez das superfícies, apresentando calçadas de várias cidades (1986, p.16). Discorre sobre escalas e proporçóes, ressaltando o pensamento e as ideias pitagóricas (1986, p.96).

O autor descreve o ritmo na arquitetura (1986, p.119), Roma antiga, diversidade cultural. "Pessoas que vivem ao mesmo tempo em um país têm o mesmo senso de ritmo, movem-se de maneira seme- 
lhante, obtêm prazer com as mesmas experiências" (1986, p.127). Discorre sobre texturas e cita o escultor dinamarquês Thovaldsen, para quem “o barro é vida, o gesso é morte e o mármore é ressurreição”. Reflete sobre materiais e fachadas da arquitetura antiga, alvenaria de tijolos aparentes (1986, p.151). Contempla a luz do dia na arquitetura, apontando a sua importância no sentir a arquitetura. Compara a luz na arquitetura à luz das obras de arte, lembrando a pintura de Vermeer (1986, p.179).

De maior interesse à pesquisa, no entanto, o capítulo 10 (RASMUSSEN, 1986, p.219) versa sobre ouvir a arquitetura. "A arquitetura pode ser ouvida?" pergunta o autor. E pondera que, da mesma maneira como a arquitetura reflete a luz, reflete sons, paredes fazem o som reverberar. "Recebemos uma impressão total da coisa para a qual estamos olhando e não prestamos atenção aos vários sentidos que contribuíram para essa impressão.” Aponta que quando comentamos que uma sala é fria, nos referimos ao fato de não gostarmos das formas e materiais utilizados na sala, ou seja, decorre de "algo que sentimos". Ou se a acústica é alta, o som reverbera de forma desagradável, refere-se a "algo que ouvimos". Reflete que se meditarmos sobre isso poderemos nos lembrar de diferentes estruturas que conhecemos, e cita uma passagem abobadada da qual se recorda, que leva à antiga Copenhagen (1986, p.220). O arco reverbera os sons de maneira potencializada e o ruído faz parte das suas memórias de infância.

$\mathrm{O}$ autor menciona a reverberação do som dentro das igrejas e aponta que há cantos gregorianos que foram compostos especificamente para a antiga basílica de São Pedro. A reverberação torna o som mais opulento, diz Rasmussen (1986, p.225). O interior das igrejas possui voz própria, mostra o autor, registrando como diferentes materiais podem interferir na reverberação do som: "O teto era plano e relativamente baixo, de modo que atuava como uma caixa de ressonância, desviando os sons para os camarotes, onde eram absorvidos pelo madeiramento e estofamento" (RASMUSSEN, 1986, p.227). Chama a atenção para como diferentes materiais recebem e transmitem o som, como o mármore ressoava o som dos passos e como as salas de música das casas antigas eram preparadas com painéis de seda nas paredes para absorver o som.

Sobre a reverberação do som dos passos, e nas paredes e teto de edifícios, pessoas com deficiência visual estão constantemente alertas para esses sons, utilizando-se dessas mensagens para se organizarem espacialmente. A ponta da bengala faz o ruído característico do rastreamento, servindo de alerta para a presença da pessoa cega e ao mesmo tempo orientando-o pela reverberação. Assim, é mais fácil caminhar junto a um muro ou uma parede, quando se sente o eco que ela propicia, do que tentar se orientar em praça aberta. Essas experiências aparecem bem detalhadas nas oficinas e percursos acompanhados realizados no decorrer da pesquisa. Rasmussen aponta para a arquitetura que é percebida além do olhar. É citado por Pallasmaa (2008). 
Okamoto $^{18}$ aponta que na cultura ocidental é comum tratar as questóes ambientais com objetividade e racionalidade. $\mathrm{O}$ resultado desse excesso de racionalização é que sentimento, emoção, afetividade caem para segundo plano. Coloca que a relaçáo homem-espaço tem sido motivo de questionamento: como o homem percebe a realidade? Como interpreta o espaço arquitetônico? Reflete que as percepçóes decorrentes das sensações são mais do que reações a estímulos externos, já que sofrem interferência de estímulos internos (1996, p.10).

Em realidade e percepção do ambiente o autor reflete sobre os significados dos cenários e como neles a vida é vivida, o que lhes confere propriedades especiais. A realidade não é percebida apenas porque se está com olhos abertos, mas é, sim, percebida através de símbolos, mitos (1996, p.17). O autor cita conceitos de filosofia e pergunta se os sentidos oferecem a sensação sem a percepção, pois se ainda não há consciência, então como se adquire o conhecimento? Alguns filósofos pensavam que os conhecimentos só seriam possíveis se formados a partir de impressóes sensíveis. No século XVII, Locke afirmou que a mente das crianças recém-nascidas era uma página em branco e que os conhecimentos eram adquiridos pelos órgãos sensoriais. A apreensão do conhecimento viria das experiências vividas no meio ambiente (1996, p.22). Cita Tuan, quando diz que "percepção, atitude, valor e visão do mundo estão entre as palavras-chave para a nossa visão do meio ambiente físico, natural e humanizado” (OKAMOTO, 1996, p.24).

Podemos dizer que percebemos a realidade influenciados por nossas convicçóes e são elas que determinam os nossos pensamentos e sentimentos. E aqui lembramos o fogáo de lenha da casa da avó, nos depoimentos da protagonista Juliana, fogão onde o avô se sentava, pois tinha frio, fogáo que era o cenário das conversas na casa, de onde se espalhava a fragrância das cascas de laranja penduradas, o fogão que aquecia no inverno. $\mathrm{O}$ fogáo de uma loja, ou o fogáo em uma foto, pode ser uma peça neutra, mas as recordaçóes de Juliana, no entanto, conferem a ele qualidade e apreço.

Lipai $^{19}$ constata que a arquitetura só poder ser percebida, vivenciada, compartilhada a partir do momento em que a obra está concluída e pergunta se apenas neste momento realmente temos condição de perceber e avaliar o projeto. Não é possível desenvolver um método de conhecimento que permita que essa avaliação ocorra na concepção do projeto, no momento em que se concebe a arquitetura? Embora não seja este o mote de Os sentidos da paisagem, encontramos aqui alguns direcionamentos pertinentes à pesquisa, principalmente no capítulo $\mathrm{V}$, sobre a pesquisa dos espaços da mente (1993, p.143).

18 OKAMOTO, Jun. Percepção ambiental e comportamento. São Paulo : Plêiade, 1996

19 LIPAI, Alexandre Emilio. Arquitetura: percepçôes de uso do espaço e suas múltiplas realidades. Tese de Doutoramento FAU/USP 1993. 
Lipai cita Lynch: "A paisagem urbana entre seus múltiplos papeis tem também o de algo que deve ser visto, recordado, e causar prazer." Cita também Rapoport e os estudos relativos ao homem e o meio ambiente, que são os conceitos etológicos: residência, núcleo central, território, jurisdição, espaço e distância pessoais. Aponta que a etologia tem influenciado os estudos do meio ambiente com a conceituação de densidade, aglomeração (1993, p.145).

Indica também as diferenças físicas, visuais, cinestésicas, sonoras, olfativas, movimentação do ar, temperatura, táteis, sociais, temporais e as imagens mentais formadas pela cultura (1993, p.149). Relata experimentos feitos em bairros de São Paulo, como o da Bela Vista, para pesquisa de memória do observador e de sua capacidade de perceber o ambiente de maneira sensória (1993, p.213). Os elementos são detectados pela forma, como um muro de arrimo, ou pela arquitetura, como um edifício antigo, ou pelo colorido, como uma feira. Assim, passa-se a conhecer uma rua como a rua da feira, e não pelo seu nome oficial. Ou ainda a rua do muro, ou a rua da vila de casas (1993, p.219).

Considerou também referências sugeridas por Lynch, como vias ou caminhos, limites ou bordas, bairros, cruzamentos e elementos marcantes. Em vias e caminhos encontramos a referência de uma igreja na Avenida Rangel Pestana, de onde sempre se ouvia música. A avenida se caracteriza também como uma rua só de casas de couro. ${ }^{20}$ (1993, p.234). O autor cita Giulio Carlo Argan, ressaltando que "é preciso assegurar à cidade uma dimensão humana”, sendo para isso necessário observar, projetar, saber fazer, conhecer o ser humano em todos os seus aspectos, sociológico, antropológico, psicológico. $\mathrm{O}$ autor aponta que o arquiteto "deve abrir os seus canais sensoriais para desenvolvimento e aferição de estímulos observados da vivência da realidade em dois níveis: a sua própria e a dos 'outros indivíduos'.” (LIPAI, 1993, p.282).

Indica que para conhecer a realidade do sujeito e sua relação com o meio ambiente é preciso que se penetre nessa realidade, participe dela com o sujeito no próprio ambiente pesquisado. (1993, p.283). Notou que, se os sujeitos falam do local pesquisado, estando presentes nele, tendem a intelectualizar o discurso, abandonando as referências de memória. Considerou, portanto, mais eficaz ouvir as referências longe do local observado, pois assim os sujeitos recorriam ao seu arquivo-memória, ou a sua imagem mental buscando trazer "sensações, impressões e emoçôes" que produziam a imagem na mente (LIPAI, 1993, p.284).

Concluiu também que diversas áreas devem ser contempladas no estudo do ser humano, e que várias delas "possuem estudos e técnicas desenvolvidas com o intuito de conhecer [...] o universo do

20 Observo aqui que os protagonistas de Os sentidos da Paisagem reconhecem com facilidade as lojas que comercializam produtos de couro pelo seu odor característico. 
comportamento" (1993, p.286). O recurso de recorrer a várias áreas é comum em marketing, mas não em arquitetura, e aponta que há poucos estudos para detectar formas de conflitos provocados pela inadequação do ambiente e níveis de satisfação de uso (1993, p.287). Coloca a necessidade da humildade para se fazer e pensar a arquitetura. Aponta que é preciso ouvir, rever decisões, adequá-las ao usuário (1993, p.288).

O autor lista uma relação de perguntas feitas durante a pesquisa (1993, p.290 - A38): Quando você pensa no bairro onde mora, qual imagem vem a sua mente? Quais são os limites do seu bairro? Onde ele termina? Onde começa o bairro vizinho? Você gosta do bairro? Por quê? Como você usa o seu bairro? (cito apenas algumas). Tais perguntas expóem as preocupaçóes do autor e fazem subentender os caminhos percorridos para chegar à formulação dessas questóes.

Bloomer e Moore (1977) apresentam a sua obra como tendo sido composta para o ensino na escola de arquitetura de Yale University (1977, p.ix, tradução minha), Desde os anos 60, relatam, têm introduzido a arquitetura pelo ponto de vista de como edifícios são experimentados, antes de se preocuparem como são construídos. Acreditam que até conseguirem entender como edifícios afetam emocionalmente indivíduos e comunidades, como eles podem suprir pessoas com o sentido de alegria, identidade e lugar, não há maneira de distinguir arquitetura de qualquer outro ato cotidiano de construção. [..] "Vimos observando que o corpo humano, nossa mais fundamental possessão tridimensional, não tem sido a preocupação central no entender a forma da arquitetura; que a arquitetura, considerada como arte, é caracterizada nos seus estágios de projeto como arte visual abstrata e não como arte centrada no corpo.” (BLOOMER, 1977, p.x) Apontam que seus livros tencionam re-examinar o significado do corpo humano na arquitetura.

Sugerimos que só recentemente, com o surgimento das modernas academias, as crenças arquitetônicas tornaram-se severamente racionais e examinamos algumas controvérsias do pós-Cartesianismo filosófico e psicológico, embora eles pertençam a outros pontos de vista em arquitetura. [...] Aqui examinaremos modelos de percepçâo que influenciaram o século XX e nos aprofundaremos nas implicaçóes da teoria da imagem corporal e no reconhecimento e desenvolvimento do sentido háptico. Acreditamos que o mais essencial e memorável sentido de tridimensionalidade se origina na experiência corpórea e que esse sentido constitui a base para o entendimento do sentido espacial. [...] Uma das premissas herdadas do último século é a que mente e memória estão, de algum modo, desajustados com o corpo. Nós defendemos esta conexão corpo, mente e memória. 
Acreditamos que nossa relação espacial de altos e baixos, frente e fundo de fronteiras e margens compartilham espaços na nossa memória com assuntos conceituais e visuais. As experiências do nosso corpo, o que cheiramos e tocamos, o quanto estamos 'centrados', como os dançarinos dizem, não está trancado no presente imediato, mas sim pode ser relembrado através do tempo. (BLOOMER, 1977, p.x, tradução minha)

$\mathrm{O}$ autor indica que bem no início das nossas vidas medimos e entendemos o mundo a partir do nosso próprio corpo. $\mathrm{O}$ mundo se abre à nossa frente e se fecha atrás. As nossas referências cartesianas ditam regras precisas para a relação das coisas. Coordenadas cartesianas, projetos que saem das pranchetas com traços precisos, porém sem considerar o corpo como centro (esta constataçáo remete à obra de CUTSFORTH [1950], sobre como crianças cegas percebem o espaço em torno de seu berço).

Cita as casas de Bachelard, locais de fantasia (1977, p.2), discorre sobre os elementos da arquitetura, colunas, paredes, telhados, elementos compondo espaços (1977, p.7). Lembra que no início do século XIX o filósofo alemão Hegel enfatizou, mais do que seus predecessores, o aspecto mental da arte. Ele definiu a beleza como a imagem sensual de uma idéia. E reconhecendo que arte é também arte para os sentidos, Hegel referia-se apenas aos sentidos de percepção estética, visão e audição, excluindo o tato, o paladar e o olfato. Os sentidos da visão e da audição seriam sentidos ideais, por não consumir os objetos (1977, p.26). Cita o historiador Scott ${ }^{21}$ : "peso, pressão e resistência são parte habitual das nossas experiências corporais e nosso inconsciente instinto de mimetismo nos impele a nos identificarmos com o aparente peso, pressão e resistência das formas que vemos" (BLOOMER, 1977, p.27, tradução minha).

Refletindo sobre o porquê da visão ser considerada tão importante, explica que:

O sentido visual foi exaltado por tantos séculos, que outras maneiras de sentir os objetos tiveram que ser consideradas definitivamente inferiores e menos importantes na formulação de conhecimento dos objetos, incluindo os edifícios. Na própria palavra Iluminismo ecoa a metáfora da visão de Platão, que conecta visão, luz e verdade. No final do século XIX, quase todos os problemas estéticos que tratavam as formas tridimensionais eram tratados automaticamente como problemas visuais. Em contraste com a aparente superioridade da visão, o sentido do tato foi reduzido a um tipo de atividade Vitoriana feita com a ponta dos dedos, melhor ainda se feita com luvas, mais comparável a medir com paquímetro, ao invés 
de medir com o corpo todo. Mesmo os escultores dessa época tratavam as esculturas como sendo artes visuais derivadas de desenhos. (BLOOMER, 1977, p.29, tradução minha).

Segundo o autor, a noção de que há cinco sentidos foi aceita durante o Iluminismo apesar de surgir no século XIX uma considerável confusão na tentativa de se identificar e categorizar os sentidos.

Muitas sensaçóes podiam ser percebidas e entre 1830 e 1930 e tentou-se fazer um inventário dessas sensaçóes. $\mathrm{O}$ tato, o quinto sentido determinado por Aristóteles, não obteve cuidadoso exame, registra o autor. Não havia órgãos como os olhos, ouvidos, nariz e boca, e a pele não se configurava como órgão dos sentidos. Consequentemente o sentido do tato foi subdividido em cinco sensaçōes: Pressão, aquecimento, frio, dor, cinestesia (sensibilidade ao movimento). Esse confuso inventário de sensaçôes derivadas do toque, com suas variadas referências a dor de estômago, dor irritante etc. etc. dificilmente agregava elegância aos estudos da estética. Em 1930 essas tentativas de categorização dos sentidos pareceram excessivamente complexas e foram abandonadas. (BLOOMER, 1977, p.33, tradução minha).

Gibson (1966) relacionou cinco sentidos, mas, diferentemente de Aristóteles, definiu-os como sistemas perceptivos, capazes de obter informaçóes sobre o percebido sem a interferência de processos intelectuais. Ao contrário de visão, audição, olfato, paladar e tato, Gibson relaciona: sistema visual, sistema auditivo, sistema paladar/olfato, sistema básico de orientação, e sistema háptico. Para a arquitetura, o autor coloca como os mais importantes: sistema básico de orientação, e sistema háptico, pois facilitam o entendimento da tridimensionalidade.

Relata que J. J. Gibson contribuiu enormemente organizando a confusão com o tato e adicionando outro sentido básico para a nossa consideração. Sua estratégia era considerar os sentidos como agressivos, solicitadores de mecanismos e não passivos, como meros receptores de sensaçóes. Assim, ele pode compor um inventário compacto dos sentidos focando nas informaçóes que o meio fornece ao corpo, mais do que na variedade de aparatos sensórios e na resposta do corpo.

O modelo de percepçáo de Gibson é objetivo e possui um método claro de abordagem, reflete o autor. Ao reagrupar os sentidos pelo tipo de informação que os indivíduos buscam nos seus deslocamentos pelo meio ambiente, ele nos presenteou com um rico modelo mecânico de percepção, do qual podemos entender alguns processos que geram experiências em arquitetura. Além do mais, por ter colo- 
cado todo o corpo, e não apenas os olhos e os ouvidos no centro da experiência perceptiva, ele ajudou a desfazer a confusão contida nas especulaçôes da estética européia.

As indicações do autor aplicam-se à pesquisa Os sentidos da paisagem, na investigação de como pessoas cegas se percebem, como percebem o seu corpo. Cegas, por não enxergarem a distância, muitas dessas pessoas andam pelas ruas imaginando que também não são percebidas. Pergunto então: como se dá a percepção do seu próprio corpo? Como pessoas cegas se imaginam? Têm consciência dos seus membros, mesmo quando não os usam? Qual é a influência deste perceber e não-perceber na maneira como se colocam no mundo? Conversar com mães de crianças cegas congênitas sobre estes e outros assuntos pode ajudar, mas muitas vezes é evitado por elas próprias, por trazer lembranças dolorosas de aceitação da realidade.

Bloomer faz considerações sobre a percepção em ambientes fechados e abertos, objetos ao alcance das mãos, experiências corporais (1977, p.43). Cabe aqui citar a experiência com o passeio da protagonista Leninha no Parque Cemucam, quando, ao entrar em galpão aberto, ela notou diferença no som da nossa fala, notou o eco e a reverberação nas paredes.

$\mathrm{Na}$ abordagem da casa, na maneira como pessoas sentem o espaço de maneira diferente (1977, p.46-47) é interessante lembrar como Juliana, cega congênita, ainda menina, corria pela casa para atender ao telefone, com total domínio e entendimento do espaço. O autor considera desenhos de cidades, projetos de residências e sítios históricos, arquitetos famosos. Na bibliografia indicada, encontro autores já que contribuem na pesquisa Os sentidos da Paisagem: Bachelard, Edward Hall, J. J. Gibson, Calvino, Rasmussen, Tuan, Rykwert, entre outros.

Na obra de Aprobato Filho (2008), o prefácio do livro, assinado pelo historiador Elias Thomé Saliba, convida o leitor a viajar pela paisagem sonora urbana, mostrando a transformação de São Paulo e lembrando a gravidade de termos perdido a capacidade de dar atenção à audiçáo, relevando-a a um papel auxiliar, o que ocasionou uma espécie de "surdez crônica". Cita Derrick de Kerckhove, sucessor de McLuhan, que propôs um exercício simples de fecharmos os olhos e imaginarmos o mundo à nossa volta. Como ele indica, iríamos nos surpreender com a quantidade de sons. Sugere que depois deveríamos abrir os olhos e tentar manter a percepção dos mesmos sons. Aponta que a tarefa é difícil, já que nossas funçôes sensoriais são seletivas e nos habituamos a entregar aos nossos olhos a parte mais importante da nossa força mental (2008, p.14).

Saliba reflete que também monges tibetanos e poetas (e cita Verlaine e Claudel) recomendavam fechar os olhos como técnica de meditação ou exercício de estímulo sinestésico (relação subjetiva que se estabelece espontaneamente entre uma percepção e outra que pertença ao domínio de um sentido diferente). São maneiras de arrostar a tirania do olhar. Aponta como o autor apresenta a influência e os efeitos dos sons no cotidiano da capital paulista, os sons antigos do trote de animais das carroças, os sons 
de carros de bois e os toques dos sinos que foram silenciados pelas ferragens dos trens, pelas campainhas dos bondes, pelas buzinas de automóveis, pelos apitos das fábricas.

"Quem vê sem ouvir fica muito mais inquieto do que quem ouve sem ver" (citando Walter Benjamin). Registrar sonoridades urbanas é tarefa fundamental para salvar lembranças. Aprobato cita James Lovelock, em As Eras de Gaia:

[...] com o aumento da população aumentou também a proporção obrigada a levar uma vida urbana, sem contato com a natureza. Nos últimos dois séculos quase todos nos tornamos habitantes da cidade [...] Eu me pergunto se este não será o resultado da privação sensorial. Como é que podemos venerar o mundo vivo se não conseguimos mais escutar o canto dos passarinhos em meio ao ruído dos automóveis ou sentir a suavidade do ar fresco? Como podemos nos admirar com Deus e o Universo se jamais vemos as estrelas por causa das luzes da cidade? Se você acha exagero, pense na última vez que ficou deitado no gramado sob a luz do sol, sentiu o cheiro do mato e ficou espiando o vôo das cotovias e ouvindo o seu canto. (APROBATO FILHO, 2008, PG. 23)

Cita também Merleau-Ponty que, em Fenomenologia da Percepção, apresenta reflexóes intimamente ligadas às preocupaçóes de seu trabalho, como a sinestesia e a unidade dos sentidos, refletindo sobre "a visão dos sons ou a audição das cores”. Cita também do mesmo autor as relações interpretativas estabelecidas entre o corpo humano e o mundo percebido: "meu corpo é a textura comum de todos os objetos [...] e o instrumento geral da minha compreensão" (APROBATO FILHO, 2008, PG. 32). Aponta Gadamer (1997), sobre o homem moderno viver a era da imagem e coloca que: "ele cria, veicula e consome imagens em ritmos a cada dia mais atrozes e estonteantes. Aquilo que vê o atinge de maneira muito mais profunda do que aquilo que saboreia, sente, escuta e cheira” (APROBATO FILHO, 2008, p.34).

Teria a nossa capacidade de ouvir sido alterada pelo ruído excessivo das cidades modernas? Parafraseando novamente Schafer, em O ouvido pensante, aponta que "Ao contrário de outros órgãos dos sentidos, os ouvidos são expostos e vulneráveis. Os olhos podem ser fechados, os ouvidos não, estão sempre abertos. Os olhos podem focalizar e apontar a nossa vontade, enquanto os ouvidos captam todos os sons do horizonte acústico, em todas as direções”(APROBATO FILHO, 2008, p.35). A obra tem muito a esclarecer sobre o som como elemento intrínseco ao cotidiano das cidades. 
Rykwert $^{22}$, historiador, professor na Universidade da Pensilvânia, indaga o que é necessário para criarmos cidades com melhores condiçóes de vida, uma cidade que agrade mais aos seus habitantes. O autor analisa e pondera a respeito de várias cidades principais de vários países, entre elas São Paulo, Brasília, Cidade do México, Berlim, Nova Deli, Nova York. Cidades planejadas, cidades que cresceram fora de controle, assim como cidades menores. Discute estilos e ornamentação em arquitetura, sucessos e fracassos de traçados urbanos, sugerindo como resgatar a qualidade das cidades, o sentido do lugar.

Refletindo sobre o fato de as cidades terem uma mistura de coisas boas e ruins, pergunta se temos as cidades que merecemos. Comenta também que lendo o que escrevem urbanistas, economistas, sociólogos, fica surpreso de como o tecido físico da cidade é pouco considerado, o toque, o cheiro e as revelaçóes da cidade (RYKWERT, 2004, p.6). E se propóe a considerar a cidade "como ela se apresenta aos nossos sentidos e tentar uma leitura do que a sua aparência pode revelar ou esconder". O autor comenta que os cidadãos constantemente estão experimentando as cidades, apreciando, tocando, cheirando, adentrando, consciente ou inconscientemente o tecido urbano (2004, p.7).

Rykwert considera que pontos de referência são essenciais, pois sem eles o cidadão não consegue entender a cidade (2004, p.186). E cita Linch, que fez um estudo pioneiro de como se chega a essas leituras. $\mathrm{O}$ autor aponta, no estudo de Linch, as características do meio urbano, ou seja, fronteiras, bairros, caminhos marcados pela cidade. Aponta ainda que "qualquer cidade, bairro ou quarteirão precisa não apenas de pontos de referência que os indiquem, como também de locais mais ou menos diferenciados para reunióes semipúblicas ou semiprivadas - além de locais de encontros como tavernas, restaurantes, cafés e bares [...]".

Segundo o autor, as cidades do século XX têm reduzido esses pontos. Bares e restaurantes não possuem mais características próprias que os diferenciem, pois transformaram em "franquias quase idênticas de refeiçôes rápidas, vendendo chips ou batatas fritas, [...] hambúrguer, frango frito, pizzas, os onipresentes refrigerantes [...]. A natureza homogeneizada das franquias de refeiçóes rápidas resulta em instalaçóes que não guardam relação alguma com sua localização e que não podem servir como pontos de referência marcantes [...]”. (RYKWERT, 2004, p.187). Nas entrevistas desenvolvidas nesta pesquisa são comuns os depoimentos de pessoas que identificam locais da cidade pelo seu cheiro, aberturas e fechamentos, escadarias, sons, características específicas de locais escolhidos para encontros, ou apenas usados como referências de orientação.

O psicólogo Hillman (1993) preocupa-se em levar a reflexão psicológica para além dos consultórios. Aborda cidades, atividades urbanas, cidadãos, colocando que não apenas a psicoterapia, mas a 
arquitetura, o planejamento urbano, o design e todas as ciências humanas são atingidas pela percepção da alma do mundo, da cidade como realidade psíquica. Propóe o retorno da alma no mundo e inclui a urbanidade como campo válido de experiências, nos sensibilizando para a beleza do nosso entorno.

No capítulo 3, que tem o título do livro, o autor explica que a alma adoece com a tensão urbana e aponta cinco ideias "que mostram como e onde a alma existe na cidade" (HILLMAN, 1993, p.37-42).

1. Reflexão: um olhar para o outro, diminuição da vaidade e do narcisismo, deixar de lado a superficialidade para ser capaz de uma reflexão mais profunda. Faz uma analogia com a reflexão do espelho, que se presta ao deslumbramento.

2. Profundidade. Pensar a profundidade da cidade em termos de níveis: níveis de iluminação, qualidade de texturas, buscar significados mais profundos enfatizando a interioridade de onde estamos ou do que está à nossa frente.

3. Experiências emocionais e a memória. Temos lembranças afetivas de parques, de ruas, de lojas. "a cidade é uma história que se conta para nós à medida que caminhamos por ela".

4. A imagem dos símbolos - placas, sinais, grafite que se comunicam diretamente com os olhos e cabeça. "O sentido corporal de orientação está perdido", pondera o autor.

5. Noção de relaçóes humanas, que se dão principalmente no nível do olhar. Esta é parte fundamental da vida da cidade, aponta o autor: "como nos olhamos uns aos outros, como olhamos a face uns dos outros, assim é que se dá o contato com a alma”.

O autor cita os lugares onde é possível se encontrar, se olhar, locais para pausar, para encontros, tais como bebedouros, cafés. E os lugares para se tocar "onde os corpos possam se ver uns aos outros" propondo uma intimidade "crucial para a alma”. "Se a cidade não tem lugares para pausas, como é possível o encontro?" Hillman coloca que quando pensamos em alma e ligaçóes de alma, pensamos em intimidade, e que isso não tem a ver com o tamanho da cidade. Como indica ele, uma cidade é construída sobre relaçôes humanas "gente se encontrando". Uma cidade tem lugares construídos para haver quebra do aparente propósito da cidade: os cafés, cervejarias, lanchonetes, vestiários, banco da praça ao sol, onde é possível fazer pausas.

Trata do caminhar pela cidade, refletindo que pessoas de carro não enxergam a face das pessoas, “a perda da face é o resultado do aumento dos automóveis” observa, citando o psicólogo holandês Bernd Jager. Olhar uma cidade é perceber o bazar, o mercado, as alamedas. E define a origem da palavra grega polis, que originalmente significava multidão. "Uma cidade é o vaivém de uma multidão de pessoas comuns nas ruas. Então o fato de não encontrar rostos por não andar entre a multidão abstém-nos de nosso próprio rosto; também nos abstém da própria cidade como foi originalmente imaginada [...]" (HILLMAN, 1993, p.52). 
$\mathrm{O}$ autor reflete que uma cidade é construída de relações humanas e que caminhar pelas ruas deixando de lado a tirania do automóvel pode ser um interessante exercício. Caminhando é possível perceber, pelos sons dos passos, se o dono do calçado é homem ou mulher; o andar leve ou pesado passa informaçóes sobre o peso da pessoa, seu ritmo, sua pressa.

Reflito sobre a interessante descrição de Helen Keller, de como percebe os passos de dois garçons em um restaurante de hote ${ }^{23}$. Passos podem vir sozinhos, acompanhado da bengala ou em companhia de outros passos e podem sugerir o roçar de corpos, o farfalhar do tecido. A paisagem mantém um constante diálogo com os nossos sentidos. Vozes deixam transparecer o estado de espírito. Os sons são importantes para a comunicação e facilitam a localização para pessoas que não enxergam, embora possam causar desorientação, quando em excesso.

Para o autor, caminhar pode uma "terapia meditativa" que acalma e, nesse sentido, cita Heidegger que recomendava o caminhar na floresta para filosofar; lembra a escola de Aristóteles, peripatética, que pregava o discurso durante a caminhada.. Cita também Nietzsche que dizia que só têm valor as ideias que temos quando caminhamos, "ideias laufenden - ideias correntes, não ideias sentadas". "Caminhando estamos no mundo, encontramo-nos num lugar específico e, ao caminhar nesse espaço, tornamo-lo um lugar". E pergunta: "uma cidade que não permite caminhar, é também uma cidade que nega a moradia para a mente?"

Hillman discorre longamente sobre a caminhada pela cidade, mostrando que desde Egito antigo a caminhada era retratada em hieróglifos. Relata que se caminhava muito pelos jardins da Europa do século XVIII e que os jardineiros eram os grandes urbanistas da época, "paisagens inteiras eram erigidas ou niveladas, canais desviados, vistas panorâmicas descobertas, labirintos construídos”.

23 Descobri que os passos variam na hapticidade de acordo com a idade, o sexo, e as maneiras do caminhante. É impossível confundir os passinhos de uma criança com o modo de andar de uma pessoa crescida. O passo do jovem, forte e livre, difere do modo sedado dos de meia-idade e do passo do homem velho, cujos pés se arrastam pelo chão, ou chocam-se com ritmo lento e vacilante. Descalça, uma menina anda rápido, com ritmo elástico, que é bastante distinto do passo mais grave da mulher idosa. Eu ri do rangido dos sapatos novos e do tropel de uma empregada doméstica corpulenta dançando na cozinha. Um dia, no saláo de jantar de um hotel, uma dissonância tátil chamou minha atenção. Sentei-me imóvel e ouvi com os meus pés. Descobri que dois garçons estavam andando para lá e para cá, mas não com a mesma marcha. A banda estava tocando, e eu podia sentir a vibração das notas musicais no chão. Um dos garçons andou no andamento da música, de maneira graciosa e leve, enquanto o outro ignorou a música e correu de mesa em mesa, na batida de alguma dissonância da sua própria mente. Seus passos me fizeram lembrar um vigoroso tropel de cavalos. Keller, Helen. The world I live in. Dover, 2009. Originalmente publicado por The Century Company, New York, em 1908. Tradução minha. 
Há uma história da propriedade e do desenvolvimento da terra que deveria ser parte da consciência de todo urbanista. $\mathrm{Na}$ arte da jardinagem, era essencial que olhos e pés ficassem satisfeitos: os olhos para ver, os pés para atravessar; os olhos para abarcar e conhecer o todo; os pés para permanecer nele e vivenciá-lo. (HILLMAN, 1993, p.54)

O autor lembra o professor Robert Dupree ${ }^{24}$, refletindo que o olho e o pé não deveriam percorrer o mesmo caminho. Cita também o poeta William Shenstone quando diz que quando um local já foi visto o pé não deve se dirigir a ele pelo mesmo caminho percorrido pelos olhos. Ao contrário, devemos perder um objeto de vista e só depois nos aproximarmos dele de maneira indireta; o poeta defende que o pior traço é aquele da avenida reta aonde o pé tem que caminhar por onde o olhar já passou. Para ele, “caminhar é uma maneira de descobrir novas paisagens" [...]. Sem isso, "o pé fica escravo do olho, caminhar torna-se chato, uma mera questão de cobrir distâncias” (HILLMAN, 1993, p.55).

Hillman aponta que o século XVIII cuidou das necessidades da alma, construindo pelos caminhos o que chamavam de a-há: "uma pequena mureta, cercas-vivas escondidas, valetas que, ao surgirem inesperadamente, provocavam um a-ha, interrompendo a caminhada, forçando o pé a desviar e a mente a refletir." E compara o caminhar da época ao dos dias atuais, feito com pressa, quando caminhar se faz apenas com o olhar. Não queremos labirintos, nem surpresas, ou enfrentar mato, buracos, lixo. "[...] cidades modernas têm problemas nas calçadas uma vez que os pés são ignorados”, registra o autor. As ruas oferecem risco e violência, trancamos portas e janelas. Segundo o autor, os urbanistas desenham um mundo por onde não se caminha, com arranha- céus, shopping centers e ruas que são meros acessos a eles. $\mathrm{Na}$ visão do autor, as cidades são ruas, local de comércio, aglomerado de pessoas, possibilidades de encontros, e a vitalidade da cidade dependem do caminhar (HILLMAN, 1993, p.46).

Hillman cita um conto de Norton Juster, sobre um menino chamado Milo que chega a uma cidade onde todos andam apressados, olhando só para o chão, indo diretamente para os seus destinos, usando atalhos. E por ninguém prestar atenção à cidade, ela vai gradativamente ficando mais feia e suja, e as pessoas passando por ela cada vez mais depressa. Até que a cidade vai desaparecendo, as ruas e construções vão sumindo. Hillman usa o conto para ilustrar a situação de hoje, quando nas cidades grandes as construçóes estáo perdendo sua realidade estética, sensorial, prédios que não servem mais nem aos olhos nem aos pés, que são simplesmente escritórios, depósitos, amplos espaços vazios. Prédios que não foram 
feitos para se caminhar. $\mathrm{O}$ autor questiona se pode um psicólogo recomendar calçadas mais interessantes, que levem os pés a uma exploração, "recantos, fontes, desníveis, diferentes perspectivas?” A cidade como um lugar da alma (HILLMAN, 1993, p.57).

Esta é uma obra interessante que une psicologia e urbanismo, levantando as questôes da apreensão da paisagem urbana com o uso dos sentidos, a sensibilidade para se perceber os espaços na sua totalidade e essência, o ato de caminhar e se deslocar pela cidade colocando-se por inteiro nesse ato. Reflito que, se viver nas grandes cidades já é um desafio para pessoas que enxergam, não enxergar na metrópole é um agravante desse desafio. Quais sáo os lugares de pausa para pessoas cegas? Nas ruas de uma cidade como Sáo Paulo há pouco ou quase nenhum lugar para se sentar. Para as entrevistas nos encontramos em lanchonetes, muitas vezes do SESC SP, ou em outros restaurantes, pizzarias, lanchonetes. Isso porque não há áreas de estar na cidade, ela parece ter sido desenhada apenas com vias de acesso, de percursos.

Um fator determinante para os encontros é a condução, o transporte público. Os locais escolhidos devem ser próximos ao Metrô, a um ponto de ônibus conhecido. Muitas das pessoas cegas marcam encontro na entrada do Metrô. Comunicam-se por telefone celular, quem chega primeiro avisa, se possível andam em companhia. Nenhum pudor, falam alto, fazem algazarra, muitos risos, clima divertido. Não vendo os olhares de estranhamento, parecem se sentir sozinhos. Passeios no parque fazem sucesso, caminhar por ruas cheias de gente é desconfortável, lugares abertos com muito barulho fazem perder o senso de direção.

Se poucos cidadáos videntes caminham pela cidade, se preferem o automóvel, pouco convivem com cegos, pois estes usam transporte público e na sua grande maioria caminham pela cidade. E por caminharem, queixam-se da pressa e da falta de educação de muitas das pessoas que, na aglomeração do centro da cidade, tropeçam em suas bengalas, amassam-nas, sem ao menos parar para pedir desculpas. Para o Hillman, caminhar é uma terapia meditativa. Naturalmente, para quem enxerga, pois pessoas cegas caminham atentas à situação física do percurso, às outras pessoas que vêm de outras direçóes, aos perigos de atropelamentos, carros saindo de garagens, obstáculos no caminho, buracos etc.

O conto de Norton Juster, citado por Hillman, nos remete à percepção e à memória das pessoas cegas que caminham pela cidade. Sendo uma caminhada de atenção, de alerta, e não um flanar, algumas dessas pessoas apresentam enorme facilidade para apreender e memorizar o espaço. É o caso de Hélio ${ }^{25}$, 
por exemplo, e a descrição que ele faz do caminho para se chegar até a sua casa, que fica em um bairro antigo de São Paulo: "Entra na Lins de Vasconcelos, vira na França Pinto terceira à esquerda, sobe até a Domingos de Moraes, vira a direita na Domingos, tem uma placa Lins à esquerda, cruza e desce a Lins, segunda ou terceira à direita tem o Habibs, desce, desce, desce, lá embaixo tem o Delboni, cruza para pegar a Ricardo Jafet do lado esquerdo.... faz uma curva etc.”. Talvez videntes possam desenvolver, como algumas pessoas cegas, a habilidade para perceber os detalhes do caminho. Seria uma maneira de caminhar com alma, como propóe o autor.

$\mathrm{O}$ arquiteto americano Paul Goldberger esteve em São Paulo em novembro de 2011 para o evento Arq.Futuro, onde lançou o seu livro mais recente $A$ relevância da arquitetura. Em entrevista para a revista Veja ${ }^{26}$ a sua reflexão: "Numa cidade, a rua é mais importante que os prédios. A rua é uma idéia antiga que funciona perfeitamente. Não precisamos reinventá-la. Uma das razóes pelas quais Nova York funciona tão bem é que a cidade se construiu voltada para a rua. É na rua que está a vida das cidades." Sobre o efeito prejudicial dos shopping centers construídos nas cidades, observa: "São como um aspirador, tirando as pessoas das ruas".

Santos ${ }^{27}$ parte do pressuposto que aprofundar o conhecimento sobre as formas de apropriação dos espaços de uso coletivo corresponde a entender melhor os processos de desenvolvimento da cidade. Há dois tipos de espaços, aponta ele: o construído, fechado, e o aberto, de uso coletivo. A pesquisa tem como objeto principal o bairro do Catumbi. Lá coexistem residências antigas, fábricas, oficinas, serviços públicos e particulares. (SANTOS, 1985, p.14) Trata-se de um bairro que luta por manter os seus valores.

Em Metodologia de Pesquisa, o autor coloca como foram os levantamentos, efetivados através de trabalho de campo. Usou-se a técnica de observação participante, relata, a mais adequada para se obter informação sobre o objeto empírico. Obteve-se assim dados e documentos etnográficos como entrevistas, fotos e gravaçóes, material este que completa a formação teórica (1985, p.15).

Uma rua é mais do que uma via de passagem, "uma rua é um universo de múltiplos eventos e relações” (SANTOS, 1985, p.24). E, citando Briggs (1972), "a expressão 'alma da rua' significa um conjunto de veículos, transeuntes, encontros, trabalhos, jogos, festas e devoçôes”. Ruas tem caráter e podem ser agitadas, tranquilas, [...] são locais onde a vida social acontece. $\mathrm{O}$ autor nota que no número 25 da Rua Valença havia um misto de armazém, quitanda e bar, reconhecido como importante apoio

26 Revista Veja, Editora Abril, Edição 2244 - Ano 44 - No 47 - 23 de novembro de 2011, p.116

27 SANTOS, Carlos Nelson F. (coord) Quando a rua vira casa. Sao Paulo : Ibam/finep, 1985. 
pela população. Ponto de encontro para conversa de mulheres, telefonemas de urgência, compras rápidas, o armazém evoca espaços domésticos.

O autor aponta outro armazém, o São José, que, com diferentes balcões, divide funções de bar e armazém. O balcão dos homens fica mais próximo da rua e vende bebidas e cigarro; o dos fundos, em contrapartida do bar, é um espaço feminino, remete ao mundo da casa, vende produtos de armazém. "Uma dona de casa pode entrar e sair sem chamar a atenção dos homens que estáo no bar" [...] "O espaço do armazém é produto das relaçôes do seu arranjo 'material' com seus usuários e apresenta uma vitalidade que varia de acordo com seu padráo rítmico". Descreve os frequentadores pelo horário da frequência (SANTOS, 1985, p.44-5).

A memória da rua está registrada na fachada contínua do correr de casas, nos beirais, nos trabalhos de cantaria, nas portas e janelas "que se sucedem numa curiosa simetria" [...] Os elementos arquitetônicos são, conscientemente, dotados de significado no discurso dos moradores. [...] A análise de espaços deve levar em conta as atividades que se dão nos seus diversos recortes. Assim como a rua é a forma de utilizá-la, o espaço é o uso que permite" (SANTOS, 1985, p.47).

Encontramos exemplos nas indicaçóes de Cullen ${ }^{28}$ que propóe recursos frequentemente usados na arquitetura, como texturas, fechamentos e aberturas, pisos, noçóes como intimidade, cordialidade, aqui e ali, continuidade, perfumes, sons. Espaços trabalhados assim podem tocar diretamente a percepção de pessoas cegas conferindo afetividade e propiciando condições favoráveis à orientação. É possível fazer uma analogia das indicaçóes do autor com relatos de pessoas com deficiência visual que caminham pela cidade. Para elas é mais fácil caminhar por um via estreita (1978, p.45) onde o som da bengala provoca eco, do que em grande espaço aberto, como o das praças, onde se perde os parâmetros para a orientação. A alternância de tipos diferentes de pisos (1978, p.53) desperta interesse e é outro fator se orientação. No entanto, é preciso cuidado nas escolhas, pois texturas com depressóes profundas prendem a ponta da bengala.

Pontos de encontro (1978, p.26) são excelentes comunicadores para a deficiência visual: "eu o espero aqui". Praças com espelhos d'água, cascatas, arbustos que se agitam ao vento, além de intensificar o prazer da permanência, apontam referenciais para a mobilidade. Mobiliário urbano, objetos com significado, esculturas, monumentos, além de atrair olhares constituem-se pontos de referência, dialogam com pessoas cegas, que também sentem diferença de ritmo, escala, topografia (1978, p.73). Árvores criam ambientes agradáveis, modificam a umidade do ar, farfalham ao vento, as folhas secas 
fazem ruído característico quando pisadas, as flores deixam o ar com odor diferente (1978, p.82-83). Muros e cercas soam de maneira diversa quando presentes na caminhada, apresentando grande diferença de som e de passagem de ar (1978, p. 88-89).

Acrescento a estes espaços categorias adicionais como: fechado, aberto, silencioso, com ruído, desafiador, ambiente com tratamento de acessibilidade, de marcha fácil ou acidentada, espaços de convivência e afetividade, espaços de fácil orientação, funcionais, de visita rápida ou longa, receptivos e inóspitos, que proporcionam conforto, segurança, flexibilidade. Lembrando Aristóteles, os percursos podem também investigar a percepção que pessoas cegas têm dos conceitos: acima, abaixo, atrás, à frente, à direita, à esquerda.

Para compreender melhor o sujeito da minha pesquisa busquei me aprofundar em outras epistemologias, conhecimento que contribuiu para delinear um perfil mais acurado da pessoa cega e do complexo mundo da deficiência visual. No estudo da deficiência, preconceito e estigma, Amaral (19921994-1995), Crochik (2006), Sekkel (2008), Goffman (1963). Na memória e história oral, Bosi (19792003). Bosi tem grande importância para a pesquisa por tratar de temas sempre presentes nos depoimentos dos protagonistas.

Nos estudos da percepção, Gibson (1966), Montagu (1986), Merleau-Ponty (1994), Classen (1996), Griffin(1959), Ackerman (1992) e Schiffman (2005). Diderot (2000), Condillac (1993) Bachelard (1993) contribuem na conceituação filosófica, com alguma citação sobre deficiência visual. Vem de Bachelard o tratamento poético ao espaço interno das casas, teoria que se assoma em uníssono com as memórias das pessoas cegas que frequentemente citam memórias de infância, férias em casa de parentes, cômodos preferidos de se estar, momentos de encanto.

Encontramos referências em textos que, embora não tenham teor científico, contribuem de maneira importante para a compreensão das questóes abordadas na pesquisa. Na poesia de Pessoa (1967), e Woolf (1993); na literatura, nas coloridas descriçôes do cotidiano de Proust (1983) e no conto do inglês H. G. Wells The Country of the Blind, publicado pela primeira vez em 1904 no Strand Magazine, e republicado em 1939 pela Golden Cockerel Press com o título The Country of the Blind and Other Stories. Até mesmo Brillat- Savarin ${ }^{29}$, em 1848, fez uma breve análise dos sentidos, ao escrever sobre gastronomia. (BRILLAT-SAVARIN, 1989, p. 31-37). Contribuem diretamente no tema da deficiência visual, Saramago (1995), Sacks (1989- 1995), Borges (1974). Inúmeros outros autores tratam da paisagem em seus aspectos de partilha sociocultural. As obras de todos são tratadas detalhadamente ao longo do trabalho. 


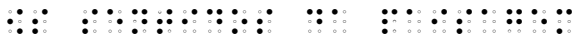

Busquei completar o conhecimento adquirido com a leitura de obras autobiográficas de pessoas que perderam a visão e neste campo, sim, encontrei vasta bibliografia: Eames (1997), Hull (1990 e 1997), Kish (2003), Kleege (1999), Kuusisto (1999) Lusseyran (1983) Queiróz (1986), Espínola Veiga (1946), Sá (2004), Keller (2009), Grunwald (1999), White (1999), entre outros. Estes títulos trouxeram muito do que eu já vivenciava no contato com as pessoas cegas no projeto Ponto a Ponto, e que descrevo em $O$ envolvimento com o tema. 



\section{Pessoas Cegas não enXergam COM OS OLHOS}

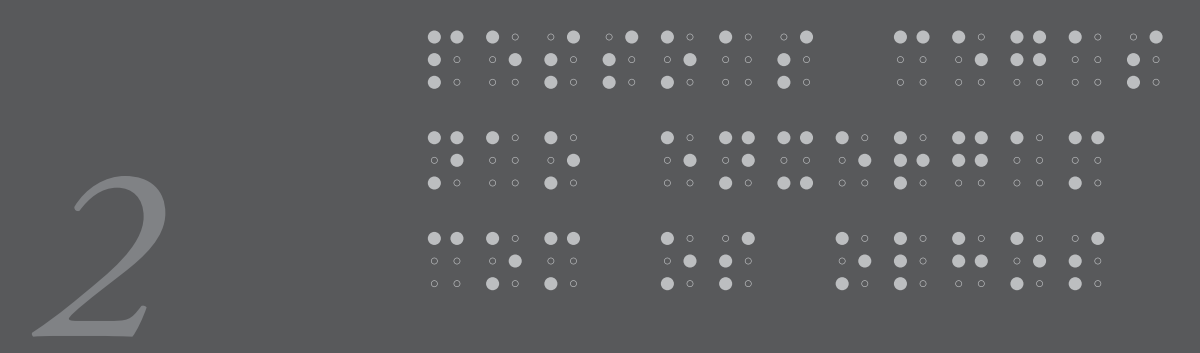

O tato é mais que o ver É mais que o ouvir É mais que o cheirar

Manoel de Barros ${ }^{1}$

Pessoas cegas náo enxergam com os olhos. Enxergam com as mãos, a boca, com os ouvidos, nariz, pés, enxergam com todo o corpo. Recebem estímulos quando estão parados ou em movimento, percebem com a ajuda do vento, da umidade e temperatura, sentem os deslocamentos de ar. Conhecem os locais pela sua textura, guiam-se pelos sons, distinguem ruídos. Enxergam pela cinestesia, pelo sentido háptico, percebem de maneira intuitiva, com sensibilidade e experiência. Entendem as razóes do interlocutor pela entonação da sua voz e hesitações, pelos seus silêncios, identificam pessoas pelo seu perfume, seus passos, pelo seu ritmo, seu jeito de chegar. Exercitam constantemente a memória e por isso destacam-se pela capacidade de acumular dados e referências. Calculam as distâncias percorridas 
com a ajuda da memória cinética. Utilizam-se de todo esse conhecimento na sua vida profissional, pessoal e social, desempenhando com eficácia e criatividade inúmeros papeis, compensando assim a falta da visão ${ }^{2}$.

O filósofo Milligan (1995), cego desde dois anos de idade, em carta escrita ao filósofo vidente Magee coloca que não consegue entender o porquê de pessoas videntes considerarem a perda da visão como um cataclismo (MAGEE; MILLIGAN, 1995, p. 44, tradução minha). A perda da visão não pode e não deveria ser experimentada como qualquer coisa além de uma perda séria. Milligan ficou cego em decorrência de câncer de retina e a despeito da perda da visão, aos dezesseis anos já cursava a Universidade de Edinburgh onde se graduou aos dezenove anos; foi bolsista do Balliol College em Oxford, onde se formou, Cum Laude, em filosofia, política e economia. No entanto, passou vários anos exercendo atividades pouco desafiadoras como a de estenógrafo, por não conseguir trabalho na sua área profissional.

O filósofo relata a sua dificuldade para conseguir trabalho, apesar da sua formação privilegiada. Em um determinado momento, desesperado por uma colocação, candidatou-se para a função de datilógrafo em um jornal de Glasgow. Segundo ele, esta era uma vaga que naquela época os jornais tinham dificuldade para preencher e para a qual ele estava bem qualificado, pela rapidez e exatidão tanto em datilografia quanto estenografia. Apesar disso, nunca foi chamado para uma entrevista. Mais tarde, acidentalmente, conheceu um funcionário do jornal e teve conhecimento de que ainda estavam com dificuldade para preencher a vaga e que suas qualificaçóes tinham impressionado favoravelmente. Apenas não foi chamado para a entrevista porque havia escadas no prédio.

Milligan aponta a falta de conhecimento das pessoas em relaçáo à deficiência visual, refletindo que há inúmeros prédios com escadas de todo tipo e que são frequentados por pessoas que não enxergam. Para elas, as escadas não são mais perigosas do que para as pessoas que enxergam. Videntes que usam os olhos para enxergar os degraus, diz ele, não conseguem entender como uma pessoa cega faz uso de uma escada. Realmente, a noção da cegueira tem enorme efeito para a nossa cultura ocidental, refém da hegemonia da visão. É devastadora para uma cultura voltada para o visual, que privilegia formas, cores, brilhos, em detrimento dos sons e odores e cujos meios de comunicaçáo atrelam a notícia mais à imagem do que ao texto anunciado.

2 Faz parte do folclore da deficiência visual acreditar que pessoas cegas, diversamente das videntes, têm mais desenvolvidos os sentidos da audição, tato, olfato e paladar. Este trabalho defende que os sentidos de qualquer pessoa podem ser desenvolvidos e que a atenção transforma uma sensação em percepção. Sobre imputar tributos às pessoas cegas, ver também citaçáo de GOFFMAN (1988), no Capítulo 3. 
Ricardo, bibliotecário aposentado, músico, cego desde jovem, também reflete sobre a maneira como a sociedade percebe a deficiência visual:

Porque cada ser humano é único, ele tem umas experiências de vida, outro tem outras e como ele lida com essas experiências é uma forma particular de cada um e a própria cegueira é diferenciada. A deficiência visual é muito forte; as outras deficiências são fortes, surdez, tetraplegia, as pessoas sentem piedade ou preconceito, mas as pessoas têm medo da deficiência visual, pois têm muito medo de perder a visão. Preferem perder uma perna, amputar a mão, mas a visão é uma coisa muito séria, de perder o contato com o ambiente, em termos do visual. Têm medo porque a perda da visáo implica numa porçâo de coisas que ela não consegue fazer, entâo ela tem essa impressão muito forte, "se eu fosse cego eu me matava" eu já ouvi várias vezes. Quando acontece alguma pane elétrica e fica tudo escuro, videntes não sabem o que fazer, ficam completamente sem ação, o autocontrole foge. Por isso o interesse em fazer alguma coisa pelo deficiente visual fica esquecido, fica afastado, exatamente em função das pessoas não quererem nem falar do problema. Dai a razão de poucos trabalhos em deficiência visual. É mais fácil ideias para que o deficiente visual se molde à realidade do que a sociedade ou a realidade mudar para recebê-las, é mais cômodo, questão de comodismo mesmo.

A cegueira não propicia fáceis condiçóes, em um mundo concebido predominantemente por conceitos relacionados à visão. Mas, ao contrário do que muitos pensam, a vida não acaba com a perda da visão. Pessoas que ficam cegas na vida adulta passam por uma reorganização motora e sensorial e aprendem a aperfeiçoar o seu estado de atenção, a se tornarem perceptivas ao que acontece ao seu redor. Conforme a visão se apaga, outras modalidades de percepção passam a fazer parte da vida dessa pessoa, que se utiliza então de outros instrumentos para a apreensão do seu entorno ${ }^{3}$.

3 "Os incríveis paratletas". O documentário apresenta a preparação dos ginastas paraolímpicos do Reino Unido para os jogos de 2012. Para entender como o cérebro do atleta funciona durante um jogo de futebol para cegos, o Dr. Rhodri Cusack, do Conselho Médico de Pesquisa da Universidade de Cambridge, submete o atleta Dave, jogador de futebol, cego, a uma tomografia computadorizada. O exame é feito enquanto o atleta é exposto a um determinado ruído (a bola de futebol usada por pessoas cegas tem um guiso). A tomografia mostra inicialmente que o cérebro de Dave responde aos sons exatamente como aconteceria com alguém que enxerga. Apenas algumas partes usadas na audição se ativam. Mas então algo surpreendente acontece: a parte do cérebro que lida com a visão também começa a responder aos sons. Dr. Cusack explica que os cientistas frequentemente supóem que as regiões sensórias têm conexôes fixas, mas o que vemos no exame é o que os cientistas chamam de plasticidade: as regióes visuais do cérebro começam a processar os sons na falta de informaçôes visuais. http://sportv.globo.com/site/programas/sportv-reporter/noticia/2011/10/deficiente-visual-desafia-jogadores-que-enxergam-para-partida-de-futebol.html. Exibido em outubro/2011 pelo SportTV Reporter - Globosat. 
Ronaldo ${ }^{4}$, engenheiro de 59 anos, cego, relata que começou a apresentar perda da visão aos sete anos de idade. Na escola, sentia dificuldade para distinguir as palavras no quadro-negro, situação logo detectada pela professora. No entanto, na época nada foi constatado pelo oftalmologista consultado e o garoto saiu do exame com um diagnóstico de "preguiça visual". Com onze anos, a dificuldade para enxergar já era bastante severa. E novamente os exames médicos nada constataram. Aos dezessete anos, o jovem tinha apenas um resíduo de visão.

À noite, com a pouca iluminação dos salóes de baile, relata, entrava em fila, sempre atrás de algum amigo, guiando-se pela nesga branca do colarinho da camisa social. Para convidar alguma menina para dançar, era terrível, diz ele, convidava só as meninas de vestido branco. A escolha da parceira se fazia prestando atenção na conversa do grupo, arriscando, desenvolvendo artimanhas a partir das informaçóes dos amigos, que não se davam conta de que Ronaldo não conseguia enxergar na pouca luminosidade do local. Época de muita vergonha e muitas limitaçóes, diz ele.

Com severa retinopatia ainda não constatada em exame oftalmológico, o jovem se valia da visão periférica para se locomover. Caminhava pelas ruas como se estivesse olhando as vitrines das lojas, mas na verdade mirava o caminho que percorria. Nas conversas, no entanto, o recurso incomodava o interlocutor que não entendia a razão de não ser encarado de frente. As limitaçôes, a retração e a inibição do jovem chegavam a ser confundida com doença mental pelas pessoas que conviviam com a família, já que durante as visitas o rapaz desaparecia. Ronaldo relata que náo gostava de conviver com essas pessoas, pois era difícil até enxergar a mão do outro no momento do cumprimento. Era impossível reconhecer o rosto dos amigos que passavam do outro lado da rua e, como a deficiência náo era declarada, o relacionamento ficava comprometido.

Ronaldo descreve as saídas noturnas do grupo para caçar rãs. Como não enxergava à noite e não conseguia caçar, encarregava-se da fieira dos animais capturados. E seguia o grupo pelo calor dos corpos e pelo som dos passos, pulando com dificuldade as pedras do riacho: onde o amigo batia o pé, tinha que se apressar para também apoiar o seu pé, no mesmo lugar de onde tinha vindo o som. Desenvolvia suas próprias técnicas, embora nem sempre acertasse. A retinopatia foi finalmente detectada aos dezessete anos, com mais de oitenta por cento de perda da visão.

O recurso usado por Ronaldo, ao combinar os sentidos na sua orientação, é chamado de sinestesia. É de Merleau-Ponty a reflexão sobre o fato de os sentidos se comunicarem entre si:

4 Protagonista desta pesquisa, em depoimento de 21/05/2011 
A percepção sinestésica é a regra e, se não percebemos isso, é porque o saber científico desloca a experiência e porque desaprendemos a ver, a ouvir e, em geral, a sentir, para deduzir de nossa organizaçáo corporal e do mundo tal como o concebe o físico, aquilo que devemos ver, ouvir e sentir. E, citando Schapp 5 : Os sentidos comunicam-se entre si e abrem-se à estrutura da coisa. [...] A forma dos objetos não é o seu contorno geométrico: ela tem uma certa relação com a sua natureza própria e fala a todos os nossos sentidos, ao mesmo tempo que fala à visão. A forma de uma prega em um tecido de linho ou de algodão nos faz ver a flexibilidade ou a secura da fibra, a frieza ou o calor do tecido. [...] No movimento de um galho que o pássaro acaba de abandonar lemos a sua flexibilidade ou a sua elasticidade, e é assim que um galho de macieira e um galho de bétula imediatamente se distinguem. (MERLEAU-PONTY, 1994, p. 308)

Sobre os sentidos se comunicarem entre si, temos a contribuição do psicólogo Gibson, que investigou a psicologia ambiental e considerou os sentidos como agressivos, solicitadores de mecanismos e não apenas passivos recebedores e detectores de sensaçóes. Os sentidos, considerados por Gibson como sistemas perceptivos seriam sistemas ativos, constantemente em busca de informaçóes e apresentados por ele como sistema visual, sistema auditivo, sistema olfato-paladar, sistema básico de orientação e sistema háptico. Estes dois últimos, o sistema básico de orientação e o sistema háptico têm grande significado, segundo o arquiteto americano Bloomer (1977, p. 33), pois contribuem sobremaneira para o entendimento da tridimensionalidade, essencial para a experiência da arquitetura.

Sáo individuais as características de cada pessoa com deficiência visual, assim como a própria deficiência, que assume feiçóes específicas e varia de pessoa para pessoa. A maneira como aceitam a deficiência e administram as características da nova realidade após a perda da visão; as facilidades e dificuldades de locomoção, de percepção do entorno, a percepção das relaçôes sociais que não incluem a pessoa cega, a convivência sem o sentido da visão, tudo tem características únicas, exclusivas de cada pessoa. Dessa maneira, é impossível se referir a alguém que têm deficiência visual imputando-lhe qualificações genéricas, rotulando-a pelas características supostamente atribuídas pela deficiência visual.

5 SCHAPP. Beiträge zur Phänomenologie der Wahrnehmung, Inaugural Dissertation. Göttingen, Kaestner, 1910, e Erlangen, 1925 . 


\section{A deficiência visual}

A dimensão social da cegueira pode ser considerada a partir dos dados que revelam a quantidade de pessoas afetadas. Segundo a Organização Mundial da Saúde - OMS, existiam em 1990, no mundo, aproximadamente 38 milhóes de cegos e 110 milhóes de pessoas com deficiência visual grave ${ }^{6}$, dos quais 72 milhóes com baixa visão ou visão subnormal. Em 1996 esses dados ampliaram-se para 135 milhões de pessoas com baixa visão e 45 milhões de cegos, estando $90 \%$ deles em países em desenvolvimento. A previsão é que até o ano 2020 esse número duplique.

\section{No mundo, a cada 5 minutos um adulto fica cego. Uma criança fica cega a cada minuto. ${ }^{7}$}

De acordo com os dados do Censo de 2010 do Instituto Brasileiro de Geografia e Estatística IBGE, 23,9\% da população brasileira possui algum tipo de deficiência. Desses 45.623.910 cidadãos com deficiência, 35.791.488 pessoas, ou seja, 18,8\% da população brasileira, têm algum tipo de deficiência visual. O censo de 2010, em relação ao de 2000, simplificou a maneira de apurar os dados e passou a investigar pessoas com dificuldade permanente de enxergar e dependência de lentes, de acordo com a classificação:

Náo consegue de modo algum - pessoa permanentemente incapaz de enxergar

Grande dificuldade - pessoa com grande dificuldade permanente de enxergar, mesmo com auxílio lentes Alguma dificuldade - pessoa com alguma dificuldade permanente de enxergar, mesmo com auxílio lentes

6 Diversamente do que podemos supor, o adjetivo cego aplica-se a pessoas com diversos graus de visão residual. Segundo a Dra Maria Aparecida Haddad, médica do Serviço de Visão Subnormal do Hospital das Clínicas da Faculdade de Medicina da USP, as causas de cegueira e baixa visão nas crianças podem ser congênitas, degenerativas, pré-natais, ou ainda causadas por distrofias. $\mathrm{Na}$ vida adulta, a mais comum é o glaucoma, cuja característica é a perda da visão periférica e, depois dos 60 anos, a degeneração da mácula, ou as retinopatias causadas pela diabetes - estatísticas prevêem que o número de idosos em 2010, no Brasil, deverá perfazer $10 \%$ da população. Segundo o Portal da Retina, em 1966 a OMS registrou 66 diferentes definiçóes de cegueira. Há pessoas que só conseguem contar dedos a curta distância, as que só percebem vultos, ou as mais próximas da cegueira total que só percebem sinais luminosos. A cegueira total, chamada de Amaurose, pressupóe a perda completa da visão. www.portaldaretina.org.br

7 VISÃO 2020: O Direito à Visão. Organização Mundial da Saúde (OMS) 
$\because \because \quad \because \because \because: \because \because \because \because \quad \because \because \quad \because \because \because \because \because \because \because \because$

Nenhuma dificuldade - pessoa sem qualquer dificuldade permanente de enxergar, ainda que com uso de lentes

O quadro abaixo apresenta os dados preliminares da amostra ${ }^{8}$.

Censo Demográfico 2010 - Resultados Preliminares da Amostra

\begin{tabular}{|l|r|r|}
\hline & Total & $\%$ pop. bras. \\
\hline Têm alguma deficiência & 45623910 & 23,9 \\
\hline Brasil & Total & $\%$ pop. bras. \\
\hline Deficiência Visual & 6.585 .308 & 3,5 \\
\hline Cegos & 528.624 & 0,3 \\
\hline Baixa Visão & 6.056 .684 & 3,2 \\
\hline
\end{tabular}

\begin{tabular}{|l|r|r|}
\hline São Paulo & Total & $\%$ pop. bras. \\
\hline Deficiência Visual & 1.209 .666 & 2,9 \\
\hline Cegos & 151.842 & 0,4 \\
\hline Baixa Visão & 1.057 .824 & 2,6 \\
\hline
\end{tabular}

\begin{tabular}{|l|r|r|}
\hline Deficientes Visuais por Região & Total & \% pop. bras. \\
\hline Norte & 574.823 & 3,6 \\
\hline Nordeste & 2.192 .455 & 4,1 \\
\hline Sudeste & 2.508 .587 & 3,1 \\
\hline Sul & 866.086 & 3,2 \\
\hline Centro - Oeste & 443.357 & 3,2 \\
\hline
\end{tabular}

Deficientes Visuais por Região

Total $\quad \%$ pop. bras.

\begin{tabular}{|l|r|r|}
\hline Visual & 6.585 .308 & 3,5 \\
\hline Motora & 4.442 .246 & 2,3 \\
\hline Intelectual & 2.617 .025 & 1,4 \\
\hline Auditiva & 2.147 .366 & 1,1 \\
\hline
\end{tabular}

Incluindo "alguma dificuldade"

Deficientes Visuais por Região

Total $\quad \%$ pop. bras.

\begin{tabular}{|l|r|r|}
\hline Visual & 35791488 & 18,8 \\
\hline Motora & 13.273 .969 & 7,0 \\
\hline Intelectual & 2.617 .025 & 1,4 \\
\hline Auditiva & 9.722 .163 & 5,1 \\
\hline
\end{tabular}


Segundo o mesmo censo, no Brasil há 528.624 mil pessoas cegas, 151.842 delas vivendo em São Paulo, capital, cidade de difícil trânsito para pessoas sem limitaçôes físicas e fortemente restritiva para pessoas com deficiência. O jornal Folha de São Paulo' ${ }^{9}$, em matéria de 2004, comenta que a cidade está de tal maneira despreparada para receber essas pessoas que aproximadamente $70 \%$ delas permanecem em casa a maior parte do tempo, fugindo das ameaças da cidade. São pessoas que pouco partilham os espaços de cultura e lazer, as universidades e áreas de vegetação urbanas.

Para o cidadão sem limitaçóes físicas, caminhar pelas ruas de uma cidade como São Paulo é uma diligência que exige paciência e vigor. Se, no entanto, a pessoa tiver alguma deficiência, especialmente deficiência visual, sair de casa pode significar enfrentar barreiras muitas vezes intransponíveis. Nos seus percursos, no seu cotidiano, pessoas cegas têm que aprender a sobrepujar a falta do sentido que governa a apreensão a distância. E, na medida em que a cidade não torna disponíveis as condiçóes necessárias para o acesso a todo e qualquer espaço de maneira independente, ela os obriga a uma condição de subordinação às pessoas que enxergam, e a confiar na leitura e no entendimento que a pessoa vidente faz do lugar.

O número de pessoas afetadas pela deficiência visual cresce consideravelmente. Bebês prematuros, que graças ao desenvolvimento da medicina sobrevivem com peso abaixo de 1 quilo, podem desenvolver retinopatia da prematuridade. Segundo a oftalmologista Rosane C. Ferreira, vice-presidente da Sociedade Brasileira de Oftalmologia Pediátrica, 80\% dos bebês prematuros que nascem com peso entre 700-1000gramas devem desenvolver retinopatia e 10\% podem ficar cegos sem tratamento. Segundo a médica, cerca de 850 crianças prematuras com ROP ficam cegas por ano, no Brasil. ${ }^{10}$ Outrossim, conforme a população envelhece, cresce o número de pessoas com problemas de visão. Considerada uma das perdas mais importantes das pessoas idosas, a degeneração da mácula é responsável por mais de cinquenta por cento dos registros na American Foundation for the Blind, uma das principais associaçóes americanas ligadas à deficiência visual.

O fundador e presidente do grupo de suporte da associação norte-americana Association for Macular Diseases, Nick Stevenson, é veterano da Segunda Guerra. Sofreu com os problemas de degeneração da mácula por dezessete anos e, apesar da deficiência, viaja por todo o país organizando simpósios, ensinando como lidar com a doença e principalmente com os transtornos emocionais. Ele diz que náo estamos preparados para essa deficiência, que chega de maneira inesperada. Quando um dos cônjuges adquire a

9 Projetos abrem caminhos para deficientes. Aureliano Biancarelli. Folha de São Paulo. Cotidiano. 18/01/2004

10 Fonte: http://www.sbop.com.br/sbop/site/conteudo/SITESBOP3-prematuridade.pdf -

http://www.universovisual.com.br/publisher/preview.php?edicao=1203\&id_mat=293 - acesso em 20/12/2011 
deficiência, há uma enorme sobrecarga para o outro. Temos obrigaçôes uns para com os outros, diz ele. Preferimos imaginar que o mundo tem uma obrigação em relação a nós, que temos a doença. Queremos que o mundo nos diga: "entendemos que você tem um problema, podemos alterar as nossas rotinas. Você é valioso, vamos atendê-lo, mudar nosso cotidiano por você” (GRUNWALD, 1999, p. 80, tradução minha). Mas nada disso acontece e o mundo continua em seu ritmo cada vez mais rápido.

A questão da deficiência visual faz parte do nosso presente e tem sido tratada ao longo da história pela bíblia, nas fábulas e parábolas, na mitologia e em histórias que são do conhecimento universal. Incluiu personagens famosos, pintores, músicos, escritores, que, em algum momento de suas vidas, tiveram que lidar com as dificuldades ocasionadas pela perda total ou diminuição severa da visão. Obras literárias e cinematográficas expóem o assunto; o documentário de 2001 Janelas da Alma ${ }^{11}$ relata experiências de 50 entrevistados, anônimos e famosos, e as relaçóes com a deficiência, mostrando como a cegueira é, antes de tudo, uma questão social e cultural. Pessoas cegas sempre tiveram participação ativa na sociedade, desempenhando funçóes, desenvolvendo carreiras profissionais, conquistando um espaço que lhes pertence, embora a sociedade insista em vê-los com benevolência e até como dependentes e incapazes.

\section{A percepção do entorno}

A cegueira congênita difere em muito da cegueira adquirida. Pessoas adultas podem contar com referências de quando ainda enxergavam, embora, posteriormente, sem o auxílio da visão, essas referências possam se manifestar alteradas. Por sua vez, crianças cegas congênitas em seus primeiros anos de vida , quando ainda não se locomovem sozinhas, ficam impossibilitadas de construir e organizar referências. É necessário que elas sejam estimuladas a se movimentar para introjetar conceitos de espaço, escala, dimensão e aos poucos adquirirem independência na mobilidade.

Em estudo sobre orientação e mobilidade, Lora ${ }^{12}$ pondera como a falta da visão não impossibilita a pessoa de conhecer o seu entorno. E aponta como ferramentas para a percepção do mundo a audição, o sistema háptico (tato ativo), a cinestesia, a memória muscular, o sentido vestibular e, finalmente, o olfato. $\mathrm{Na}$ audição, indica que o ouvido é o principal órgão de percepção e profun-

11 O documentário de Walter Carvalho e João Jardim entrevistou 19 pessoas com deficiência visual, entre elas o Prêmio Nobel de Literatura José Saramago, o neurologista Oliver Sacks e o poeta Manoel de Barros. Premiado como Melhor Documentário Brasileiro na 25a Mostra BR de Cinema. Filme de 2001, com 73 minutos de duração.

12 LORA, Tomásia Dirce Peres. Descobrindo o real papel das outras percepçóes, além da visão, para a orientação e mobilidade. P58. In: MACHADO. Edileine Vieira [et al.]. Orientação e mobilidade: Conhecimentos básicos para a inclusão do deficiente visual. Brasília: MEC, SEESP, 2003 
didade do ambiente. Cita Lowenfeld, que recomenda estimular a atenção das crianças para os sons, para usá-los como "pistas de orientação". Ruídos de portas e janelas abrindo ou fechando "favorecem a relação do ambiente interno com o externo da casa e suas relaçóes de espaço e distância" (LORA, 2003, p. 58).

A educadora indica também que as fontes sonoras que estão à direita, alcançam primeiro o ouvido direito, fazendo intervalo de fraçáo de segundo antes de ser reconhecido pelo ouvido esquerdo. Deste modo, sons que vêm de todas as direçóes, a ponto de virarmos a cabeça para melhor percebê-los, se tiverem duração suficiente, podem ser bons indicadores de localização e distância, contribuindo para se caminhar com segurança.

Quando a criança tem dificuldade para se orientar em casa, o rádio ligado serve como fonte sonora constante que permite localizar as dependências da casa e mantê-la orientada através da relação que estabelece com a fonte sonora, assim como os ruídos característicos existentes nos respectivos ambientes: cozinha, banheiro, lavanderia, quintal e outros. A pessoa cega mantém a sua linha de direção e por vezes atravessa as ruas de mão única localizando o som paralelo dos carros, identificando quando o som do trânsito está à sua frente, o que indica um cruzamento de ruas. (LORA, 2003, p. 60)

Também na rua, passos de outras pessoas podem servir de indicadores de por onde se deve caminhar. Explica o conceito de "sombra sonora"13, e como pessoas cegas podem usá-la para perceber "troncos de árvores, postes, caixas de correio, carros e caminhóes estacionados no meio fio, as colunas dos pátios escolares, as quinas dos prédios e outros obstáculos, possíveis de serem detectados quando esta habilidade é desenvolvida".

Masi ${ }^{14}$ reflete como crianças cegas têm dificuldade para sair de si mesmas e compreender o espaço em torno de si. Portanto, é importante que sejam ensinados a ela os conceitos espaciais que "possibilitam a construção de representaçôes espaciais, topológicas, projetivas e euclidianas” (MASI, 2003, p. 42).

Anterior - frente, em frente de, em face de, de frente, para frente, diante, à frente.

Posterior - atrás, por trás, posterior, para trás, depois.

Superior - em cima, acima, sobre, par acima, alto, ascendente.

13 "A sombra sonora é uma área de relativo silêncio atrás de um objeto que filtra suas ondas, como se fosse uma sombra produzida por algum objeto, quando o raio de luz de uma lanterna incide sobre ele".

14 MASI, Ivete De. Conceitos : aquisição básica para a orientação e mobilidade. In: : MACHADO. Edileine Vieira [et al.]. Orientação e mobilidade: Conhecimentos básicos para a inclusão do deficiente visual. Brasília: MEC, SEESP, 2003 
Inferior - de baixo, abaixo, sob, para baixo, baixo, descendente, debaixo de, por baixo de.

Lateral - direito, esquerdo, lateralmente a, ao longo de, ao lado de.

Proximidade - próximo, próximo a, ao lado de, afastado de, distante, longe, rente, perto de, aqui, lá, em oposição a.

Interno - para dentro de, dentro, no interior de, dentro de, interno, para o interior.

Externo - fora, externamente, fora de, externo, exterior.

Outros - sentido horário, anti-horário, oposto, através de, paralelo, perpendicular, ao redor de, na direção de, de cabeça para baixo, meio, entre, no meio, centro, sobre, distante, anterior, posterior, superior, inferior, interior, adjacente, medial, mediano, pontos cardeais: norte, sul, leste, oeste; colaterais: nordeste, noroeste, sudeste, sudoeste.

O sistema háptico, também conhecido como tato ativo, segundo Lora, é a percepção sensorial que mais facilita o conhecimento do mundo para a pessoa cega. Se com as mãos podemos, intencionalmente, tocar algo, com o tato passivo é possível sentir de forma não intencional, como a sensação da roupa por sobre a pele, o braço repousado na cadeira, a parede na qual se encosta, as informaçóes transmitidas pela ponta da bengala, pela textura do piso, pela posição do sol.

Segundo a educadora, a cinestesia é a sensibilidade para perceber movimentos musculares ou das articulaçóes e uma de suas funçóes é a memória muscular, que possibilita o uso de escadas com tranquilidade. Essa habilidade estimulada nas pessoas cegas é inata em nós, mas, videntes, preferimos usar a visão para apreender as dimensões dos degraus. Características físicas de percurso também podem ser memorizadas e usadas como referências para a locomoção. O sentido vestibular é responsável pelo equilíbrio (sentido labiríntico) e pelas mudanças de direcionamento nos percursos.

Em relação ao olfato, Lora fornece indicações para orientação e identificação de ambientes e cita como exemplo cozinhas, sanitários, consultórios dentários, jardins e parques, açougues, farmácias, postos de gasolina, entre outros. Indica também que as pessoas com deficiência visual devem ser estimuladas ao uso do sentido do olfato, pois este é eficiente auxiliar no desenvolvimento da mobilidade e localizaçáo de sítios urbanos, assim como cuidados com a própria saúde, tornando-se independente na escolha e utilização de medicamentos, produtos de higiene pessoal etc. A criança cega, constata o estudo, deve ser exposta a diferentes caminhos, paisagens diferentes das habituais, de maneira que possa apreender o mundo por meio dessas interaçóes, explorando ao máximo os estímulos olfativos (LORA, 2003, p. 63). 
Cutsforth $^{15}$, em obra histórica publicada em 1930, descreve a percepção do mundo pelas crianças que não enxergam. Segundo o autor, ele próprio cego, a criança que enxerga, logo nos primeiros anos se apercebe do que está ao seu redor, ampliando constantemente o seu mundo de estimulaçáo. Por outro lado, a percepção da criança cega fica restrita ao que está ao alcance das suas mãos, dependendo, portanto, do que lhe é apresentado por meio de palavras ou do tato. Deste modo, ela passa a usar de maneira diferente o seu equipamento sensorial, e a perceber o que acontece a sua volta de maneira diversa de como percebem os que enxergam:

A forma mais objetiva de experiência humana é a visual. Ela dá detalhes que nenhum outro sentido pode fornecer; ao mesmo tempo traz objetos em relaçóes simultâneas de posição, distância, tamanho e forma. Apesar da criança normal que enxerga perceber inicialmente relações espaciais em grau muito imperfeito, ela começa, cedo, a construir um mundo espacial visual e, a objetividade assim adquirida empresta forma e lugar ao que é ouvido e tocado. Uma criança imobilizada, à qual falta a objetividade que a visão dá, é completamente incapaz de organizar padróes sonoros de extensão , direção ou localização espacial. Nas crianças cegas congênitas as experiências sonoras não têm estas qualidades, até que ela seja capaz de estabelecê-las através de atividade motora, isto é, até começar a engatinhar e a andar. (CUTSFORTH, 1969, p. 15)

Assim, ao contrário da criança que enxerga, a criança cega cresce sem parâmetros de extensão, direção e organização espacial. Do espaço limitado em que vive, fica difícil distinguir, sem o apoio da visão, vozes, pessoas, e a direção de onde elas vêm. No entanto, ao longo de sua vida, muitas das pessoas cegas desenvolvem recursos que possibilitam a apreensão do espaço: aprendem a caminhar pela cidade, em casa e no trabalho, orientando-se de maneira satisfatória no seu cotidiano. Helen Keller, surdacega em consequência de doença adquirida aos dois anos de idade, descreve a sua própria paisagem:

As infinitas maravilhas do universo são reveladas à medida que somos capazes de recebê-las. A agudeza da nossa visão depende não de quanto podemos ver, mas de quanto conseguimos sentir. [...] A natureza entoa suas cançóes mais primorosas para aqueles que a amam. [...] Estou proibida de usar adjetivos como frescor, clarão, escuro e melancólico? Eu tenho

15 CUTSFORTH, Thomas D. The blind in school and society. Edição publicada pela primeira vez em 1933 e destruída em 1943, restando apenas algumas cópias; reeditado pela American Foundation for the Blind (AFB) em 1951. O cego na escola e na sociedade. Tradução e edição patrocinada pela Campanha Nacional de Educação dos Cegos - Ministério da Cultura, 1969. 
andado nos campos pelas primeiras horas da manhã. Senti a roseira carregada de orvalho e fragrância. Senti as curvas e os encantos do meu gatinho quando ele brinca. [...] Combine o infinito espaço do ar, o calor do sol, a prevalência dos vacilantes odores, as nuvens que são descritas para o meu espírito compreensível, o frequente romper do solo de um riacho ou a vastidão de um lago agitado pelo vento, a tátil ondulação de uma montanha de que me lembro quando estou distante dela [...] O limite mais distante que meu pensamento alcança com clareza é o horizonte da minha mente. A partir desse horizonte, eu imagino aquele que os olhos marcam”. (KELLER, 2009, p. 41-43, tradução minha)

Diderot (2000), em sua Carta sobre os cegos, questiona:

Como é que um cego de nascença forma ideias das figuras? Creio que os movimentos do seu corpo, a existência sucessiva de sua mão em vários lugares, a sensação não interrompida de um corpo que passa entre seus dedos, fornecem a noção de direção. Se ele os desliza ao longo de um fio bem esticado, adquire a ideia de um linha reta; se segue a curva de um fio frouxo, adquire a de uma linha curva. Mais geralmente, ele tem, por experiências reiteradas do tato, a memória de sensações experimentadas em diferentes pontos: depende dele combinar essas sensaçóes ou pontos e formar com elas figuras. Uma linha reta, para um cego que não é geômetra, não é mais que a memória de uma série de sensaçôes do tato, situadas na direção de um fio tenso.[...] Nós combinamos pontos coloridos; ele, de seu lado, combina apenas pontos palpáveis ou, para falar mais exatamente, apenas sensaçóes do tato de que tem memória. (DIDEROT, 2000, p. 105)

Sobre as linhas retas, Helen Keller contribui:

O que uma linha reta significa para você? Significa várias coisas. Simboliza dever. Parece ter a qualidade de inexorabilidade que o dever tem. Quando tenho alguma coisa a fazer, que não pode ser deixada de lado, eu sinto como se estivesse caminhando adiante, numa linha reta, compelida a chegar a algum lugar, ou seguindo para sempre, sem desviar para a esquerda ou para a direita. É isso o que significa. Para escapar dessa moralidade deve-se perguntar: como se sente a linha reta? Sente-se, como suponho que ela se parece, reta, alongada, inerte, sem fim. A eloquência ao toque não reside 
nas linhas retas, mas nas linhas tortas, ou em muitas curvas e retas juntas. Aparecem e desaparecem, ora profundas, ora superficiais, quebradas, esticadas ou aumentadas. Elas se elevam ou se afundam sob meus dedos, eles estáo cheios de súbitos inícios e pausas, e sua variedade é inesgotável e maravilhosa. (KELLER, 2009, p. 3, tradução minha)

Cutsforth reflete sobre a estimulação tátil (CUTSFORTH, 1969, p. 17), considerando a preferência que crianças cegas têm por objetos com forma de fácil entendimento. Relata um fato ocorrido com Laura Bridman que, quando criança, tinha como seu brinquedo favorito as longas botas de couro do pai. Brincava com elas por horas seguidas, seguindo suas formas e contornos, percebendo-as como o seu brinquedo mais facilmente compreensível: agradável ao toque, maleável, cheias de reentrâncias e saliências.

Ackerman reflete sobre a importância do toque e cita pesquisa realizada na Filadélfia com pessoas que teriam sobrevivido a ataques cardíacos. Nas investigaçóes, distinguiam-se pessoas solteiras ou casadas que possuíam animais de estimação. Estas sobreviviam por mais tempo. $\mathrm{O}$ ato de acariciar animais é calmante e produz efeito curativo. Cita trecho da pesquisa: "Criamos nossos filhos em uma sociedade não-táctil e temos que compensar essa carência com criaturas não-humanas. Primeiro com ursinhos de pelúcia e cobertas, depois com animais de estimação. Quando não existe o toque, surge nosso verdadeiro isolamento" (ACKERMAN, 1992, p. 154). Synnott ${ }^{16}$ compara hábitos culturais (To touch or not to touch?) em relação a abraçar, beijar, embalar bebês, citando noçóes de higiene e conhecimento passado por pediatras e famílias ao longo dos séculos.

À exploração tátil das crianças segue a percepção auditiva. Cutsforth indica que a audição é um caminho objetivo para a criança com cegueira congênita, que logo começa a reconhecer vozes e aprender melodias. Assim, aos poucos, a criança desenvolve a percepção do seu entorno, identificando e nomeando os sons da casa como o telefone, o relógio, o piano. Torna-se consciente de si mesma e da deficiência ainda muito jovem e poderá fazer referências ao fato de não enxergar com apenas três anos. O psicólogo indica que com essa idade a condição da cegueira é aceita como qualquer outra característica corporal, e que só mais tarde poderão existir conflitos emocionais. A criança cresce aprendendo a se comportar, a combinar cores de roupas, a vestir-se de maneira harmoniosa para ser aceita socialmente. É nesse momento que ela passa a adquirir independência para se mover dentro de casa, e para facilitar a sua orientação deve ser estimulada a entender a configuraçáo espacial da casa. (CUTSFORTH, 1969, p. 18)

Nesse sentido, a sua tarefa será facilitada se houver pontos sonoros de indicação de localizaçáo, como um relógio de tique-taque sonoro, ou um sino que balance ao vento. No entanto, a criança cega 
pode conhecer o som da campainha, o toque do telefone, a buzina de um carro, sem saber como é o aparelho de telefone, o automóvel, a porta de entrada da casa e, sobretudo, sem saber distinguir um do outro. Daí a importância de se apresentar o mundo à criança, o entorno de onde ela vive, os objetos, os conceitos, e incluí-la nas relaçôes sociais, mesmo nas que não a envolvam diretamente. É importante ensiná-la a se manter atenta, em constante estado de vigilância, para que ela perceba o que está a sua volta, os obstáculos, as pessoas, a pressão que as coisas exercem sobre o seu corpo. Ensiná-la desde cedo a desenvolver a habilidade de associar fatos e ideias, as analogias de sons e imagens, a interpretação dos silêncios.

Juliana nasceu em uma pequena cidade do Sul. Bebê prematuro, perdeu a visão na incubadora. Aos 33 anos, relata a maneira como começou a perceber a sonoridade de sua casa:

Quando eu era pequena não tinha relógio em braille, nem relógio que fala, né? Então tinha um relógio que batia as horas: blém, blém. Quando meu avô acordava, os quartos eram em cima, a primeira coisa que ele fazia era dar corda no relógio. Eu contava as batidas para saber as horas e ele gostava disso, de ouvir eu contando as horas. Então minha avó falou que esse relógio ia ficar para mim, e ele está aqui em casa. Ele é um relógio de corda, lindissimo, antigo, quadrado, tem um vidro por fora, ai tu abre o vidro e dentro tem o ponteiro e o pêndulo. Ele é de parede. Que pena que eu não posso acertar ele. Eu tenho medo de mexer, eu nunca parei pra ver, ele não é em braille. Não sei se dá pra mexer nos ponteiros, como o de braille, que é feito pra mexer. Mas eu ainda vou mexer. Ele tem uma chavezinha que encaixa e dai dá corda. Ele bate uma vez para meia hora e a hora inteira. Dá pra ouvir do meu quarto, geralmente minha mãe que dá corda.

A descrição de Juliana propicia o entendimento de seus valores estéticos. O relógio de corda é lindíssimo porque o som dialoga com a menina; traz o valor do reconhecimento e o amor do avô, que identifica a neta contando as batidas das horas; é agradável ao tato, permitindo o reconhecimento de outros elementos como ponteiro e pêndulo. Também informa sobre texturas, formas, linhas, volumes; indica a localizaçáo dos cômodos da casa; compóe suas memórias e a cada badalada lhe sussurra temporalidades.

Condillac ${ }^{17}$ pondera que "todos os nossos conhecimentos e todas as nossas faculdades vêm dos sentidos, ou, para falar mais exatamente, das sensaçóes". Segundo o autor, os sentidos se constituem

17 CONDILLAC (1715-1780) filósofo, psicólogo, economista, defensor e divulgador das ideias de John Locke (16321704). Foi amigo de Jean-Jacques Rousseau e dos demais enciclopedistas, liderados pelo editor Denis Diderot. 


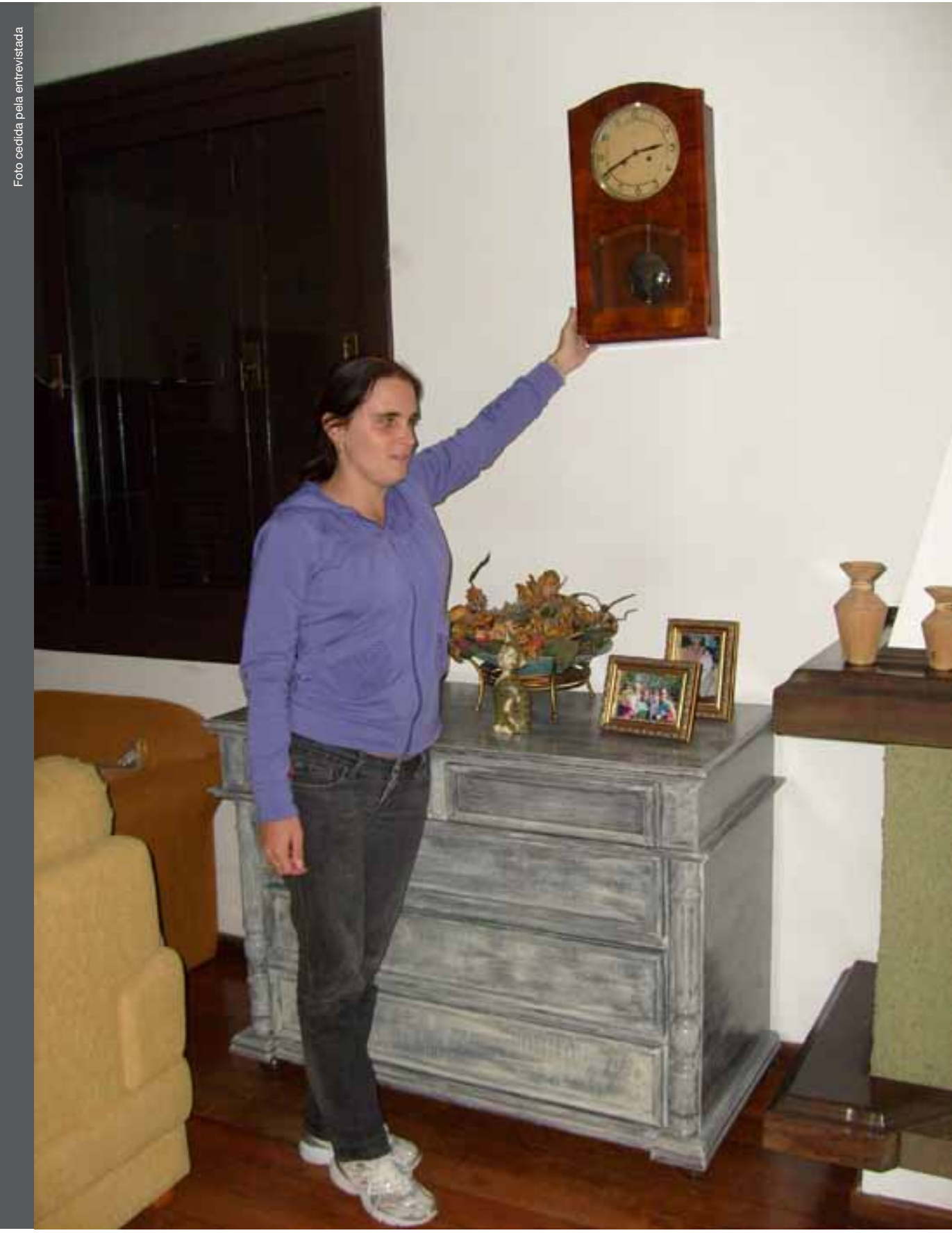

Do seu quarto, Juliana ouve as batidas do relógio 
em causa ocasional; é a alma que sente e é das sensaçóes que ela extrai todos os seus conhecimentos e todas as suas faculdades. O Tratado é dividido em quatro partes, nas quais Condillac discorre sobre os sentidos, afirmando que "o tato é o único sentido que julga por si mesmo os objetos exteriores".

Ele compara o peso que têm os sentidos, expondo que, quando todos os sentidos são estimulados ao mesmo tempo, damos menor atenção à visão, enquanto que, se apenas a visão é estimulada, a sensação da visão, ou seja, o enxergar, aí sim, se transforma em atenção. Uma sensação é atenção, comenta ele, porque é mais viva que todas as outras e quando nos fixamos em um objeto, da mesma maneira que lhe concedemos atenção, dele recebemos a própria atenção que lhe concedemos. Assim, a nossa capacidade de sentir dividir-se-á entre passado e presente, ou seja, as sensaçóes que já sentimos e das quais nos lembramos quando elas novamente se fazem presentes, esta assumindo o nome de sensação, enquanto aquela passa a se chamar "memória”. (CONDILLAC, 1993, p. 36)

\section{Aceitar... ou aceitar}

Jean (pseudônimo) tinha 50 anos quando o oftalmologista lhe disse que dentro de três meses ficaria cego. Em pânico, saiu às ruas para, sistematicamente, começar a observar fixamente as imagens, uma a uma. A sua ideia era tentar criar na memória um arquivo do que em breve não poderia mais enxergar: montanhas, mar, copas das árvores, edifícios, modelos de carros, um trem em movimento. Perdeu a visão três anos mais tarde. ${ }^{18}$

Uma das tantas mudanças na vida de quem perde a visão é que o ruído dos seus passos, de caminhante solitário, passa a ser acompanhado do tec-tec característico da bengala. Jean não tinha bengala, dizia que não precisava dela, já que saía sempre acompanhado de alguém. Na verdade, não queria usá-la: em suas próprias palavras, com a bengala todos perceberiam que ele era cego. Aos poucos foi aceitando a sua condição e passou a usar a bengala para sair, prescindindo do acompanhante.

Para muitas famílias, administrar a ideia da cegueira já é difícil no âmbito familiar. Kuusisto descreve como foi criado sabendo que era cego, mas ensinado a negar a condiçáo. Refletindo o complexo e a negação da mãe em relação à deficiência, caminhava atordoadamente sem fazer uso da bengala, envergonhando-se da sua condição. A palavra cego era raramente pronunciada em sua presença e, aponta,

18 Em 1995 criei para Jean um sistema de ensino de braille ampliado, com as palavras da sua nova profissão. Com 58 anos, atuando em jornalismo, com a perda da visão teve que abandonar a profissão. No início, enviei pelo correio palavras escritas em braille em papel cartão com ilhoses. Facilmente ele entendeu as 64 combinaçóes dos seis pontos do braille; a partir de então passei a reduzir o tamanho dos pontos. Fiz colagens de sementes, de missangas e de sementes ainda menores, um desafio para os seus dedos pouco habituados às pequenas texturas. Não demorou para que conseguisse ler o braille em seu formato regular. 
sua mãe tinha relegado a palavra cego ao mesmo departamento da palavra câncer (KUUSISTO, 1999, p. 7, tradução minha).

Pedro ${ }^{19}$ também relata a não aceitação da deficiência:

Na infância eu já não enxergava no escuro e minha família não aceitava bem a minha deficiência. Eu não estava equipado, psicologicamente, para lidar com a situação de bailinho, por exemplo, não tinha a menor condição de dizer para uma garota "eu não enxergo aqui nesse escuro, mas eu te acho muito bonita, eu te vi ali no claro, $e$ te achei muito bonita, quer dançar comigo?" Eu não tinha condiçóes para fazer isso, minha família negava totalmente a minha deficiência, não falava nada para ninguém, eu não podia declarar a situação porque a minha família escondia até de parentes e tudo, e eu também achava que devia esconder. Começar a dançar sem enxergar, eu, dançando com uma garota, começava a girar, e já não sabia se estava de frente ou não. Em casa eu adoro dançar, cantar junto, fazer ginástica ouvindo música...

Masini ${ }^{20}$ reflete como a relação com os pais forma o autoconceito da criança. "Ele será positivo, quando a mãe, ou o pai, ou ambos, confirmam a existência da criança, isto é, quando respondem de forma pertinente, ou sintonizada, à ação iniciada pela criança” (MASINI, 2007, p. 28). Nesse sentido, Queiroz $^{21}$ relata como o seu pai sempre procurou convencê-lo de que era uma criança comum, não para camuflar suas condiçóes, mas para apoiá-lo em sua doença. Diabético desde criança e com perda da visão na vida adulta em consequência da doença, negava-se a aceitar as limitaçóes da doença comendo todo o tipo de guloseimas, refrigerantes. "Vejam, estou tomando coca-cola, sou igual a todo mundo". Trancava-se no banheiro para comer escondido, mas na frente do espelho, os doces das festas. E relata o ocorrido em uma festa, quando um colega lhe ofereceu jujubas:

Aceitei e papai estava olhando para mim. Senti vontade de colocar todas as jujubas de uma vez na minha boca, mas antes de fazer o gesto olhei para ele. Sua expressão estava tão triste que me paralisou. Abri a mão devagarinho, deixando que as jujubas caíssem

19 Pseudônimo

20 MASINI, Elcie F. Salzano (org.) A pessoa com deficiência visual. São Paulo : Vetor, 2007

21 QUEIRÓZ, Marco Antonio de. Sopro no corpo. São Paulo : Círculo do Livro, 1986 
uma a uma no chão. Ele se aproximou de mim e me abraçou carinhosamente; me levantou em seus braços e apoiou a minha cabeça em seu ombro, enquanto me afagava. Chorei por vê-lo tão triste por minha causa, mas ao mesmo tempo, estava feliz porque, daquela forma, eu estava recebendo tudo o que queria: um abraço, um carinho, um amigo. (QUEIROZ, 1986, p. 130)

\section{Eu, cidadáo, por detrás destes olhos}

Sabe como eu me imagino no espelho?

É como se eu estivesse colada lá.

E quando passo a mão e sinto o vidro, eu sei que estou lá atrás.

Juliana

Em Diderot (2000) temos a descrição do espelho feita por uma pessoa cega:

Perguntei-lhe o que entendia por espelho. Uma certa máquina, respondeu-me, que póe as coisas em relevo longe de si mesmas, se se encontram situadas convenientemente em relação a ela. É como a minha máo, que não preciso pousar ao lado de um objeto a fim de senti-la. Descartes, cego de nascença, teria que, parece-me, felicitar-se com semelhante definição. Com efeito, considerai, eu vos peço, a finura com a qual foi mister combinar certas ideias para chegar a ela. Nosso cego só tem conhecimento dos objetos pelo tato. Sabe, pelo relato dos outros homens, que por meio da vista a pessoa conhece os objetos assim como eles lhe são conhecidos pelo tato; ao menos é a única noção que pode formar deles. Sabe, ademais, que não se pode ver o próprio rosto, conquanto se possa tocá-lo. A vista, deve ele concluir, é portanto uma espécie de tato que se estende apenas aos objetos diferentes de nosso rosto e afastados de nós. Aliás, o tato lhe dá ideia apenas do relevo. Portanto, acrescenta, um espelho é uma máquina que nos póe em relevo fora de nós mesmos. (DIDEROT, 2000, p. 98) 

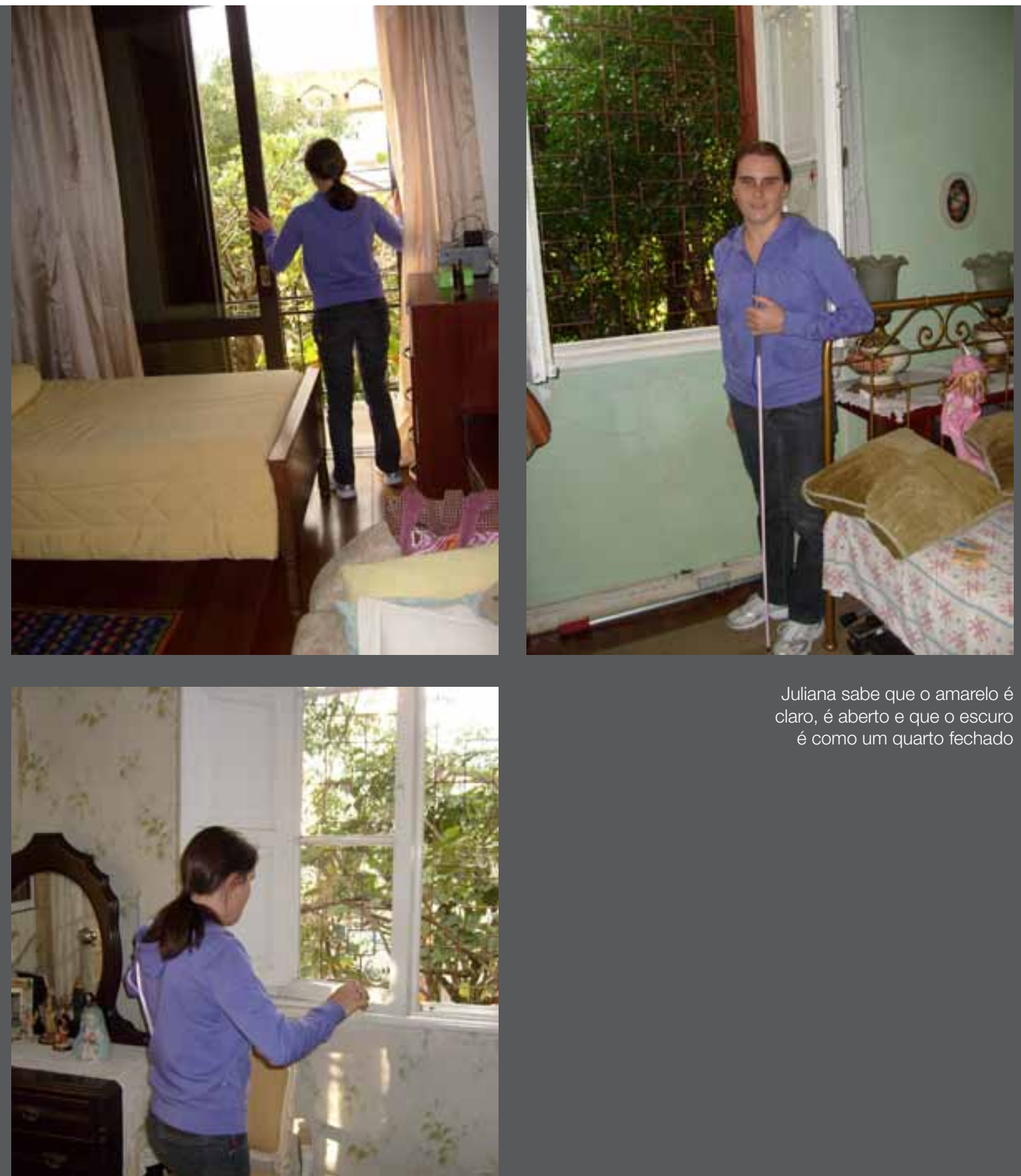

Juliana sabe que o amarelo é claro, é aberto e que o escuro é como um quarto fechado 
Perder a visão significa, obrigatoriamente, reestruturar a vida de maneira diversa. Encher um copo de água, tarefa simples antes executada distraidamente, agora passa a ser um exercício de ouvir o líquido completando o espaço vazio do copo. O desafio é combinar o som com o tamanho da sede. Assinar um documento, ou um cheque, implica em usar sobre o papel uma máscara com janelas dentro das quais se pode escrever. Chamar o garçom torna-se difícil, um exercício de paciência; cardápio, só em braille, se a pessoa com deficiência já tiver adquirido o conhecimento da escrita tátil e se o restaurante proporcionar a facilidade. O ritmo da vida muda, tudo é feito com mais cuidado, mais devagar. Usar banheiro público é depender de acompanhante, é preciso "decidir confiar em um estranho"22. É preciso aprender a lidar com o preconceito.

Os protagonistas nos mostram que a percepção da natureza extrapola a apreensão visual. Com elas aprendemos que a chuva esculpe as formas; que o vento, além de alterar a temperatura da pele, cria cenários; que as texturas dialogam com os cidadãos; que as memórias têm diferentes perfumes. Juliana explica o que é a natureza para ela.

Gosto da natureza, tenho curiosidade de saber como são acidentes geográficos, como é montanha, vale, mas posso muito bem viver sem ver tudo na vida. É tanta poluição de ver que as pessoas param de sentir... As pessoas me perguntam se eu não sinto tristeza de não ver as coisas; é claro que sinto vontade de ver o céu, as cores. Sei que o amarelo é claro, é aberto, entra vida e sol. O escuro é como um quarto fechado. Eu sinto o pôr do sol, eu sinto a energia.

A maneira sensível como a jovem descreve a sua percepção está na fala de tantas outras pessoas que não usam os olhos para vivenciar a natureza. Juliana diz: Eu não imagino um carro inteiro, primeiro vejo uma porta, depois a outra porta; eu sei como ele é inteiro, mas eu não vejo ele inteiro.

Outrossim, Helen Keller expóe a sua percepção do todo:

Meus dedos não podem, é claro, obter a impressão do todo, de imediato; mas eu sinto as partes, e minha mente as coloca junto, as une. Eu caminho pela minha casa tocando objeto por objeto, em ordem, antes de formar uma ideia completa da casa. Em outras casas eu posso tocar apenas o que me é apresentado, os principais objetos de interesse,

22 KUUSISTO, Stephen. Planet of the blind - a memoir. New York : Delta, 1999 


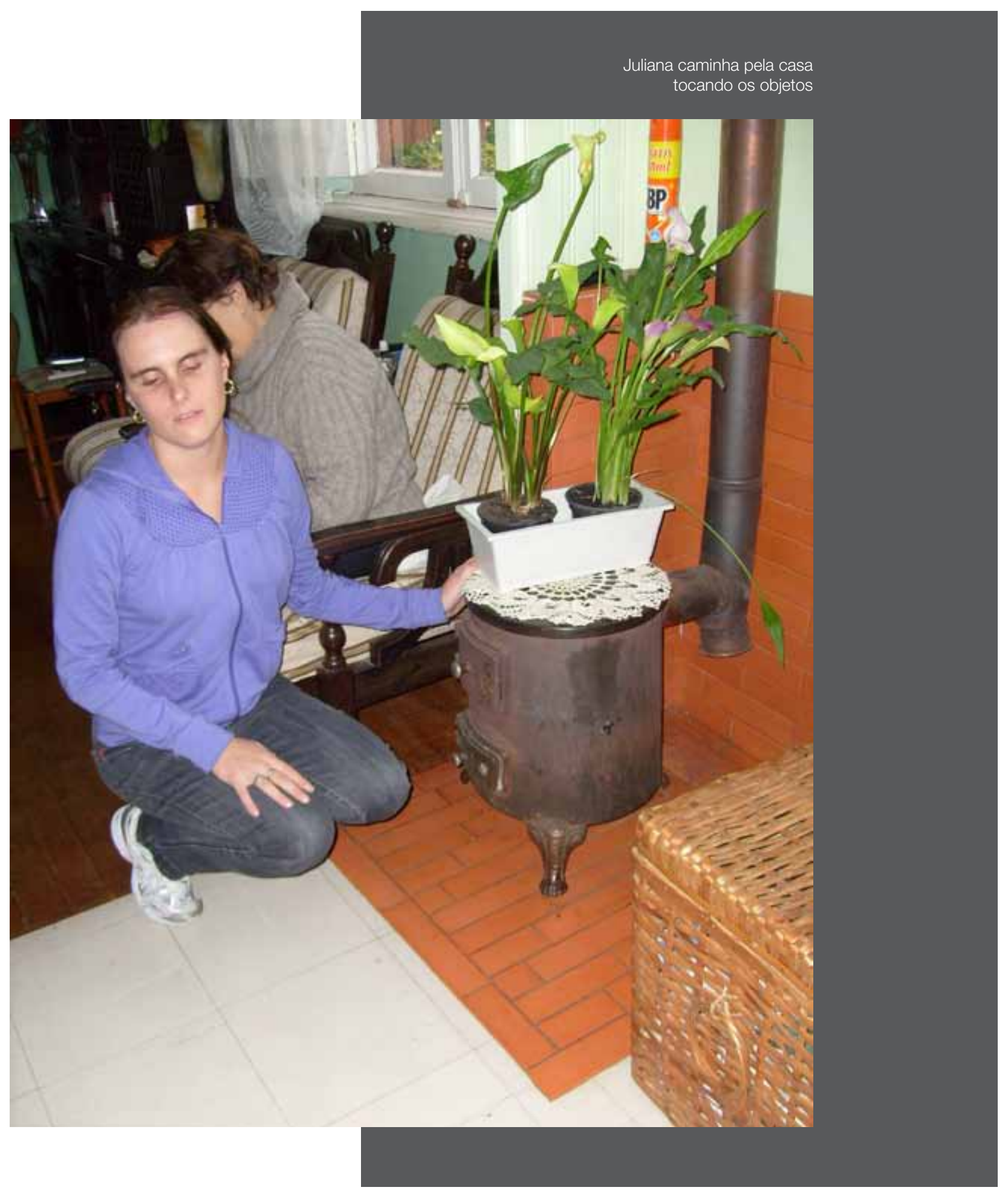




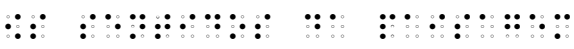

entalhes na parede ou curiosidades arquitetônicas exibidas como um álbum de família. Portanto, a casa não familiar não tem a princípio, para mim, um efeito geral ou uma harmonia de detalhes. Não há uma concepção completa, mas uma coleção de impressóes de objetos os quais, na medida em que chegam para mim são desconexas e isoladas. Mas, minha mente é cheia de associações, sensações, teorias e com elas eu construo a casa. (KELLER, 2009, p. 4, tradução minha)

Sacks questiona: "Até que ponto somos os autores, os criadores das nossas sensaçôes? [...] Ficar cego, especialmente em uma fase avançada da vida, traz um desafio colossal, potencialmente esmagador: encontrar um novo modo de viver, de ordenar o mundo pessoal, quando o velho mundo foi destruído" (SACKS, 2010, p. 179). O médico inglês passou a compartilhar as angústias e inseguranças dos seus pacientes depois que um câncer, em um dos seus olhos, o levou à condição de paciente. Observar a paisagem com apenas um olho subtraiu-lhe a visão estereoscópica, a distância que podia perceber entre os objetos. Agora, ao tentar pegar um objeto sobre a mesa, percebe sua mão agarrando o ar. Já errou um copo por quase trinta centímetros de distância e derramou vinho sobre um colega.

Os degraus da escada transformaram-se em meras linhas traçadas paralelas. Objetos no chão, como um jornal ou um capacho podem parecer erguidos no ar e provocar susto ao serem confundidos com uma mesa. "Quando vou ao Jardim Botânico”, relata ele, “já não posso fitar, como antes adorava fazer, a densa folhagem das árvores e arbustos e ver camada após camada, profundidade após profundidade - agora é tudo uma confusão plana. [...] Outro dia vi um fiapo na lente dos óculos e tentei removê-lo, e então me dei conta de que o fiapo era uma folha na calçada." (SACKS, 2010, p. 168-170).

O neurologista explica que o córtex visual, privado da entrada de informaçóes provenientes da visão, passa a clamar por novas funçóes. E relata como um de seus pacientes "vê" o braille enquanto lê com a ponta dos dedos, reconhece pessoas pelo cheiro que têm e consegue captar estados de tensão ignorados até pela própria pessoa. (2010, p. 204).

A falta da visão exacerba a atenção para outros sentidos, ativando a sua interação. Helen Keller expóe a ideia de distância que o odor lhe propicia:

Devo chamar de horizonte a linha onde odor e imaginação se encontram no limite mais distante do olfato. O toque parece residir no objeto tocado, porque há o contato com as superfícies. No olfato não há noção de relevo e o odor parece não residir no 
objeto cheirado, mas no órgão. Como posso sentir o cheiro de uma árvore a distância, é compreensível para mim que uma pessoa veja a árvore sem tocá-la. Não acho complicado compreender. Não me confunde o fato de alguém receber a árvore como uma imagem em sua retina, sem relevo, já que o meu olfato recebe a árvore como uma esfera delgada, sem conteúdo. Por si, o odor nada sugere. Preciso aprender por associação a fazer julgamentos de distância, lugar, açôes ou do entorno, da mesma maneira como as pessoas julgam a cor, a luz, o som. (KELLER, 2009, p. 28-30, traduçáo minha)

Se para videntes os signos podem ser indicadores visuais que contribuem para aprofundar o conhecimento, para pessoas que não enxergam com os olhos o conhecimento é transmitido de maneira diversa. Por meio da emanação, Helen Keller conseguia aprender sobre as pessoas, podendo mesmo dizer o tipo de trabalho que elas exerciam:

Os aromas de madeira, ferro, tinta, e medicamentos se agarram nas roupas de quem trabalha com eles. Assim, posso distinguir um marceneiro de um ferreiro, um artista de um pedreiro ou químico. Quando uma pessoa passa rapidamente de um lugar para outro eu obtenho a impressáo olfativa de onde ela esteve - na cozinha, no jardim, no hospital. (KELLER, 2009, p. 30, tradução minha)

Milligan (MAGEE; MILLIGAN, 1995, p. 55) descreve a chamada visão facial, dizendo que ao caminhar em áreas externas, objetos que estão à altura de sua cabeça afetam a corrente de ar que alcança a face, o que auxilia na sua identificação. Sons excessivamente fortes, ou a surdez, parecem suprimir essa capacidade - nesse sentido percebemos grande diferença de comportamento das pessoas cegas em relação às surdacegas. Em uma área interna nunca antes visitada, o conhecimento da pessoa cega com boa audição não fica restrito ao que ela pode tocar, ou aos objetos sonoros. Milligan elucida que no momento em que entra em um cômodo, pode dizer das suas dimensóes, e se está vazio ou cheio de móveis.

Pessoas cegas com audição normal são capazes de "ouvir” os objetos que estão próximos das mãos, desde que não estejam muito próximo do chão. São capazes de "ouvir" também algo sobre a forma do entorno. O filósofo relata que ele próprio “ouve” postes de iluminação, carros estacionados com motor desligado e, conforme caminha, nota que esses objetos adensam a atmosfera e fazem reverberar os sons dos passos, da varredura da bengala, dos outros sons da vizinhança. Diferentes objetos transmitem sutis diferenças de informaçáo. Por exemplo, caminhar ao lado de uma cerca viva soa diferente do que 
caminhar ao lado de um muro de tijolos, informa ele. E é possível, com a ajuda desse sentido, conhecer a altura dos objetos, sem tocá-los.

Videntes também têm a capacidade de discernir, de olhos fechados, se o cômodo é grande ou pequeno, vazio ou lotado de objetos. Um túnel estreito totalmente escuro, provoca nas pessoas que enxergam com os olhos, sensaçóes diferentes das produzidas em uma área ampla. No entanto, pessoas cegas têm muito mais oportunidade do que videntes de vivenciar situaçóes dessa natureza.

Os conhecimentos têm três portas para entrar em nossa alma, e nós mantemos uma delas trancada, por falta de sinais. Se se houvesse negligenciado as duas outras, estaríamos reduzidos à condição dos animais. Do mesmo modo que só dispomos do apertar para nos fazer entender pelo sentido do tato, teríamos apenas o gritar para falar ao ouvido. Senhora, é preciso carecer de um sentido a fim de conhecer as vantagens dos símbolos destinados aos que restam; e pessoas que tivessem a desgraça de ser surdas, cegas e mudas, ou que viessem a perder esses três sentidos por qualquer acidente, ficariam muito encantadas se existisse uma língua nítida e precisa para o tato. (DIDEROT, 2000, p. 109)

Se, por um lado, dominar o espaço interno da casa pode ser tarefa relativamente fácil para a pessoa adulta que perde a visão, o desafio de sair de casa desacompanhado pode amedrontar e até constituir impedimento. Não é o que acontece, no entanto, com alguns dos protagonistas da pesquisa que mostraram muita facilidade para memorizar ruas e trajetos. Um deles é Hélio, que sabe de cor os nomes das ruas e o entorno dos percursos que faz. Sua mulher, Marlene, relata que muitas vezes no ônibus, Hélio se prontifica a ajudar passageiros que pedem ao motorista informações de ruas que ele não conhece. Difícil, no entanto, explica ela, é convencer o passageiro de que a informação está correta, já que a pessoa, vidente, parece não acreditar que uma pessoa cega possa conhecer a cidade.

Ronaldo, engenheiro de 59 anos, é outro protagonista que conhece bem a cidade. Em uma manhã de fim de semana de feriado prolongado em São Paulo ${ }^{23}$ visitei com Ronaldo o Centro Histórico da cidade. Iniciamos com uma visita ao seu local de trabalho, a Secretaria da Fazenda, à Avenida Rangel Pestana, 300. Ronaldo comenta as barreiras e dificuldades ao adentrar o prédio: colunas, vasos, painéis de exposição, sinalizadores de metal com fitas para organizar filas.

23 Visita feita no dia 24 de junho de 2011, sexta-feira 



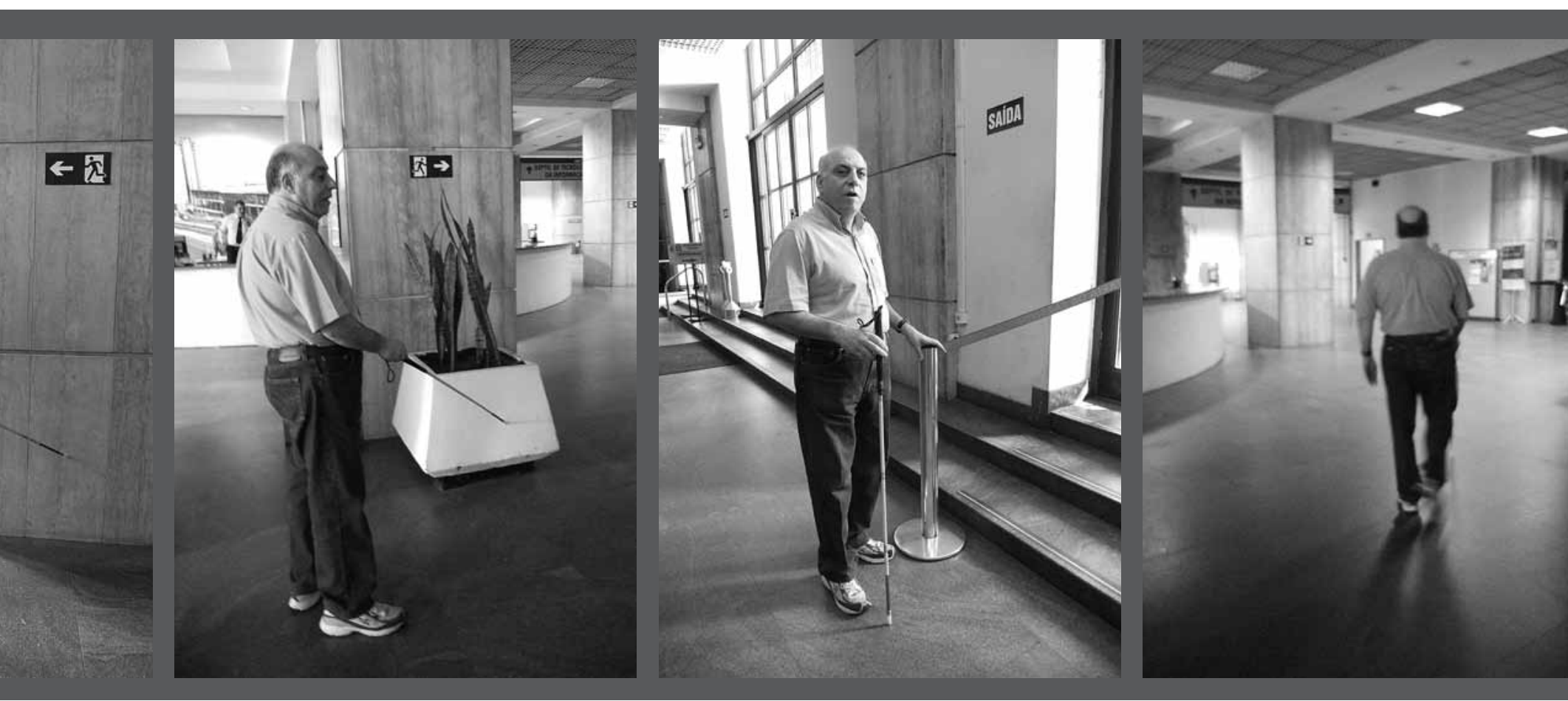

Apesar da amizade e camaradagem já desenvolvida com os funcionários, não há nenhuma capacitação do pessoal de apoio para o trato com a pessoa com deficiência. Assim, são comuns situações em que os funcionários não sabem como agir. Ronaldo relata que o saguão de entrada é lavado periodicamente. Se ele chega ao local em uma dessas ocasióes, percebe o pânico das faxineiras, e as expressóes: “Ai, meu Deus!”, “Nossa Senhora!”, "E agora?”, embora ninguém tome a iniciativa de ajudá-lo. Assim, muitas vezes já chegou a chutar baldes e tropeçar em rodos e vassouras.

Saímos do prédio para Ronaldo apontar as dificuldades e barreiras que encontra ao caminhar com amigos no seu horário de almoço. As barreiras estáo por todo lado, na frente do prédio, no ponto de ônibus. Descendo a Rangel Pestana em direção à rua D. Pedro II, um dos trajetos de Ronaldo, encontramos um estreitamento de rua onde a localizaçáo imprópria de um poste mal permite a passagem de duas pessoas. O sentimento é de desconforto e de desagrado com o descaso dedicado ao desenho da cidade.

Guiados pelo engenheiro, voltamos pela própria Rangel Pestana e atravessamos a avenida. Ronaldo mostra uma grade no chão, usada de referência como local de espera do ônibus. Qualquer detalhe de textura pode ajudar na identificação de um espaço ou direção e noto que a bengala de Ronaldo esquadrinha todas as minúcias. Descendo pela Rua Dr. Bitencourt Rodrigues, Ronaldo aponta as dificulda- 


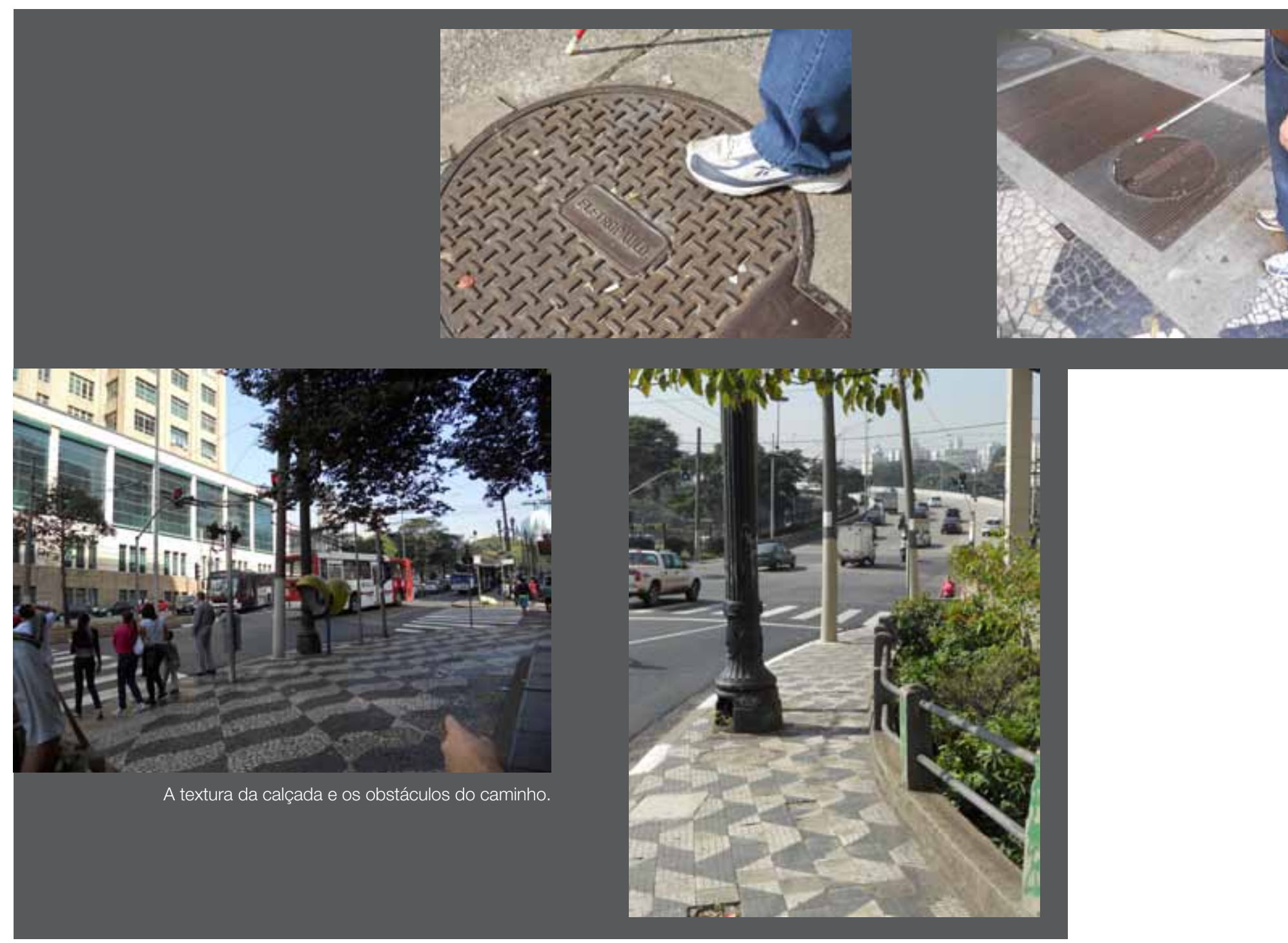




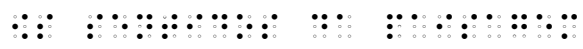

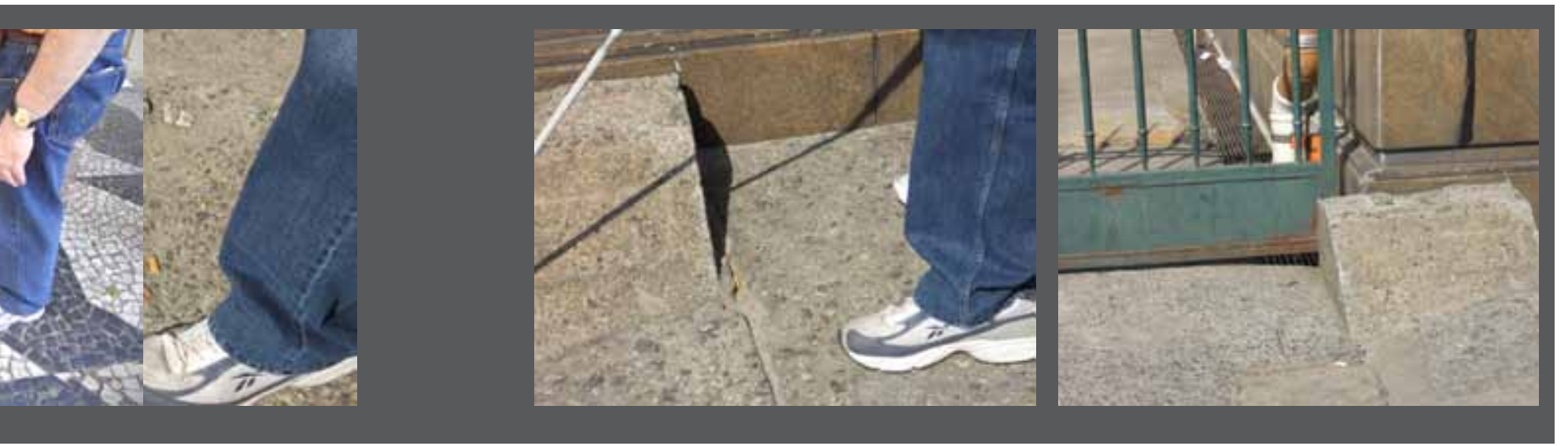

des para entrar no ônibus, que costuma parar longe da calçada, assim como os obstáculos encontrados no caminho.

Cruzando a Rua do Carmo, passamos em frente ao Corpo de Bombeiros. A caminho da Praça Joáo Mendes, pela Rua Tabatinguera, cruzamos a Avenida da Liberdade. Neste trecho, alerto Ronaldo para o perigo de bater a cabeça em um "orelhão" 24 .

Depois do almoço na padaria Santa Tereza, à Praça João Mendes, 150, ainda guiados por Ronaldo, seguimos pela lateral da Catedral da Sé. Cruzamos toda a Praça da Sé e Ronaldo alerta: na bifurcação, vamos pegar à direita, a rua Quinze de Novembro. E à direita novamente, pela Rua Anchieta, chegamos ao Pátio do Colégio. O caminho é trilhado com extrema facilidade. Ronaldo aduz a teoria de Merleau-Ponty (1994, p. 182) e percebe o espaço como se cada rua, cada esquina e cada edificaçáo estivessem relacionadas a "mil coordenadas virtuais", como se caminhasse dentro da própria casa, passando da sala para o quarto, para o banheiro, percebendo à frente uma janela, ou ao lado um sofá. Reconhece aquela área da cidade como reconhece a voz de um amigo.

24 Criado em 1971 pela arquiteta Chu Ming Silveira, e com desenho inspirado na forma do ovo, de acústica perfeita, o popularmente conhecido "orelhão" pode ser encontrado em muitas das cidades brasileiras. É considerado pelas pessoas cegas como um dos obstáculos mais ameaçadores, por náo poder ser detectado pela bengala e atingir diretamente a cabeça. 

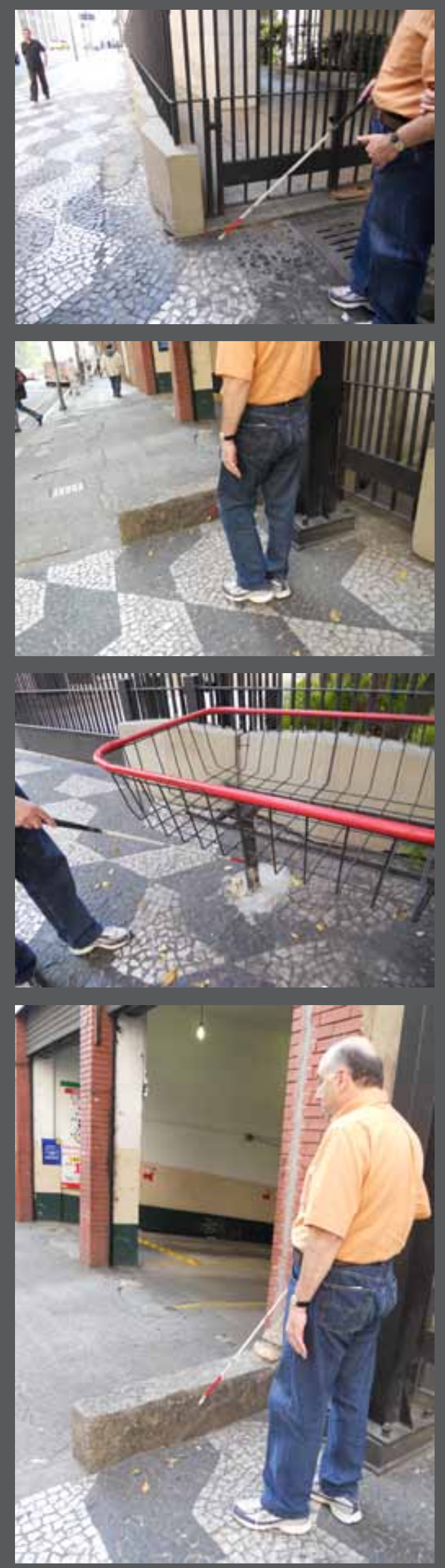
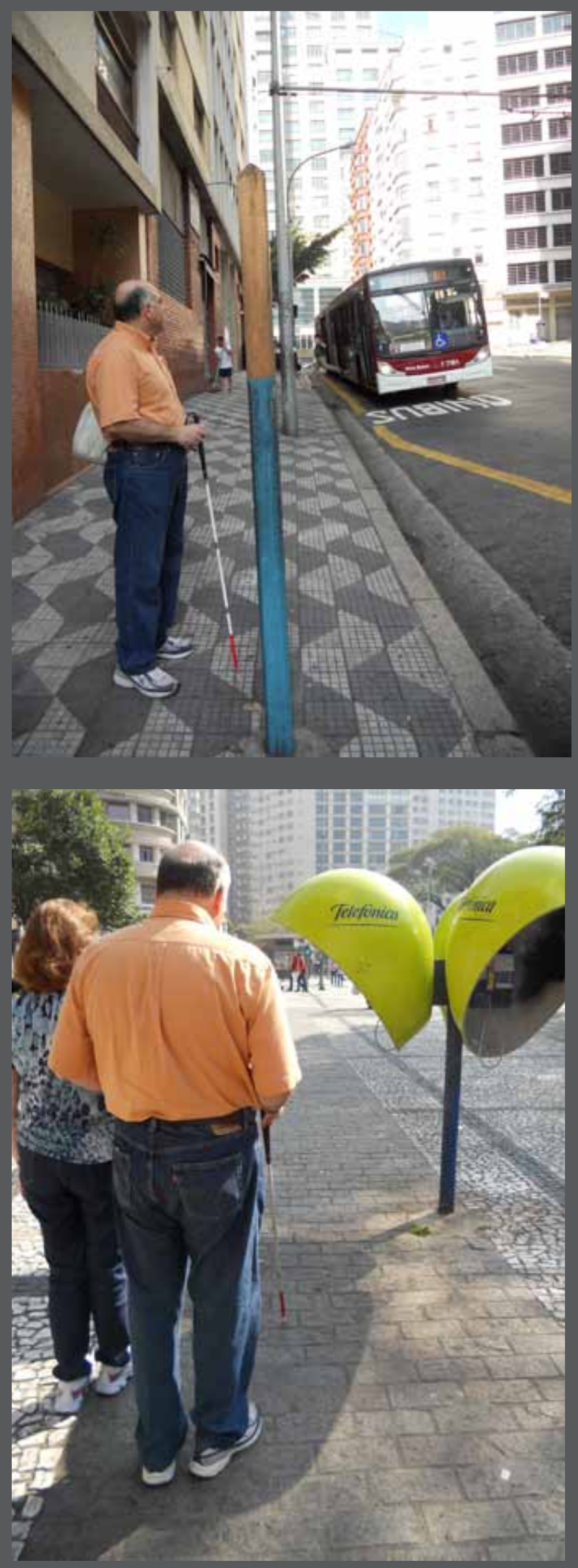

Um dos obstáculos mais ameaçadores, o "orelhão" atinge diretamente a cabeça da pessoa cega. 


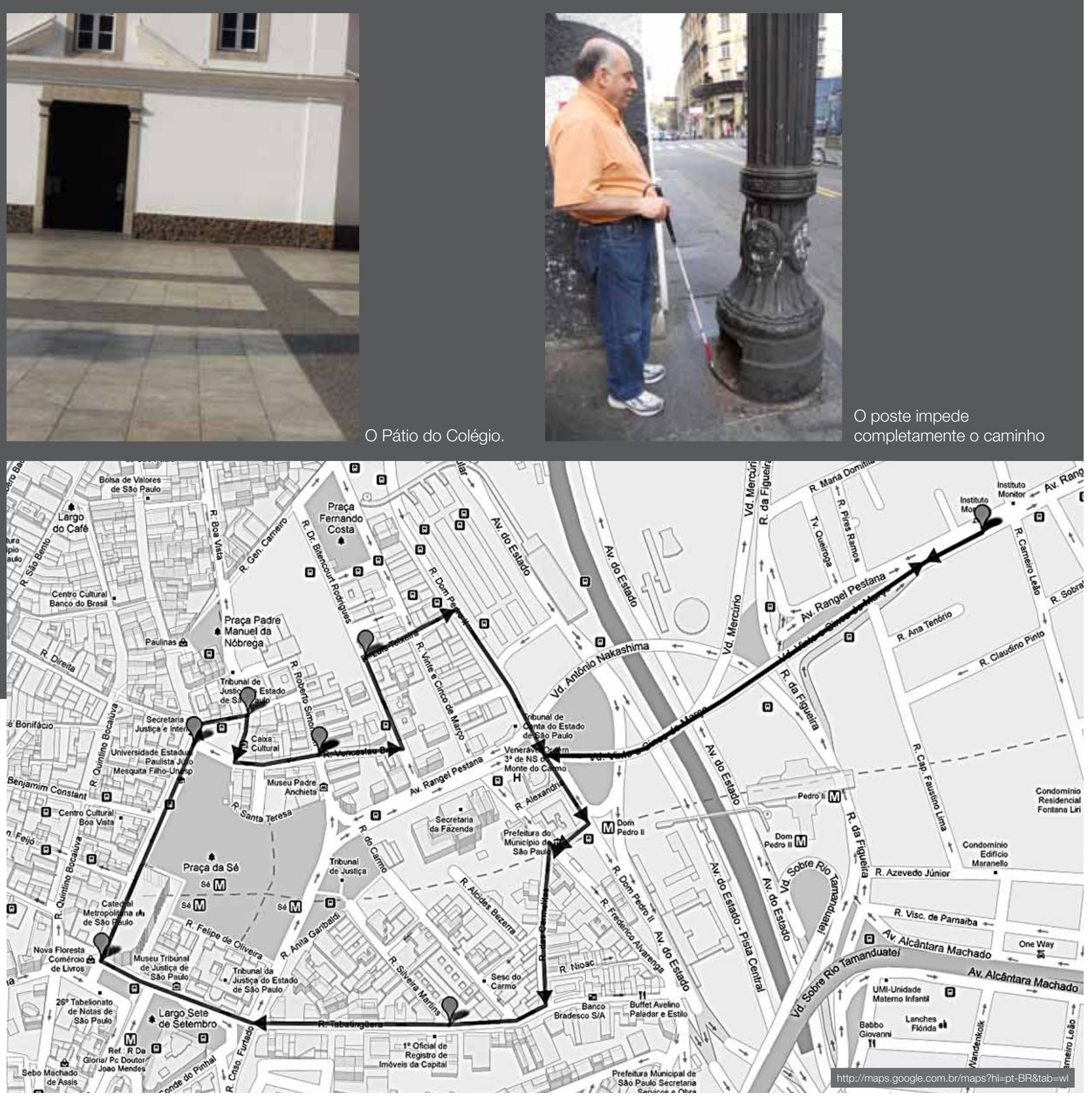

Depois do café no Pátio, Ronaldo segue como se tivesse um roteiro impresso na memória. Voltamos pela Rua Anchieta, lateral do Pátio do Colégio, e viramos à direita na Rua Roberto Simonsen. Desviando de obras e de famílias de moradores de rua, chegamos à esquina da Rua Roberto Simonsen, onde um poste ocupa completamente o caminho. Novamente a constataçáo da impropriedade e do desagrado de ser cidadáo em uma cidade que náo acolhe. 
Passamos por uma pequena mercearia à Rua Venceslau Brás, 81, onde Ronaldo com frequência compra frutas e é carinhosamente recebido; mais adiante paramos na casa lotérica e entâo chegamos de volta à Rua Bittencourt Rodrigues. Encerramos o passeio subindo até a Avenida Rangel Pestana, onde pegamos um táxi para casa.

\section{A hegemonia da visáo e o peso da diferença}

A maioria dos cidadáos comuns não sabe conviver com o diferente. Vidente, não convive com pessoas cegas, não sabe como interagir com a deficiência visual. Entende que as poucas açóes de acessibilidade adotadas nas grandes cidades são efetivas, eficazes, suficientes para assegurar o acesso de qualquer pessoa a qualquer local. Não considera como barreiras os orelhões, as imperfeições no piso, os galhos de árvores que ultrapassam os muros dos jardins das residências e se debruçam sobre as calçadas; as mesas de bares que invadem o espaço do pedestre, o mobiliário urbano que, muitas vezes longe de facilitar, impede a caminhada. Surpreende-se com a informação de que pessoas cegas trabalham com computador, namoram, casam-se, cuidam da casa e dos filhos, assistem à televisão, cozinham suas próprias refeições, viajam nas férias, como qualquer cidadão que enxerga com os olhos.

A nossa cultura privilegia de tal modo a percepção visual que os cidadãos tornam-se reféns das imagens e não conseguem imaginar a vida sem enxergar com os olhos. Consideram que as pessoas cegas vivem no mundo das trevas e afirmam que seria preferível perder qualquer coisa a perder a visão (MAGEE; MILLIGAN, 1995, p. 48). Milligan (1995, p. 46) reflete sobre as desvantagens da cegueira: náo ser capaz de fazer contato visual, expressar-se com uma piscadela ou um levantar de sobrancelhas, sinalizar com um encolher dos ombros, ou com um sorriso e outros meios de comunicação tão comuns para as pessoas videntes.

Pessoas cegas, no entanto, têm um sentido de simultaneidade, têm a capacidade de considerar uma situação como um todo e integrar detalhes dentro de uma cena, fazendo uma síntese dos elementos. Por usarem predominantemente a visão, videntes não percebem que há à disposição uma quantidade enorme de informaçóes redundantes, não apenas para o sentido da visão, mas propiciadas a todos os sentidos. A maior parte dos videntes fica um pouco nervosa quando do primeiro encontro com a pessoa cega e tende a tratar essa pessoa como se a deficiência visual estivesse associada à deficiência mental, ou com insuperáveis problemas de comunicação (MAGEE; MILLIGAN, 1995, p. 50).

Lembro aqui a reflexão da psicóloga Lígia Assumpção Amaral no III Congresso Brasileiro sobre Educação Especial, em 1999: 


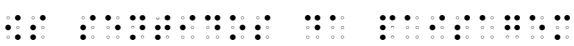

[...] acredito firmemente que a diferença pode, na maioria das vezes, passar de elemento dificultador para mola propulsora de novos conhecimentos, de crescimento individual e coletivo. Ou seja, vejo a diferença tendo o poder de levantar indagaçóes e de desorganizar - o que propicia, concomitantemente, novas formas de organização, sejam elas intrapsíquicas ou interpessoais. É mais ou menos o mesmo que falar do estranhamento e das novas configuraçôes que ele provoca.

A protagonista Roseli, que atua em um grupo de teatro, reflete:

Quando você começa a entender o universo do outro você já não faz as mesmas suposiçóes que você fazia antes, sem conhecer. Você começa a perceber que, para a pessoa cega, você tem que descrever algumas coisas que existem nas ruas, ou detalhes dos prédios, senão ela não vai saber o que tem lá. Você começa a se tocar de umas realidades que antes você não tinha noção.

Em seus depoimentos, os protagonistas da pesquisa relatam inúmeras situaçóes que revelam a incompreensão da deficiência visual, como, por exemplo, pessoas que falam mais alto com a pessoa cega, fazendo observaçóes como se, por ter deficiência visual, ela fosse também surda. Cidadãos que se aproximam e observam indiscretamente a pessoa cega, por acharem que ela não percebe que está sendo observada. Situaçóes em que o tratamento é infantilizado, ou quando são tratados com pena ou condescendência, como se precisassem da caridade alheia. Pessoas que mostram surpresa ao observarem situaçôes corriqueiras e fazem perguntas indiscretas sobre a intimidade da pessoa com deficiência. Em todos os depoimentos houve inúmeros exemplos que mostram a falta de informação sobre a cegueira.

Aproveitar as oportunidades para conviver com as diferenças pode propiciar crescimento pessoal e o aprendizado da percepção com o uso de todos os sentidos. A proximidade e a convivência com pessoas que têm deficiência visual trazem benefícios para pessoas videntes, assim como para as pessoas cegas. O desconhecimento total da deficiência visual, ao contrário, só aumenta a distância entre pessoas videntes e cegas e dificulta a convivência entre elas. Cabe ao cidadão que enxerga abandonar o tratamento discriminatório, as açôes de tolerância e indulgência e aproximar-se das pessoas com deficiência visual sem rótulos classificatórios, entendendo que a riqueza está na diferença. 

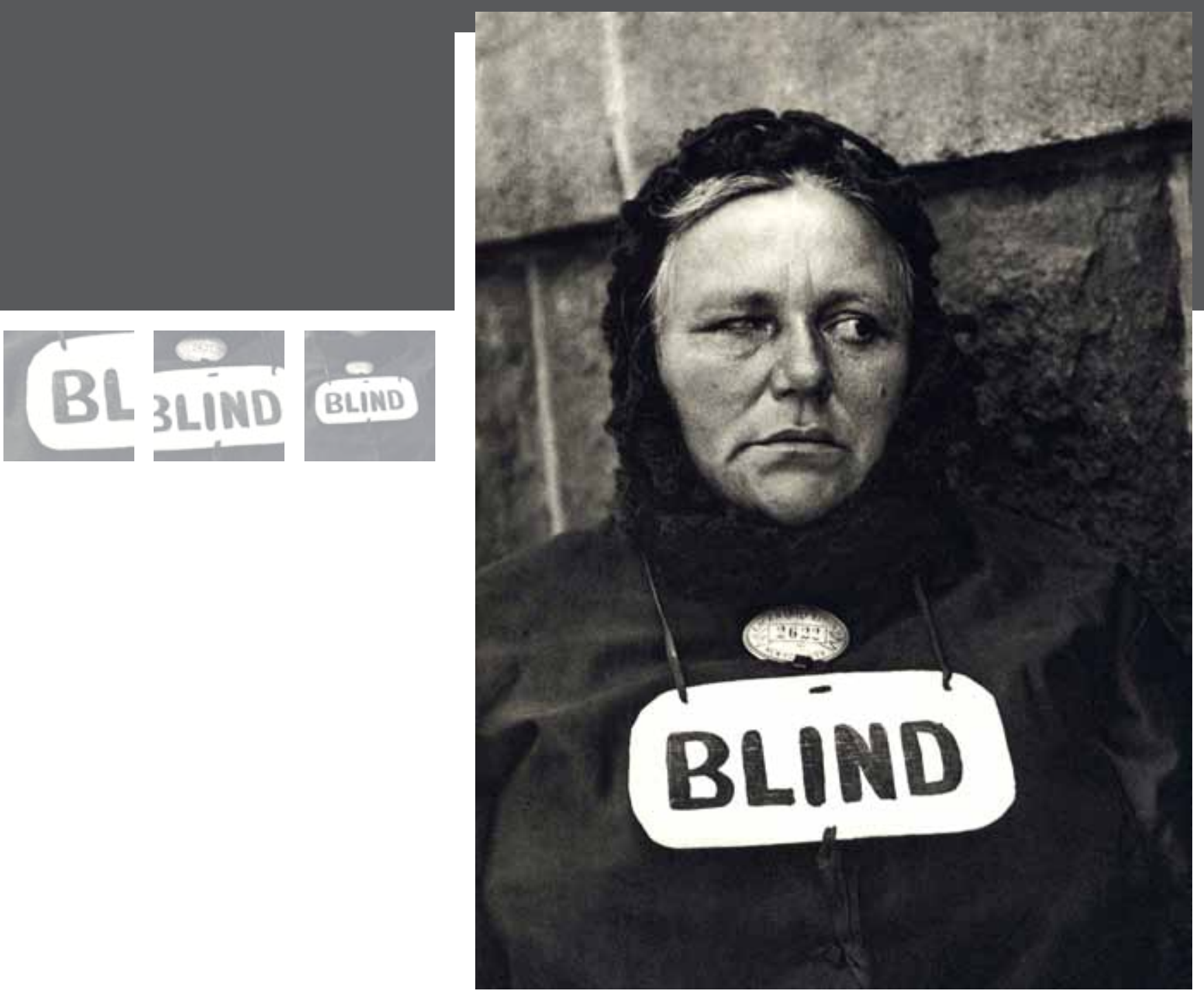

Paul Strand: Blind, 1917 (9) Aperture Foundation, Inc., Paul Strand Archive
WWW.APERTURE.ORG TTP:/MWW.APERTURE.ORG/ HTTP:/MWW.APERTURE 


\section{Preconceito}

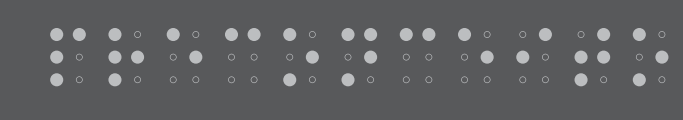

\section{Pessoas aleijadas como você deveriam servir só pra fazer sabão. ${ }^{1}$}

Escolheu o pseudônimo David para participar da entrevista, pois, assim como o protagonista da história, é pequeno e venceu, explica o assistente social de 44 anos, funcionário concursado da prefeitura de Guarulhos. Posteriormente, optou pelo nome próprio, Antonio. Toninho, como é carinhosamente chamado pela família e pelos amigos, caminha por toda a cidade de São Paulo, conhece bem o transporte público local e já sofreu todo tipo de preconceito - tem uma coleção de histórias para contar. Além de deficiência visual, Toninho tem dificuldades motoras. Em seus percursos pela cidade, ao entrar nos estabelecimentos comerciais, antes de dizer o que quer comprar ou consumir, tem que esclarecer que sua intenção não é pedir esmola. 
Toninho relata como são os seus percursos.

Moro em São Miguel Paulista e o meu trajeto é de casa até o centro de São Miguel, até a estação de trem, vou de ônibus. Costumo usar tanto a linha Metrô-Penha quanto o Parque D. Pedro. A Metrô Penha tem ônibus novos e acessiveis, agora, a linha Parque D. Pedro que sai de Vila Mara, tem uns ônibus que são totalmente inadequados, ônibus novos que são terriveis. O degrau para entrar é bom, foi feito pensando em cadeirante. Mas quando você vai sentar na cadeira é totalmente inadequada para quem tem deficiência visual, como eu.

Os obstáculos são grandes no centro de São Miguel, existe muito camelô, as pessoas não dão espaço para a gente passar e as calçadas são quebradas. Ainda existe aquela coisa da populaçâo perguntar: - Como você anda sozinho, como é que pode?

Toninho não é o único que ouve comentários assim. Fernando, massoterapeuta, 28 anos, também tem deficiência visual e faz relato semelhante:

Tem pessoas que náo sabem o que fazer. Ai, meu Deus, o cego tá vindo, o que eu faço? Não vou ficar perto dele porque eu vou pegar doença. Contagiosa.

A gente pede para ajudar eles pegam a gente pela camisa.

Uma vez me agarraram pelo pescoço: vem, moço, pode atravessar

(mostra como foi, passando o braço em volta do pescoço, de maneira brusca).

Outro dia, eu queria uma informação e disse:

- Por favor, o senhor pode me ajudar?

E a pessoa falou:

- Eu não tenho dinheiro, não.

Eu disse:

- Eu não quero dinheiro, eu quero saber o letreiro do ônibus, eu trabalho.

E ele:

- Imagina, cego trabalhar.

Tirei o crachá da empresa e falei:

- LEIA.

A pessoa viu, saiu andando. Eles acham que deficiente visual só serve para bater perna, vagabundear, pedir... 
Relata um episódio acontecido em uma das vezes que voltava para casa:

Uma vez eu estava no trem, indo para a minha casa, senti alguém mexendo no bolso da minha camisa. Quando eu vejo o cara colocou no meu bolso uma nota de R\$ 50,00. Pela cor e pelo ampliado atrás, consigo enxergar. Ai, cheguei em casa, minha máe falou: - Onde você arrumou $R \$ 50,00$ ?

Respondi:

- Não sei, enfiaram no meu bolso (ele ri).

E a mãe, já brava:

- Você foi pedir esmola no trem?

- Não pedi! (explica ele rindo).

Angélica também vivenciou situação semelhante em uma doceira.

Escolhia um doce de abóbora quando entrou uma pessoa e perguntou quanto era uma caixa de chocolate. Era $R \$ 8,00$. Na hora que eu estava me retirando a pessoa me deu a caixa de chocolate. Ai eu falei:

- Não, não, obrigada.

E ela:

- Leva sem maldade, eu tenho muita vontade de dar as coisas para os outros. Então, eu pensei: tudo bem, mas é estranho!

Toninho fala sobre as pessoas que têm receio de ajudar a pessoa com deficiência visual: Você fica horas e horas num ponto esperando alguém para te ajudar, ou para atravessar, e as pessoas não vêm porque elas ficam com receio. Ou porque existem cegos que não aceitam a cegueira e não querem ajuda ou porque não sabem nem se dirigir a um deficiente visual.

Fernando relata:

Muitas vezes as pessoas não se anunciam e começam a falar com a gente, a gente leva um susto. Chegam de repente e dizem: - Eu vou te atravessar. E vão puxando. 
Pedro também conta que já foi puxado pela bengala. Da mesma maneira, Sandra, 59 anos, conta que para atravessar uma rua foi ajudada por uma pessoa que, sem querer tocá-la, igualmente a puxou pela ponta da bengala. Nesse dia, sentiu-se como um cachorro abandonado sendo puxado pela rua, o que registrou com tristeza e desalento. Sobre os cidadáos, comenta:

Tem os que passam indiferentes por você, tem os que passam e dizem:

- Nossa, que maravilha, (como se você não estivesse ouvindo, não?) que coisa fantástica, como ela anda direitinho...

E tem aquelas vezes que uma criança vem com a mãe atrás de você e pergunta:

- O que ela está fazendo, porque é que ela está fazendo isso?

E a mãe não responde, não responde... até que a mãe me

ultrapassa, a criança olha para trás e pergunta:

- Por que ela usa aquilo?

E a máe belisca e a criança fala:

- Por que você tá me beliscando?

Tem as relaçôes mais diversas.

Goffman cita publicação da American Foundation for the Blind: ${ }^{2}$

Alguns podem hesitar em tocar ou guiar o cego, enquanto que outros generalizam a deficiência de visão sob a forma de uma gestalt de incapacidade, de tal modo que o indivíduo grita com o cego como se ele fosse surdo ou tenta erguê-lo como se ele fosse aleijado. Aqueles que estáo diante de um cego podem ter uma gama enorme de crenças ligadas ao estereótipo. Por exemplo, podem pensar que estão sujeitos a um tipo único de avaliação, supondo que o indivíduo cego recorre a canais específicos de informação não disponíveis para os outros. (GOFFMAN, 1988, p. 15)

Experiências como essas permeiam muitos dos relatos. Leninha 64 anos, educadora aposentada, teve perda total de visão na juventude. Habituada a caminhar com independência pela cidade, comenta como percebe a reação das pessoas:

2 GOWMAN, A. G. The war blind in American Social Structure. Nova York : AFB, 1957 : 1988. In: GOFFMAN, Erving. Estigma. Notas sobre a manipulação da identidade deteriorada. Rio de Janeiro : Editora Guanabara, 1988 
Eu sinto muito pavor. Não da minha parte. As pessoas que nunca lidaram com deficientes visuais, nunca chegaram perto, só vêem o deficiente visual de longe, quando você se aproxima da pessoa, ou senta num restaurante para esperar o garçom, a gente vê pavor na pessoa que está ali atendendo a gente. Porque não tem a minima noção de como se relacionar com o deficiente visual.

A ignorância sobre a identidade da pessoa cega, diferente, que caminha pela cidade alheia aos outros cidadáos, inspira um folclore de clichês a respeito da deficiência, como a de que cegos teriam audição e olfato superiores aos dos videntes. "Tendemos a inferir uma série de imperfeiçóes a partir da imperfeição original e, ao mesmo tempo, a imputar ao interessado alguns tributos desejáveis, mas não desejados, frequentemente de aspecto sobrenatural, tais como sexto sentido ou percepção." (GOFFMAN, 1988, p. 15).

Sobre o relacionamento de pessoas cegas e videntes, o filósofo Milligan aponta que, pela sua experiência de pessoa que perdeu a visáo muito cedo na infância, apesar de a maior parte dos videntes sentirem-se um pouco nervosos e ao mesmo tempo instigados quando do primeiro encontro com pessoas cegas, tudo isso costuma desaparecer rapidamente com a convivência. Videntes que têm o hábito de conviver com pessoas cegas, muitas vezes se esquecem da deficiência. $O$ autor enumera atividades que podem exemplificar o fato, como: trabalhar, ouvir música, participar de uma mesma reunião, conversar sobre política, economia, história, ciências, situações em que a cegueira pode ser desconsiderada e até parecer irrelevante. Sáo situações em que não há barreiras para o relacionamento. O filósofo inglês acredita que haja uma pequena minoria de videntes que sentem aversão pela cegueira e que resistem fortemente em manter relaçóes com pessoas cegas (MAGEE; MILLIGAN, 1995, p. 50, tradução minha).

\section{Quem é igual e quem é diferente?}

Cegos, gordos, alcoólatras, velhos, hemofílicos, negros, tutelados, aleijados, comunistas, analfabetos, órfẫos, favelados, homossexuais, baixinhos, toxicômanos, feios, presidiários, solitários, gagos, vesgos, neuróticos, desempregados, diabéticos, prostitutas, poetas, impotentes, pobres, gênios. (QUEIROZ,1986, p. 171) 
Se todos aqueles que se desviaram do padrão "normal" fossem autores de uma mesma história, quem sobraria para leitor? Esta é a pergunta feita por Queiroz (1986), coordenador do site Bengala Le$\mathrm{gal}^{3}$. Historiador, vivendo com dois órgãos transplantados, paraplégico como resultado de um acidente de motocicleta, e cego desde os 21 anos como consequência da diabetes, Marco Antonio, casado, pai de um filho, enfrenta em seus percursos inúmeras situaçóes de preconceito. Em seu livro relata situaçóes vividas por ele, e frases que já ouviu:

Eu não sabia que os cegos andavam sozinhos.

Você é o cego mais bonito que já vi (não o homem mais bonito que já vi)

(QUEIROZ, 1986, p. 105)

A diferença significativa gera estranhamento e, nesse sentido, temos o conto de Wells (1954), sobre uma comunidade de cegos que desconheciam videntes. O autor relata como Nunes, o protagonista vidente, cai de uma montanha e é encontrado pelos moradores cegos. Estes, ao se depararem com uma pessoa diferente, resolvem levá-la aos mais velhos. Tropeçando na escuridão do caminho, é logo rotulado como uma pessoa que não tem ainda os seus sentidos desenvolvidos, pois não sabe caminhar com agilidade e desenvoltura. Depois de um tempo vivendo entre eles e, sem conseguir se adaptar, Nunes decide deixar a comunidade. A outra alternativa, encontrada pelos moradores cegos para a sua adaptação, seria extrair-lhe os olhos, pois estes atrapalhavam. Naturalmente, sem enxergar ele deixaria de ser diferente.

\section{É muito mais fácil ser cego do que ser visto como cego ${ }^{4}$.}

Esta colocação de Queiroz é tema de comentários de outras pessoas com deficiência visual, que no cotidiano profissional ou social, se ressentem do estranhamento da população. Paulo, psicólogo, 44 anos, relata as suas vivências e interaçóes sociais:

Nos primeiros encontros com as pessoas nas ruas, as primeiras conversas giram em torno da cegueira. Há uma curiosidade natural. A primeira pergunta é: você é cego total ou

\footnotetext{
3 http://bengalalegal.com/

4 Declaração de Queiroz ao jornal Estado de Minas, em 19/09/2005.

Disponível em www.bengalalegal.com/estado-de-minas - Declaração de amor à vida.
} 


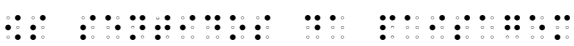

enxerga alguma coisa? Isso dá até pra fazer estatística, todo mundo pergunta. Você perdeu a visão quando? Você nasceu assim ou ficou cego? Atitude desencanada, bom humor, não é muito fácil em todas as situaçóes, a não ser que você já tenha tanta vivência dentro da cegueira quando então as perguntas já não abalam mais. Mas, para uma pessoa que recém perdeu a visão, lidar com essa nova situação é um desafio, é enfrentar novas situaçóes. Passei 25 anos sem ninguém me perguntar se eu enxergava ou não enxergava. Encontrava as pessoas, as reconhecia, e ai de repente eu tenho que lidar com esses universos humanos, essas realidades muito complexas. Muita gente pergunta esse tipo de coisa e eu vejo que não é por maldade ou perversidade, é um interesse espontâneo, natural, ela não está habituada, nunca conversou com um cego, então ela quer saber como é, o que sente... Quando eu digo que perdi a visão, algumas pessoas gostam de ver a metade cheia do copo: - ah, então é bom porque você conhece as formas das coisas, tem referências, você lembra. Outras pessoas vêem a metade vazia, dizem: - puxa, pior, quem nunca enxergou pelo menos não sente falta. As duas coisas são verdades, as pessoas sáo muito diferentes e eu vivo tentando sentir cada pessoa como única, não como um padrão de pessoas que discriminam, todas as pessoas discriminam, até às vezes aparecem aquelas senhoras com voz piedosa, que é o que mais me desagrada, senhoras com aspecto religioso, carola, fazendo uma boa ação, tristes. Mas estou aprendendo a ver que essas pessoas já carregam uma postura de piedade sem realismo, postura própria.

Posturas como as encontradas por Paulo acabam por coagir pessoas com deficiência a ponto de inibirem os seus percursos pela cidade. Qual é o benefício de se expor e qual é o preço dessa exposição?

Veiga $^{5}$, em obra autobiográfica informa que a pena da cegueira está menos na carência da visão do que nas suas consequências, fruto da incompreensão por parte do vidente. $\mathrm{O}$ rapaz jovem e tímido que foi, tinha poucos amigos e frequentava apenas a casa de um deles, aquele que o tratava como igual. Durante as visitas, a chegada de um terceiro companheiro, relata, punha fim à tranquilidade e colocava-o de plantáo, tenso, para as perguntas inevitáveis que surgiam à hora do lanche: "Ele come sozinho?" Quando o bolo era muito macio, por mais que facilitasse o fato de já recebê-lo cortado, gesto gentil do amigo e dono da casa, fazê-lo parar sobre o garfo era tarefa para videntes, complicada e constrangedora. "Quando sentia na boca o garfo 
vazio, era como uma descarga me houvesse fulminado. Não conseguia captar amizades, apenas simpatias piedosas", relata o autor.

"Os homens não nascem iguais nem desiguais, são, de cada vez, inseridos nas redes que tecem esta ou aquela normalidade" ${ }^{6}$. Este mesmo texto aponta ainda, sobre normalidade adaptativa, a visão de Cooper, Laing e Burke, para quem a normalidade social é uma questão de aprendizagem, e questiona: "quem são os homens normais"? Em exclusão/integração temos que nesse processo cada parte se identifica com a sua natureza, dividindo-se na que exclui e na que é excluída.

GOFFMAN7 expóe que a sociedade entende o indivíduo como "intérprete de múltiplos papeis, não como uma pessoa com determinado papel [...], mas como uma pessoa de muitas identificaçóes". No entanto, em relação à pessoa com deficiência visual, a sociedade tende a perceber, antes de qualquer coisa, a falta, criando assim uma identificação para aquela pessoa não pelos seus atributos, mas pelo que o torna diferente. É comum pessoas usarem expressóes como "aquele cego" ou, pior ainda, "aquele ceguinho", no lugar de "aquele massagista” ou "aquele professor", ou, "o psicólogo".

A maneira como o cidadão que enxerga convive com o cidadão que tem deficiência visual tem alguns pontos em comum com o estudo desenvolvido por Norbert Elias e John Scotson ${ }^{8}$ em uma pequena comunidade inglesa, no final dos anos 50. Podemos simular aqui que pessoas sem deficiência (aparente) seriam os "estabelecidos" e as pessoas cegas os "outsiders". O cidadão sem deficiência é dono de poder, de prestígio, com a expectativa da ascensão social e profissional; apropria-se da cidade e nela tem acesso a todo e qualquer lugar: este seria o "estabelecido".

Ao cidadão com deficiência visual é reservado o papel de "outsider": ele tem acesso apenas a determinados locais e depende para isso que lhe seja concedida permissão de frequência, que vem na figura da acessibilidade. Com raras exceçóes, exerce profissóes que lhe são possíveis e indicadas; muitas vezes são formados pelos cursos oferecidos pelas próprias instituições de deficiência visual, pelo que a sociedade entende que ele seja capaz, devido à sua limitação: massagista, telefonista, operador de telemarketing. Não deve aspirar por prestígio ou ascensão social. Não é comum ser um adquirente em

6 DESCAMPS, C. Normal lanormal.In: Enciclopédia EINAUDI. Exclusão /integração. Edição Portuguesa: Imprensa Nacional - Casa da Moeda, vol. 23, 1994

7 GOFFMAN, E. Encounters - two studies in the sociology of interaction. Bobbs-Merril, 1961.

8 ELIAS, Norbert. Os estabelecidos e os outsiders. Rio de Janeiro : Zahar, 2000. A pesquisa, sobre a sociologia das relaçóes de poder, descreve a diferença e desigualdade social como relaçóes entre estabelecidos e outsiders. Winston Parva, nome fictício do povoado industrial inglês, tinha uma comunidade relativamente homogênea. Era formado por um bairro relativamente antigo e ao redor duas povoaçóes formadas em época mais recente. A única diferença entre elas era exatamente esta, um grupo de antigos residentes, e outro de recém-chegados. O estudo foi desenvolvido no final dos anos 50 e foi o trabalho mais importante realizado por Elias durante 40 anos, durante os quais pouco publicou. 
potencial de bens destinados ao poder aquisitivo, como carros, jantares em restaurantes elegantes, itens pessoais sofisticados, signos de ascensão social.

Segundo Elias, a maioria das pessoas usa uma série de expressóes que estigmatizam outros grupos e que só fazem sentido no contexto de relaçóes específicas entre estabelecidos e outsiders. O autor dá alguns exemplos: "crioulo", "carcamano", "sapatão", "gringo" (ELIAS, 2000, p. 27) aos que eu acrescento "ceguinho".

Quando sai às compras, Toninho vivencia as experiências de um "outsider":

Vou a uma loja fazer compras e as pessoas acham que estou pedindo esmola. Uma vez eu fui comprar um armário no centro de São Miguel, a moça falou para o colega:

- O ceguinho veio buscar o dele...

Eu falei:

- Não, eu não vim buscar nada, eu vim comprar, eu até mostrei tudo, eu trabalho.

Numa cidade como Sáo Paulo ainda existe isso das pessoas acharem que

o deficiente visual não trabalha, só vive de benefício do governo.

Uma vez fui abrir uma conta em um banco, e a moça perguntou:

- Você tem renda? Tem o comprovante do benefício?

Eu respondi:

- Não, minha querida, não ganho benefício, eu trabalho, sou assistente social da prefeitura. Ela ficou admirada:

- Nossa, como pode? Você não enxerga, como você trabalha?

Respondi que fui habilitado para isso. Fiz orientação e mobilidade, fiz

faculdade, não foi fácil, prestei concurso para a prefeitura. Então, existe esse problema das pessoas acharem que não temos capacidade.

Neste sentido, Queiroz aponta que na vida profissional, pessoas com deficiência dificilmente perdem o estigma, mesmo sendo competentes e que é mais fácil dar esmola a uma pessoa cega do que acreditar na sua capacidade de trabalho.

[...] passei dois anos e oito meses estagiando. O pessoal do trabalho já brincava comigo que eu era Estagiário Consultor, Sênior, ou coisa do gênero. Nunca soube ao certo que tipo de discriminação estava sofrendo, mas alguma realmente havia, visto que vários colegas foram promovidos, inclusive estagiários com menos experiência do que eu. (QUEIROZ, 1986, p. 121) 
Hélio, operário aposentado da indústria automotiva, relata como conseguiu trabalho por intermédio do SENAI de São Paulo que, nos anos 60, tinha um setor especializado para atender pessoas cegas:

Eles pesquisavam nas indústrias os trabalhos que os cegos poderiam fazer e encaminhavam os inscritos lá mesmo no SENAI para as fábricas que ofereciam vagas.

Já dentro da fábrica, não se considerava o afeto do operário para com a atividade, ou a empatia que ele pudesse ter para com determinado setor. Ele simplesmente era designado para uma função que, segundo os próprios operários, nunca era de comando, mas sempre de obediência. Hélio relata:

Chegava na fábrica e o encarregado mostrava o serviço. E dai a gente aceitava e ficava com aquele mesmo; tenho conhecidos que passaram mais de 30 anos fazendo a mesma coisa. Eu trabalhava no setor da embalagem de peças que iam para as concessionárias. Embalava peças pequenas em caixas ou sacos plásticos. Nas caixas iam muitas peças, dependia do tamanho delas, mas havia peças que eram embaladas individualmente, uma em cada caixa. O trabalho era exaustivo principalmente o de embalagem das peças pequenas, quando 120 ou 140 eram embaladas na mesma caixa. Muitas vezes chegava um carrinho com 80 mil peças. Conhecia o carrinho cheio pelo som que ele fazia. Pegava as peças para colocar na caixa de 4 em 4 e fazia duas caixas ao mesmo tempo, com as duas mãos ao mesmo tempo. Tinha que ter atenção máxima para não confundir o número de peças embaladas. Antigamente o trabalho era feito sentado, mas as pessoas ficavam com sono, devido às más condiçôes do local, muito quente, com telhado de telhas de Eternit. Principalmente depois do almoço acabavam cochilando. A partir de quando eu comecei já se trabalhava de pé. Mesmo assim cheguei a dormir encostado na mesa, mesmo de pé. O trabalho era estafante e o regime era de escravidão. Sentávamos apenas para comer.

Hélio relata que na fábrica, quando não havia trabalho, os operários eram obrigados a reembalar as peças, inutilmente - um trabalho frustrante, humilhante. Tirar as peças da embalagem e recolocá-las em nova embalagem, sendo que a anterior ainda estava intacta. Hoje, relembrando, percebe o absurdo da tarefa, feita apenas para não deixar que os funcionários parassem. $\mathrm{Na}$ época, jovens, não se davam conta da gravidade do fato. 
Sandra relembra a sua vida de estudante, a batalha para conseguir o seu primeiro emprego, em 1980, e as dificuldades superadas para conseguir provar sua eficiência profissional:

Na época, eu cursava o clássico, que me levaria a seguir a área de humanas, imaginava fazer filosofia pura na USP. Prestei vestibular já com outras opçóes também, história ou serviço social. Após passar pela primeira fase do vestibular, fui entrevistada por jornais que me questionavam o que iria fazer depois de formada. Era pouco comum o cego cursar faculdade. Não fui aprovada na USP, mas sim na Faculdade Paulista de Serviço Social, SP, unidade essa agregada à PUC/SP. Durante o curso, já no final do primeiro ano, fui fazer estágio no DAIS, órgáo da Secretaria do Bem-Estar Social. Consegui o mesmo juntamente com uma colega de curso através do CIEE e recebiamos uma bolsa de meio salário minimo. No terceiro ano, fui fazer estágio em uma empresa de aparelhos eletrônicos que ficava na vila Olimpia e logo mudou para Socorro. Caminhava desde a Praça da Sé até a Praça das Bandeiras para tomar um ônibus que fosse para Socorro. Foi uma época em que a cidade era perfeitamente utilizada por estudantes, pessoas de meia idade, sem medo, pois não havia batedores de carteira, assaltantes etc. Isso se deu de 1971-1974. No último ano da faculdade, o quarto, fiz estágio num Centro de Reabilitação do INPS, Ipiranga. Depois de formada, a batalha foi grande, havia anúncios de emprego para Assistentes Sociais, mas quando eu chegava no local havia tantas candidatas que logo me entrevistavam e diziam que a profissional para o cargo precisava enxergar. Era comum ir aos locais anunciados em jornal ou indicados por alguém e ao chegar ser logo entrevistada e dispensada, pois afirmavam que a vaga era pra quem enxergasse. Devido à inexperiência ou mesmo à intransigência dos entrevistadores, não havia diálogo. Até uma assistente social questionada pela minha mãe, sobre uma possibilidade de trabalho para mim, disse que não esperasse isso, que ninguém iria me empregar. Prestei então um concurso público federal. Estudei para ele com uma colega de faculdade que lia a matéria pedida no edital em voz alta e assim eu e ela fomos aprovadas com a mesmissima nota. Minha prova para esse concurso foi extremamente fiscalizada; foi gravada, respostas escritas em braille e ditadas para um fiscal e assinada por duas testemunhas que presenciaram a abertura da mesma. Quando fui chamada para assumir, encontrei barreiras por parte do oftalmologista que devia fazer o exame de admissáo, ele náo sabia o que fazer comigo. 
Fui chamada em 1980 e fui várias vezes ao oftalmologista que deveria dar o laudo de admissão; ele náo queria, pois afirmava que náo sabia como poderia exercer minhas atividades sem enxergar. Juntei então vários recortes de jornal que explicavam quais os procedimentos legais dos deficientes para realizarem concurso e, se aprovados e rejeitados, os amparos legais. Cabe dizer aqui que um sócio advogado da Associação de Deficientes Visuais e Amigos ADEVA me proporcionou todo apoio. Diante disso, a funcionária do departamento de pessoal me afirmou que era uma questão de tempo, pois eu poderia, se negada minha admissão, entrar com processo administrativo. Quando assim conversávamos a funcionária chamou um médico que passava pelo corredor, expôs o caso e o mesmo assinou o laudo imediatamente dizendo que trabalhava no Hospital Nossa Senhora de Lourdes com uma médica cega e então por que eu não poderia atuar como assistente social? Até eu fiquei surpresa, pois não havia ouvido falar de médicos cegos clinicando. Assim, iniciei minhas atividades como profissional no "Instituto Nacional de Assistência Médica da Previdência Social - INAMPS". Fui lotada no PAM - Posto de Assistência Médica Várzea do Carmo, no bairro do Glicério. Para exercer minhas atividades tive que criar meus meios, a máquina de datilografia foi meu grande instrumento. Atuei como as outras colegas, sem facilidades tecnológicas, mas com colaboração de algumas outras assistentes sociais. Em 1989, fui designada para assumir a chefia do setor com 15 assistentes sociais. Para relatórios mensais e anuais utilizava o braille e posteriormente datilografava-os. Meu trabalho foi sempre respeitado pela chefia de SS e do Posto de assistência médica onde trabalhei. Procurei sempre me colocar como uma profissional igual às outras e quando me faltou recurso humano, uma secretária que permanecesse no setor, fui reivindicá-la; acredito que essa e outras posturas me levaram a chefiar o setor por dois anos.

Sandra é uma exceção. Ela mesma, em outro momento do depoimento coloca:

Com certeza, ainda existem muitas pessoas que julgam o deficiente visual apenas mais um. Cabe ao mesmo mostrar sua competência, não se acomodar ao salário e brigar pelo que quer. Isso é preciso que venha de dentro para fora, não apenas falando, empunhando bandeira, mas agindo, levantando da cadeira e saindo para o desafio. Hoje em dia, no âmbito do trabalho o deficiente visual tem maiores oportunidades; desde o início da informática no Brasil se saíram muito bem. Criaram seus mecanismos, aperfeiçoaram os mesmos e até hoje é um campo muito preenchido por deficientes visuais. 
Não se pode falar de trabalho para deficientes sem citar a "lei de cotas" que existe há anos, mas que atualmente o Ministério Público do Trabalho vem cobrando a sua eficácia. Acredito ser um tema discutivel; leva os deficientes para os locais de trabalho, mas o que se constata é que os encosta para cumprir a lei mas não os capacita. O deficiente por sua vez se acomoda, pois está recebendo salário e todos os outros beneficios. Existem, é claro, exceçóes, de ambos os lados. Mas são raras. A consciência dos empresários deixa a desejar e os deficientes por sua vez, sentem-se acuados. É preciso criar seus meios de trabalho, ir buscar e mostrar que pode fazer, assim é possivel que os outros acordem. Julgo que essa lei seria um grande avanço se aplicada de acordo, se pessoas deficientes mais aptas para aquelas atividades fossem contratadas com o mesmo rigor que é contratado o não deficiente. $O$ vale transporte para deficientes foi a meu ver, uma conquista social. Pessoas com deficiências graves têm sua mobilidade bastante favorecida num transporte coletivo. É avanço social no que diz respeito também aos idosos, é produto de sociedade civilizada. Quanto ao que se esperava do deficiente na época de 68, acredito que nada além dos trabalhos em linha de produção em induistrias, principalmente automobilísticas. Eles eram tidos como exemplo de superação de barreiras e citados como referência. Quanto a outras profissóes, talvez houvesse, mas eram esporádicos e desconhecidos.

Queiroz também relata sua trajetória profissional:

[...] O mercado de trabalho para professores de história era péssimo. Cego, então, ainda mais. Além disso, não tinha o grande ideal de ser um historiador. [...] Quando era pequeno, queria ser mecânico ou desenhista industrial [...] depois disso quis ser arquiteto. [...] Depois que cheguei à adolescência, [...] ainda quis ser médico [...]. Procurei o (Instituto) Benjamin Constant novamente, visto que havia me afastado um pouco de lá. Queria saber o que um cego poderia fazer, além de ser professor. Estavam em voga dois cursos profissionais: revelação de raios X em câmera escura e programação de computadores. (QUEIROZ 1986, p. 117-118)

Conta que o computador era estranho para ele, tinha preconceito contra as pessoas "frias e calculistas” que trabalhavam na área técnica. Para fazer o curso seria necessário conhecer braille, para etiquetar 
discos, fitas, escrever endereços. Ia demorar um tempo, refletiu. No entanto, relata, vivia de uma pensão deixada pelo pai, pelo fato de ser "inválido", e a pensão estava sendo corroída pela inflação. Para evitar depender da mãe, também pensionista, e se capacitar para um salário atrativo como o de programador, apesar de não ser uma das suas preferências, resolveu iniciar o curso de braille, que o capacitaria a fazer o curso de programação de computadores. Queria estar capacitado para exercer a função com eficiência, sabia que podia ser um dos melhores alunos. Reflete sobre a complexidade do campo de trabalho para cegos:

Em geral, quando um cego faz uma besteira numa empresa, culpam a cegueira e não o profissional. Desde que a cegueira pertence a todos os cegos, começa a ficar ruço a entrada de outros naquela empresa, fechando-se o mercado. (QUEIROZ, 1986, p. 120)

Sandra faz um relato sobre o mercado de trabalho e o início do envolvimento de profissionais com deficiência visual na programação de computadores:

Em 1971, em São Paulo, dois deficientes visuais deram início ao trabalho com programação com informática. Tiveram um bom resultado, foram empregados em posteriormente, em 1973, iniciaram cursos para outros deficientes visuais. Hoje é uma das áreas onde mais se emprega deficiente visual; durante esses anos surgiu também o serviço de telemarketing, que, graças ao dominio do uso de computadores, o deficiente visual é bem sucedido. Outros profissionais surgiram, como assistentes sociais, psicólogos, advogados, pedagogos, professores em geral. Acredito que nesse periodo de 40 anos houve um crescente aumento de profissionais que jamais se encontrou na história, pelo menos do Brasil. A oferta de trabalho durante todos esses anos não foi grande, porém as pessoas se colocavam através de concursos. Hoje a oferta de espaços para trabalho para o deficiente visual é muito maior, mesmo sem contar a Lei de Cotas que obriga as empresas a terem percentual de deficientes empregados, relativo ao número de funcionários.

Quanto ao preconceito, acho que ele sempre existirá com deficientes, quando se trata de pessoas diferentes que precisam de qualquer tipo de ajuda.

A observação de Sandra sobre o preconceito no exercício da profissão expóe uma situação que perdura até hoje, mesmo que de maneira velada. Nos anúncios classificados do caderno de empregos dos jornais, enquanto pessoas sem deficiência aparente são procuradas pelos seus talentos, pessoas com 
Os sentidos da paisagem

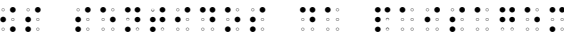

deficiência declarada são procuradas exatamente pelo que lhes falta. Segundo o IBGE, há no Brasil mais de 35 milhóes de pessoas com deficiência visual (18,8 por cento da populaçáo). A grande maioria não está inserida no mercado formal de trabalho. Nas ruas, muitas das pessoas cegas são vendedores ambulantes. A maior parte não teve acesso à educação.

\section{empregos Aviso aos anunciantes \\ "De acordo com 0 art. $5^{\circ}$ da CF/88 cle art. 373-A da CLT, não é permittido anuíncio de emprezo no qual haja referência quanto ao sexo, idade, cor, situaç̧̄o familiar, ou qualquer palavra que possa ser interpretada como fator discriminatório, salvo quando a natureza da atividade, pública e notoriamente, assim o exigir:"}

Vagas para engenheiro, decorador, dentista... deficientes; polidor... portadores de deficiência, portadores de necessidades especiais... produtor, professor, promotor.

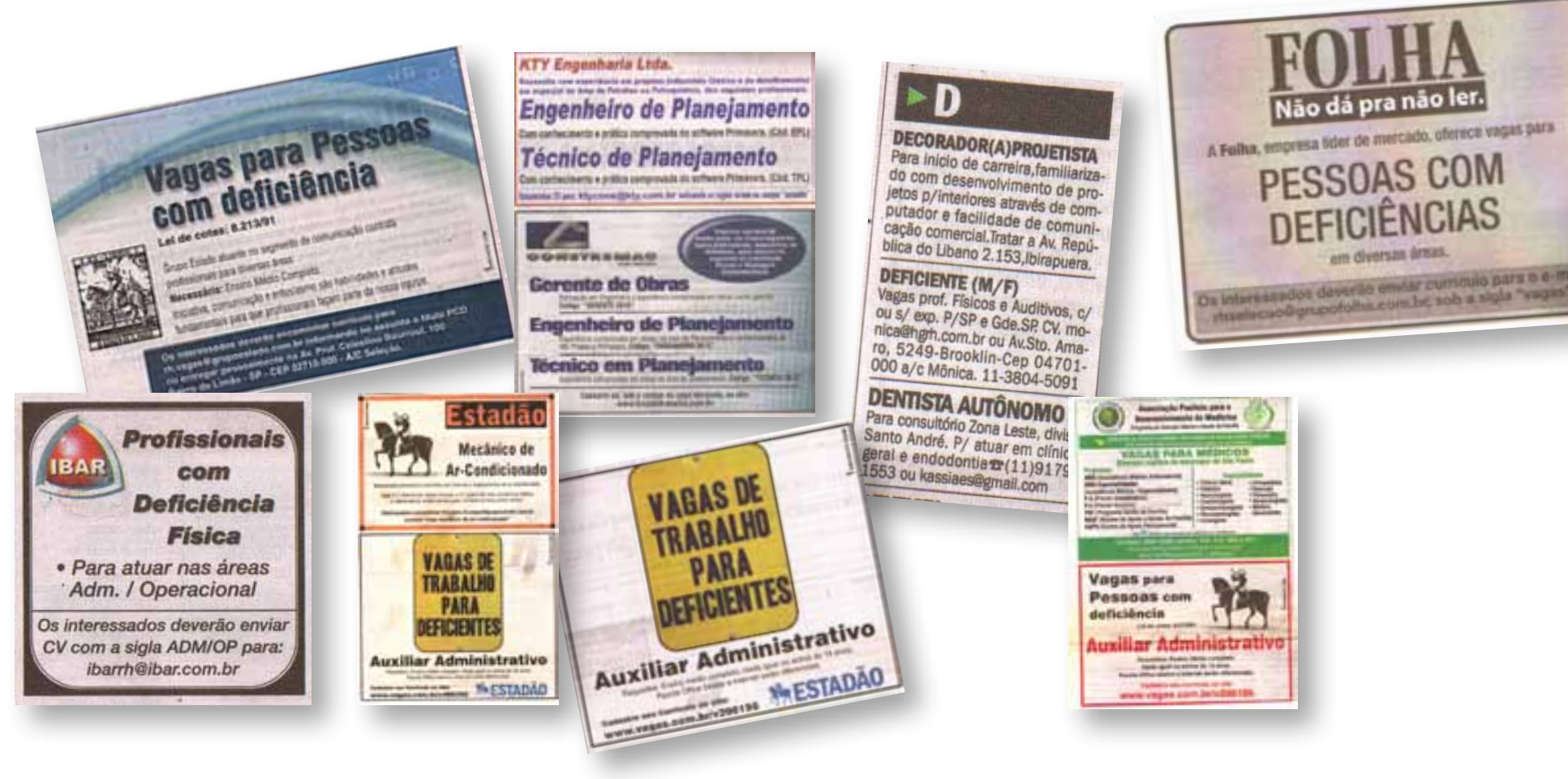


Empresas buscam profissionais com deficiências para atender à Lei de Cotas 8.213/91 e fugir das duras multas impostas pela Delegacia Regional do Trabalho?. Ressentem-se da falta de profissionais qualificados e para abreviar a situação, cumprindo com as imposiçóes da Lei, muitas vezes contratam pessoas com deficiência que não exercem a função para a qual foram contratadas e são vistas apenas ao receber o salário. Deixamos uma época em que nem as próprias famílias acreditavam no potencial produtivo de pessoas com deficiência, mas não conquistamos ainda uma mentalidade aberta para a convivência com o diferente, que está fora do padrão imposto pela sociedade, o que não é "normal".

Goffman ${ }^{10}$ cita o relato de Henrich e Kriegel sobre uma pessoa com esclerose múltipla e sua reflexão sobre normal e anormal:

Tanto as mentes quanto os corpos saudáveis podem estar aleijados. O fato de que pessoas normais possam andar, ver e ouvir não significa que elas estejam realmente vendo e ouvindo. Elas podem estar completamente cegas para as coisas que estragam a sua felicidade, totalmente surdas aos apelos de bondade de outras pessoas; quando penso nelas não me sinto mais aleijado ou incapacitado do que elas. Talvez, num certo sentido, eu possa ser um meio de abrir os seus olhos para as belezas que estão à nossa volta: coisas como um aperto de mão afetuoso, uma voz que está ansiosa por conforto, uma brisa de primavera, certa música, uma saudação amistosa. Essas pessoas são importantes para mim e eu gosto de sentir que eu posso ajudá-las. (GOFFMAN, 1988, p. 21)

Segundo Sekkel e Casco"11 "A busca da própria felicidade e a indiferença diante do sofrimento alheio são marcas importantes na sociedade atual". Citam Adorno, ao refletirem que existe uma frieza dentro de nós, sem a qual não conseguiríamos viver nos dias de hoje e que as pessoas com propensão ao

9 Criada para diminuir a exclusão e o preconceito contra as pessoa com necessidades especiais, a Lei de Cotas completou 20 anos em 24 de julho de 2011. Mas, apesar do tempo, muitas empresas ainda não se adaptaram à legislação. O Ministério Público do Trabalho do Estado de São Paulo (MPT-SP) registra alta de 83,3\% nas denúncias dessa natureza, numa comparação entre 2010 e os primeiros seis meses de 2011. No ano passado, 138 procedimentos foram instaurados pelo MPT-SP. Só em 2011 foram 253 denúncias que resultaram em inquérito civil, incluindo reclamaçóes contra firmas que não cumprem a cota. A maior parte, 157 denúncias, está concentrada na capital, na Baixada Santista e na Grande São Paulo. Fonte: jornal O Estado de São Paulo, Número de denúncias cresce 83\% em um ano. p. 2. Caderno Empregos, 03/07/2011

10 HENRICH, E. \& KRIEGEL, L. Experiments in Survival. Nova York : Association for the Aid of Crippled Children, 1961, p. 35. In GOFFMAN (1988, p. 21)

11 SEKKEL, Marie Claire et al. Educação inclusiva: percursos na educação infantil. São Paulo : Casa do Psicólogo, 2008 p. $19-20$ 
$\because \because \quad \because \because \because \because \because \because \because \because \because \quad \because \because \quad \because \because \because \because \because \because \because \because$

preconceito sentem muita dificuldade em se relacionar com o não-idêntico, com quem não se identificam. A defesa contra a ameaça é o preconceito.

Toninho é um observador crítico do pensamento coisificado e do apreço à estereotipia:

Em restaurante eu gosto de frequentar lugares conhecidos, mas também lugares

desconhecidos, para eu poder observar como é o tratamento ao deficiente visual.

Você chega num local, as pessoas não sabem nem como te servir. Acham que

você vai pedir. Outro dia na Vila Mariana a moça falou para a outra:

- Ele veio pedir esmola.

E eu respondi:

- Não querida, eu vim tomar um café, mas agora não tomo mais café

aqui nessa lanchonete, nem de graça eu quero. Você não pode julgar uma

pessoa, será que você nunca viu um deficiente visual na sua vida?

E quando eu estou meio nervoso eu falo:

- Nunca viu um CEGO na sua vida?

Porque é desse modo que eles tratam a gente mesmo: ceguinho.

Chevigny $^{12}$, em livro autobiográfico, reflete sobre as mudanças na vida da pessoa que perde a visão:

Pena é o nome da emoção que endereçamos às tragédias. Aristóteles tinha muito a dizer sobre o efeito de limpeza da pena no homem que a sente, mas pouco considerou o seu efeito no homem que precisa enfrentar uma vida com ele. Ele tem que aceitá-lo ou rejeitá-lo, não há campo intermediário. [...] Manter a identidade própria não é mais possível. [...] Suas açóes outrora mais ordinárias como caminhar indiferentemente pela rua, colocar ervilhas no prato, acender o cigarro, deixam de ser comuns. Ele se torna uma pessoa diferente, incomum. Se ele é hábil e mostra segurança nos seus atos, suscita o mesmo tipo de admiração inspirada nos mágicos que tiram coelhos das cartolas. Se ele insiste em ir além das açóes comuns, como lavar louças, preparar coquetéis ou pendurar suas próprias roupas, ele é olhado como um ser extraordinário. E se faz isso com disposição, é sensacional. (CHEVIGNY, 1962, p. 140, tradução minha) 
Nas atividades básicas do cotidiano, podem ocorrer conflitos quando pessoas com deficiência visual são expostas às situaçóes de dependência, ajuda, sujeição e compreensão de outras pessoas. Angélica, que depende de ajuda para fazer compras, sente falta da estrutura com a qual contava antes de se mudar:

Morei lá dois anos e meio, achava mais fácil do que aqui. Lá já consegui ir no mercado, me virava melhor que aqui. Aqui o problema maior é o meu bairro porque não tem calçada direito. A fundação distribuiu uma vez um livro de dicas culinárias e eu aproveitei bem. Eu também ia no mercado por causa do xampu e condicionador que eu gostava, um grandão, $450 \mathrm{ml}$, qualidade boa, preço também, chegava no mercado não esperava nem um minuto, vinha of funcionário.

Angélica relata uma situação de conflito ocorrida no local onde atualmente faz suas compras:

Um dia, uma funcionária que estava me atendendo falou:

- Chama alguém pra vir com você.

Eu disse que não tinha ninguém, e ela respondeu:

- Tem que ter!

Respondi a ela:

- Amiga, se você vai falar assim, tenho que falar com o gerente.

Dai chegou na hora do xampu ela falou que não tinha. Eu comentei:

- Desculpa, mas você nem procurou.

Ela ficou querendo que eu levasse outro, dizia:

- Eu se fosse você levava esse.

Eu falei que não, que eu ia levar o que eu queria.

Fernando, que participa da mesma entrevista, logo completa:

Eu falaria que eu sou consumidor, eu pago o imposto, o que eu estou pagando é parte do seu salário, então eu vou levar o produto que eu quero. Se você náo quiser me fornecer, vou falar com o gerente. Se você chama o gerente ela só falta beijar você. 
Leninha, dona de casa, vai com frequência às compras e tem facilidade e independência nos percursos. Aborrece-se, no entanto, com os vendedores ambulantes que, além de constituírem obstáculos nas calçadas, muitas vezes não são corretos nas informaçóes, provocando situaçóes de conflito, como relata:

Eu sou aposentada, mas saio muito, sou dona de casa, vou à padaria, açougue, mercado, ao banco, corro o bairro. Sou conhecida por todos, donos das lojas, dependendo da loja entro, tomo um cafezinho, passo a mão nas roupas, vejo se me interessa. Outro dia, eu estava saindo do banco com chuva, atravessei a rua e, como estava chovendo muito, resolvi pegar o ônibus uns quatro quarteirôes para ir para a minha casa e bem em frente ao ponto do ônibus tem banquinhas de camelô. Precisava de um guarda-chuva para o meu filho. Ela só tinha aqueles grandóes, não tinha do pequenininho. Ela falou: - Serve pra gente andar em dois, cobre bem, leva esse aqui.

E já foi empurrando. Ai eu disse para ela esperar, não ir empurrando, que eu queria saber a cor, não era para mim, era para o meu filho.

- É preto.

- E tem de outra cor?

- Tem outro aqui que é estampado.

Peguei o dinheiro da carteira, paguei, e me lembrei de perguntar se tinha outro modelo de cabo, o reto.

- Além desse cabo a senhora não tem o outro, com cabo reto?

E ela respondeu:

- Ah, não tem não, e olha lá, o seu ônibus vem vindo.

Perdi a paciência e disse:

- Sua malcriada, qual é o problema, eu posso perder o ônibus, eu quero é levar o guarda-chuva que me interessa! Como eu já tinha pago mesmo, ela queria que eu fosse embora, não era para levar o que eu queria, era o que ela determinou. 


\section{O ser humano é bem complicado ${ }^{13}$}

Toninho se sente mais seguro ao chegar a seu bairro, na vizinhança da sua casa. Está em local familiar, onde conhece e é conhecido, onde confia na ajuda das crianças.

No meu bairro o pessoal é amigo, todo mundo me conhece. Às vezes não sabem o nome. Mas se você chegar e falar que quer ir na casa de um deficiente visual assim, baixinho, vão falar que não sabem o nome mas sabem onde mora. Às vezes, não ajudam para atravessar a rua, o ser humano é bem complicado, tem alguns que ajudam, mas tem alguns que acham porque eu tenho deficiência visual vêm com umas brincadeiras absurdas. Por exemplo, um cidadão que mora em frente a minha casa; todo mundo sabe que eu estando na minha rua sei como achar o meu portäo. Só que três vezes ele já fez essa brincadeira, na terceira quase quebro a bengala na cabeça dele. Ele foi me ajudar, sem necessidade, pois eu já estava na minha rua. Se eu estiver na calçada fica mais fácil achar o portão de casa, pois eu já conheço todos os meandros da minha calçada. Ela é diferenciada, tem um degrau um pouquinho mais alto, uma referência a mais para eu saber. Ele foi pelo meio da rua. Ai ele foi passando o portão de casa. Ai a minha mãe falou:

- Seu Antonio, o senhor tá passando com ele.

E foi três vezes. Na primeira eu aceitei, a segunda, na terceira eu falei:

- Pô, você tá achando que eu sou bobo?

- Ah, eu quero saber se você conhece o caminho.

Você encontra esse tipo de coisa, a pessoa querer fazer gracinha. Mas você sabe que as crianças são muito mais prestativas e solidárias que muitos adultos. As crianças, quando eu chego, se está chovendo, garoando, elas já vêm me ajudar. Não fazem esse tipo de brincadeira. Jamais.

Se a caminhada dos pedestres, a arte de moldar percursos (CERTEAU, 1994, p. 179), puder ser comparada à arte de moldar frases, podemos dizer que os trajetos das pessoas cegas narram histórias de suspense, compensadas pelas poucas relaçóes sociais bem sucedidas. Alcides, aposentado, relata as suas incursões pelo centro de São Paulo.

13 Observação de Toninho 


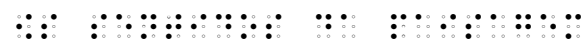

Chegando no ponto de ônibus às vezes a pessoa oferece ajuda, às vezes preciso pedir. Lá no meu bairro náo, porque a maioria me conhece e para. Lá é mais tranquilo. Os motoristas já me conhecem. Os motoristas são uma "maravilha" (ironiza). Eles vêem o cego no ponto sozinho e passam direto. Há alguns que às vezes param e perguntam: - Ô amigão, vai pra onde, este é o tal ônibus, serve pra você? Não? Ah, tudo bem... Mas isso é exceção. A maior parte passa direto. Para ilustrar isso, eu ouvi uma conversa de um motorista com outro colega: "É, ele pega várias vezes o ônibus comigo. Mas outro dia eu fiquei olhando, olhando, ele não fez sinal eu fui embora."

Ele conhece o sujeito, sabe que ia pegar o ônibus com ele, e só porque não fez sinal, não parou. É proposital.

Vou a uma loja, muitas vezes encontro a calçada, mas tenho que perguntar ao transeunte qual é a loja. Numa determinada época eu usava bengala de aluminio, e como o metal é duro, entortavam, e quando ia desentortar, quebrava. E o pessoal na rua não olha nada, é pisão daqui, chutão dali, quebram mesmo, nem vêem a bengala, parece gado, entortam.

Malu, 52 anos, técnica em radiologia, confirma:

Tem muita gente que anda alheia, olhando para as lojas, tropeça na bengala, capaz até de me derrubar se eu não estiver firme no chão, às vezes derrubam a bengala e nem apanham.

Deixar a segurança da casa nessas condiçóes demanda coragem e determinação. Os trajetos exigem que pessoas com deficiência visual se mantenham vigilantes, atentas à direção, aos vazios, aos detritos, buracos, à memória que têm do lugar, às barreiras e obstáculos. São provas desafiantes que distinguem pessoas dispostas à exposição e ao risco, de outras pessoas retraídas, que acabam por se excluir do convívio que a cidade propicia.

$\mathrm{O}$ estudo The making blind man, de Robert A. Scott ${ }^{14}$, comentado pela Rede Saci, aponta que a cegueira é uma condição estigmatizante. "A identidade social de um homem e, na verdade, sua personalidade total, é espoliada quando ele se torna cego". Ele passa a depender de ajuda e de

14 Os artífices de cegos. Extraído do estudo de Robert A. Scott. The making blind man - a study of adult socialization. Princeton University. Russel Sage Foundation. New York. Editado em 11/01/2002 em www.saci.org.br 
condiçóes especiais para se sentir incluído e se locomover com independência pela cidade. Fica evidente que todos os preceitos normativos da acessibilidade não são suficientes para a inclusão, e nem oferecem condição para contemplar os conflitos do sentimento, da emoção, da memória e da afetividade do lugar.

$\mathrm{Na}$ maior parte das vezes, as leis de acessibilidade são descumpridas e ignoradas e o fato de não se considerar os fatores emocionais, da percepçáo, da interpretaçáo do lugar, traduz-se em observar a inclusão de maneira unilateral e truncada. Os mecanismos psicológicos que regem os deslocamentos, os desafios, e o desejo que incita a pessoa com deficiência a se lançar no espaço desconhecido em busca de uma realização, esse conjunto de emoçóes esbarra, sobretudo, no preconceito.

Toninho relata o ocorrido no ônibus:

Um motorista falou assim para mim:

- Senta ai, ceguinho.

Eu respondi:

- Eu tenho nome.

Dai ele disse:

- Mas eu não sei se você chama José ou Antonio.

E eu respondi:

- Você decide, qual é o meu nome, José ou Antonio?

Às vezes quando o motorista náo sabe o meu nome ele já diz:

- Para aí, corintiano!

Às vezes, eu pego um ônibus para Guarulhos, onde eu já conheço as curvas e os buracos, quando ele dá uns quatro pulos eu já falo:

- Opa, tá chegando.

E eu ouço falarem:

- Mas como ele sabe...!

Mas às vezes quando estou num lugar que eu não sei, eu peço para

o motorista avisar e ele fala num tom bem soturno:

- "Tá bom"

Roseli, presente à entrevista, observa: 
Tá bom, não me enche o saco, pergunta pra outro. Eu acho assim, todo mundo tem nome, o cara fala assim: o ceguinho vai descer. Será que ele fala: o gordinho vai descer? O gordo vai descer? Ninguém gostaria de ser chamado assim pela sua característica marcante.

Amaral $^{15}$ coloca, com a autoridade de sua própria experiência, que "cada um de nós que vive a condição de diferença/deficiência, precisa e quer ser reconhecido nela, mas não identificado com ela." [...] A diferença significativa gera estranhamento, desorganização e, imediatamente somos, como seres humanos, levados a identificá-la, mesmo que apressadamente, em algum construto que nos tranquilize - e para isso servem os preconceitos e estereótipos e a imputação de estigma”.

\section{Se sou diferente de ti, longe de te lesar eu te aumento ${ }^{16}$}

Em interessante obra que combina biologia e filosofia, Jacquard ${ }^{17}$ cita Saint-Exupéry e declara que a riqueza genética é feita da diversidade; reflete como esta constatação ultrapassa o campo da biologia: "A riqueza de um grupo é feita de seus rebeldes e mutantes", citando Edgard Morin. "Trata-se de reconhecer que o outro é precioso para nós na medida em que é diferente". O autor, Diretor do Serviço de Genética do Instituto Nacional de Estudos Demográficos de Paris - INED, aponta que a reflexão pede um reconhecimento de como o outro se torna precioso para nós, exatamente por ser diferente. Essa é uma lição da genética, e não uma atitude moral ou religiosa. Mas não se trata de uma questão de tolerância, já que tolerar é aceitar com desdém, é ser indulgente, o que já estabelece uma relaçáo de força, de superioridade de quem tolera e inferioridade, de quem é menosprezado. "A nossa necessidade superficial de conforto intelectual impele-nos a reduzir tudo a tipos e a julgar segundo a conformidade dos tipos. Mas a riqueza está na diferença.”

Os epidemiologistas britânicos Richard Wilkinson e Kate Picket ${ }^{18}$ analisam as questóes da desigualdade em recente publicação, mostrando que sociedades mais igualitárias possuem vida comunitária mais forte e

15 AMARAL, Lígia Assumpção. Pensando a deficiência como diferença. III Congresso sobre Educação Especial. Curitiba, 1999.

16 SAINT EXUPÉRY. Lettre à um otage. Èditions Gallimard, 1944. "Si je diffère de toi, loin de te léser, je t'augmente" p. 68. Referência investigada a partir de uma citação encontrada em JACQUARD, 1988 p. 155.

17 JACQUARD, Albert. Elogio da diferença. São Paulo : Martins Fontes, 1988 p155. Publicação original em francês: Éloge de la différence, 1978

18 WILKINSON, R. ; PICKET, K. The spirit level: Why greater equality makes societies stronger. Blumsburry Press, 2010, tradução minha 
mais coesa. Os autores apontam a dependência de drogas, obesidade, depressão, dentre 10 problemas sociais e de saúde que podem ser relacionados à desigualdade. A desigualdade corrói a confiança social e debilita a sociedade, afetando todos os cidadãos, pobres, ricos, com ou sem deficiência, bem sucedidos e excluídos.

O stress psicológico e a ansiedade seriam causados pelo baixo status social, pela falta de amigos e pelo stress na infância. Estudo realizado com funcionários públicos britânicos aponta que pessoas que exercem funçóes de pouco prestígio, como porteiros, mensageiros, estão mais propensos ao câncer, ao suicídio e às doenças cardíacas. Os autores discutem o efeito causado pela percepção da inferioridade, pela humilhação e sensação de não-aceitação. Esses sentimentos são comuns em vítimas de preconceito.

Montagu aponta experimento desenvolvido no departamento de psicologia da norte americana Swarthmore College, em Pensilvânia ${ }^{19}$ com estudantes de 18 a 25 anos. Levados para uma sala completamente escura, onde nada podia se ver, os estudantes tocavam-se, propositadamente, uns aos outros, diferentemente do que acontecia em sala iluminada, quando se mantinham distantes. $\mathrm{Na}$ escuridão, aproximadamente $50 \%$ dos participantes, alunos que náo se conheciam, abraçaram-se e em cerca de 30 minutos atingiram um estado de intimidade, raramente alcançado por pessoas com anos de conhecimento.

Outras experiências desenvolvidas com alunos vendados e que usavam apenas o tato para perceber o que acontecia à sua volta, chamam atenção para os valores relativos à visão, em comparação com os valores do tato, mostrando que:

Em seu aspecto social, a visão é o sensor dos sentidos. [...] o tato não tem qualidades reprobatórias. $\mathrm{O}$ tato é aberto e livre. Por assim dizer, a visão funciona como árbitro do comportamento, como inibidor dos estímulos que chegam até seu âmbito de alcance; o tato é isento de censuras, reprovaçóes ou inibições. (MONTAGU, 1986, p. 257)

Antropólogo e professor de anatomia, o inglês Montagu reflete que "a visão é o meio do preconceito perceptivo" e cita ainda o Dr. August F. Coppola ${ }^{20}$, colocando que [a visão] "é tão naturalmente considerada assim que poucas pessoas percebem a extensão em que a maioria dos nossos preconceitos está delimitada pelo modo como vemos as coisas":

19 Deviance in the dark. Disponível em: http://www.swarthmore.edu/Documents/faculty/gergen/Deviance_in_the_dark. pdf. Acesso em 31/12/2011

20 A.F. Coppola. Reality and the Haptic World. Phi Kappa Phi Journal, Winter 1970, pp.14-15. In MONTAGU, Ashley. Tocar. O significado Humano da Pele. São Paulo : Summus Editorial, 1986 


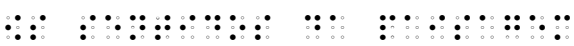

É quase uma blasfêmia dizer isso, mas o culpado no caso é a visão que dita a maioria de nossos valores e domina praticamente todos os aspectos de nossa sociedade. A cor da pele, a ostensiva manifestação de riqueza, a classificação das pessoas por seu vestuário e aparência, são todas condutas baseadas em distinções que a visão nos torna possíveis. Para sermos aceitos, devemos nos enquadrar no mundo visto, mesmo que sejamos cegos. (MONTAGU, 1986, p. 259)

Mas, pode-se encontrar atitudes preconceituosas também entre pessoas que não enxergam com os olhos, como nos mostra Toninho. Quando foi reclamar sobre a falta de acessibilidade em um banco, comentou o fato com outros deficientes visuais, e estes náo acreditaram que ele poderia conseguir mudanças.

Falei que ia acionar o Ministério Público, riram na minha cara. O banco tem o cartão chave de segurança. Toda vez que uma pessoa acessa a sua conta pelo telefone para fazer uma transferência, um pagamento, o número de segurança é diferente. Eles náo pensaram nos deficientes visuais, diz Toninho. Eu tenho que fazer um cadastro e na tela deles aparecer um simbolo. Como o sistema deles é falho, ou eles não fizeram isso, eu fui reclamar no PROCON. Eles não quiseram me atender para fazer reclamação e eu disse a eles que eu sou um cliente, porque não aceitar a reclamaçâo? Disseram que não podiam obrigar o banco. Eu respondi: - Você náo obriga nada, você tem que aceitar a minha reclamaçáo porque eu sou um consumidor e aqui é um órgão público. Você term código de defesa do consumidor? Para que ele serve? Mandei chamar o supervisor e depois de muita briga aceitaram a reclamaçâo. Daí, mandaram para o banco e eles fizeram vista grossa. Mandei então para o Ministério Público. Agora eles disseram que até 13 de setembro iam criar uma tal de chave de segurança. Eu falei para o Ministério Público estipular um prazo e se o banco não cumprir, enquadra ele e acabou. Um monte de gerentes, dizem que dão aulas para os gerentes, mas não tem gerente deficiente visual lá. E eu fui o único a reclamar. Outro deficiente visual deu risada na minha cara e eu falei: - Você é um cidadão ou um projeto de cidadão? Falei mesmo, porque ele não acreditou em mim.

Roseli comenta que percebe um problema sério, que é o do preconceito entre as próprias pessoas com deficiência: 
Existem pessoas com deficiência que trabalham e fazem pouco caso de outras pessoas com a mesma deficiência delas. Isso é muito sério porque as próprias pessoas com deficiência visual têm preconceito. O que você contou agora já aconteceu comigo nessa mesma empresa, um dia eu fui trocar a senha do programa com sintetizador de voz ${ }^{21}$ que utilizo e eles falaram que não podia trocar naquela hora. E então eu falei que ia lá naquela hora, para trocar a senha. Ai ele, o atendente, mudou a conversa, falou: tá bom, então tá, aqui tá a senha. Por que as pessoas agem assim? As pessoas têm preconceito contra os próprios deficientes visuais, acham que a gente não sabe de nada, e acham que deficiente visual é amigo, companheiro um do outro...

Toninho completa:

Sobre isso que a Roseli falou, aconteceu um fato comigo. Fui a Osasco para fazer um exame para auxiliar de câmara escura, era final de 1992. Aí, como eu ainda ia concluir o $1^{\circ}$ grau eu não consegui fazer porque ainda estava me formando.

E a moça que fazia as inscriçóes também era deficiente visual e falou:

- Quem manda você ser "vagal" (vagabundo) e não estudar.

E eu respondi:

- Péra aí, só porque você estudou no Padre Chico você não pode falar assim.

E dai, pensei, agora eu vou "zoar":

- Eu tenho máquina braille e você tem² ${ }^{22}$ Você não tem, não pode me julgar sem ser meu parente, sem conhecer minha situação. Não pode dizer que eu sou "vagal" só porque eu já tinha mais de 20 anos e não tinha me formado.

Crochík ${ }^{23}$ aponta que o pensamento por meio de clichês fragmenta o mundo de forma classificatória: bom/mau, perfeito/imperfeito, útil/inútil. É desta maneira que a própria realidade se organiza, de forma esquemática, como os processos de produção. Toninho valeu-se do recurso de possuir uma

21 Pessoas com deficiência visual contam com o recurso de programas de informática com sintetizador de voz para usar o computador.

22 Possuir máquina de escrever em braille, no Brasil, pode ser sinônimo de status social, já que até poucos anos atrás a máquina era importada ao custo aproximado de US\$ 1.000,00. Atualmente a máquina é montada em Sáo Paulo, com peças importadas, mas ainda continua inacessível para a maioria das pessoas, que escrevem em braille usando um pequeno gabarito de metal ou plástico chamado "reglete".

23 CROCHÍK, José Leon. Preconceito, Individuo e Cultura. São Paulo : Casa do Psicólogo, 2006 p24 


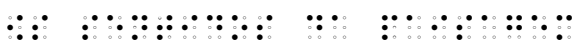

máquina manual para a escrita braille, mais comumente encontrada em instituiçóes, para responder à moça que exibia para ele o fato de já ter concluído o curso.

Isso que você está contando, reflete Roseli, é um preconceito intra-deficiência, é complicado e é engraçado que esse preconceito não é sentido só com deficientes da mesma categoria, mas com outros de outras categorias. Por exemplo, quando eu comecei a fazer teatro eu tive que me deparar com os cadeirantes e o mais interessante é que eles não encostavam nos cegos. Porque não sabiam como chegar, estranhavam. Era a tal da barreira atitudinal, aquela história de não saber como se aproximar. Eu ficava só observando. E eu ia cumprimentar eles e pensava, não quero nem saber, eu vou pegar neles, eu vou agarrar eles. E eles começaram a falar comigo. Enquanto outros ficaram num canto, eu fui lá falar com eles e eles começaram a falar comigo. Eu percebi que há uma resistência muito grande entre as categorias de deficiências. Às vezes, as pessoas pensam que todos os deficientes se dão bem, que um cadeirante vai receber bem um cego, porque tem uma coisa em comum que é a deficiência. Não é bem assim. Não tem a ver com a deficiência e muitas vezes com a personalidade da pessoa e a forma de posicionamento apresentado perante a sociedade.

Tomando-se por referência Amaral, a questão da deficiência é parte de uma problemática ampla, das diferenças significativas. A psicóloga utiliza como referencial básico para conceituação da deficiência a proposta da Organização Mundial da Saúde - $\mathrm{OMS}^{24}$, do início da década de 80, como suplemento à Classifcação Internacional das Deficiências, Incapacidades e Desvantagens: um manual de classificação das consequências

24 Deficiência: perda ou anormalidade de estrutura ou função psicológica, fisiológica ou anatômica, temporária ou permanente. Incluem-se nessas a ocorrência de uma anomalia, defeito ou perda de um membro, órgão, tecido ou qualquer outra estrutura do corpo, inclusive das funções mentais. Representa a exteriorização de um estado patológico, refletindo um distúrbio orgânico, uma perturbação no órgão.

Incapacidade: restrição, resultante de uma deficiência, da habilidade para desempenhar uma atividade considerada normal para o ser humano. Surge como consequência direta ou é resposta do indivíduo a uma deficiência psicológica, física, sensorial ou outra. Representa a objetivação da deficiência e reflete os distúrbios da própria pessoa, nas atividades e comportamentos essenciais à vida diária.

Desvantagem: prejuízo para o indivíduo, resultante de uma deficiência ou uma incapacidade, que limita ou impede o desempenho de papeis de acordo com a idade, sexo, fatores sociais e culturais Caracteriza-se por uma discordância entre a capacidade individual de realização e as expectativas do indivíduo ou do seu grupo social. Representa a socialização da deficiência e relaciona-se às dificuldades nas habilidades de sobrevivência.

Fonte: Portugal. Secretariado Nacional de Reabilitação.Classificação Internacional das Deficiências, Incapacidades e Desvantagens (Handicaps): Um manual de classificação das consequências das doenças (CIDID). Lisboa: SNR/OMS; 1989. 
das doenças. Amaral indica dois grandes avanços: a distinção entre doença e deficiência e o desmembramento do conceito de deficiência em deficiência, incapacidade e desvantagem, apontando a síntese conceitual:

Deficiência (impairment) refere-se a uma perda ou anormalidade de estrutura ou função: como por exemplo, podemos pensar num nervo ótico lesado.

Incapacidade (disability) refere-se à restrição de atividades em decorrência da deficiência: em nosso exemplo seria o não ver.

Desvantagem ( handicap) refere-se a condição social de prejuízo resultante de deficiência e/ou incapacidade: na ilustração que estamos usando seria o conjunto de significados da cegueira e suas consequências psíquicas e interpessoais.

Amaral (1999) propóe um desdobramento da deficiência, como fenômeno global, em dois sub-fenômenos, o da Deficiência primária (deficiência e incapacidade) e o da Deficiência secundária (desvantagem). Aponta que a primeira se remete a "aspectos descritivos, intrínsecos" e a segunda a "aspectos relativos, valorativos, extrínsecos”. Em relação a esta, reflete que a ideia de desvantagem nos remete a contingências preponderantemente sociais, "tais como sistema econômico, organização política, crenças e valores, leituras e interpretaçóes sociais, e, em consequência, a um conjunto de açóes/reaçóes ao fenômeno deficiência e às pessoas que o corporificam". E registra a relativizaçáo inerente na ideia da desvantagem, lembrando que "só se está em desvantagem em relação a algo ou a alguém”. Essa desvantagem é motivo de impedimento para o desenvolvimento de uma vida plena e encerra a pessoa com deficiência numa situação que é constituída de barreira de atitudes, muito mais do que as barreiras causadas pela própria deficiência. São estes os fenômenos psicossociais ligados às questóes da deficiência e da diferença, que como define a autora, são os preconceitos, os estigmas.

Segundo Sekkel

A cultura opressiva prima anacronicamente pela autoconservação e constitui a lógica que circunscreve as relaçóes sociais fundamentadas sob o domínio do medo e da força coercitiva coletiva. [...] Os indivíduos imersos na cultura da violência expressam formas irracionais de escapar à ameaça da não-integração social e acabam por corroborar a manutenção da racionalidade que os aprisiona, racionalidade que se assenta em relaçóes sociais excludentes e no menosprezo pelos mais frágeis. Irradiando a destruição levada 
a cabo cegamente, as expressóes de exclusão social afastam o medo particular de ser o próximo alvo. Assim, os frágeis devem ser afastados, por vezes humilhados e maltratados, pois, aos olhos dos agressores, portam signos da adaptação malsucedida, da natureza náo dominada. (SEKKEL; CASCO, 2008, p. 24)

Toninho explica que com frequência é tratado como parte de um grande grupo, só pelo fato de ter a mesma deficiência.

Outro dia entrei no metrô e alguém falou:

- Tem um coleguinha seu aí.

E realmente tinha um deficiente visual, era meu irmão (ri). Ele não sabia que era eu e eu reconheci que era ele pelo modo dele assobiar e pelo perfume que ele estava usando.

Pela reflexão de Amaral (1994), "a pessoa estigmatizada passa a ser vista tão somente pela condição geradora do próprio estigma [...] deixando então de ser pessoa, passa a ser a diferença/deficiência”. Quando perdem a visão, pessoas cegas perdem a sua identidade e frequentemente são consideradas incapazes pela sociedade. É comum quando alguém quer oferecer algo a uma pessoa cega, dirigir-se ao seu acompanhante. $\mathrm{O}$ fato acontece com frequência em estabelecimentos comerciais, lojas, restaurantes, locais onde pessoas cegas são muitas vezes tratadas como incapazes de tomar decisóes ou fazer escolhas de maneira independente.

Nos depoimentos os protagonistas relatam diversos tipos de reaçóes de cidadãos: o estranhamento que acontece em razão do preconceito, da falta de hábito de conviver com o diferente, o medo de se aproximar e ofender, e mesmo do desconhecimento total da deficiência. Vicente comenta também a reaçáo das pessoas quando assistiam à novela América, da Rede Globo, em que um dos personagens da história era cego:

\section{[...] Eu não sou muito de TV, mas a novela América chocou a princípio, mas trouxe} muitos beneficios. O pessoal sempre lembra e na época vinha brincar, puxava assunto, dizia que pensava que era de outro jeito e foi um meio para a gente puxar conversa e falar o que é melhor para a gente, como atravessar a rua. O pessoal já está mais à vontade, já tem ideia de oferecer o braço. Acho que tudo é um princípio e nesses últimos dois anos teve um avanço muito grande, o pessoal tem demonstrado querer aprender. Acho que as pessoas com deficiência deveriam ser mais engajadas em suas reivindicaçöes, principalmente as lideres de instituiçóes mostrando a cada pessoa com deficiência 
que precisamos ocupar nosso espaço na sociedade como cidadãos tanto na hora das reivindicaçóes quanto na dos deveres senão as coisas não mudam. Acredito que exigências como cardápio em braille, acessibilidades arquitetônicas e a lei de cotas deverão passar por um trabalho de conscientização liderado pelo governo com participação de pessoas com deficiência, facilitando a inclusão, para que essas açóes não venham a despertar a antipatia dos donos de estabelecimentos para com as pessoas com deficiência, já que a instalação desses benefícios envolve custos.

Também sobre a falta de conhecimento da população, há a reflexão do educador Vieira ${ }^{25}$, ex-diretor do Instituto Benjamin Constant, do Rio de Janeiro, que comenta que o preconceito é, muitas vezes, consequência da falta de conhecimento das pessoas. O pesquisador colheu depoimentos de 89 alunos e constatou que a carga mais pesada para o aluno com deficiência visual náo é necessariamente a cegueira, mas sim a maneira preconceituosa como ele é considerado pela sociedade.

\section{Invisuais ${ }^{26}$ ou invisíveis?}

O cidadão adulto, ao adquirir a deficiência, perderia a sua autonomia e poder de discernimento, ficando limitado à condição de uma pessoa com deficiência, privado de sua cidadania e do papel social que exercia anteriormente. Nesse sentido, Malu relata o preconceito e a desinformaçáo dos atendentes:

Eu já fui a restaurante rodizio e percebi que o garçom vinha, passava na mesa do lado servindo e na minha ele não vinha. O meu colega pediu então para falar com o gerente. E disse que estava reclamando, pois ia pagar igual todo mundo e não estava sendo bem atendido como os outros que estavam ali. Ficou a desejar. Quando vou com quem enxerga, às vezes o garçom pergunta para o outro o que eu vou querer. Igual no médico, que fica perguntando para o "alguém"que está ao seu lado e não para você. Aconteceu com a minha amiga e ela disse:

- Olha aqui, quem é o doente sou eu, você tem que perguntar para mim!

25 VIEIRA, Carmelindo de Souza. Alunos cegos egressos do Instituto Benjamin Constant no periodo de $1985-90$ e sua inserção comunitária. Tese de doutorado defendida 2002, no Instituto Fernandes Figueira, Fundaçáo Oswaldo Cruz. Rio de Janeiro

26 "Invisual" é um adjetivo comumente usado em Portugal para definir pessoas cegas 
A falta de informação da sociedade, considera Vieira, faz das pessoas cegas incapazes, tratadas como crianças, com suas mães sendo obrigadas a responder por elas, sendo raras as vezes em que as pessoas se dirigem à pessoa cega, e não ao seu guia ou interlocutor. A esse respeito, Ricardo, bibliotecário, sendo ele próprio cego, comenta que a postura da família é determinante na sociabilidade das pessoas com deficiência:

Na biblioteca nós temos cegos com tudo o que é forma de agir. Temos cegos que vêm acompanhados das mães. Cegos adultos. Ele quase não fala, a mäe pede os livros por ele, que ele precisa para estudar e ela fala por ele. A gente incentiva que ele fale e ele acaba, depois de algumas vezes, alguns falam e outros não. Ou seja, o problema acontece antes, isso que acontece na biblioteca é o reflexo; é o problema familiar, como a família lidou com a deficiência, como ela preparou o cego para a sociedade, um trabalho antes. E existem casos de cegueira congênita, adquirida, então tem uma série de coisas, como a família reagiu, essa interação com a familia é um fator determinante para que ele se comporte na sociedade de determinada forma. Se há preconceito em casa e ele é considerado incapaz e tudo é trazido em máos, ele acaba chegando à conclusão de que ele precisa ser servido pela sociedade. Ou existe excesso de protecionismo ou existe uma rejeição muito acentuada.

Nesse sentido, Queiroz (1986, p. 91) reflete sobre a superproteção da família, que faz com que tudo chegue pronto às mãos da pessoa cega e, em diálogo com a mãe, ironiza sobre a preocupação com os perigos da independência:

- E se você bater num poste, cair num bueiro, for atropelado, o que vai ser de mim? (mãe) - Nesse caso, mamãe, seria o que vai ser de mim, e não o que vai ser da senhora. (QUEIROZ, 1986, p. 91)

Expressôes como "Infelizmente, meu primeiro filho é deficiente; mas o segundo é normal" nos mostram que muitas vezes o preconceito começa com as palavras e que isso pode acontecer já no âmbito familiar. Sassaki ${ }^{27}$ mostra que as palavras são expressóes verbais criadas a partir de uma imagem que a

27 SASSAKI, Romeu Kasumi. Trabalho publicado no livro Mídia e Deficiência, da Agência de Notícias dos Direitos da Infância e da Fundação Banco do Brasil (Brasília, 2003, p. 160-165) 
nossa mente constrói. Pensamos na pessoa com deficiência a partir de uma interpretação que nos leva a construir imagens. $\mathrm{O}$ autor faz uma relação das palavras que em si já carregam preconceito:

Apesar de deficiente, ele é um ótimo aluno.

Ceguinho (o diminutivo indica que o cego não é considerado uma pessoa completa)

Ela é cega, mas mora sozinha.

Aquela familia carrega a cruz de ter um filho deficiente.

Sobre a postura de sua família, Toninho esclarece:

Encara com a maior naturalidade. No início achavam que eu não ia conseguir fazer orientaçâo e mobilidade pela minha estatura, (tem 1,40m de altura), pela deficiência visual que tenho, achavam que não ia conseguir manejar a bengala por causa do meu braço, já que tive uma fratura aos 4 anos de idade. Mas eu não tenho só o braço direito, eu tenho o esquerdo também! Tanto é que eu uso a bengala mais com o esquerdo. Sou destro, para escrever braille, para pegar o copo.

Mas não são todas as pessoas que tratam a deficiência com naturalidade. Prestes a terminar a entrevista, Toninho faz o seu relato mais pungente.

A Silvia não vai acreditar, outro dia um motorista da linha que eu mais utilizo, Jardim Romano, Metrô - Penha 273, falou pra mim que ele detesta quando entra esses montes de aleijados e cegos que deveriam ser usados para fazer sabão.

Pergunto se ele não fez uma denúncia. Toninho responde que naquela época estava sem ninguém ao lado, não tinha como anotar o número do carro.

Eu adoro sentar do lado de uma pessoa porque se eu perceber alguma coisa, eu já fico com o gravador em ponto de bala, para náo perder nada. Agora que tenho celular já posso anotar algum número para não perder; ou senão já fico com ele prontinho, pergunto qual é o

A relação completa pode ser encontrada em: http://sentidos.uol.com.br/canais/materia.asp?codpag=8322\&canal=opiniao. 
número? E já pego 156 e já encaminho protocolo e tudo. Não sei se vai adiantar alguma coisa, mas tem uma frase que eu sempre gosto de usar: agindo com dignidade eu posso até não consertar o mundo, mas fico com a certeza de que na terra tem um canalha a menos.

Ouço o relato de Toninho e reflito sobre a simbologia das cores. Hoje, não é raro encontrar tecidos tingidos com smart pigments, fotocromáticos, sensíveis à luz. Roupas podem mudar de cor quando a pessoa sai de um ambiente interno e se expóe à luz do sol. Seria interessante imaginar um tecido cuja mudança de cor fosse acionada pelos sentimentos: em seus dias serenos as pessoas estariam de azul, pessoas que estivessem preocupadas apareceriam de cinza e certamente as atitudes de preconceito tingiriam a roupa da pessoa preconceituosa de vermelho, carmim-envergonhado.

Cidadãos, somos responsáveis pela construção de uma cidade mais amigável, assim como pelas atitudes de inclusão, que permitem a convivência de todas as pessoas indiscriminadamente, sem rotulação, sem juízo de valor.

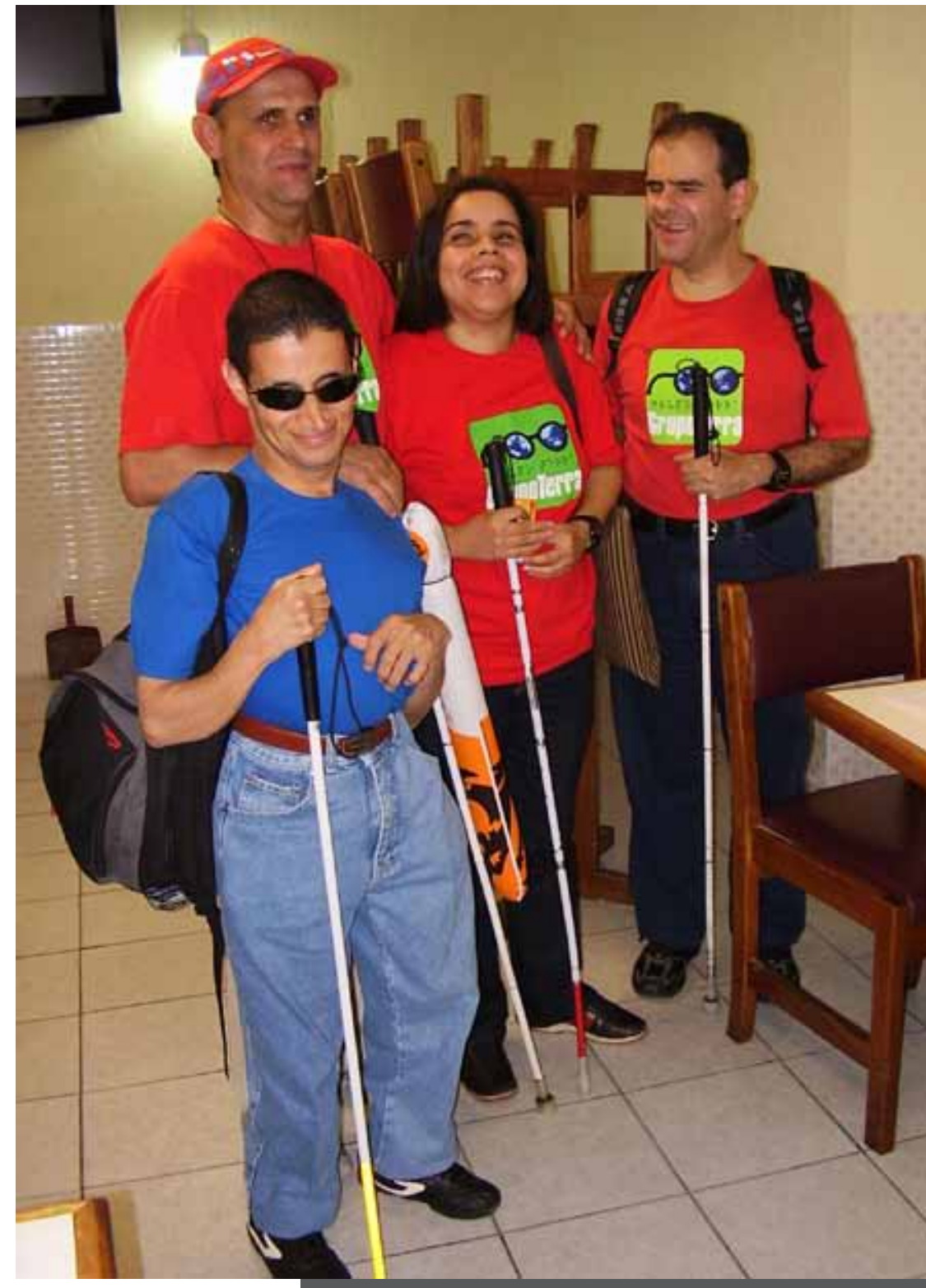

Toninho, Vicente, Roseli e Mário 



\section{O LADO DE DENTRO}

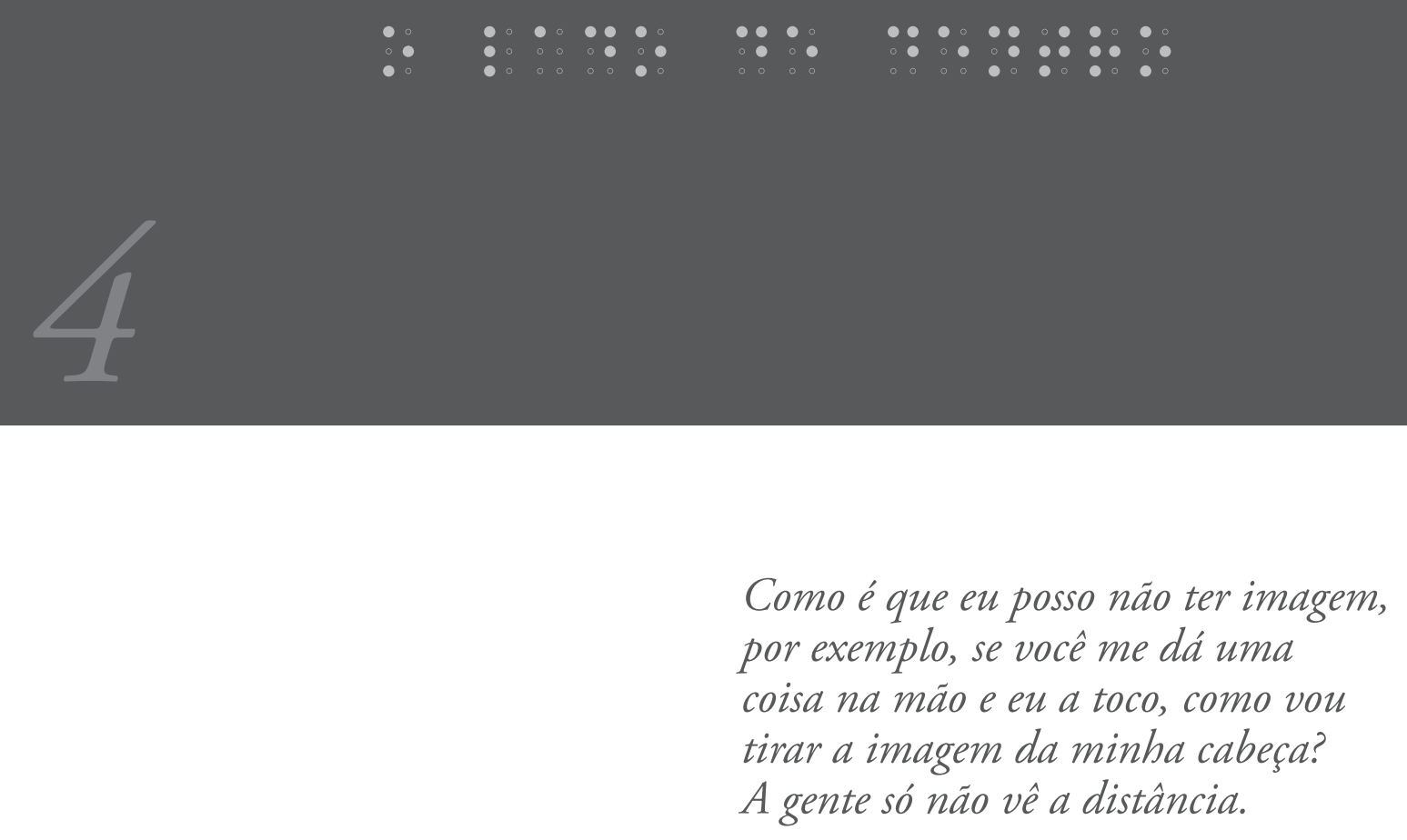

Juliana

São cinco horas da tarde e Juliana liga do Rio Grande do Sul, dizendo que tem uma coisa muito interessante para contar:

Tinha um perfume que eu gostava muito e ai ele terminou. E eu näo comprei mais. Comprei outro parecido, e eu me lembro bem do frasco, da tampa, até agora eu me lembro. Dai, esses dias, eu estava tentando me lembrar, porque eu queria comprar de novo esse perfume. E não me vinha mais, não me vinha como era of frasco dele e eu estava deitada, era de noite, e eu fiquei pensando naquilo... Meu Deus do céu como é o perfume! Mas, olha que interessante, por isso é que eu acho que deve existir alguma imagem na nossa memória, mesmo que a gente näo enxergue, não tenha a visäo. Para quem nunca enxergou, deve existir alguma 
outra coisa gravada, que eu não sei explicar. Porque dai eu parei assim e não me lembrava dele. Dai vinham outras formas na cabeça, sabe, na verdade não na cabeça, é como se fosse uma memória sinestésica, eu me lembrava daquilo e parecia que eu pegava naquilo, sabe, segurando na mão. E me lembrava de outros frascos, outras milhares de tampas, outros frascos diferentes, de tamanhos diferentes, com textura, sem textura, lisos, eu ia passando a mão, e eu via o todo do vidro, eu náo via só a tampa, eu pegava o vidro na mão, inteiro, é estranho, eu não tinha parado para perceber isso. E depois de um tempão eu disse, meu Deus, mas como é que era aquele vidro, e fiz um esforço e dai ele voltou na minha mente. Voltou na minha mão, na verdade, voltou como se eu estivesse sentindo ele de novo, eu peguei ele na mão, me lembrei da tampa, de como ele era, do formato, tudo, dai ele voltou, VOLTOU! Interessante, né? Eu nunca parei para perceber isso, por isso é que eu acho que deve existir, sabe, se a gente for estudar mais a fundo, nem sei que área estuda isso, deve existir uma imagem, alguma coisa, porque se, mesmo que a gente lembra das coisas, mesmo que a gente náo pegue elas na mão, tem uma imagem gravada ali, né? Na verdade eu queria entender, porque eu tenho certeza que me lembro da imagem, senão eu não me lembrava da tramela da casa da minha avó, porque a imagem, ela não vem do olho, ela é sinestésica, ela vem através das sensaçôes, ela vem como se fosse o frio, o quente, como se eu estivesse pegando na mão aquela coisa, sabe? É lindo, né? Eu queria entender, na verdade, eu tenho certeza que tem imagem. Eu acho que na verdade a gente tem imagem, mas não tem como externar a imagem. Não é que a gente não tem como externar: como a gente não enxerga, quem nunca enxergou não tem isso, não sabe como é enxergar; porque o cérebro interno está normal, é o nervo ótico que não tem a ligação, o cérebro em si forma imagem, ele está percebendo uma outra coisa que acontece, lendo uma outra imagem. Eu fiquei louca pra te contar isso, pensei em te chamar às três da manhä!

As mãos transmitem emoçôes, consolam, apertam, acariciam. Quando tocamos algo, acionamos uma trama complexa de sensores, desencadeando sensaçóes que são imediatamente decodificadas pelo cérebro como quente, frio, suave, áspero, liso, duro, macio, denso, oco, pesado, leve, pontiagudo. Ackerman ${ }^{1}$ relata que em um hospital de Miami, voluntários acariciam bebês prematuros que, mesmo nas incubadoras, ganham peso $50 \%$ mais rápido do que se não forem massageados.

1 ACKERMAN, Diane. Um história natural dos sentidos. Rio de Janeiro : Bertrand Brasil, 1992 
A autora cita artigo de 1988 do jornal norte-americano New York Times sobre a importância do toque no desenvolvimento infantil, notando: "atraso no desenvolvimento psicológico e físico das crianças privadas do contato físico, mesmo que sejam bem alimentadas e cuidadas" e aponta pesquisa que investigou o comportamento de órfãos da Segunda Guerra Mundial:

Bebês prematuros que foram massageados durante 15 minutos, três vezes por dia, ganharam peso $47 \%$ mais rápido do que os que permaneceram sozinhos em suas incubadoras. As crianças massageadas também demonstraram sinais de que seu sistema nervoso amadurecia mais rapidamente: tornaram-se mais ativas, reagindo melhor às coisas, como um rosto ou um ruído, [...] e podiam deixar o hospital em média seis dias mais cedo do que as outras. ACKERMAN, 1992, p. 101

O toque auxilia no desenvolvimento infantil e é muito mais forte do que o contato verbal; nos afeta a todos, crianças ou adultos. Pacientes que sobreviveram a ataques cardíacos, sejam eles casados ou solteiros, têm maior sobrevida ao conviver com animais de estimação. Ackerman cita experiência realizada na Filadélfia, que constata que o ato de acariciar animais é calmante e apresenta efeito curativo. E cita um dos pesquisadores: "Criamos nossos filhos em uma sociedade não-tátil e temos que compensar essa carência com criaturas não-humanas. Primeiro com ursinhos de pelúcia e cobertas, depois com animais de estimação. Quando não existe o toque, surge nosso verdadeiro isolamento". A autora lembra que o toque é terapêutico tanto para a pessoa que toca, quanto para a que é tocada.

Experiências investigando o toque subliminar foram desenvolvidas em restaurantes em Oxford e no Mississipi, em cabine telefônica em Boston e em biblioteca de Purdue University, em West Lafayette, Indiana. Ackerman explica que, em Purdue, a pesquisa consistia em tocar os usuários da biblioteca de maneira sutil: a bibliotecária, ao entregar o cartão da biblioteca ao usuário, sem sorrir, esbarra levemente em sua mão. Ao avaliar a biblioteca, mais tarde, o usuário é convidado a dizer se a bibliotecária naquele dia sorriu para ele ou o tocou. $\mathrm{O}$ estudante geralmente declara que a bibliotecária sorriu para ele, e não o tocou. Depois dessa experiência, os estudantes demonstram maior satisfação com a biblioteca.

Ao refletir sobre o trabalho das mãos, a autora conta a história de uma cabeleireira da Pennsylvania. Casada, mãe de cinco filhos, cega em consequência de uma retinopatia, decidiu, já madura, exercer a função para a qual sempre teve inclinação. Passou por um treinamento para aprender a cortar cabe- 
los, tomando por referência o formato da cabeça do cliente, enquanto cortava o cabelo por camadas. Aprimorou-se de tal maneira, que acabou contratada por quem a treinou.

"A mão move-se com precisão complexa que não pode ser substituída" (ACKERMAN, 1992, p. 150). As mãos escrevem, desenham, os dedos são capazes de ler a escrita braille. Pessoas se cumprimentam com apertos de mãos, cobrimos o rosto para chorar, "as mãos são as mensageiras de emoção". A autora mistura poesia e ciência ao explicar o toque e as mensagens mediadas pelas mãos; e apresenta como RILKE ${ }^{2}$ descreve a arte de Rodin:

Rodin fez mãos pequenas, independentes que, sem fazerem parte de um corpo, mesmo assim são vivas. Mãos elevando-se para as alturas, zangadas e irritadas; mãos cujos cinco dedos eriçados parecem latir como as cinco gargantas de Cérbero. Mãos em movimento, mãos adormecidas e máos no ato de acordar; mãos criminosas com o peso da hereditariedade, mãos cansadas que perderam todo o desejo, caídas como um animal doente jogado a um canto, sabendo que ninguém as poderá ajudar. Mas as mãos formam um organismo complicado, um delta para o qual flui grande parte da vida de fontes distantes e das quais são derramadas como ampla corrente de ação. As mãos possuem história própria, civilização pessoal, beleza especial; nós lhe concedemos o direito de ter seu próprio desenvolvimento, seus desejos, sensaçóes, ânimos pessoais e ocupaçóes favoritas. (ACKERMAN, 1992, p. 151)

\section{Os espaços da memória}

Juliana, cujas mãos memorizaram a forma do frasco de perfume, terminou recentemente o curso de Letras em universidade gaúcha. Nada, anda de bicicleta, pratica canoagem, rapel e outros esportes radicais; faz cerâmica, toca piano e domina o espaço interno da casa, por onde corre com segurança. Bebê prematuro, teve perda de visão nos primeiros dias de vida, ainda na incubadora. Tinha três anos quando resolveu mudar-se para a casa da avó:

Até hoje eu me lembro da casa da minha avó. Ela guarda aspectos antigos de antes da reforma, eu me lembro de tudo exatamente como era. Quando eu tinha três anos, eu

2 RILKE, Rainer Maria. Where silence reigns : Selected prose. New York : New Directions, 1978 In: ACKERMAN, Diane, 1992 


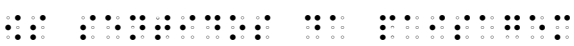

passei seis meses lá na casa da minha avó e não queria voltar pra casa, fiquei morando lá. Não sei por que, eu queria ficar lá. Minha mãe me contou, eu não lembro. Eu vivi toda a minha infância lá, brincava com meus primos, os natais eram lindos, tinha um salão imenso, onde agora são os consultórios; ah! coisas muito bonitas. Eu vivo até hoje sempre na minha avó. Ela mora na mesma casa, em cima da clinica. Tem coisas que ainda se preservam, naquela casa. Ela foi reformada, mas ainda tem coisa do que ela era, sabe? Não vou sozinha para lá, a gente vai de carro porque é longe. A parte de fora, se eu fosse descrever ela hoje eu me lembro bem: tinha a entrada, um portão de madeira, bem baixinho, com tirinhas, e na casa tinha uns degraus, um pedacinho de calçada, era só uma calçada bruta assim, de cimento bruto. Ah, eu adorava aquilo! Até hoje quando eu entro lá eu ainda penso que eu vou pisar naquele cimento. Hoje eu vou pisando na lajota, me dá uma sensação tão estranha, parece que eu tinha que pisar no cimento, não na lajota. É estranho. Agora tem menos árvores, tem a garagem agora, que antes não tinha; muita coisa que ficou pra gente.

Para Juliana, a casa da avó era um espaço de especificidades singulares, ambiente mágico de conquistas e capacidades; adentrá-lo significava esquecer lá fora as diferenças. O primeiro degrau da escada da casa da avó era para a menina a plataforma de entrada de um campo de conquistas. A textura do piso ficou impregnada de lembranças gravadas no cimento grosso, fazendo do primeiro passo um gatilho desencadeante de emoçóes.

Lembro até da fechadura da cozinha antiga, da tramela italiana (pergunta se eu sei o que é tramela), a porta ainda é a mesma. A porta que tinha tramela era a do banheiro. Era assim, não tinha fechadura e tinha a tramela por fora e uma tranquinha por dentro. Quantas vezes os meus primos me trancavam lá dentro e eu trancava eles lá, botava a tramela pelo lado de fora... Aconteceu uma vez só que eu fiquei trancada lá, eu tinha medo. A cozinha tinha um piso liso, não era lajota (agora é lajota) e era um pouco irregular, tinha uma parte que era baixada, embaixo, no cimento. Tinha uma porta que até hoje existe, tinha uma fechadura de ferro antiga que é linda, linda, uma tranca embaixo, maravilhosa, meu Deus, é linda! Eu me lembro dos balcóes, de tudo, porque eu ia arrumar sempre a mesa, então me lembro dos pratos, dos balcóes, tudo, tudo, dos copos como eram. Agora ela está morando lá em cima. 
A porta com a fechadura, hoje relembrada com o frio do ferro, confirma que da casa em que moramos, o trinco ficou em nossas mãos e os menores gestos gravados em nós, vivos, perfeitos. "Habitar oniricamente a casa natal é mais do que habitá-la pela lembrança; é viver na casa desaparecida tal como ali sonhamos um dia" (BACHELARD, 1993 p. 35).

$\mathrm{O}$ autor descreve como qualquer espaço habitado, por mais humilde que seja, transforma-se em moradia e traz a essência da noção de casa. Segundo o autor, a imaginação constrói paredes de sombras e com tal, a ilusão de proteção, além de poder, por meio de pensamentos e sonhos, viver a casa em sua realidade.

Os verdadeiros bem-estares têm um passado [...]. A casa, como o fogo, como a água, nos permitirá evocar, na sequência de nossa obra, luzes fugidias de devaneio que iluminam a síntese do imemorial com a lembrança. Nessa região longínqua, memória e imaginaçáo não se deixam dissociar. [...] Assim, a casa não vive somente no dia-a-dia, no curso de uma história, na narrativa de nossa história. Pelos sonhos, as diversas moradas de nossa vida se interpenetram e guardam os tesouros dos dias antigos. [...] Reconfortamo-nos ao reviver lembranças de proteção. (BACHELARD, 1993, p. 25)

A casa da infância ficou inserida em nós, diz o autor, indicando que mesmo depois de décadas temos gravada a cinestesia que nos torna capazes de subir as escadas sem tropeços. Cita também observação de Minkowska, no desenho de uma criança, apontando que na porta há "uma maçaneta, entramos nela, moramos nela". E completando: "No reino dos valores, a chave fecha mais do que abre. A maçaneta abre mais do que fecha" (BACHELARD,1993, p. 85). "Empurraríamos com o mesmo gesto a porta que range, iríamos sem luz ao sótão distante. [...] Cada um dos redutos foi um abrigo de devaneio" (BACHELARD, 1993, p. 34).

Sandra faz uma viagem no tempo para registrar os encantos do colégio da sua infância, as portas de ferro, batentes, janelas, maçanetas. Na sua lembrança manifesta-se novamente o afeto pelo espaço que considerava seu, espaço de intimidade, como se fosse sua própria casa.

As portas? Eram lindas. É a mesma, de ferro, com vidro, e aqui na lateral tem uma janela (Sandra encanta-se tocando as portas). O piso é branco com umas faixas pretas, ai, gente, que emoção! E as janelas, por todo o corredor, que coisa linda. Aqui dava para o pátio. Tinha um dos meninos e outro das meninas e pra frente do pátio, no final dele, tinha um coberto, bem menor que é este que é descoberto. E as portas são de madeira de Pinho de Riga, 
meu pai contava. E tinha umas bandeiras enormes em cima e os números. E as portas que ficavam aqui no hall da escada eram escuras e as outras todas são claras. Continua tudo igual?

Merleau-Ponty observa que não prestamos atenção aos objetos que nos rodeiam. Ao abrirmos uma porta, não prestamos atenção à maçaneta, mas sim no que encontraremos ao entrar. Se desenvolvêssemos o hábito da atençáo no agora, nas portas e maçanetas, elas seriam desenhadas para acolher melhor nossas mãos. No depoimento de Sandra, no Colégio Caetano de Campos, a maçaneta é acariciada como objeto de afeto. E náo apenas a maçaneta, mas cada detalhe do colégio: as pastilhas do cháo, os ornamentos de metal do corrimão, a textura dos assentos do teatro. A professora preza a escola que a acolhia, valorizava, encantava, abria-se para ela. Pallasmaa registra que "a pele lê a textura, o peso, a densidade e a temperatura do assunto. É prazeroso apertar a maçaneta da porta, brilhante pelos milhares de mãos que já entraram pela porta antes de nós. A maçaneta é o apertar de mãos do edifício." (PALLASMAA 2008, p. 56, tradução minha).

Sandra sente o prazer a que se refere o arquiteto:

E as janelas são as mesmas, gente, isso aqui é igualzinho! A maçaneta da janela é a mesma, tem uma trava enorme, você abaixa uma alavanca, a gente levanta essa trava e abre os vidros. $E$ as classes todas têm janelas assim também e dependendo da sala era muito barulhenta, porque as salas que davam para a Avenida Ipiranga, daquele extremo, eram barulhentas.

A professora se refere ao Colégio Caetano de Campos quando este, na Praça da República, em Sáo Paulo, ocupava o edifício de feiçóes neoclássicas projetado em 1890 por Ramos de Azevedo. E relembra, hoje, os dias passados nas salas e corredores da escola e os caminhos que a levavam até lá. A visita rompe um hiato de 50 anos e em sua memória emergem emoçóes atemporais.

Em 1962, o local era descrito pelo Guia do Estado de Sáo Paulo ${ }^{3}$ como "uma das mais belas praças da capital, caracterizada pelo seu aspecto romântico, um verdadeiro oásis no meio dos edifícios". O Guia descreve os jardins projetados e plantados entre 1902 e 1904 e a Escola Normal, que deram vida e prestígio ao local.

Antigamente passavam carros! Tinha um jardim na frente do prédio e uma praça. No meio tinha uma rua onde passavam carro e ônibus. Tinha muito 


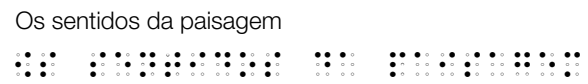

ponto de ônibus na lateral do prédio, olhando para ele na lateral direita e uma loja famosissima ali chamada Cássio Muniz. (Sandra)

Em Merleau-Ponty refletimos:

Quando evoco um passado distante, eu reabro o tempo, me recoloco em um momento em que ele ainda comportava um horizonte de porvir hoje fechado, um horizonte de passado próximo hoje distante. Portanto, tudo me reenvia ao campo de presença como à experiência originária em que o tempo e suas dimensóes aparecem em pessoa, sem distância interposta e em uma evidência última. É ali que vemos um porvir deslizar no presente e no passado. (MERLEAU-PONTY, 1994, p. 557)

Tuan (1980) registra que o sentimento de amor pelo lugar está diretamente atrelado à consciência do passado. Também nas memórias da professora podemos perceber o afeto pela riqueza das experiências vividas na infância. Conferimos portas de vidro, grades, superfícies de mármore, arcos, colunas. No discurso de Sandra, cada elemento do edifício é dotado de significado.

Onde está o busto que ficava aqui? Não tem mais? Ah! (decepção) o que fizeram! A escada principal da frente do prédio tem um lance de uns 15 degraus mais ou menos e depois tinha um hall e depois a escada se dividia, um braço para cada lado, com lances separado, ficava um charme. Os corrimãos eram bem largos, a parte de cima de madeira e as laterais eram de ferros, se não me engano. Os bancos eram largos, e a estrutura de ferro. O corrimão é madeira e na lateral é de ferro, eu acho lindissimo. A escada, se você perceber bem com o pé, assim, (esfrega o pé no piso) ela tem até uma depressão, um gasto, e aqui bem na frente tem uma coisa que eu acho que é um crucifixo (hoje substituido por uma escultura de duas pessoas sentadas; um funcionário confirma que era antes um crucifixo). A parede era toda assim, com textura macia, que náo machuca. Do primeiro para o segundo andar é igual, tem um corredor enorme. Mas o piso não era esse! (estamos em uma área de piso diferente, mas ela logo localiza com a bengala o piso original, de pastilha) Este aqui, todo bege e de vez em quando não tinha umas coisinhas escuras? 

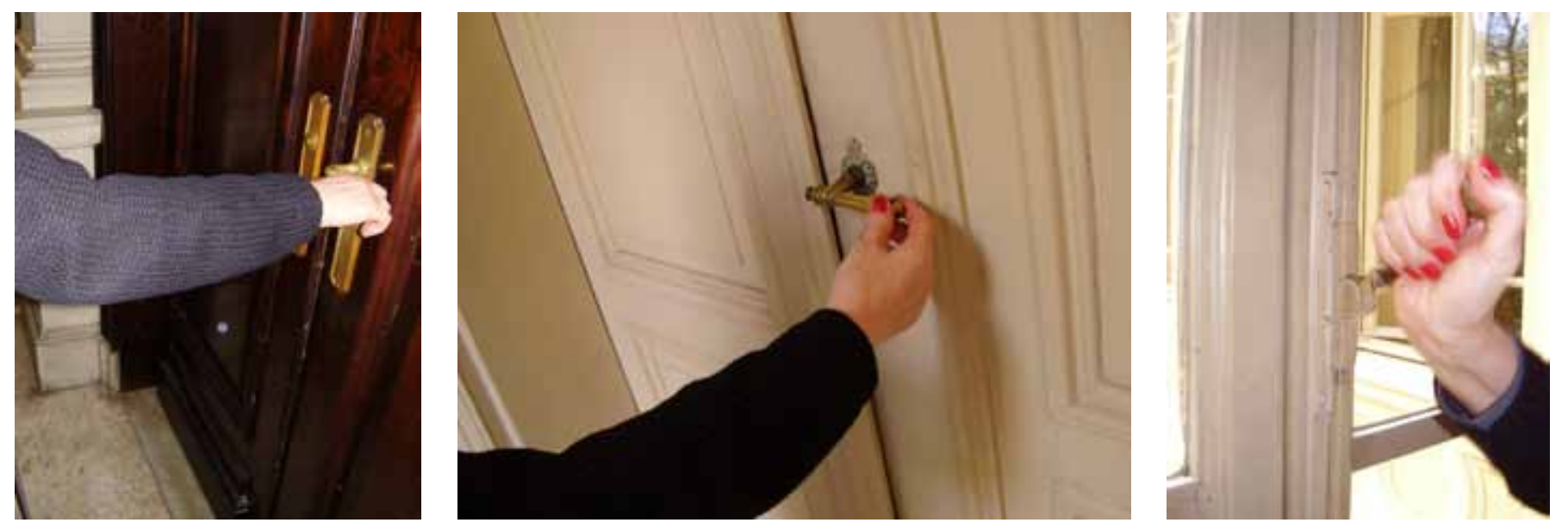

As portas: escuras e claras. A maçaneta da janela é a mesma, tem uma trava enorme que você abaixa.

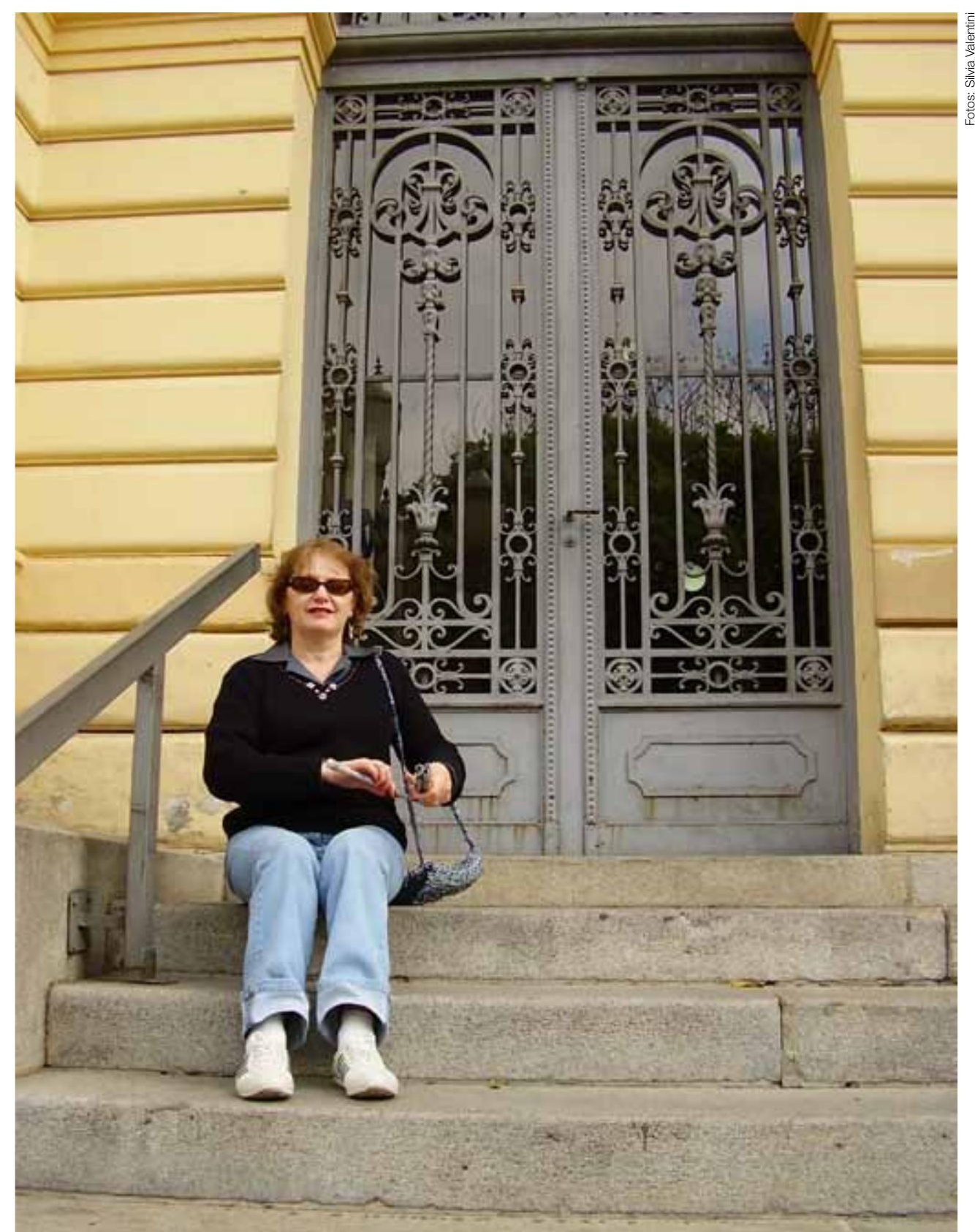

Sandra na entrada do antigo Colégio Caetano de Campos 
Tanto a depressão dos degraus quanto a textura das pastilhas do piso são percebidas pelos pés de Sandra, como se todos os seus sentidos estivessem à disposição da sua memória neste trabalho de reconhecimento. Sente um autêntico prazer na identificação dos elementos e no relato das suas experiências, como um viajante que retorna ao local visitado e presenteia, com a sua própria experiência, quem a está ouvindo ${ }^{4}$.

Do mesmo modo, Juliana viaja no tempo reconhecendo como seu o espaço da casa da infância e rompe os limites da deficiência visual para descrever os detalhes vívidos. A casa dos avós tem cheiro, ritmo, exposição, isolamento. A casa respira.

Eu posso me lembrar da mesa da cozinha, do ambiente, alguma coisa do chão, sei lá, mas eu também vou me lembrar de coisas que eu vivi nela (na cozinha), do cheiro da comida, do cheiro que ela tem, das lembranças que ela me traz, é uma coisa que se mistura, lembranças, com ambiente, com coisas... se chama sinestésico? Mas não sentir só com o tato, sabe, sentir assim com o sentimento...sentir...sentir! Memórias! Se eu pudesse desenhar a casa, eu colocaria cada coisa no seu lugar.

Bachelard elucida que na memória, a casa cresce, estende-se e "para habitá-la é preciso maior elasticidade de devaneio”. E cita o poeta grego Georges Spyridaki: ${ }^{5}$

Minha casa é diáfana, mas não é de vidro. Teria antes a constituição do vapor. Suas paredes condensam-se e se expandem segundo o meu desejo. Por vezes aperto-as em torno de mim, como uma armadura de isolamento... Mas, às vezes, deixo as paredes de minha casa se expandirem no espaço que lhes é próprio, que é a extensibilidade infinita. (BACHELARD, 1993, p. 66)

O corpo de Juliana percebe e guarda a memória do espaço, dos odores, das reuniōes em família, do afeto do avô. Bosi ${ }^{6}$ lembra "que a memória parte do presente, de um presente ávido pelo passado", cuja percepção "é a apropriação veemente do que nós sabemos que não nos pertence mais”, citando p. Nora ${ }^{7}$.

4 BENJAMIN, Walter. O narrador - Consideraçóes sobre a obra de Nikolai Leskov. Magia e técnica, arte e politica - Ensaios sobre literatura e história da cultura. São Paulo : Brasiliense, 1985

5 SPYRIDAKI, Georges. La Grèce et la poésie moderne, París 1954

"Ma maison est diaphane, mais non pas de verre. Elle serait plutôt de la nature de la vapeur. Ses murs se condensent et se relâchent suivant mon désir. Parfois, je les serre autour de moi, telle une armure d'isolement... mais parfois, je laisse les murs de ma maison s'épanouir dans leur espace propre, qui est l'extensibilité infinie."

6 BOSI, Ecléa. O tempo vivo da memória. Cotia : Atelier Editorial, 2004

$7 \quad$ NORA, Pierre. Les lieux de la mémoire. Paris, Gallimard, 1984, p. XXXII. in BOSI, 2004, p. 20 



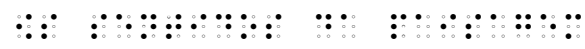

Até hoje eu me lembro do meu avô sentado no fogáo a lenha, nossa, me lembro nitidamente isso e da cozinha antiga, que agora é do consultório, ah, pra mim era linda, encantadora. Tinha um cheiro que não dá pra explicar, como explicar um cheiro, né? Olha, a gente sempre tomava café de tarde, torradinhas, a gente até brigava, quem ia comer primeiro, quem ia terminar primeiro, tinha uma xicrinh a redondinha, um amor, que era a xicrinha dos anóezinhos, todo mundo queria aquela xicrinha, era do meu tio e minha avó guardou ela lá. Claro que agora não tem mais, né? Era na época que a gente era criança. Dai todo mundo queria aquela xicrinha. (Juliana)

No seu entendimento sobre o partilhado convívio com a família, o escritor Autran Dourado 8 descreve características das cozinhas antigas, com chão de fogão de lenha feito de tijolos "a mesa grossa grande muito lavada, as banquetas, os caixotes, o piláo [...] comidas, doces, quitandas, chás caseiros...” E a poetisa Cora Coralina ${ }^{9}$ nos apresenta o encanto das porcelanas antigas em Baixela da China:

Voltando ao prato azul-pombinho que conheci quando menina

e que deixou em mim lembrança imperecivel.

Era um prato sozinho, último remanescente, sobrevivente, sobra mesmo, de uma coleçâo, de um aparelho antigo de noventa e duas peças.

Isso contava com emoção, minha bisavó, que Deus haja.

Era um prato original. Muito grande, fora de tamanho, um tanto oval.

Prato de centro, de antigas mesas senhoriais de familia numerosa.

De fastos de casamentos e dias de batizado.

Pesado. Com duas asas por onde segurar.

Prato de bom-bocado e de máes-bentas. De fios de ovos.

De receita dobrada de grandes pudins, recendendo a cravo, nadando em calda.

Era na verdade um enlevo.

Tinha seus desenhos em miniaturas delicadas:

Todo azul forte, em fundo claro num meio-relevo.

Galhadas de árvores e flores estilizadas.

8 DOURADO, Autran. Uma vida em segredo - Rio de Janeiro : Rocco, 1964

9 CORALINA, Cora. Dos becos de Goiás e histórias mais. Rio de Janeiro : Global Editora, 1983 
Um templo enfeitado de lanternas. Figuras rotundas de entrevês.

Um ilha. Um quiosque rendilhado. Um braço de mar.

Um pagode e um palácio chinês Uma ponte.

Um barco com sua coberta de seda. Pombos sobrevoando

Cuidado com esse prato! É o último de noventa e dois.

\title{
Eu me lembro também que o meu vô descascava as laranjas... ${ }^{10}$
}

Juliana segue com suas memórias:

\begin{abstract}
A minha avó sempre me ensinou muitas coisas quando eu era pequena. Ela me ensinou arrumar a mesa, eu tinha uns quatro anos, ela tinha uma paciência... Dobrar o guardanapinho, pôr uma pontinha para lá, outra para cá, uma paciência, sabe, me ensinou a lavar a louça, ela me deixava fazer as coisas. $E$ até hoje quando vou arrumar a mesa, tenho que colocar primeiro o garfo, depois a faca do lado, parece que se eu botar diferente não fica a mesma coisa.
\end{abstract}

O piso gasto da cozinha conta a história dos passos, das lides domésticas, da alquimia de sabores e perfumes, do som da polenta italiana tostando, estalando na chapa, do cheiro do orégano seco que incitava a fome e hoje surge na lembrança. Arrumar a mesa, dispor os talheres, dobrar perfeitamente os guardanapos significava "eu posso", enquanto que a expectativa da tramela que poderia trancar provocava medo e traduzia-se em "não posso". Para Bachelard (1993, p. 24-25) “[...] a casa é o nosso canto do mundo [...] o nosso primeiro universo. É um verdadeiro cosmos. [...] A vida começa bem, começa fechada, protegida, agasalhada no regaço da casa. [...] Reconfortamo-nos ao reviver lembranças de proteção".

Em Nava ${ }^{11}$ também encontramos referências à casa de sua lembrança:

Esse portão de ferro prateado, eu o abro com as mesmas chaves da memória que serviram ao nosso Machado, a Gérard de Nerval, a Chateaubriand, a Baudelaire, a Proust.

10 Juliana, recordando os perfumes da cozinha da casa da avó.

11 NAVA, Pedro. Baú de ossos: memórias. 4a ed. Rio de Janeiro : José Olympio, 1974 
Todo mundo tem sua madeleine, num cheiro, num gosto, numa cor [...] Essa retomada, a percepção desse processo de utilização da lembrança [...] tem algo da violência e da subtaneidade de uma explosão, mas é justamente o seu contrário porque concentra por precipitação e suscita crioscopicamente o passado diluído. [...] Cheiro de moringa nova, gosto de sua água, apito de fábrica cortando as madrugadas irremediáveis. Perfume de sumo de laranja no frio ácido das noites de junho. [...] Quem entrava dava num pátio cimentado em frente à casa [...] o cadeado e a corrente impediam-me de sair e misturar-me à molecada. Eu olhava, trepado na mureta de pedra, seguro ao gradil, como a balaústres de bonde fabuloso que me levasse. (NAVA, 1974, p. 303)

Juliana segue no relato de suas emoções:

Tinha fogão de gás, mas tinha fogão de lenha. Ela usava os dois. Meu vô ficava muito perto do fogo, porque ele tinha frio; ele gostava de ficar lá, o fogo é uma companhia, né? Aliás, tem um texto do Rubem Alves que fala exatamente sobre o fogão de lenha, nossa, tão lindo, encantador. Eu me lembro também que o meu vô descascava as laranjas e pendurava as cascas no ferrinho do fogão. Não sei pra quê, pra secar, pra fazer alguma coisa com elas.

Explico que as cascas secas servem para acender o fogo. Quando acende estala, a casca tem um óleo essencial, exala perfume.

É pra isso? Eu me lembro disso e minha mãe tinha um fogão desses antigos de ferro, sabe aqueles com florzinha na frente? É lindo, lindissimo, encantador.

Em sua narrativa Juliana indica as singularidades de sua casa, as escolhas de sua mãe que valorizavam o interior da residência. Uma descrição que sugere acolhimento, proteção, amorosidade.

Aquelas chapas grandes, é bom para fazer polenta; minha mäe faz até hoje, mas não no fogáo de lenha. Brustolada, que é italiano, torrada, depois de pronta, durinha, corta e bota na chapa pra brustolar. E com queijo em cima, e orégano. As comidas da minha avó, pudim, muita massa de família italiana. Hoje minha avó não faz tanta comida. Eu me lembro da massa dela, nossa, que boa. Gosto de cozinhar, mexer na 
massa do nhoque. Não tenho facilidade com as medidas, sei fazer coisas simples. Do lado de fora tinha um pátio imenso, ainda tem, tinha muitas árvores, a gente brincava de se esconder, eu falava que lá era uma floresta. E grama, bastante grama. Minha avó pedia pra eu recolher as folhas, ela me dava uma caixa de papelão, eu ia lá e botava tudo dentro da caixinha. Eu adorava ficar na minha avó, até hoje eu gosto. E nada a impedia de deixar fazer.

O gramado era palco de jogos infantis, cabra-cega com os primos, com direito à alternância da deficiência. Na falta de companhia, havia o jogo solitário de "resta um" que as folhas secas das árvores da "floresta" propiciavam. O mesmo espaço podia combinar convívio e solidáo. Bachelard (1993, p. 29) reflete sobre a maneira indelével como esses espaços das nossas solidôes passadas residem em nós; são espaços constitutivos, voltam nos sonhos e na memória, têm o mesmo valor da concha que acolhe.
A minha mäe também deixou fazer muita coisa, mas é diferente, é outra coisa. Avó e mãe são diferentes, é outra relação, é diferente. Quando eu era criança eu vestia as roupas da minha vó e os sapatos de salto da minha máe e ia para a vizinha comer balinhas de peixinho. Lembra daqueles guarda-chuvinhas de chocolate? Eu tive uma decepção. Eu fui comprar e é uma porcaria, tem gosto de sabão.

Rimos. Juliana encadeia e compóe, à vontade e com liberdade, os momentos vividos no passado (BOSI 2003, p. 55). Organiza o relato a seu modo, lembra o avô. Respeito os caminhos da narrativa e da emoção.
Ah, tem uma coisa: quando eu era pequena não tinha relógio em braille, nem relógio que fala, né? Então tinha um relógio que batia as horas: blém, blém. Quando ele (o avô) acordava, os quartos eram em cima, a primeira coisa que ele fazia era dar corda no relógio. Eu contava as batidas para saber as horas e ele gostava disso, de ouvir eu contando as horas. Entäo minha avó falou que esse relógio ia ficar para mim, e ele está aqui em casa. Ele é um relógio de corda, lindíssimo, antigo, quadrado, tem um vidro por fora, ai tu abre o vidro e dentro tem o ponteiro e o pêndulo. Ele é de parede.

Conversamos sobre relógios antigos. Em seu relato, Juliana me faz lembrar Violette Morin, citada por Bosi (2003, p. 26), ao descrever objetos biográficos, que "envelhecem com o possuidor e se incorporam à sua vida: o relógio da família, o álbum de fotografias, a medalha do esportista [...] as coisas que envelhecem conosco nos dâo a pacífica sensação de continuidade". 
Que pena que eu não posso acertar ele. Eu tenho medo de mexer, eu nunca parei pra ver, ele não é em braille. Não sei se dá pra mexer nos ponteiros, como o de braille, que é feito pra mexer. Mas ainda vou mexer. Ele tem uma chavezinha que encaixa e dai dá corda. Ele bate uma vez para meia hora e a hora inteira. Dá pra ouvir do meu quarto, geralmente minha mãe é que dá corda.

Bachelard reflete sobre a filosofia da literatura e a capacidade que temos para imaginar o nosso próprio quarto, ao lermos sobre um quarto qualquer:

Assim, rapidamente, desde as primeiras palavras, na primeira abertura poética, o leitor que lê 'um quarto' interrompe a sua leitura e começa a pensar em algum aposento antigo. [...] Os valores de intimidade são tâo absorventes que o leitor já não lê o seu quarto: revê o dele. Foi já escutar as lembranças de um pai, de uma avó, de uma mãe, [...]. (BACHELARD, 1993, p. 33)

Eis como Juliana descreve então o seu quarto:

Por exemplo, o meu quarto: tem a cama, o bidê (criado-mudo), o guarda-roupas, a cômoda, um cabide de madeira e o móvel do computador. E um tapetinho.

Pergunto como imagina esse cenário.

Deixa eu parar para pensar, nossa, nunca pensei sobre isso, se os objetos estão o tempo todo ali, no meu entorno. Acho que só um ou dois de cada vez, não tenho certeza, é quase certo.

E como é o resto da casa?

Deixa eu imaginar a cozinha...não, não consigo, acho que só a mesa. Depois vou me lembrando que tem a geladeira, o fogão...nossa, é muito doido...vocês imaginam tudo? Ese agora você resolve mudar os móveis da cozinha do lugar? Você consegue imaginar eles em outro lugar? 


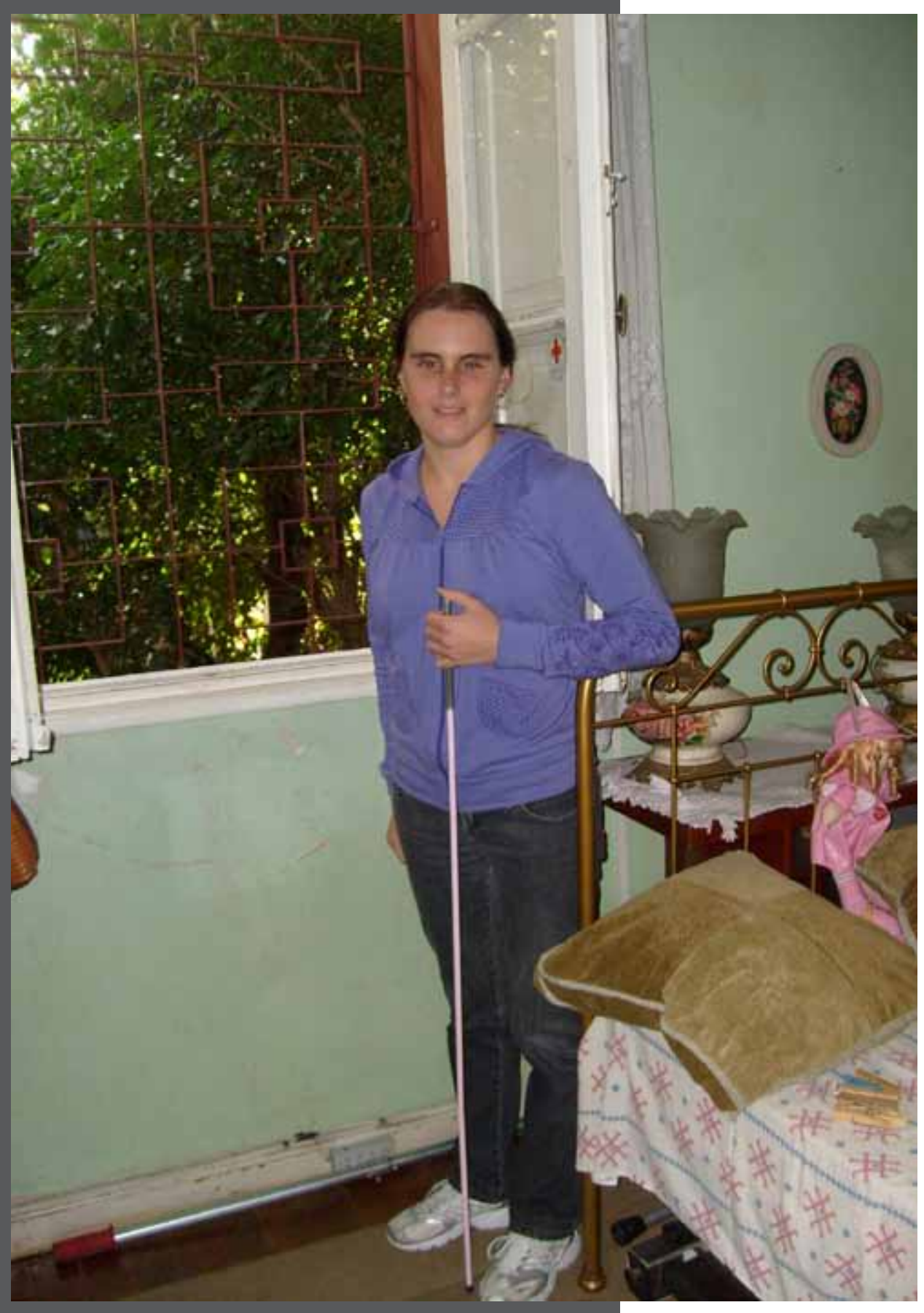

O meu quarto tem a cama, o guarda-roupas, a cômoda um cabide de madeira... 
Comento que ela poderia perceber o conjunto em uma maquete, por exemplo, uma maquete com todos os móveis do quarto, de maneira que possibilite a compreensão do conjunto.

Mas não precisa, isso não faz parte da minha vivência, eu tenho a planta do meu quarto na minha cabeça, não preciso disso. Na maquete eu também não vou sentir tudo de uma vez, eu nunca vou conseguir sentir tudo de uma vez e pra quê ver tudo de uma vez? Pra nada, porque tu conhece igual, é um outro tipo de conhecer.

Merleau-Ponty aponta que talvez ainda não tenhamos percebido a verdadeira função do juízo na percepção.

Há uma percepção empírica ou segunda, aquela que exercemos a cada instante, que nos mascara este fenômeno fundamental porque ela é inteiramente plena de aquisições antigas e opera, por assim dizer, na superfície do ser. Quando olho rapidamente os objetos que me circundam para me situar e orientar-me entre eles, mal tenho acesso ao aspecto instantâneo do mundo, identifico aqui a porta, ali a janela, mais adiante a minha mesa, que são apenas os suportes e os guias de uma intenção prática orientada em outra direção e que agora só me são dados como significações. Mas, quando contemplo um objeto com a única preocupação de vê-lo existir e desdobrar diante de mim as suas riquezas, então ele deixa de ser uma alusão a um tipo geral e eu me apercebo de que cada percepção, e não apenas aquela dos espetáculos que descubro pela primeira vez, recomeça por sua própria conta o nascimento da inteligência e tem algo de uma invenção genial: para que eu reconheça a árvore como uma árvore, é preciso que, abaixo desta significaçáo adquirida, o arranjo momentâneo do espetáculo sensível recomece, como no primeiro dia do mundo vegetal, a desenhar a idéia individual desta árvore. (MERLEAU-PONTY, 1994, p. 74-75)

Nossa percepção chega a objetos, e o objeto, uma vez constituído, aparece como a razão de todas as experiências que dele tivemos ou dele poderíamos ter. Por exemplo, vejo a casa vizinha sob um certo ângulo, ela seria vista de outra maneira da margem direita do Sena, de outra maneira do interior, de outra maneira ainda de um aviáo [...] (MERLEAU-PONTY, 1994, p. 103) 
[...] olhar um objeto é vir habitá-lo e dali apreender todas as coisas segundo a face que elas voltam para ele. Mas, na medida em que também as vejo, elas permanecem moradas abertas ao meu olhar e, situado virtualmente nelas, percebo sob diferentes ângulos o objeto central de minha visão atual. Assim, cada objeto é o espelho de todos os outros. Quando olho o abajur posto em minha mesa, eu lhe atribuo não apenas as qualidades visíveis a partir de meu lugar, mas ainda aquelas que a lareira, as paredes, a mesa podem "ver", o verso de meu abajur é apenas a face que ele "mostra" à lareira. [...] Qualquer visão de um objeto por mim reitera-se instantaneamente entre todos os objetos do mundo que são apreendidos como coexistentes, porque cada um deles é tudo aquilo que os outros "vêem" dele. (MERLEAU-PONTY, 1994, p. 105).

Esta colocação de Merleau-Ponty me remete ao depoimento de Juliana e sua reflexão sobre a capacidade que videntes têm de ver o cenário completo, da maneira como se nos apresenta, com mobiliário, peças de decoração, utilitários, pessoas. Para a jovem, cega congênita, tal possibilidade é excessivamente cansativa e confusa, já que sua imaginaçáo lhe permite pensar apenas um objeto de cada vez, conforme os toca, sem conseguir compor o cenário no conjunto de peças como ele se apresenta. Sandra, no entanto, tem melhor entendimento do espaço, talvez por guardar referências da infância, de quando ainda enxergava. Este é um dos exemplos que ratificam que a deficiência visual tem características próprias e diversas para cada pessoa.

$\mathrm{O}$ conceito de percepção do todo poderia ser apresentado às crianças cegas congênitas, na infância, com o auxilio de maquetes e peças tridimensionais? Montagu reflete sobre a percepção tátil na infância e lembra Maria Montessori, quando em 1907 mostrou que as crianças que podiam tocar as letras aprendiam-nas mais rapidamente do que as que apenas as observavam:

Tem-se sugerido recentemente que se crianças cegas de nascença puderem sentir 'visualizaçôes', então, talvez, seja um processo natural a transferência da sensação de um padrão para o reconhecimento de sua imagem visual. Infelizmente, os fatos não apóiam essa sugestão: para os cegos de nascença as coisas não têm distância espacial e por isso eles são incapazes de julgar a distância. (MONTAGU, 1986, p. 185)

A experiência com as ilustraçóes editadas no Boletim Ponto a Ponto mostra que muitas das pessoas cegas aprendem a apreciar as ilustraçóes, principalmente as mais simples, que apresentam menor número de detalhes. 

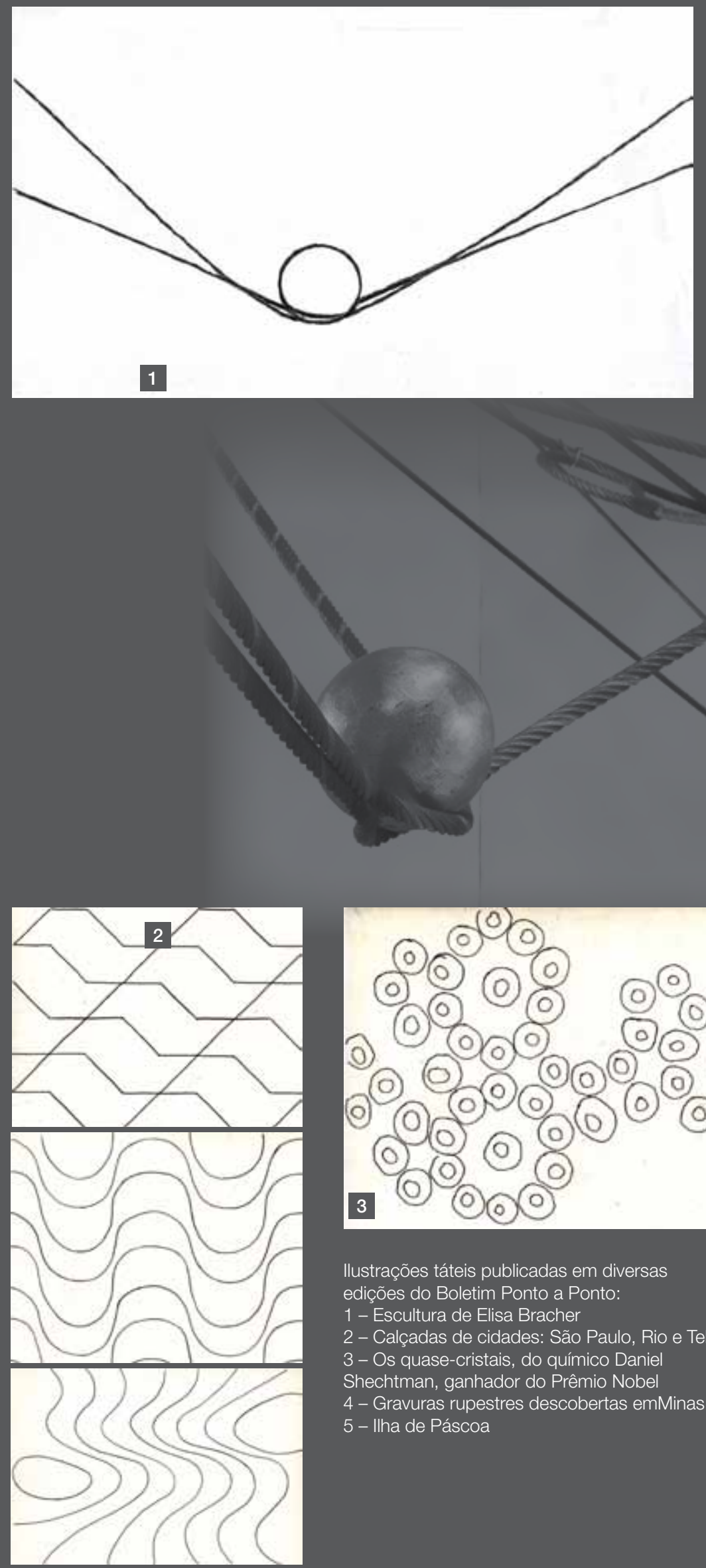
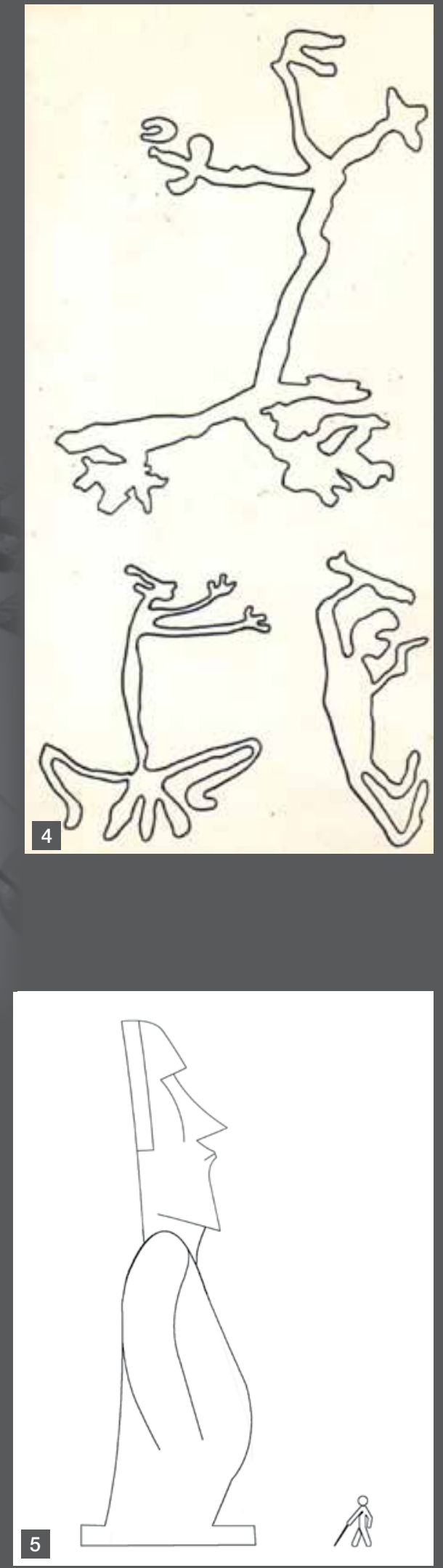
Sobre a percepção espacial ser resultado de nossa experiência, e assim não existir para os cegos, apoio-me no argumento de Révész, quando reflete que a investigação do espaço propóe uma questão universal de importante significado e extensão quase ilimitada. O autor lembra Kant e a reflexão do filósofo sobre a idéia do inatismo do espaço, apontando que, se interpretamos a qualidade inata do espaço de maneira a pensá-lo inerente, significa que o caráter espacial e a ordem das coisas são inerentes, ao contrário da idéia de experiência do espaço; e entáo a contradiçáo entre a teoria de espaço de Kant e a dos matemáticos, desaparece. Ninguém manteria então que a espacialidade das coisas é o resultado da nossa experiência. Em outras palavras, ninguém diria que a qualidade, o caráter da nossa percepção sensória é tal que os objetos são colocados externamente ao nosso corpo, de maneira a experimentarmos uma ordem específica e uma relação precisa entre as coisas e nós. (1937, p. 429-444, tradução minha)

\section{Espaços recortados}

Merleau-Ponty discorre sobre o domínio que temos dos nossos espaços e a relaçáo dos objetos que o compóem:

Quando me desloco em minha casa, sei imediatamente e sem nenhum discurso que caminhar para o banheiro significa passar perto do quarto, que olhar a janela significa ter a lareira à minha esquerda e, nesse pequeno mundo, cada gesto, cada percepçáo, situa-se imediatamente em relação a mil coordenadas virtuais. Quando converso com um amigo, conheço bem cada uma de suas expressōes e cada uma das minhas incluem, além daquilo que elas significam para todo o mundo, uma multidão de referências às principais dimensóes de seu caráter e do meu, sem que precisemos evocar nossas conversaçôes precedentes. (MERLEAU-PONTY, 1994, p. 182)

Merleau-Ponty reflete sobre as percepçóes e conceitos que organizam nossas atitudes como videntes. Nesse sentido, pessoas cegas atuam de outra maneira, cegos congênitos têm outro panorama. Como será o "panorama mental" das pessoas com deficiência visual? Quando passam por uma banca de jornal, qual é a referência que têm? No que difere passar por um carro estacionado, ou algo menor?

"Meu apartamento não é para mim uma série de imagens fortemente associadas", revela o filósofo, "ele só permanece como domínio familiar em torno de mim se ainda tenho suas distâncias e 


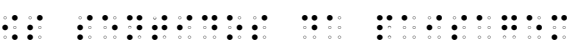

suas direçóes 'nas mãos' ou 'nas pernas', e se uma multidão de fios intencionais parte do meu corpo em direção a ele”. (MERLEAU-PONTY, 1994, p. 182)

Essa figuração de fios partindo do corpo para alcançar os espaços, cria uma tensão poética e sugere uma pesquisa de percursos feitos dentro da casa de pessoas cegas, como as açóes de percorrer e decorar caminhos, assim como também a disposição do mobiliário. Quando dormia na casa da avó, a pequena Juliana ficava, do seu quarto, a contar as batidas do relógio carrilhão que fazia parte da decoração da sala. Sua imaginação perfazia o caminho, dominava o espaço, rompia as distâncias, inscrevia suas referências de infância e seus primeiros entendimentos.

A descrição do entendimento dos espaços e distâncias e dos hábitos e esquemas corporais, é feita por Merleau-Ponty, citando Head e Grunbaum, que aponta a maneira como a máo alcança o chapéu que está na cabeça. Do mesmo modo como conseguimos estacionar o carro em uma vaga na rua. O carro é uma "potência volumosa” e a vaga é uma "potência constrangedora” para o meu carro, assim como a porta do Metrô é uma "potência constrangedora" para o meu corpo. A bengala de uma pessoa cega explora e percebe objetos, "sua extremidade transformou-se em zona sensível". "Habituar-se a um chapéu, a um automóvel ou a uma bengala é instalar-se neles ou, inversamente, fazê-los participar do caráter volumoso do nosso corpo próprio" (MERLEAU-PONTY, 1994, p. 199).

$\mathrm{Na}$ aquisição do hábito, é o corpo que compreende e, da mesma maneira como os nossos passos sobem escadas, as pessoas cegas memorizam caminhos. Caminhos que são rastreados com a bengala, que para a pessoa cega deixou de ser um objeto adquirido e se transformou em um prolongamento da mão, aumentando "a amplitude e o raio de ação do tocar". O corpo compreende, ensina Merleau-Ponty. "Compreender é experimentar o acordo entre aquilo que visamos e aquilo que é dado, entre a intenção e a efetuação - e o corpo é nosso ancoradouro em um mundo” (MERLEAU-PONTY, 1994, p. 200).

Tendo em mente a colocação do autor de que nosso campo perceptivo é feito de coisas e de vazios entre as coisas, pedi a Sandra que me descrevesse o seu quarto:

Meu quarto é um quadrado e entrando, à minha esquerda, tem um armário embutido, de três portas; se eu der mais três passos para frente eu já vou encontrar os pés da cama, entâo aí eu tenho um espaço grande, acho que de mais de um metro, entre a cama e a parede do lado direito, forma como um corredor. Ai, eu seguindo em frente por esse vão, eu vou dar na janela do quarto que é a parede toda, de cima abaixo. E dai estando de frente para a janela, à minha esquerda já terminou a cama e eu indo então para a 
esquerda, para a lateral da cama, eu vou ter a mesinha de cabeceira, à esquerda, e à direita a penteadeira, a banqueta, o espelho na parede, que eu não vejo, mas eu sei que ele está ali.

Pergunto como ela calcula esse espaço vazio de um lado até o outro, se ela já tem o hábito ou se vai experimentando, até chegar de um lugar ao outro.

Não. Já tenho o condicionamento, se por um acaso mudar dez centimetros de lugar eu provavelmente já vou esbarrar, se a cama mudar dez centimetros para um lado ou para outro. Eu tenho noção perfeita do tanto que eu ando para chegar até lá.

Pergunto se usa as paredes como referência, usando o exercício de orientação e mobilidade.

Não, eu tenho a noção do todo, não preciso, por exemplo, passar a mão para sentir em que parede eu estou. Próxima de que parede. Só se girar bastante e depois parar (ri) e agora, onde você está?

Para Merleau-Ponty, a percepção não pode ser considerada através de seus resultados, das associaçóes. Ela é um fenômeno, precede a si mesma. Ao refletir sobre a espacialidade do corpo, o autor observa:

Se meu braço está posto sobre a mesa, eu nunca pensaria em dizer que ele está ao lado do cinzeiro, do mesmo modo que o cinzeiro está ao lado do telefone. Se fico em pé diante de minha escrivaninha e nela me apóio com as duas mãos, apenas minhas mãos estáo acentuadas e todo o meu corpo vagueia atrás delas, como uma calda de cometa. Não é que eu ignore a localização dos meus ombros, ou dos meus rins, mas ela só está envolvida nas minhas mãos e toda a minha postura se lê por assim dizer no apoio que elas têm na mesa. (MERLEAU-PONTY, 1994, p. 146)

Pergunto para Sandra se em sua casa ela reconhece os objetos que estáo em torno de si, quando está sentada em frente a uma mesa, se tem consciência de tudo o que tem sobre aquela mesa.

Tenho a noção de que a mesa da sala, por exemplo, fica no centro da sala e eu sou capaz de olhar para lá e ver que tem uma toalha branca, ver o cachepô com as plantas, tudo direitinho, mas eu náo estou vendo nada, só sei o que tem. 
Sobre a percepção sinestésica, Merleau-Ponty diz que se não a percebemos é por interferência do saber científico, que desloca a experiência e porque desaprendemos de ver, ouvir, e sentir. Quando ouvimos a descrição que Juliana faz da cozinha de sua casa percebemos a riqueza da percepção. Os sentidos comunicam-se entre si, diz o autor, e abrem-se à estrutura da coisa. "Quando um vidro se quebra, o som é trazido pelo vidro visível. No movimento de um galho que o pássaro acaba de deixar lemos sua flexibilidade". O autor destaca como os sentidos traduzem-se uns aos outros sem precisar de intérprete, compreendem-se uns aos outros sem precisar passar pela ideia (MERLEAU-PONTY, 1994, p. 315).

Merleau-Ponty aponta que o corpo é a própria atualidade do fenômeno de expressão: "nele a experiência visual e a experiência auditiva, por exemplo, são pregnantes uma da outra, e seu valor expressivo funda a unidade interpretativa do mundo percebido". O nosso corpo, diz o autor, é a textura comum de todos os objetos e o instrumento da nossa compreensão. A palavra "quente" induz a uma experiência de calor. A palavra "duro" suscita rigidez nas costas e no pescoço. Não sou eu que toco, diz ele, é o meu corpo. Podemos nos unir ao fenômeno e nos comunicar com ele quando nossa mão reconhece o duro ou o mole, quando o nosso olhar reconhece a luz. É como se o exterior nos invadisse e nós o acolhêssemos em uma espécie de simbiose.

Podemos perceber os fenômenos porque o nosso corpo é feito de sistemas de potências perceptivas. Quando Merleau-Ponty coloca que "as propriedades sensoriais de uma coisa constituem em conjunto uma mesma coisa assim como meu olhar, meu tato e todos os meus outros sentidos são em conjunto as potências de um mesmo corpo integradas em uma só ação", é como se fizesse a introdução da teoria de Gibson, sobre os sistemas perceptivos.

Daniel é engenheiro e perdeu a visão há aproximadamente três anos. Casado, duas filhas, há pouco mais de um ano recebeu o título de Mestre em Tecnologia Nuclear. Aprendeu a ler braille com surpreendente rapidez e tornou-se assíduo frequentador da Biblioteca Braille do Centro Cultural São Paulo. Conta que agora lê muito mais do que quando enxergava e podia ler livros impressos em tinta. Enviou-me depoimentos em braille e por e-mail. Por telefone e pessoalmente, relatou o seu cotidiano com a família:

No jantar sou o descascador "oficial" das frutas: descasco as laranjas de todos, o meláo da Laura, o pêssego da Luiza, a minha manga etc. Sempre preparo o suco de maracujá, que é a minha especialidade. Normalmente também lavo os pratos, retiro o lixo normal e faço a separação dos materiais que vão para o lixo reciclável. Na faxina da casa encarrego-me da 
limpeza dos banheiros. Como é um espaço retangular relativamente pequeno, não tenho muita dificuldade. Divido os pisos e azulejos em pequenas áreas para ter certeza que esfreguei todos. Nos outros aposentos, passo o aspirador, que considero uma tarefa mais complicada, por tratar-se de áreas maiores. Também tento dividir em pequenas regióes para alcançar todas. Utilizo o fogão apenas para esquentar água para fazer café. Quando necessário esquento um prato preparado pela Nice no micro ondas. Para operá-lo colei um "rotex" em "braille" nas teclas "5", "tempo" e "ligar". É o suficiente! Tenho ainda a memória visual do espaço da casa e da disposição dos móveis, o que me permite visualizar todos os ambientes, como se estivesse enxergando. Utilizo esta memória visual para deslocar-me sem esbarrar nos obstáculos. Só tenho muita dificuldade para andar no quarto das meninas que é um verdadeiro campo minado!

Na subdivisão que Daniel faz para a limpeza eficiente dos azulejos, transparece a metodologia do engenheiro. Mas, ao falar da intensidade das sensaçóes, encontramos o poeta:

Das coisas agradáveis que existem aqui em casa e que eu agora percebo com maior intensidade sáo o frescor do vento e o calor do sol que entram pela janela do meu quarto. Também se acentuou a percepção da presença dos pássaros que diariamente visitam nosso pequeno jardim. Caminhar descalço pela casa é outra situação que passou a ser mais agradável. Agora é mais perceptivel o frio gostoso dos pisos de cerâmica e a rugosidade da escada mal acabada (sinto apenas o concreto e náo enxergo a falta de acabamento que a tornaria visualmente mais bonita).

\section{Eu estava lá, ela viu a minha pessoa, gostou ${ }^{12}$}

Rubens, 37 anos, era ajudante de pedreiro quando perdeu a visão. Mora com a mulher, Solange, no Itaim Paulista, em casa alugada, aonde chega de trem. Foi alfabetizado em braille, antes não tinha leitura.

Conheci minha mulher na linha do bloqueio do metrô, tinha marcado com um colega dela que eu conheci numa sala de bate-papo por telefone. A gente começou a fazer 


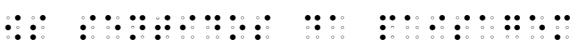

amizade e ele não podia me buscar ainda, pois ia tomar banho, ai ela estava lá e foi me buscar, eu liguei para ele e ele falou que a colega dele ia me buscar. Ai eu estava lá, ela viu a minha pessoa, gostou da minha pessoa, e ai a gente começou a fazer amizade. Nem chegamos a fazer amizade, ai nós fizemos um mês de amizade e começamos a se gostar e quando foi no dia 13 de agosto a gente começou a namorar e depois de um mês a gente já estava morando juntos. Agora a gente já está com dois anos e três meses que está casado. Quem cozinha é ela, ou eu, eu não sabia, sabe como é, quando a gente está na casa da mäe... Ontem mesmo ela saiu, eu vim aqui e pensei:

- Puxa vida, ainda tenho que chegar em casa, passar no mercado e fazer arroz, que eu estava com fome. Cheguei em casa, liguei o rádio, fiquei ouvindo um sonzinho que eu gosto, à noite e ai já fui pegando arroz, me ajeitando para preparar o arroz. O café eu faço em um bule normal, porque o café Pilāo rende, ele é forte, e eu faço um bule. Conforme eu faço um pouco a mais eu já tenho uma leiteirinha, não me lembro como é o modelo dela. Eu reparto, pra não ir muito açúcar, reparto, não adoço tudo. Reparto. Quem mais faz café em casa sou eu, ela faz também. Mas às vezes ela está dormindo, chegou um pouco tarde para resolver as coisinhas dela, então eu já faço. O arroz foi ela que me ensinou. Só não cozinho feijão porque é ela que cozinha; agora, refogar o feijāo eu sei. Aprendi a limpar a casa, normal. Ah, a vida de casado mudou bastante. Quando a gente é solteiro, a gente chega em casa e está tudo feito. Agora, quando você casa, a vida muda. A situação muda, fica faltando uma coisa, outra, fim do mês, tem que estar arrumando com alguém pra repor, tem que ficar consultando o calendário para vencer o gás, caramba. Quando tá solteiro, tá nem aí, entrega o dinheiro na mão da mãe, ela vai lá compra o gás, acabou.

Rubens e Solange eram estudantes, trabalhavam, mas perderam o emprego e interromperam os estudos. Juliana, no entanto, estava para terminar o seu curso, quando descreveu o ambiente da faculdade:

A minha mãe me leva de carro lá na faculdade, mas lá é bem facinho de andar. Letras tá num bloco só, o Bloco J e é bem fácil da gente andar, tem corredores, é fechadinho, sabe? A minha mãe me leva e me diz: tu estás em tal lugar, e agora vai para a esquerda exatamente a referência para eu saber para eu depois continuar, sabe? É gostoso lá, é um bloco bem aconchegante. Ele é novo, então ele tem cheirinho de novo, eu adoro aquele cheirinho, cheirinho de madeira, é bem bom. É bem acessivel 
porque agora tem essa história de rampa e ele é bonito, embora eu não saiba como ele é fisicamente. Não é que eu não saiba, eu sei as coisas que eu consigo ver. Mas o cháo dele é lisinho, sabe, na ponta dos degraus tem aquele antiderrapante, eu gosto de sentir essas coisinhas, é bem gostoso de caminhar lá. Quando eu saio do carro, eu caminho um pouco ainda num lugar aberto, que tem umas cadeirinhas para as pessoas sentarem e logo eu já entro, tem a rampinha e logo eu já entro no bloco. O espaço das cadeirinhas é aberto, fora do bloco, tem o ar puro, apesar de que já não é tão puro porque tem gente que fuma, é horrivel, não gosto; tem ainda cheiro de árvore, porque na faculdade tem ainda muitas árvores, ai é aberto, é friozinho, é fresquinho porque é de noite, eu estudo de noite.

De dia, quando não tem muito aluno é que dá pra sentir a natureza, tem os passarinhos cantando, se ouve mais passarinhos, som de água não tem, canto de pássaros bem diferentes. Dai, eu entro no bloco, não dá pra se perder nele, sabe, ele é bem acessivel, como eu te disse ele é bem fechadinho; embora ele tenha vidros que dê pra tu enxergar pra fora ele reflete o sol sabe, porque tem a claridade que fica pra dentro, ele não é escuro. Mas ele não é assim aberto que tu te percas lá dentro, que nem aquelas coisas que não tem diferença nenhuma, ele é bem retinho assim com corredores, escadas. Eu vou mais pela parede. Também agora na escada, como tem que descer só dois lances, eu nem coloco a mão no corrimão, às vezes sim, às vezes não...

Dentro é mais quentinho, esse bloco é bem quentinho. Não circula tanto o ar quanto lá fora, claro, lá fora o ar circula mais fresquinho, você sente o cheiro de algumas árvores; lá dentro não, tu sentes o cheiro de cigarro e da madeira e outros cheiros das pessoas, perfumes, e outros cheiros.

O cigarro me irrita profundamente, odeio, é horrivel, e lá na faculdade fumam nos corredores, na janela, lá fora. Barulho também não gosto, barulho de moto, de carro, indo e vindo toda hora, é uma coisa que irrita qualquer pessoa, né? A mim também irrita. Perfumes fortes também irritam; tudo tem que ser discreto, assim, meio termo, assim como eu também não gostaria de passar um perfume forte, depende, tem uns que gostam, mas eu também fico pensando no que as pessoas podem sentir, sabe?

Eis como Sandra descreve o tempo vivido no seu colégio e explica a apreensão do espaço: 


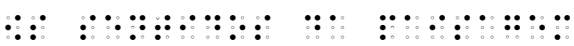

Tinha independência total, não usava bengala, mas o colégio era muito claro e amplo e as professoras e funcionários tinham um cuidado com o deficiente visual, não extremo, mas tinha inspetora de alunos nas salas e ela vivia nos corredores, limpando, cuidando dos toaletes. Quando ela via um dos deficientes circulando, ficava de olho e se ela via que nós iamos esbarrar nas janelas, a gente nunca vinha muito perto das janelas, mas se a gente fosse esbarrar, ela avisava, eles tinham um cuidado muito grande. Eu falava das janelas, o peitoril é de mármore e continua o mesmo. Subindo a escada aqui no $1^{\circ}$ andar, à nossa esquerda tinha a sala braille, que era uma sala de apoio. A gente era alfabetizada ali e depois ia para as classes normais comuns, tinha uma professora de manhã e outra à tarde e a gente levava as provas, para serem transcritas do braille para tinta ou vice-versa e ali era uma sala assim, bem descontraida, aos sábados a gente jogava dominó porque nós tínhamos poucas aulas e ai era o único dia da semana que juntava os meninos com as meninas, era no sábado de manhã, que era o período dos meninos, as meninas estudavam sempre à tarde. Então jogávamos dominó, a gente tinha um amigo que tocava violão e a gente cantava, no sábado era higiene mental, embora a gente viesse para a aula, era menos importante.

Sandra valoriza as texturas e se lembra até mesmo das emendas do piso. E também da escada, tão usada, assim como do vitral cujo desenho, mesmo sem nunca ter visto, sabia ter predominância do azul.

\section{Vamos descer?}

No térreo, debaixo da escada, encontramos a porta do auditório. A maçaneta da porta é a mesma, olha a largura da porta! $\mathrm{O}$ abrir e fechar de portas e janelas remete a Lucrécio, que reflete sobre a natureza das coisas, como se a descoberta do mundo fosse um exercício de destrancar portas.

Lá dentro, mais emoçôes: cheiro de piso de madeira encerado. O sol não alcança o auditório mas, mesmo assim, sentimos o perfume da madeira encerada. Ackerman (1992, p. 34) informa como o sol potencializa alguns odores. Quando sentimos cheiro de alguma coisa, 40 extremidades nervosas são atingidas, lembra a autora.

Pergunto para Sandra o que sente quando pensa no prédio, no todo.

Eu vejo, eu lembro da imagem que eu tinha daquele pouco que eu enxergava. Eu lembro que além do térreo tinha mais dois ou três andares. E náo saberia te dizer se 
era um retângulo ou um quadrado. E as laterais, o telhado, uma linha reta, não me lembro de ver nada arredondado. O beiral, ou moldura, formava como uns degraus na parede de fora a fora. Os janelóes lindos, que eu sempre admirei muito essas janelas e aqui nessa entrada eu me lembro de ver as duas portas e janelas laterais que estavam sempre fechadas e a do meio sempre aberta uma folha, só em dia de festa ou colação de grau eles abriam as duas, caso contrário ficava só uma. Então, eu vejo desse jeito.

As portas têm dois lados, o de dentro e o de fora. Para quem vem de fora, há a perspectiva do abrigo, para quem sai, o espaço escancarado. O lado de dentro náo existe sem o lado de fora. Os cheiros de dentro, reservados, íntimos, sussurram. Lá fora, o vento não pede permissão, invade, traz notícias de longe, esculpe as formas, mistura tudo, cheiro de gente, de grama cortada, da calçada lavada. Sensaçóes do presente e do passado. Sandra completa:

(...) dá uma saudade de voltar e dar mais valor ao que a gente viveu aqui, ter anotado, ter registrado, gravado, feito qualquer coisa que deixasse mais uma lembrança, mas na época a gente não tinha assim essa preocupação. 


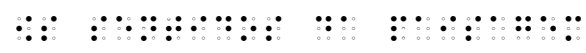

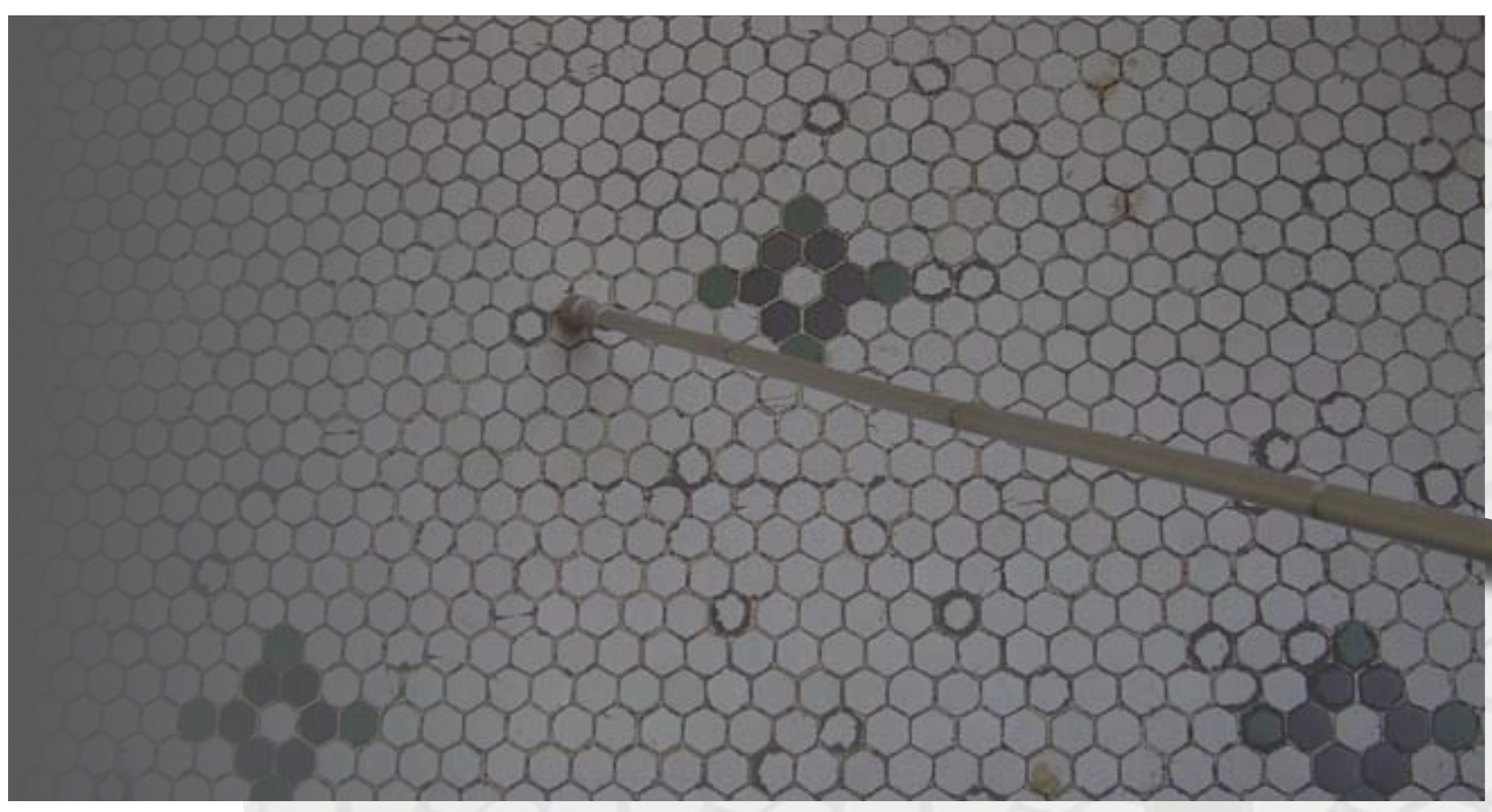





\section{Os SENTIDOS DA PAISAGEM}

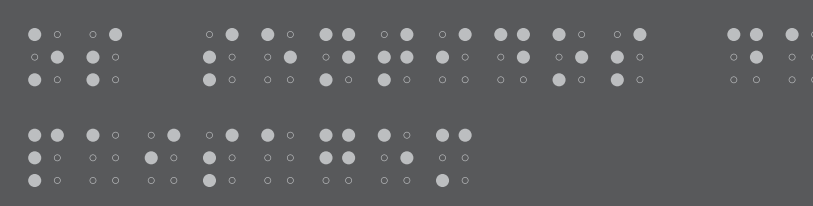

Men say they know many things

But lo! they have taken wings, -

The arts and sciences,

And a thousand appliances;

The wind that blows

Is all that any body knows.

Henry D. Thoreau ${ }^{1}$

Foi o Alexandre quem me mostrou o centro de São Paulo.

Era época de Natal e a convite de amigos sai com um grupo ${ }^{2}$ que visitaria o centro histórico.

1 THOREAU, Henry D. Walden or, Life in the Woods. New York : Dover, 1995, p. 27

Os homens tanto conquistaram; Vejam! Até asas tomaram - Artes, ciências; Mil exigências. E apenas do sopro do vento; O corpo tem conhecimento. Henry D. Thoreau. Walden, Tradução de Astrid Cabral. São Paulo : Global Editora, 1985, p. 50

2 Grupo Terra: http://www.grupoterra.org/ 

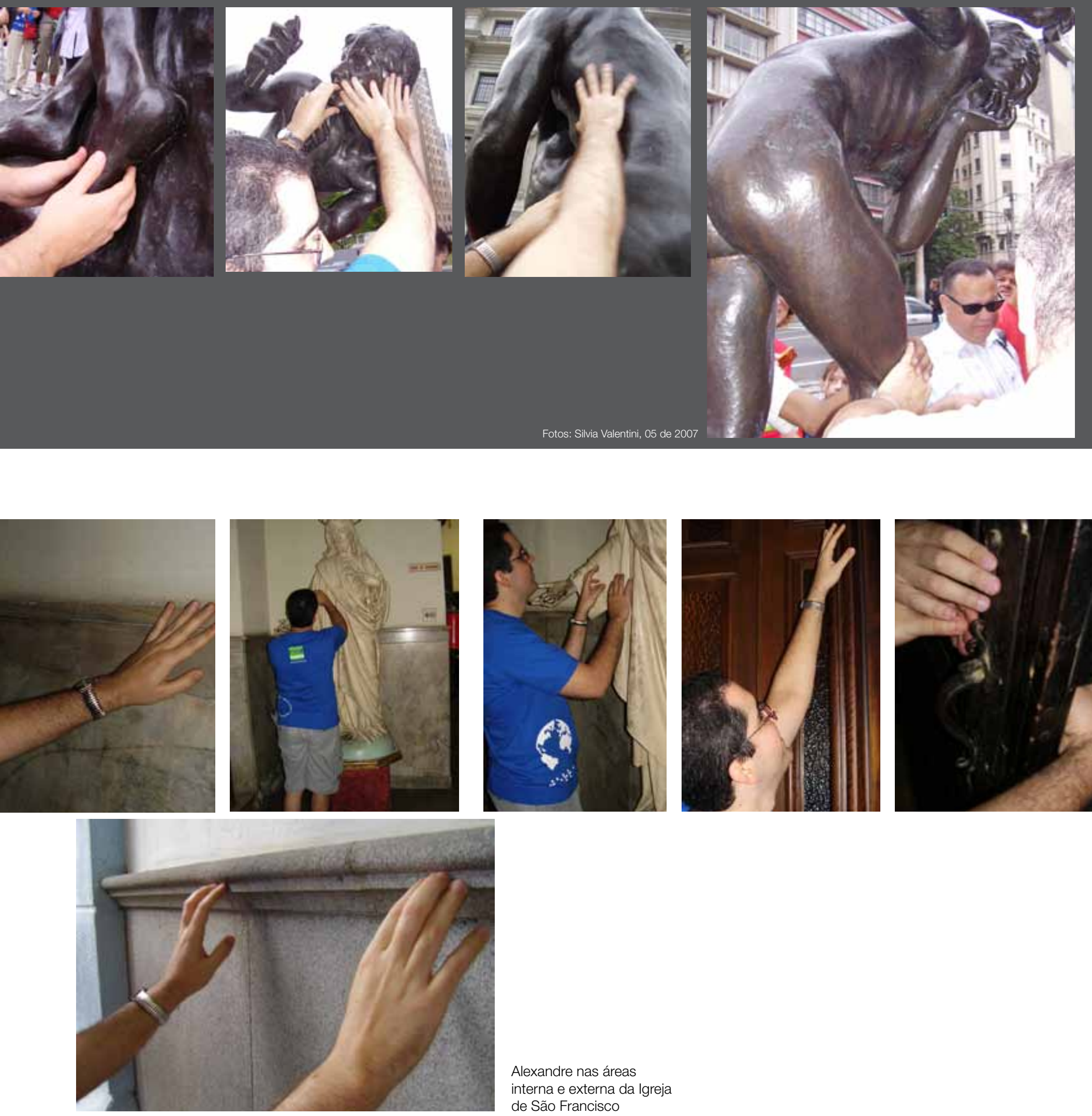

Alexandre nas áreas

interna e externa da Igreja

de São Francisco 
Antes do início do passeio formamos duplas: videntes e pessoas que não enxergam com os olhos. Naquela tarde fiquei de guiar o Alexandre, mas quem me mostrou a paisagem foi ele. Eu tinha chegado com câmera, gravador, equipada para vivenciar uma oficina de percepção. Não sabia que ficaria com o Alexandre, as duplas foram definidas no ponto de encontro.

Nós já nos conhecíamos, sabíamos um do outro. Analista de sistemas, 30 anos, oriundo de família do interior, mora em apartamento na Zona Sul da cidade, próximo ao metrô.

É muito mais fácil, porque hoje é o transporte mais rápido e porque os

funcionários têm um treinamento especial; é um lugar aonde vai muita gente, então é mais fácil de conseguir ajuda, morar perto do metro é maravilhoso, é a garantia de ir e vir, desde Gh da manhã até meia-noite.

Chegamos à Igreja de São Francisco. Em frente, duas estátuas. Alexandre se aproxima, toca uma delas, e percebe: olha as veias do pé, que barato! Muitos detalhes, legal! E passa a enumerar os detalhes:

Esse é o pé esquerdo, ele está sentado de frente para lá, onde a moça está falando. À sua esquerda tem o pé direito dele. Ah, ele está sentado de lado...

Dentro da igreja, visitamos uma exposição de presépios de várias partes do mundo. Cenas montadas dentro de caixas de acrílico transparente; cenários em argila, palha, miniaturas em metal, Menino Jesus deitado dentro de uma concha. Quando as imagens não podem ser tocadas, pessoas cegas ficam na dependência da audiodescrição, da interpretação de quem está narrando a cena. Alexandre me pergunta: capricham nos rostos dos personagens?

Surge um senhor tocando músicas de Natal em uma pequena gaita: paisagem sonora. Optamos por sair daquele ambiente e no caminho para o lado de fora da igreja tocamos o mármore das paredes, as saliências, os frisos. Descrevo o desenho inquieto do mármore de Carrara. Alexandre toca as colunas, mas não chega ao capitel. Se pessoas cegas se restringirem a experimentar o que lhes possibilita o alcance das mãos, conceitos como capitel, verga, bandeira, torre, beiral, cimalha, abóbada, presentes na igreja, ficarão reservados às pessoas que enxergam com os olhos. Mas a arquitetura deixa evidente que as qualidades do espaço, assunto e escala, podem ser percebidas com outros sentidos, além do olhar. 
Desvendo com Alexandre os encantos da grande porta de madeira da entrada, suas ferragens, almofadas, o espelho da fechadura, a aldraba e as dobradiças. Toda a experiência tocante à arquitetura é multissensorial e o tato é o sentido da proximidade, da intimidade, da afeição. O rapaz interessa-se por todos os detalhes e, numa verdadeira maiêutica, informa-se sobre os valores da época, desvelando um tempo de qualidades diversas.

\section{Essa igreja tem vitral?}

Lembro que a igreja de São Francisco formava, com as igrejas de São Bento e do Carmo, o triângulo central da cidade de São Paulo até o século XVIII. O convento foi construído a partir de 1639 e as paredes de taipa constituíam a "tradição construtiva da região de São Paulo"3.

Deixamos o ambiente interno para vivenciar o espaço da cidade. De fora da igreja, descrevo as características das sacadas com o guarda-corpo de madeira e lhe apresento a paisagem degradada: calçada de mosaico português com pedras soltas e espalhadas, muitos buracos. Moradores de rua, bêbados, lixo acumulado nos cantos, forte odor de urina. A cena, somada à algazarra de crianças de uma escola em visita aos presépios, interrompe a cronologia e nos faz despertar da nossa viagem de séculos atrás. A paisagem da religiosidade, o trabalho acurado da arquitetura se fragmenta na realidade atual, inquietante, deteriorada. Passamos, em segundos, da pomposa história para a paisagem efêmera e desvalida dos mendigos. É a paisagem se apresentando em sua constante transformação, em campos de embates e conflitos.

Afastamo-nos caminhando, tomando consciência da paisagem que vivenciamos. Atravessamos a rua discutindo a possibilidade de a cidade ter semáforos sonoros, desenvolvidos para que as pessoas cegas possam atravessar as ruas sozinhas, sem ajuda. Alexandre reflete:

\section{É preciso fazer uma campanha grande antes de colocar um sinal sonoro, porque as pessoas náo respeitam o sinal e a gente correria mais risco.}

Wirth ${ }^{4}$ coloca que "o relógio e o sinal de trânsito simbolizam a base da nossa ordem social no mundo urbano”. Para pessoas cegas, no entanto, o sinal pode trazer também inquietação, em uma cidade hierarquiza-

3 REIS FILHO, Nestor Goulart. São Paulo e outras cidades. São Paulo : UCITEC, 1994

4 WIRTH, Louis. O urbanismo como modo de vida. In: VELHO, Gilberto. O fenômeno urbano. Rio de Janeiro : Zahar, 1967 


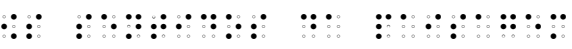

da onde cegos se sentem como cidadãos em desvantagem. A inquietação que a travessia no semáforo acarreta emerge também no depoimento da professora aposentada Sandra, relembrando os percursos da sua infância:

Para atravessar a Rua Líbero Badaró, eu ainda tinha um resíduo de visão e enxergava a luz do farol, distinguia a luz, mas não confiava. Então eu ia quando todo mundo ia, quando as pessoas se colocavam para atravessar eu também ia.

Fala com a autoridade de quem conhece. Assim como Alexandre e mais de 150 mil cidadãos paulistanos 5 , Sandra não enxerga com os olhos. A professora faz a leitura da paisagem usando a sua intuiçáo, sua pele, seus aparelhos olfativo, auditivo, enfim, todo o seu corpo. Desde criança habituou-se a percorrer a pé as ruas estreitas desta área da capital. Registra as características dos seus frequentadores, seus hábitos de comportamento e consumo no comércio local, fatos que descreve com a sabedoria de grande observadora e com detalhes revelados por uma memória prodigiosa. Atenta às condiçóes da caminhada, comenta sobre o piso de pedras portuguesas e os buracos perturbadores, semelhantes aos encontrados por Alexandre em frente à igreja:

\section{A bengala é um prolongamento da mão e detecta os obstáculos do caminho.}

A professora comenta que a bengala talvez esteja com a ponta velha, pois engancha em todos os "degrauzinhos", como ela chama as saliências que encontra no calçamento daquela rua.

Engancha, e se eu não tomar cuidado ela vem com toda força na minha perna e eu fico com marcas, porque machuca, se eu estou andando rápido eu dou o passo e a bengala fica e machuca. Agora estamos num piso que está parecendo um pouquinho melhor e é um tipo de lajotinhas, eu acredito, de pedrinhas (refere-se ao mosaico português)

A sensação de enganchar a bengala desencadeia um sentimento de inquietação. Além das marcas na perna, a sensação de descontinuidade da marcha, a possibilidade de estar sendo observada, o próprio descompasso e a desarmonia em relação a outros passos à sua volta compóem um arcabouço dissonante para quem deseja ser olhado e tratado como um cidadão comum.

5 Segundo o Instituto Brasileiro de Geografia e Estatística (IBGE), pelo Censo de 2010, vivem em São Paulo 151.842 mil pessoas cegas. 

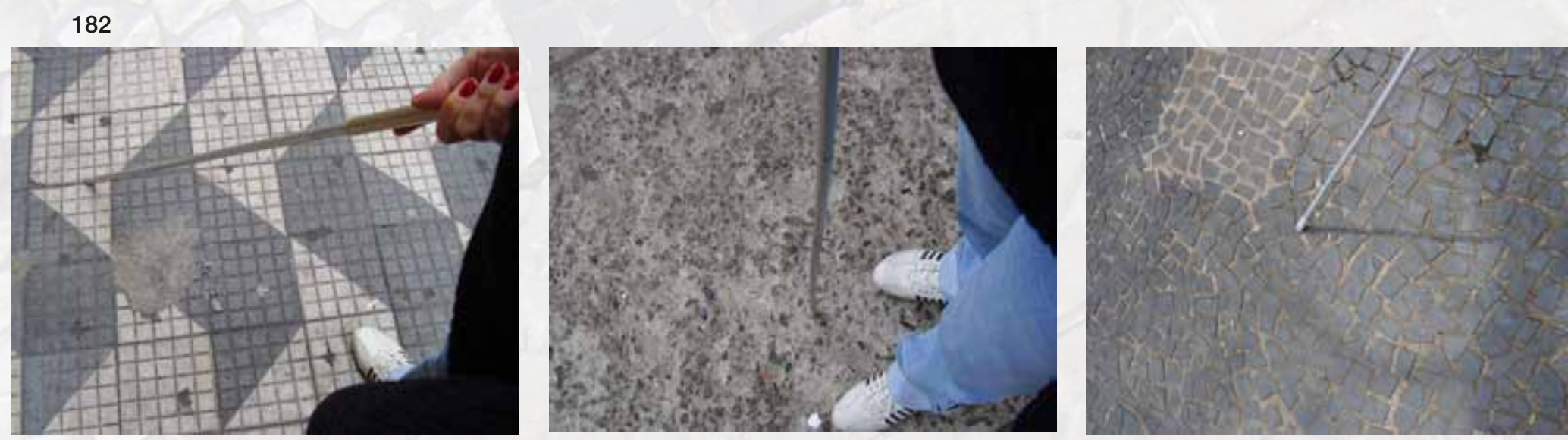

A bengala engancha nos degrauzinhos e nas imperfeições da calçada.
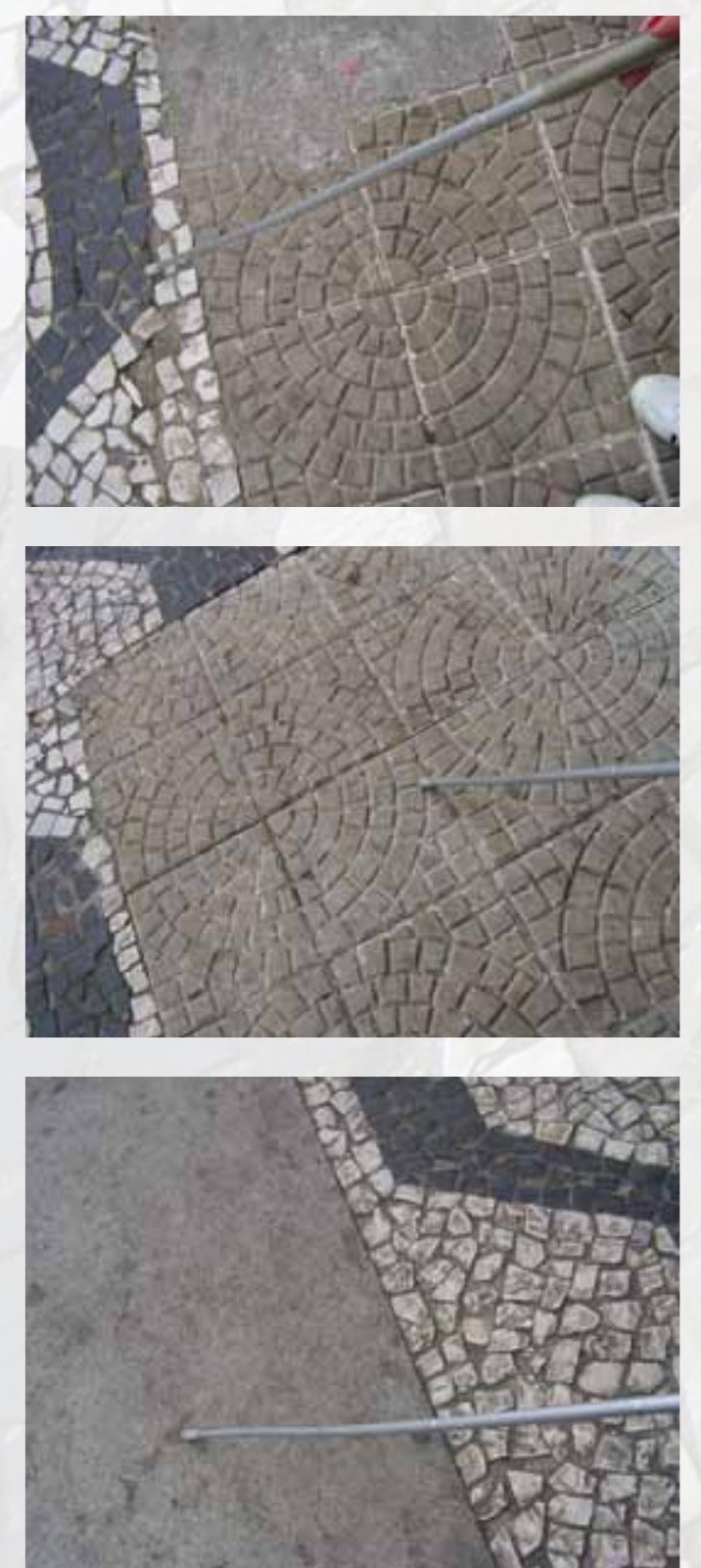

Três variedades de piso: o ladrilho é o pior, e o piso de cimento liso é o melhor. 


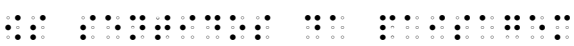

Aqui a calçada está simplesmente horrivel (novamente o mosaico português). Aqui a gente tem três variedades de piso, aqui é mosaico português, aqui é outro piso que engancha a bengala, aqui é melhor.

Com percepção acurada, Sandra experimenta essas texturas como arremates de espaços vividos. Acaricia as superfícies com a ponta da bengala, sente na mão as diferentes vibraçóes, alisa, toca, bate, inquieta-se. No plano da cidade, as superfícies dialogam e transmitem mensagens repletas de significado, garantias para seguir adiante. Estendemos a percepçáo háptica com um instrumento, e nesse caso o sentir de um objeto move-se para o final da bengala. Mas, quando estendemos a visão ou o som telescopicamente ou eletronicamente, continuamos a ver e a ouvir figurativamente e a distância.

$\mathrm{Na}$ caminhada com Alexandre, estranho a falta da bengala e pergunto sobre ela. $\mathrm{O}$ rapaz explica que ela é útil quando está sozinho, mas quando está com alguém em quem confia, em lugar tranquilo, prefere não usar a bengala para deixar as mãos livres: Ela é muito útil enquanto está sendo usada, mas depois é um problema sério. Eu a coloco no bolso. Schiffman descreve como a bengala de pessoas cegas auxilia no rastreamento do caminho a ser trilhado e fornece informaçóes sobre o espaço (SCHIFFMAN 2005, p. 267). A ponta da bengala não apenas rastreia a superfície mas, ao tocar o solo, produz sons que geram ecos e funcionam como orientador das pessoas cegas.

Temos em Frampton ${ }^{6}$ :

O Regionalismo Crítico enfatiza tanto o tátil quanto o visual. Tem consciência de que o ambiente pode ser vivenciado em outros termos, não somente através da visão. É sensível a percepçóes complementares como níveis variáveis de iluminação, as sensações ambientais de calor, frio, umidade e deslocamento de ar, bem como à diversidade de aromas, sons produzidos por materiais diferentes em diferentes volumes e até mesmo às sensaçóes variadas induzidas pelos acabamentos dos pisos, que levam o corpo a passar por mudanças involuntárias de postura, modo de andar etc. (FRAMPTON, 2003, p. 397)

Quando perdeu a visão, Daniel teve que reaprender a caminhar pelo bairro, no entorno da sua casa. E só então conheceu detalhadamente o local, as texturas, a localização dos postes, os obstáculos, as facilidades. Agora, como um datilógrafo cujos dedos conhecem de cor a posição das teclas, Daniel re- 
conhece no poste fora de lugar o seu caminho e o tem como parte das feições e características da cidade onde vive. Como nos mostra Merleau-Ponty:

[...] o sujeito que aprende a datilografar integra o espaço do teclado ao seu espaço corporal. [...] o hábito não reside nem no pensamento nem no corpo objetivo, mas no corpo como mediador do mundo (1994, p. 201). A exploração dos objetos com uma bengala [...] também é um exemplo de hábito perceptivo. Quando a bengala se torna um instrumento familiar, o mundo dos objetos táteis recua e náo mais começa na epiderme da mão, mas na extremidade da bengala (1994: 210). A bengala não é um instrumento que o cego percebe, mas sim com o qual percebe, um apêndice do corpo, uma expressão da síntese corporal. (MERLEAU-PONTY, 1994, p. 211)

Nesse sentido, Daniel nos aponta as condiçóes necessárias para o entendimento do espaço:

Minha mobilidade tem melhorado bastante graças à boa evolução do manuseio da bengala e da percepção dos outros sentidos. Sinto que minhas caminhadas seriam mais agradáveis se o material utilizado nas calçadas da USP fosse outro. As atuais lajotas de concreto com o passar do tempo ficam desniveladas e com algumas peças soltas. Isso dificulta a execução do arco com a bengala, pois o "roller" prende-se com muita facilidade. Torna também o percurso mais inseguro, sujeito a tropeços e torçóes do pé. As caminhadas tornam-se mais cansativas e exigem atenção redobrada diminuindo um pouco o prazer do passeio. Sem dúvida, seria muito mais agradável andar em calçadas mais lisas, com menos irregularidades, apenas apreciando o espaço que é muito bom. A melhoria da qualidade não depende das medidas muito caras: maior capricho no acabamento e na colocação das lajotas juntamente com uma manutenção preventiva evitaria que as peças de desprendessem. Em alguns trechos (não sei se já alcançou toda a Cidade Universitária) as calçadas foram construidas utilizando-se outro material. Nestas novas calçadas utilizou-se o asfalto (o mesmo das ruas) o que tornou o piso mais liso. Sem duvida é melhor para fazer o rastreamento com a bengala, pois ela desliza com mais facilidade. Apesar de apresentar menos irregularidades que as calçadas de lajotas, elas são bastante presentes pois a falta de preparo adequado do solo durante a construção, acaba provocando o aparecimento de buracos e afundamentos no piso. 
Daniel completa:

Outro aspecto que deve ser observado é a falta de uma sinalização indicando as guias rebaixadas. Como o material da calçada e da rua é o mesmo, um cego pode ter dificuldades em se localizar com precisão, levando a uma situação de risco. Essas medidas realmente tornariam os passeios na USP muito mais gostosos, pois lá é possivel fazer-se longos trajetos sem necessidade de muitas travessias, o que proporciona maior autonomia, ou seja, menos preocupaçáo e mais prazer.

Merleau-Ponty (1994 p. 303) aponta que o corpo percebe e que os sentidos se comunicam, embora o campo tátil não tenha a mesma amplitude do campo visual. Segundo Daniel, o excesso de barulho nas ruas da cidade é um dos principais causadores de incômodo em minhas caminhadas. Ainda necessito ouvir o toque da bengala para caminhar com desenvoltura e tranquilidade. Com barulho isso é impossivel.

Em artigo publicado no jornal $\mathrm{O}$ Estado de Sáo $\mathrm{Paulo}^{7}$ o arquiteto e urbanista Cândido Malta reflete sobre "a relação do trânsito com as pessoas nas ruas, nas calçadas e nos lotes lindeiros de suas casas: um veículo a cada 20 segundos seria o ideal, mas um a cada 10 não é mau. Corresponde a um movimento de 200 a 500 veículos por hora. Agora, acima de 500, já perturba. Se chegar a mil, que é o limite da faixa, para, incomoda, afasta gente da rua”. 

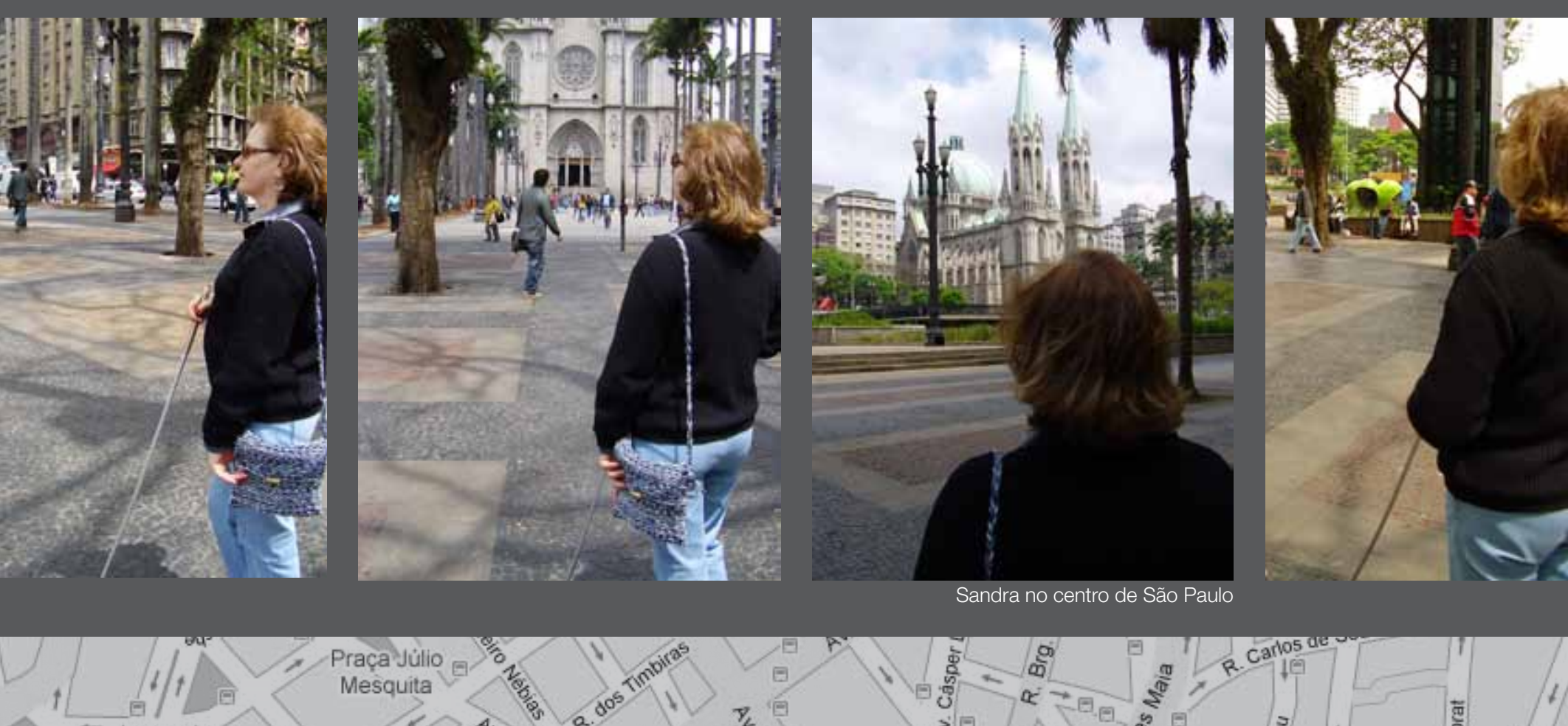

Praça Jülio 12

— Largo do

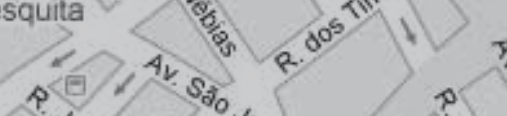

२. Sant

ta Isabel

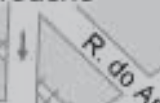

$+1$

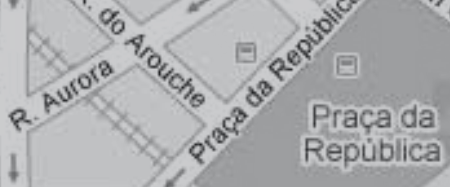

R. Marqués de ltu
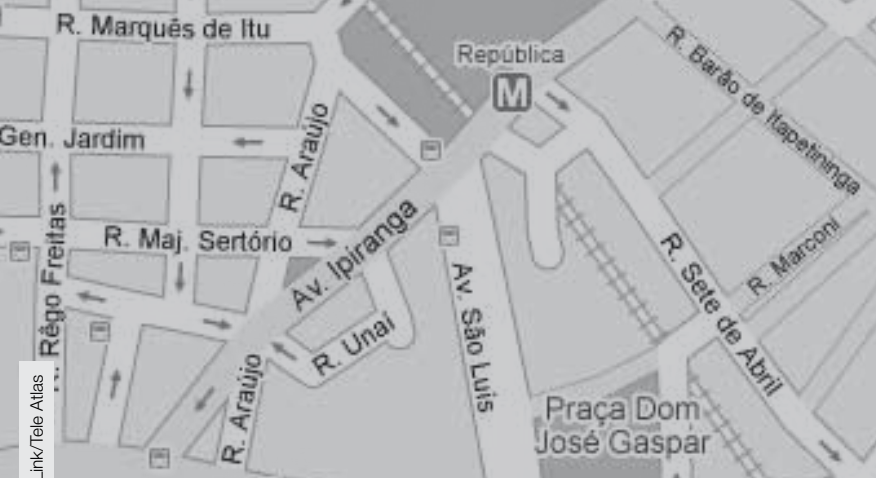

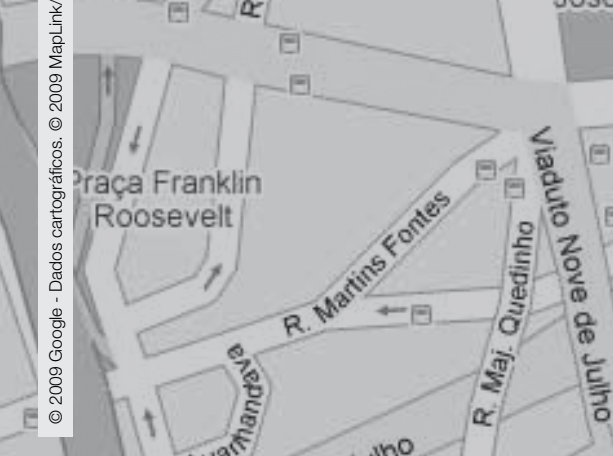

Praça Dom

R. Avas av. 9 de julino

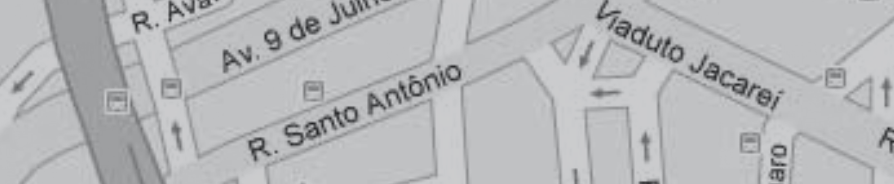

:

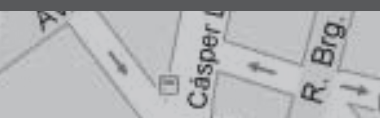

- 10

cantos 


\section{O compasso da metrópole}

\section{A paisagem pensa-se em mim e eu sou a sua consciência. ${ }^{8}$}

\section{Cézanne}

O centro de São Paulo é um território mapeado na memória de Sandra. Porém, segundo Lefevre? a cidade passou por transformaçóes tão radicais nas últimas décadas "que se torna difícil estabelecer um quadro de referências concretas para transmitir essas transformaçóes para quem não esteja habitualmente familiarizado com referências que já desapareceram".

Refazendo o mesmo percurso para o Colégio, 50 anos mais tarde, Sandra dispóe novamente a urdidura complexa que desafiava o seu entendimento do espaço urbano e a incitava a expandir os seus territórios. A incapacidade de dominar o espaço de relaçóes alteradas causa uma sensação de não pertencimento, embota a percepção dos sentidos, preocupa, desestabiliza.

Estamos próximo à Rua Barão de Paranapiacaba, repetindo o caminho feito no início dos anos 60 . Pergunto como era aquele trecho e Sandra explica que passavam por canteiros que náo eram retos e que era tudo gramado, muito bem conservado. E constata que naquela época, como hoje, já sentia cheiro de urina e ouvia os sons das lojas de discos. Havia também muitos vendedores ambulantes que ficavam à beira da calçada, vendendo tabuada. A constatação da presença de vendedores carrega uma carga de descontentamento.

Onde tem a Catedral era uma calçada e, atravessando essa rua, formava como se fossem várias ilhas de ônibus. Agora parece que tem chafariz, lago, e antigamente não, eram essas ilhas que separavam os pontos de ônibus com aquela cabaninha de, não sei que material, não era cimento, era uma cobertura. Os postes que seguravam essa cobertura eram em formato de duas colunas redondas apoiadas sobre um degrau e elas começavam unidas em baixo e se separavam em cima para segurar os toldos dos ônibus. Era simpático, era bonitinho, eu achava. Se agora nós estamos de frente para a Catedral, a Rua Paranapiacaba, ela fica nas minhas costas, não, à nossa esquerda. O piso aqui está melhor, parece que é calçadão, como você falou, mas antigamente era uma rua estreita, não passava carro, mas era uma rua. 
O espaço é partilhado por policiais, ambulantes, pedestres, mendigos, pessoas que transitam rapidamente e não se percebem. Espaço aglutinador, de manifestações públicas, de mendicância, encontros e convívio de cidadáos, local de expor-se e resguardar-se. Rezas, lembranças, a praça tem caráter simbólico na história da cidade e se apresenta agora em sua nova configuração, ainda desconhecida, prestes a ser desvelada pela professora.

Sandra comenta que a Rua Barão de Paranapiacaba é conhecida como 'rua dos ouros'. Há várias joalherias populares com vendedores que anunciam jóias de ouro e prata, incitando possíveis compradores. Lembra-se de que quando vinha para a cidade com a mãe, paravam para ver artigos chineses e bordados finos da Ilha da Madeira, o que para ela significava o desconhecido, o enigma velado de terras distantes.

E o que tem de interessante nessa rua é uma coisa muito pitoresca, pelo menos para mim. À nossa esquerda, quando termina na Quintino Bocaiuva, tinha uma doceira chamada doceira Pão de Açúcar. E tinha uma senhora muito, muito loira, que hoje eu diria que seria albina, mas eu perguntei para a minha mãe e ela disse que não é. Mas ela era muito, muito loira e eu adorava um sonho que tinha ali. E entâo, algumas vezes, quando a minha mãe vinha me buscar, ela parava e comprava um sonho só, porque a gente não tinha condiçóes de comprar para todo mundo. Eu me sentia assim a mais premiada de todas. Essa parada era na volta do colégio. Eu vinha pensando: tomara que ela pare, tomara que ela pare. Eu náo tinha coragem de pedir porque eu sabia que a nossa situaçấo financeira era um pouco complicada e eu ficava chateada dela comprar só pra mim, para os meus irmãos não, então eu não tinha coragem... Quando ela dizia: - Você quer? Eu dizia: - QUERO! Não esperava nem acabar (ri), eu gostava demais. Muito, muito interessante, eu me lembro da fisionomia da mulher, fisionomia não, da voz e do cabelo loiro. Chamava muita atençâo. Tinha aquele cheiro maravilhoso de doceira (doçaria), gostoso, de forno assando coisas fresquinhas. O som era tranquilo, não tinha essa barulheira que tem hoje na rua, a rua era bem movimentada de transeunte, mas não era assim tão cheia desse som que a gente está ouvindo.

Sandra naturalmente refere-se à gritaria dos ambulantes. A fruiçáo de um espaço táo importante para ela não deveria incluir tropeços em barracas, ruído de vozes altas, sensação de confusão e tumulto. Outras lembranças, porém, são sentidas com um toque de magia. O relato da expectativa de que a máe parasse para comprar o doce interrompe a respiraçáo. O cheio adocicado, o creme que recheava o sonho 
e se espalhava logo na primeira mordida afastavam a preocupação com os parcos recursos. A narrativa é feita com tanta emoçáo que sabe a perfume de baunilha. É como se a professora revivesse Proust nas manhãs em Combray e o sabor das madeleines de tia Leôncia (PROUST, 1972, p. 47).

Recorda a tranquilidade das ruas José Bonifácio e Sáo Bento, das calçadas estreitas e do pouco movimento de carros que permitia às pessoas andarem pelo meio da rua. $\mathrm{O}$ local deixava de ser apenas um caminho de passagem e adquiria feiçóes de um espaço de experiências sensórias. Reconhece novamente as lojas pelos cheiros que têm: de couro? Vem da loja de malas da esquina, onde a mãe comprava, a Império dos Couros, Rua Quintino Bocaiúva, 79. Havia uma antiga loja de sapatos chamada Casa Vermelha e também a Chapelaria Paulista, onde o avô comprava o Borsalino. Visitando a chapelaria, soubemos pelo vendedor que o modelo não é mais fabricado, foi substituído pelo Ramezoni, hoje mais procurado pelos jovens.

Entramos na Rua José Bonifácio, antiga rua de paralelepípedos, hoje calçadão. A impressão que hoje o lugar passa é de descuido. Cheiro de creolina, vendedores anunciando ofertas: "masculina e feminina, vamos aproveitar a promoção, vinte sete e cinquenta”. Já na esquina da Rua Paulo Egídio sentimos cheiro de loja de tecidos de cama, mesa e banho. As cores fazem parte da memória cultural:

Naquela ruazinha entravam moças com um uniforme lindissimo, era uma saia verde, pregueada, com cinto e uma blusa branca com um bordado em verde do mesmo tom. Eu achava aquilo maravilhoso porque todos os uniformes eram azul marinho, blusinha branca, enfim, variava só o bordado da blusa e esse era verde. Uniforme da Escola de Contabilidade Álvares Penteado. Era lindo, eu ficava encantada. Eu via o verde da saia e achava bonito e logo que eu comecei a vir para a cidade a minha avó vinha comigo e ela dizia que era de uma escola e que tinha o bordado no bolso da blusa e depois, eu não sei te dizer exatamente quem, mas alguém me contou que era da Álvares Penteado. Lindissimo. Uma vez, eu vinha voltando da escola de braço dado com minha máe e ela andava sempre muito rápido porque tinha muita coisa pra fazer e também porque eu acompanhava super bem, não tinha problemas. Equando chegou na Rua São Bento, o movimento de pessoas era muito grande e um homem vinha vindo na minha direção e não sei se a minha mãe não viu ou não desviou, ele bateu no meu óculos e o óculos voou longe e quebrou e eu comecei a chorar desesperada porque minha mäe tinha dito que aquele óculos tinha que durar muito porque tinha custado muito caro e eu dizia pra ele: - O senhor tem que pagar! E minha mãe dizia: - Não tem importância! E eu chorava desesperada!

$\mathrm{O}$ relato vem carregado de emoção. Qual é a dimensão do sentimento de perda de um bem tão precioso, quando se constata a dificuldade para obtê-lo? Ao invés de palco de conflitos, a cidade não 
deveria permitir interaçóes harmoniosas? Esta seria a diferença entre cidade idealizada e a realidade, cenário de desavenças? $\mathrm{Na}$ poesia de Dickinson ${ }^{10}$ conferimos como o tempo não nos deixa esquecer:

"Dizem, 'com o tempo se esquece', / mas isto não é verdade / Que a dor real endurece / Como os músculos, com a idade. / O tempo é o teste da dor / Mas não é o seu remédio / Prove-o e, se provado for, / É que não houve moléstia”. (DICKINSON, 1984, p. 100)

Entramos na Rua São Bento, hoje um calçadão, que a professora lembra como sendo mais uma rua com calçadas estreitas, típicas do centro. O Guia do Estado de São Paulo aponta que, em 1962, as principais ruas do comércio varejista de São Paulo eram: Direita, São Bento, Líbero Badaró, José Bonifácio, Benjamin Constant, Quintino Bocaiúva e Praça da Sé. Nas ruas de maior movimento comercial, segundo o Guia, eram comuns os sobrados antigos e havia poucos arranha-céus, embora ali os terrenos fossem muito valorizados. Bancos, repartiçóes públicas, escritórios, lojas, consultórios, levavam para o centro da metrópole uma multidão de pessoas que transitavam incessantemente pelas ruas. A capital teria na época 3,5 milhóes de habitantes, sendo a maior cidade das zonas tropicais. Este é o cenário que hoje revisitamos na memória.

Neste trecho ouviam-se sons de piano que vinham de uma loja de instrumentos musicais, lindissima.

Náo se lembra o nome, seria a Casa Bevilacqua, que vendia instrumentos e partituras? Ou a famosa Casa Manon? "[...] à Rua São Bento existiam três casas que com o tempo, desapareceram: Casa Beethoven, A. Di Franco e Casa Sotero"11. O passeio pela cidade incluía todos os tipos de sensaçôes. As notas musicais vinham saltitando, fazendo cócegas nos ouvidos, enquanto que os gritos dos ambulantes chegavam para quebrar o encanto. Os artigos chineses e bordados finos da Ilha da Madeira, ali vendidos, traziam o mistério de regióes distantes. Tocar um tecido desconhecido, de tanta importância, era como vivenciar uma viagem pelo imponderável.

10 "They say that 'Time assuages' / Time never did assuage / An actual suffering strengthens / As Sinews do, with age / Time is a Test of Trouble / But not a Remedy / If such it prove, it prove too / There was no Malady."

DICKINSON, Emily. Uma centena de poemas. Tradução de Aíla de Oliveira Gomes. São Paulo : EDUSP 1984

11 SESSO JR., Geraldo. Retalhos da Velha São Paulo. In: APROBATO FILHO, Nelson. Kaleidosfone. São Paulo, EDUSP, 2008, p. 212 
Passamos pela Praça do Patriarca, Igreja de Santo Antonio e Sandra se lembra do acesso à galeria Prestes Maia, onde comprava os passes escolares: os meninos maiorzinhos gostavam muito porque era uma das poucas escadas rolantes que tinha aqui no centro. Ainda tem? Estamos na frente dela. Descrevo os detalhes da obra de Paulo Mendes da Rocha e a descida para a galeria. Tocamos as colunas facetadas.

Lindas, é mais ou menos da época do Teatro Municipal? Nossa, é larga, não? Por que algumas faces estão bem lisinhas e outras não? A gente comprava passe aqui à esquerda. Era aqui mesmo, bem próximo à saída do outro lado.

Percebemos funcionários varrendo a área externa com vassouras de folhas de palmeiras, com movimentos largos, como que acariciando o mosaico. As lembranças que compóem a narraçáo poética das memórias de Sandra se confundem com a poesia urbana do passeio. Bachelard relata a história de um varredor de ruas de um romance italiano, "que balançava sua vassoura com o gesto majestoso de um ceifeiro. Em seu devaneio, ceifava no asfalto um prado imaginário, o grande prado da natureza real em que reencontrava a sua juventude, o grande ofício do ceifeiro ao sol nascente" (BACHELARD, 1993, p. 81).

Tateamos as esculturas de Brecheret, compartilhando a cultura paulistana e a estética expressa no local; subimos as escadas para sair da galeria em direção à Rua Líbero Badaró, a caminho do Viaduto do Chá. Bem no meio do caminho encontramos uma caixa de correio e um poste antigo, que é lindo, por sinal, mas não para estar aí-observa Sandra.

Mas esse viaduto era de calçada bem mais estreita. Agora passam carros, mas foi diminuido o leito carroçável e foi aumentada a calçada e eu náo sei se o piso ainda é, mas antigamente tinha um quadradinho bem pequeno, bege, eu acho, mas muito bonito.

Guarda-corpo? Ah, eu não sabia que chamava isso. Eu nunca parei aqui na grade, no beiral, porque não dava tempo. Edepois porque não tinha o interesse que tem hoje, era um local simplesmente de passagem, a gente não dá o valor que dá hoje. E aqui a gente está bem na frente do prédio que era o antigo edifício Matarazzo. Que hoje é a prefeitura. Eu me lembro que era um prédio bonito, limpo, clarinho, não sei como está hoje e esse espaço aqui era um lugar que não tinha camelô, não tinha banquinha.

Ouvi muitos casos de gente que se atirou daqui... Eu passei às vinte para as sete da manhä, depois eu passava às cinco e meia da tarde, depois ao meio-dia, em diversos horários quando eu estava estudando. Andava bastante e eu me sentia muito mal quando eu passava ao meio dia por causa do sol, aquilo me incomodava muito. 
São duas horas da tarde, estamos com o sol à nossa frente, Sandra se lembra de quando chovia.

A gente tinha guarda-chuva, capa e galocha. Porque quando chovia muito não podia chegar na escola de pés molhados, ia ficar a manhã inteira de pés molhados, então minha mäe dava galochas, era horrivel, era muito feio, eu não gostava, acho que eu era a única que usava e quando eu chegava a primeira coisa que eu fazia era tirar as galochas. E muitas vezes aqui no viaduto, quando ventava muito o guarda-chuva virava e eu tinha vontade de chorar porque a gente se molhava à beça, não protegia nada e a gente tinha que carregar junto com a mala, não tinha mochila naquela época. Ficava com as mãos ocupadas e acabava se molhando do mesmo jeito.

A professora relata que percebia o início e o fim do viaduto pelos dois prédios que ficam nas extremidades.

Eles seguram o vento, então a gente percebe nitidamente que está chegando nas extremidades. Mas ai fica mais dificil pra gente andar porque com bengala, por exemplo, não tem um senso de direção, ao passo que quando você vem em linha reta só, tem o muro, a calçada, e antes com a calçada que era mais estreita também ajudava. Agora é mais confuso. Agora nós vamos seguir em frente, atravessar a Xavier de Toledo, atravessar aonde era o Mappin, tinha um relógio aqui. Quadrado!

Não via as horas, mas conseguia enxergar o relógio. E se lembra também da passagem por debaixo da Rua Xavier de Toledo.

Aqui nós estamos bem em frente à calçada onde era a Loja Mappin. Aqui na época de Natal ficava cheio de pessoas que se acotovelavam e não tinha camelô, vendedores ambulantes, como não tem hoje também, né? À nossa direita está o teatro, nós chegamos a fazer várias vezes reivindicaçôes, a gente chegava ai, ficava sentado, contra qualquer coisa que eu nem sei o quê. Eu me lembro das caixas de sapatos do Mappin, elas eram brancas e na extremidade elas tinham uma etiqueta escrito Mappin. Ela era toda verde e escrito Mappin com dois " $p$ ". A etiqueta era verde escrito em branco e o papel que embrulhava os presentes era verde escrito em branco. Depois de muitos anos eles trocaram por papel branco escrito em verde. 

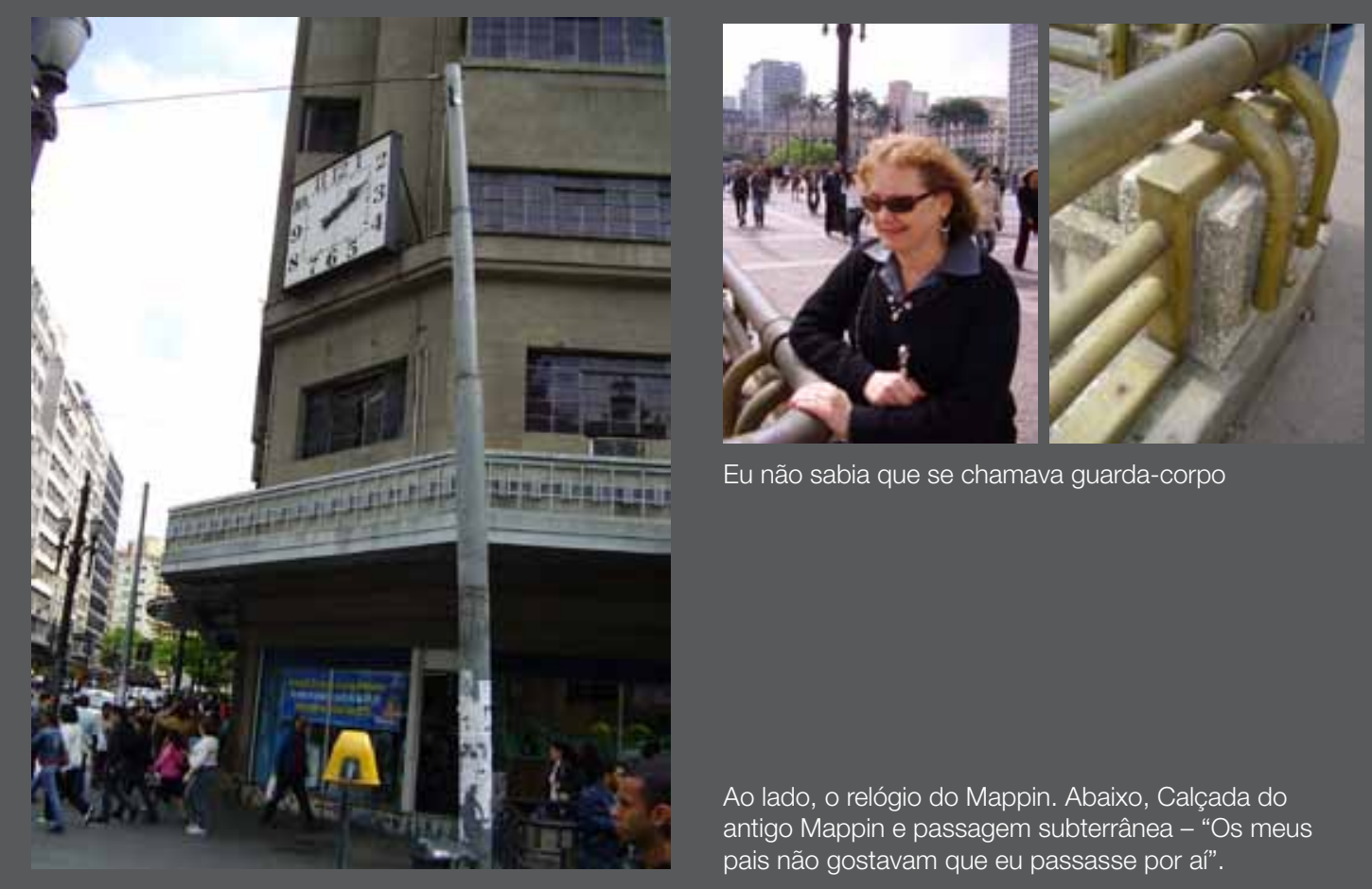

Ao lado, o relógio do Mappin. Abaixo, Calçada do antigo Mappin e passagem subterrânea - "Os meus pais não gostavam que eu passasse por aí".
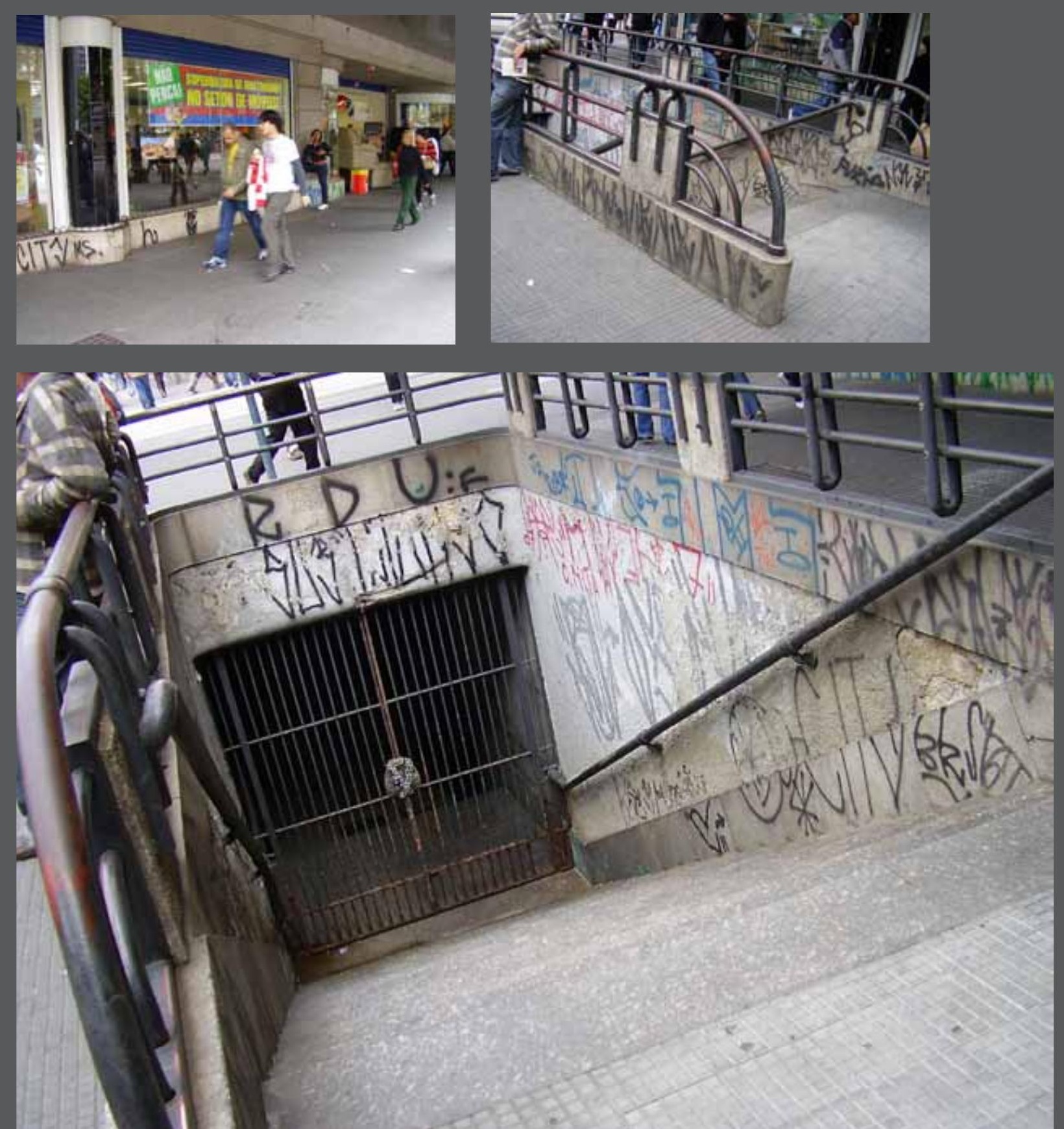
Deixando a lembrança dos presentes embrulhados em papel verde, Sandra relata os momentos de tensão vividos em 1964. Era, provavelmente, março e o comando do IV Exército articulava a derrubada de João Goulart com a tropa de choque nas ruas, ocupando o entorno da Faculdade de Direito para impedir o pronunciamento de João Pinheiro Neto ${ }^{12}$.

Agora aqui nós vamos chegar na Conselheiro Crispiniano. Nessa rua, em 64, uma tarde o colégio dispensou os alunos para que todos fossem imediatamente para casa, que tinha muita polícia nas ruas. E nós viemos, eu e o meu irmáo pequeno, caçula, e eu me sentia totalmente responsável por ele, claro. Nós atravessamos a rua, ele olhou para o lado esquerdo e falou: - Nossa, está cheio de polícia com metralhadora. Me deu uma tremedeira tão grande que eu acho que nós chegamos na praça da Sé em dez minutos de tanto medo que estávamos sentindo os dois, porque a gente náo sabia o que estava acontecendo. Depois é que a gente ficou sabendo que era a revolução de 64 e tudo mais.

Já na Rua Barão de Itapetininga, Sandra se recorda de como era difícil andar, na época da construção da galeria.

Essa rua tinha calçada e o leito carroçável. Aqui já passava carros e à nossa esquerda tinha uma construção que passou bastante tempo para ficar pronta. Tinha uma porção de tapumes e os tapumes ficavam na calçada e era desagradável para passar por ali. Mas foi quando construiram a Nova Barão, a primeira galeria aberta de SP, pelo menos é o que diziam na época. Aqui era um centro novo, melhor que a Rua Direita, a Rua São Bento. Tinha uma loja à nossa direita, chamada Los Angeles, de roupa masculina e feminina, mas muito, muito fina e então a minha mãe comprava algumas coisas pra gente e marcavam muito porque eram peças caras que a gente usava demais demais, demais. Tinha outra loja aqui, esquina com a Praça da República, uma loja chamada Boa Viagem, vendia malas, bolsas, essas coisas.

A chegada na Dom José de Barros contraria a impressão de rua elegante, local de compras distintas. A área é marcada por forte cheiro de fritura. Lanchonetes populares, pastelarias, presença de ambulantes depreciam o local e pintam um quadro de degradação. É nítida a diferença na ocupação do espaço. Ela não se 
disfarça na paisagem, mas, sim, evidencia a contradição entre os fatos relatados e a realidade atual, com a qual nos deparamos. Sandra imediatamente percebe o calçamento de mosaicos: é aquele que faz ondas? Está bom, a bengala não prende. Relembra com nostalgia o tempo em que usava roupas elegantes para ir à Rua Marconi.

Eu me lembro que as lojas nessa rua tinham um preço bem diferenciado. Na Dom José de Barros e na Marconi, que ela é só à esquerda da Barão. Aqui eu conheço bem. E a Dom José, seguindo em frente, a gente vai sair na 24 de Maio, ali tinha a Mesbla, cheguei a ir algumas vezes. Era uma rua muito gostosa aqui, cheguei a ir a cinema, aqui na galeria Barão, talvez Cine Barão, vim algumas vezes. E quando chegava perto da Praça da República, em vez da gente virar à esquerda, a gente algumas vezes cortou por uma galeria que saía na Sete de Abril. Não me pergunta por que. Eu não sei, talvez porque tinha muito sol. Uma galeria bonita, logo na entrada do lado de cá tinha uma loja de flores, vendia orquideas, não tinha essa gritaria de camelô.

Chegamos à Avenida Ipiranga, viramos à esquerda e à nossa direita já está o jardim da Praça da República. Na medida em que nos aproximamos da antiga escola, deixamos para trás os traços de memória da cidade para antecipar as vivências internas do prédio. Sandra se lembra do coreto e das aulas que cabulavam em dias de shows de música popular. Na esquina da Rua Sete de Abril com a Avenida Ipiranga passamos por um piso tátil imperceptível para Sandra, como tantos outros presentes na cidade. Saliências perceptíveis apenas aos olhos.

Aguardamos, no trânsito irritante de automóveis, para atravessar a Avenida Ipiranga e ganhar a praça, com todas as emoçóes ali contidas. Enquanto esperamos, Sandra relata a sensação que foi a inauguração do Hotel Samambaia e o uniforme dos funcionários. Eles usavam uma capa bordô, eu cheguei a passar bem pertinho e ver a cor. Era muito bonito pra época, uma coisa nova, recorda. Sobre a presença dos hotéis nessa regiáo, Lefèvre (2006, p. 2) aponta que, nos anos 60 e 70, foram eles os responsáveis pela concentração de lojas de passagens e agências de viagens nos pisos térreos da maior parte dos prédios da Rua São Luiz. O Hotel Samambaia transformou-se hoje em prédio residencial, conta Claudinei ${ }^{13}$, porteiro do edifício.

Ao contrário do que acontece com Sandra, visitar o centro de São Paulo tem sabor de novidade para Alexandre. Como outras tantas pessoas cegas, o rapaz sente prazer em sair para caminhar e colocar ar e sol em seus pensamentos, como sugeria Thoreau ${ }^{14}$, mas não como andarilho errante, a flanar. Em

13 Edifício Samambaia, Rua Sete de Abril 422; telefone da portaria: (11) 32591685

14 THOREAU, H. D. Caminhando. Rio de Janeiro : José Olympio, 2006 
$\therefore \quad \because \because \because \because \because \because: \quad \because \because \quad \because \because \because \because: \because \%$

seus percursos, pessoas com deficiência visual se apóiam em um mapa mental e a ideia da deriva, o perder-se nas ruas da cidade, ao contrário de prazer, traz sensação de insegurança, principalmente para quem faz as suas primeiras incursóes pela metrópole.

No nosso roteiro de descobertas, visitamos uma exposição no Centro Cultural Banco do Brasil. Alexandre relaciona-se intensamente com aquela paisagem, já a partir da cantaria de granito da fachada do prédio. Com a pedra estabelece uma relação de reconhecimento e interação: É legal isso! Chamo a sua atenção para uma guarnição de granito, cujas partes superior e inferior têm texturas diferentes. Observo que o trabalho é todo feito à mão e o rapaz se surpreende, faz o reconhecimento e apropria-se da superfície da pedra: toca, sente, confia, entrega-se. A relação íntima com a textura produz uma observação:

\section{Engraçado que isso aqui parece que é um intermediário, porque você nota que a aspereza é diferente.}

Diz isso apontando para uma terceira parte, intermediária às duas que lhe mostrei. É final de tarde, a luz difusa não me deixa perceber muito bem o que ele aponta, os meus olhos não reconhecem. Toco o granito, no ponto onde estão os seus dedos e só então sinto uma terceira textura, imperceptível aos olhos. Comento surpresa que até então só tinha visto duas texturas. A necessidade de tocar o granito para reconhecer o que a visão não explicita, traz Caravaggio ${ }^{15}$.

Alexandre vivencia a paisagem com alegria genuína, quase infantil. Tudo lhe interessa e age como se pensasse a cidade a partir daquele momento. Explico os conceitos de fachadas moderna e antiga, as características de uma parede de vidro de um banco e a cantaria cheia de reentrâncias e saliências dos prédios antigos. $\mathrm{O}$ rapaz comenta que o banco é liso e que parece bem mais simples. As texturas da cidade podem adentrar o corpo de quem as toca para estabelecer relaçóes de reconhecimento. Os sentidos comunicam-se entre si.

Pessoas que enxergam muitas vezes não levam em conta que pessoas cegas possam perceber diferenças arquitetônicas e viver dentro dos padrôes de videntes. Em Acessible Environments, Mace; Hardie; Place $^{16}$ apontam que arquitetos muitas vezes observam que seus clientes náo consideram pessoas com

15 CARAVAGGIO, Michelangelo Merisi. A incredulidade de São Tomás. 1601-1602. Óleo sobre tela, $107 \mathrm{cmX146 \textrm {cm } . ~ I m a - ~}$ gem impressa na capa do livro The eyes of the skin, de Juhani Pallasmaa. Disponível em: http://caravaggio.com/preview/home.html http://caravaggio.com/preview/database/index.php?id=000121\&opmode=d\&r=undefined

16 PREISER, Wolfgang F. E. Editor. Design intervention - toward a more humane architecture. New York : Van Nostrand Reinhold, 1991 


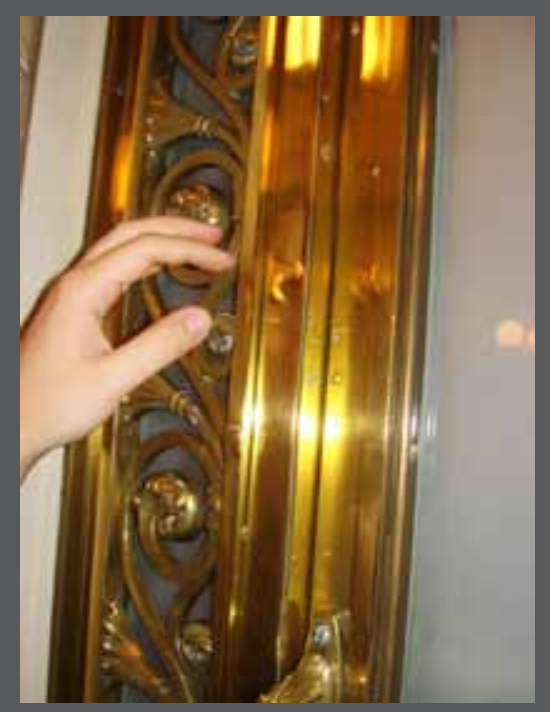

Alexandre, no Centro

Cultural Banco do Brasil
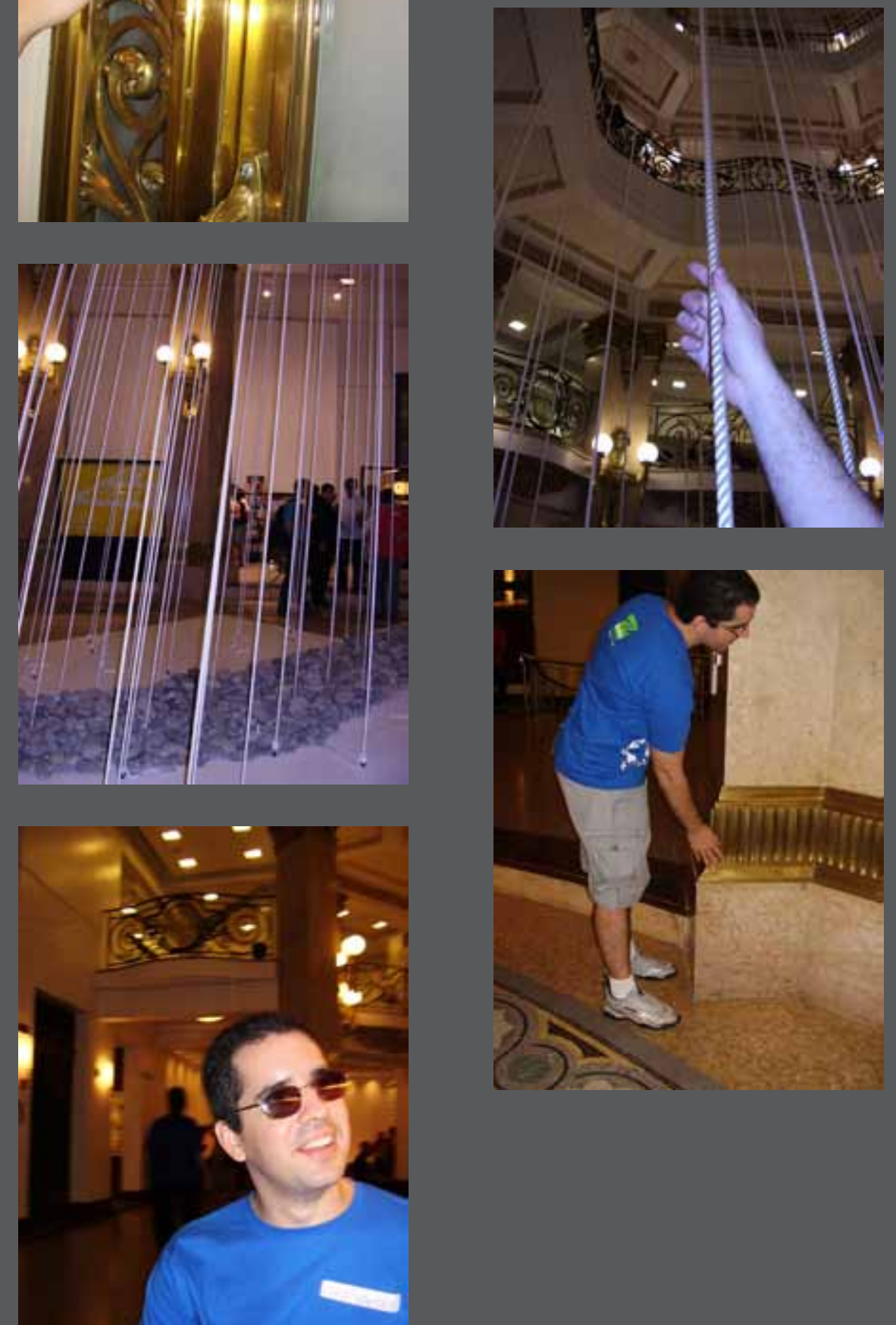
restriçóes resultantes de deficiências como membros de uma família, funcionários, compradores, clientes, inquilinos. Desta maneira, espaços pobremente construídos para pessoas com deficiência podem ser resultados de concepçóes errôneas como:

- Pessoas com deficiência não saem com frequência

- Pessoas com deficiência não querem/precisam de empregos

- Pessoas com deficiência não têm família, marido/mulher, filhos, de maneira que um apartamento de um quarto deve ser suficiente para elas

- Pessoas com deficiência precisam ter acesso apenas a consultórios médicos e outras facilidades da área da saúde

- Pessoas com deficiência desejam ou deveriam morar juntas

- Pessoas com deficiência não são ricas e nem autossuficientes, de maneira que não são parte importante do mercado de consumo (PREISER, 1991, p. 155, tradução minha)

Essas concepçóes resultam em planejamento, desenho e programas empobrecidos e proibitivos para pessoas com problemas de locomoção relacionados à poliomielite, reumatismo, AVC, problemas de baixa visão e cegueira, problemas cognitivos e Alzheimer, surdez, Síndrome de Down, idade avançada e mesmo limitações temporárias como gravidez, fraturas, recuperação cirúrgica que exigem atenção especial. O planejamento requer conhecimento e sensibilidade, pois espaços que recebem bem cadeiras de rodas não são necessariamente confortáveis, por exemplo, para pessoas cegas.

$\mathrm{O}$ autor segue indicando ambientes livres de barreiras, direitos das pessoas, tecnologias desenvolvidas recentemente e outros tópicos de igual interesse. Cita Greer ${ }^{17}$, apontando que embora leis locais e nacionais exijam soluçóes acessíveis, aplicadas em um número crescente de construçôes, os métodos e conceitos geralmente não são ensinados nos programas das universidades de arquitetura, em cursos de design ou paisagismo. Embora esta pesquisa não trate de acessibilidade e desenho universal, a observaçáo crítica de ambientes preparados para receber pessoas com deficiência pode auxiliar na comprovação da hipótese. Espaços acessíveis geralmente transmitem sensaçóes de segurança, induzem à agilidade e liberdade na movimentação e promovem consequente aumento da autoestima, com alteração de atitudes psicológicas e sociais. 


\section{Barreiras físicas e sociais}

Nos depoimentos dos protagonistas aparecem, quase sempre em primeiro lugar, as críticas em relação às condições das nossas calçadas. Buracos, pedras soltas, saliências, remendos malfeitos, tampas de bueiro soltas ou em desnível, postes, lixeiras, toldos, portóes de garagem, vendedores, andaimes, hastes de metal para sinalização, mesas e cadeiras de bares, são alguns dos elementos apontados. ${ }^{18}$ Com frequência aparece também o nosso "orelhão", responsável por vários acidentes, batidas na cabeça, mesmo quando tem sua área demarcada pelo piso tátil. $\mathrm{O}$ piso tátil é questionado por algumas pessoas cegas que se ressentem por ter que "andar em fila", por não ser facilmente detectado, ou ainda quando instalado de maneira inadequada. Um fator auxiliar seriam as calçadas com diferentes acabamentos, como uma faixa de textura diferente junto à guia, comumente encontradas em cidades europeias, assim como também em Buenos Aires e Tel-Aviv.

A composição de diferentes e contrastantes texturas (cimento e paralelepípedo ou cimento e pedra portuguesa, por exemplo) teria efeito estético para pessoas que enxergam e serviria de indicação e orientação sutil, porém muito útil, para pessoas cegas, cuja bengala acusaria as diferentes texturas e facilitaria o caminhar em linha reta ${ }^{19}$.

Pessoas com deficiência visual comentam que não é verdade que estejam amarguradas em casa e por isso não saem, mas, sim, sentem dificuldade de acesso aos locais. Locais abertos, sem nenhuma referência como a Praça da Sé, ou o Memorial da América Latina, ambos em São Paulo, exigem que a pessoa com deficiência visual esteja acompanhada por um vidente que lhe aponte o caminho. Pisos com diferentes texturas, ao contrário, depois de conhecidos, podem direcionar os passos de quem caminha pelo local, orientando pela diferença da superfície.

$\mathrm{Na}$ arquitetura urbanística é preciso tentar entender as pessoas e suas necessidades, criar rotas e serviços pela cidade. Soluçóes de baixo custo podem significar grandes diferenças no cotidiano dos cidadãos cegos. Discretas marcaçóes em guias, ponto de ônibus, painel que reveste a parede de estação de Metrô, podem sinalizar locais e fazer diferença na orientação. Ferragens desenhadas para receber o toque podem significar uma saudaçáo de boas-vindas para todos os ci-

18 A Lei Municipal 15.442 de 09/01/2012 prevê multa mínima de $\mathrm{R} \$ 300,00 / \mathrm{m}^{2}$ para quem não mantém as calçadas em boas condiçóes e livres de obstáculos. O prazo para limpeza e conserto da calçada é de 30 dias, mas de acordo com matéria publicada no jornal O Estado de Sáo Paulo, a lei tem sido ignorada pelos cidadáos: Lei das calçadas é ignorada, apesar da multa alta. Luísa Alcade. O Estado de São Paulo. Caderno Metrópole, 30 de janeiro de 2012, p. C6

19 Sobre calçadas, leia mais em "Contribuiçóes para uma cidade mais amigável". 
dadãos. Além de barreiras físicas, existem as barreiras sociais, de aceitação, de atitude e comportamento dos cidadãos sem deficiências aparentes, na relação com pessoas com deficiência visual. Muitas dessas barreiras podem ser entendidas como preconceito, assunto tratado no capítulo 3. Lobell $^{20}$ apresenta a obra de Louis Kahn, falecido em 1973. O arquiteto usava a palavra "Silêncio" para o que não pode ser mensurado ${ }^{21} \mathrm{e}$ "Luz" para o mensurável. As páginas dividem o texto em prazer, tato e visão, admiração, realização, intuição, o mensurável e o imensurável, conhecimento, ordem, silêncio e luz, singularidade, forma e desenho, lugar, espaço, estrutura, plano, materiais e se referem à arquitetura do espírito. Reflito sobre como esses conceitos podem abrir a minha própria percepçáo durante os passeios que realizo com as pessoas cegas.

20 LOBELL, John. Between silence and light. Boston, MA : Shambhala Publications, 1979

21 O surfista e professor de yoga Elias "Figue" Diel, de Florianópolis, é protagonista do curta-metragem Uma luz no fim do tubo, filme de Antonio Zanella. Elias perdeu a visão em um acidente de carro aos 16 anos. Voltou a praticar o surfe sentindo a pressão da água nos pés e ouvindo as ondas: "silêncio é onde está a parede da onda", diz ele. 


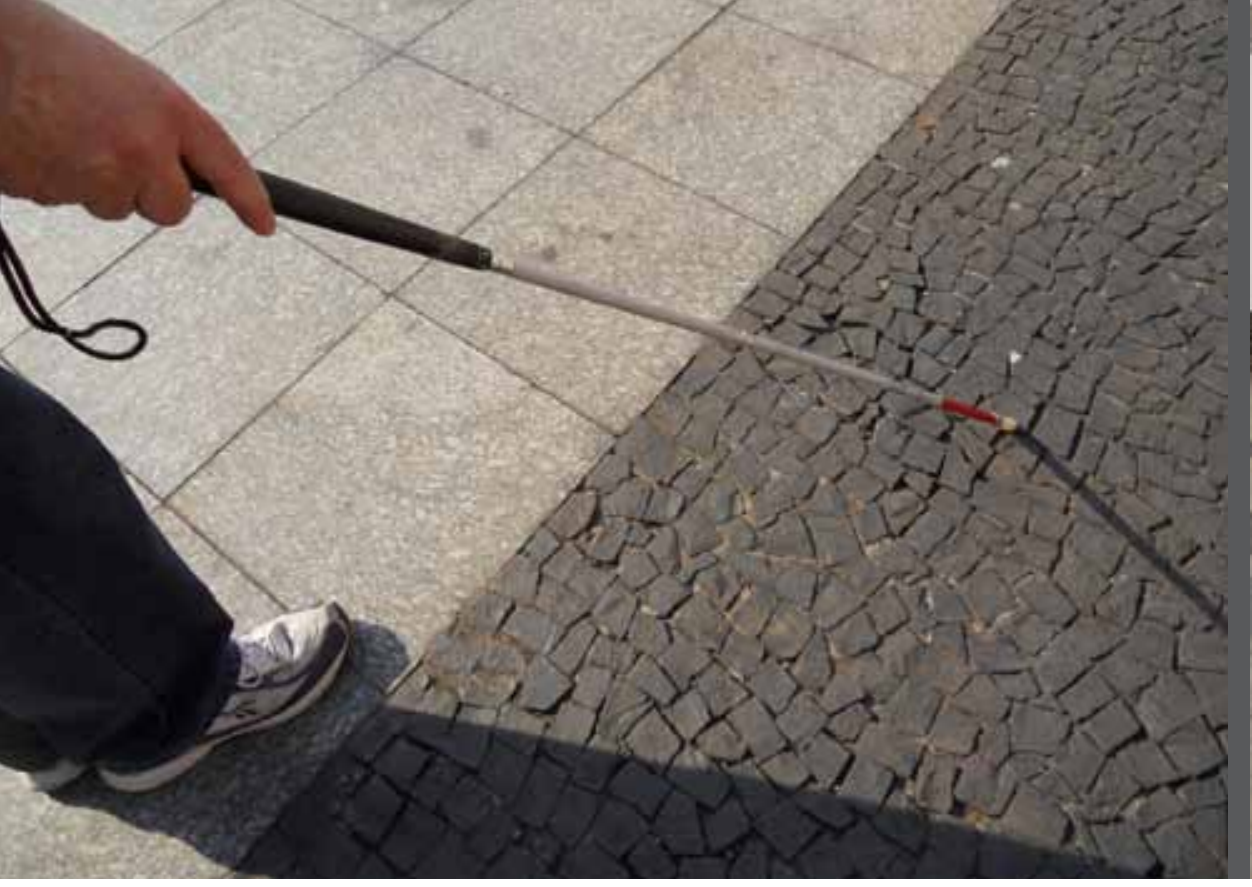

A bengala acusa a diferença de textura e direciona a pessoa, desde que ela já tenha recebido a informação do caminho que a passarela traça.

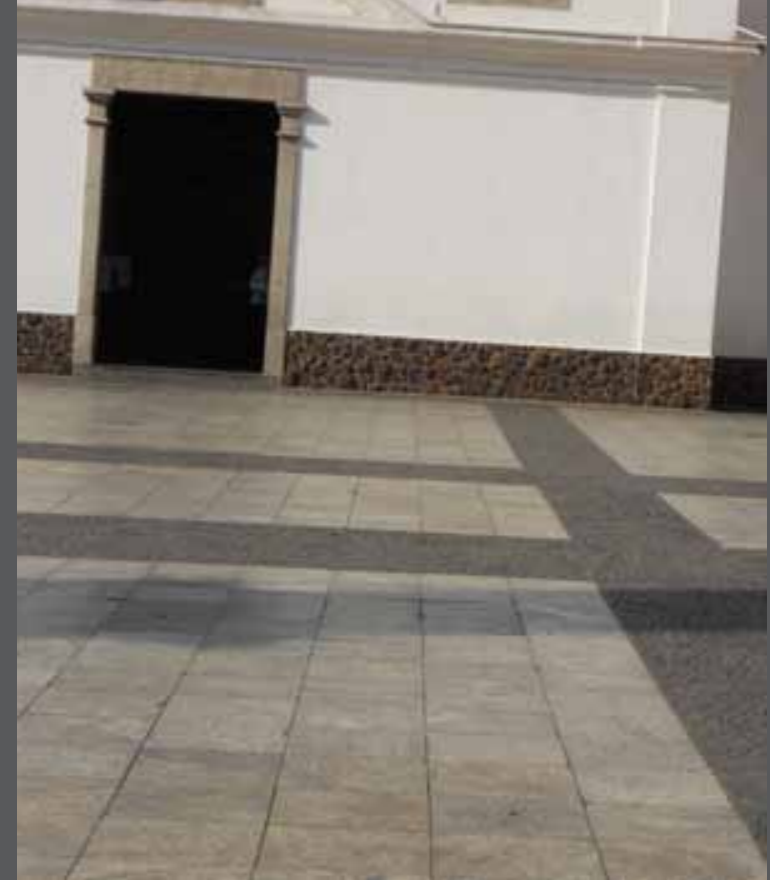

O piso do Pátio do Colégio pode funcionar como piso tátil orientador para pessoas cegas.

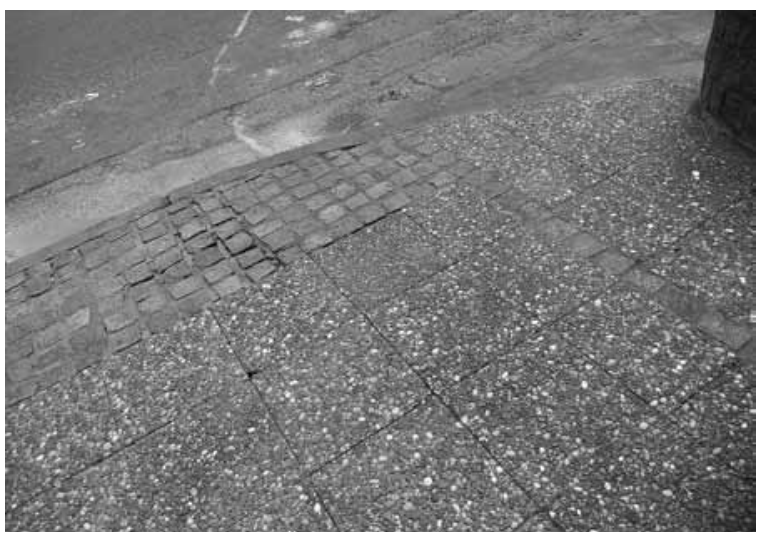

Em Buenos Aires, muitas das calçadas apresentam faixas de piso de diferentes texturas, o que facilita a orientação de pessoas cegas que já conhecem o local.
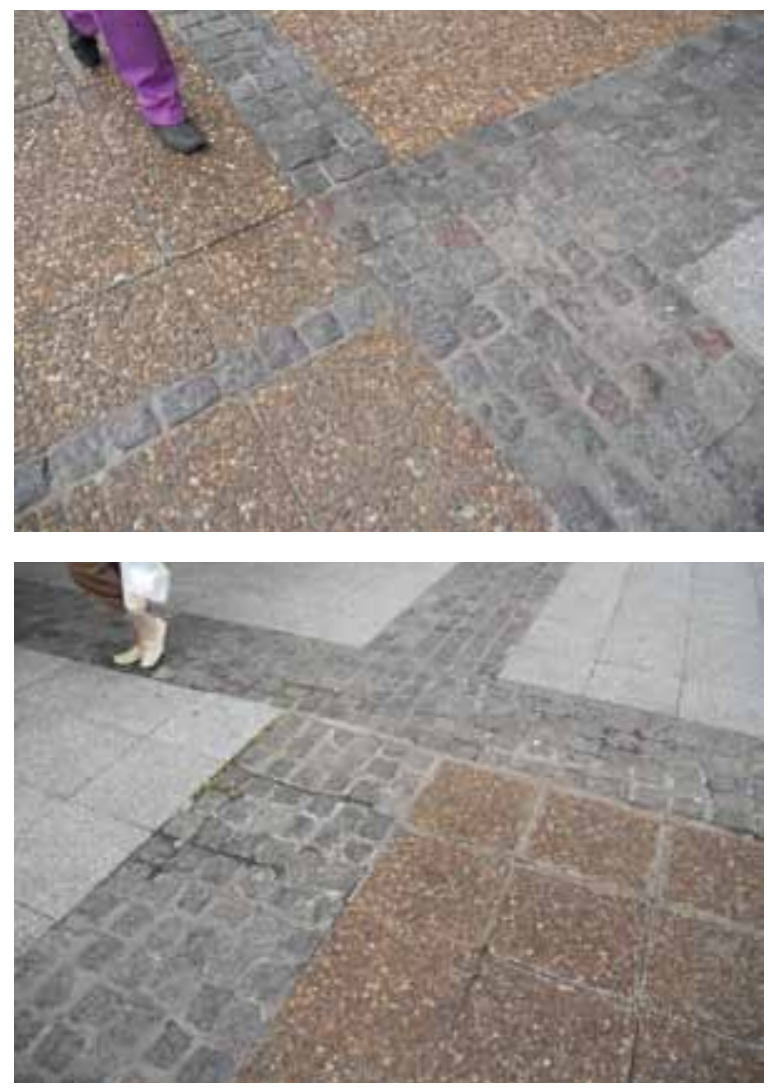


\section{A pele lê a textura}

Ricardo, 59 anos, caminha atento às peculiaridades do percurso, construindo nos seus caminhos a sua paisagem particular. Cidadão paulistano, bibliotecário aposentado, cego desde a infância, faz o percurso de casa para o trabalho de Metrô. Ao sair do trabalho, caminha sozinho em direção à estação Vergueiro, desce as escadas e se dirige à plataforma de embarque. Embora o local seja movimentado, cheio de riscos, ele náo pede ajuda. Caminha junto aos painéis que revestem a parede da plataforma e, ao chegar a um determinado ponto, sabe, pela textura do painel, que quando o trem chegar ele estará exatamente em frente ao primeiro vagáo, que é reservado às pessoas com deficiência. Ricardo faz questão de observar que se trata de uma ousadia que ele não indica para outras pessoas com deficiência.

\section{A nossa cidade está a cada dia mais violenta e a população de usuários do metrô tem aumentado muito. Muitas vezes nem olham por onde andam. Um deficiente visual, ao entrar em uma estação de metrô, deve sempre pedir o auxílio do funcionário que está lá para esta função, é bem seguro e funciona muito bem.}

$\operatorname{Tuan}^{22}$ reflete que a maioria das sensaçóes táteis nos atinge de maneira indireta, pela visão. O nosso entorno físico é inevitavelmente tátil, mesmo que toquemos apenas uma pequena parte dele. Uma mesinha de café de vidro ao lado de uma caixa de madeira polida, é uma composição tátil, lembra o autor. Uma rua de casas revestidas de arenito e bonitas árvores formam uma cena charmosa, mas o charme nos alcança tanto pelo sentido do tato quanto da visão. As sensaçóes da visão e do tato estão de tal maneira unidas que, mesmo quando olhamos uma pintura, não fica claro que estamos atentos apenas às suas qualidades visuais. Classen questiona como seria a vida sem o sentido do tato (CLASSEN, 2005, p. 305).

A pele lê a textura, o peso, a densidade e a temperatura, detecta prazer e sofrimento, conta os anos da história. Da mesma forma, a cidade que construímos se desgasta com o tempo e o uso. Degraus gastos conservam pregnância e contam sobre pessoas que passaram por eles. $\mathrm{O}$ tempo esculpe a sua história nas construçóes, no reboco dos muros, corroendo grades de metal, gravando texturas no cimento das calçadas. A gravidade é medida pela planta dos pés e caminhar pode ser uma maneira de traçar a densidade e textura do solo, indica Pallasmaa (PALLASMAA 2008, p. 58).

O corpo sabe e se lembra, de maneira que significados da arquitetura podem advir de reaçóes

22 TUAN, Yi-Fu. The pleasures of touch. In: CLASSEN, Constance - editor. The book of touch, New York : Berg Publishers, 2005, p. 74, tradução minha. 
memorizadas pelos sentidos. A musculatura mede os degraus, as mãos alcançam os corrimãos, a pele reconhece o cenário. Para Montagu, a pele é o mais antigo e sensível dos nossos órgáos e todos os demais sentidos são extensóes do sentido do tato (MONTAGU, 1986, p. 21-31). Desta maneira, podemos considerar o sistema háptico como um dos mais importantes e fundamentais na percepção que pessoas com deficiência visual têm da paisagem. Segundo Bloomer, o sistema háptico é o sentido do tato reconsiderado para incluir todo o corpo e não apenas a sensibilidade das pontas dos dedos. Este sistema perceptivo engloba as sensações de pressão, temperatura, dor e sinestesia. Este é o único sentido capaz de alterar o meio no processo de percebê-lo, ou seja, une o fazer com o sentir. Podemos ver e ouvir figurativamente e a distância, mas tocamos a coisa presente (BLOOMER, 1977, p. 34).

Se um fenômeno - seja um reflexo ou um sopro de vento - só se oferece a um de meus sentidos, ele é um fantasma, e só se aproximará da existência real se, por acaso, se tornar capaz de falar aos meus outros sentidos, como por exemplo o vento quando é violento e se faz visível na agitação da paisagem. Cézanne dizia que um quadro contém em si até o odor da paisagem. (MERLEAU-PONTY, 1994, p. 427, com citação de Schapp)

Esta colocação me remete às pessoas cegas descrevendo como percebem o vento em sua pele. Hull (1997) relata que durante suas caminhadas pela cidade, há certo ponto em que passa por uma área com vento. Conta que, em um determinado dia, durante o seu passeio matinal, encontrou a vento ao virar uma esquina, um vento perfumado. Sentou-se por um momento, para senti-lo na face e nas roupas. Aprendeu com as correntes do vento, virando a cabeça de um lado para o outro, respirando o vento, sentindo o prazer daquele momento. Pergunta por que o vento tem tanto significado para pessoas cegas. Talvez por ser invisível?

Daniel nos passa a sua percepção do vento e da chuva, no verão de Sáo Paulo.

Estando dentro de casa percebo a chuva e o vento pelos sons que eles produzem, e o som da chuva é mais agradável. Quando venta forte predominam os sons não naturais de partes soltas das construçóes. Já o som produzido pela chuva é mais gostoso. Este som também traz boas recordaçóes da minha infância, quando eu jogava futebol em dias chuvosos. Era muito bom! Gosto do vento quando ele é uma brisa e posso senti-lo mais suavemente.

Para videntes e seu mundo visível, o vento pode ser observado apenas acidentalmente, uma das tantas coisas que se nota ao caminhar em áreas externas. Ou considerado mote poético, como na obra 
de Yeats ${ }^{23}$. No entanto, pessoas cegas que experimentam o impacto do vento em seu corpo percebem sua temperatura, umidade, e o som que faz, sacudindo as árvores; percebem claramente a sua direção, os sons que traz e os objetos e partículas que desloca e carrega consigo.

\section{Paisagem sonora}

Encontramos diversas referências ao uso dos sons na percepção da paisagem das pessoas que enxergam e que não enxergam com os olhos. Temos em Thoreau:

Às vezes, aos domingos, quando o vento estava favorável, ouvia os sinos de Lincon, Acton, Bedford ou Concord, uma suave e doce melodia, como se fosse da natureza, e de grande valor em meio àquele ermo. A uma distância suficiente sobre os bosques, o som adquire certo sussurro vibrante, como se agulhas dos pinheiros no horizonte fossem roçadas feito as cordas de uma harpa. Todo som ouvido a maior distância possível, produz um só efeito, uma vibração de lira universal, exatamente como a atmosfera que nos circunda torna interessante a nossos olhos uma remota aresta de terra, graças ao tom de azul que lhe confere. Neste caso, chegava até mim uma melodia filtrada pelo ar e que havia conversado com todas as folhas e hastes do bosque, aquela porção de som que os elementos apreenderam, modularam e ecoaram de um vale ao outro. (THOREAU, 1984, p. 121)

A capacidade de ouvir os sons e localizá-los no espaço é vital para humanos e animais, aponta Schiffman (2005); orienta a direção do olhar e serve para localizar eventos sonoros. Para pessoas cegas é uma ferramenta fundamental, já que ajuda a detectar obstáculos evitando assim a colisão e os acidentes. Há pessoas que têm facilidade em perceber obstáculos com a ajuda dos sons. Estudos feitos desde 1940 investigam a visão facial ${ }^{24}$, nome dado em 1947 para essa capacidade, atribuída ao rosto.

23 The wind blows out of the gates of the day, / The wind blows over the lonely of heart, / And the lonely of heart is withered away, / While the faeries dance in a place apart, / Shaking their milk-white feet in a ring, / Tossing their milk-arms in the air; / For they hear the wind laugh, and murmur and sing / Of a land where even the old are fair,/ And even the wise are merry of tongue; / But I heard a reed of Coolaney say, / "When the wind has laughed and murmured and sung, / The lonely of heart is withered away!" - William Butler Yeats

Poems of To-Day: First and Second Series. London : Published for the English Association by Sidgwick \& Jackson, Ltd. , 1924.

24 WORSHEL, p. . \& DALLENBACH, K. M. Facial Vision : perception of obstacles by deaf-blind. American Journal of Psichology, 1947, 60, 502-553 apud SCHIFFMAN. 
A ecolocalização também aparece como responsável pela capacidade de detecção de obstáculos por pessoa com deficiência visual e por facilitar a sua própria localização no espaço urbano interno e externo. Griffin ${ }^{25}$ desenvolveu interessante estudo sobre sons feitos por homens e morcegos, refletindo como é possível, com a ajuda dos ecos, se desviarem de obstáculos. Os estudos, desenvolvidos em Cornell University mostram como pessoas cegas e videntes vendadas são capazes de se guiar pelos sons, assim como também se desviar dos obstáculos do caminho. No livro destaco o capítulo: Suppose you were blind (GRIFFIN, 1956, p. 129).

Mais recentemente, experiências semelhantes com ecolocalização têm sido desenvolvidas por $\mathrm{Kish}^{26}$. O pesquisador da California State University, sendo ele próprio uma pessoa cega, compara a percepção de pessoas com deficiência visual com a dos morcegos. Relata estudos sobre a capacidade de perceber pequenos objetos a dois ou três metros de distância e outros trabalhos de pesquisadores como Jones \& Myers (1954). "Para mim, pessoalmente, um dos sentidos-chave é o da ecolocalização. Ele me permite perceber o ambiente a distância, sem que eu necessariamente tenha que tocar tudo para perceber o que é ou onde está. Eu tenho exercitado isso desde que me lembro, portanto é algo que trago comigo desde cedo".

Kish reflete sobre a propriedade física que o som tem de se irradiar linearmente em forma de ondas, a partir da sua origem. Quando um som reverbera, é chamado de eco. Assim como o som, o eco é moldado por propriedades físicas e reflete as características da superfície na qual incide. Por esse motivo, é possível determinar a natureza da superfície que o reflete. Superfícies próximas ou distantes, maiores, menores, lisas e com texturas, retas, curvas, todas têm uma maneira própria de refletir o som e pessoas cegas podem fazer uso desse recurso em seus processos de localização.

O autor descreve detalhadamente a ecolocalização, discorre sobre timbre, reverberação, campo acústico, a natureza do eco, superfície, fontes de som, distância e posição do alvo, percepção da forma, densidade, textura e do tamanho do objeto. Aborda também a interpretação do eco, detalhando timbre, intensidade e envelope, como é chamada a reverberação de uma onda modulada. Sobre a habilidade

25 GRIFFIN, Donald R. Echoes of bats and men. Science Study Series. New York : Anchor Books, Doubleday \& Company, Inc, 1956, tradução minha.

26 KISH, Daniel. Echolocation: how humans can see without sight-Sonic Echolocation: a modern review of the literature. Sobre a instituição: http://www.worldaccessfortheblind.org. World Access for the Blind: http://www.waftb.org/annual-report-2003-6.pdf Daniel Kish explica e demonstra a ecolocalização em: http://www.youtube.com/watch?v=uobuBc2GO0o 
para o uso da ecolocalização, explica, há inúmeros estudos detalhando como humanos podem entender e interpretar diversos graus de sons, em aprendizado passivo ou ativo, enfatizando que não se trata de uma capacidade de apenas alguns privilegiados.

Kish descreve estudo desenvolvido em Helsinki, na Finlândia (JUURMAA,1965) que constatou que de 52 participantes cegos, $87 \%$ demonstraram habilidade para detectar painéis de diferentes formatos, instalados em diferentes distâncias. A pesquisa envolveu pessoas cegas, surdacegas e videntes, todas vendadas, em saláo de aproximadamente $100 \mathrm{~m}^{2}$ com diferentes pisos. Um painel medindo aproximadamente $1,20 \mathrm{~m} \mathrm{X} \mathrm{1,50m} \mathrm{foi} \mathrm{instalado} \mathrm{suspenso} \mathrm{cerca} \mathrm{de} 0,50 \mathrm{~m}$ do piso. Os participantes deveriam indicar o momento em que percebessem o obstáculo e se deter o mais próximo possível do painel sem, no entanto, tocá-lo.

Os participantes aguardaram fora da sala, para onde foram introduzidos aleatoriamente. Pessoas com deficiência visual, calçadas, caminhando sobre piso de madeira, foram capazes de perceber o obstáculo a cerca de oito metros. Participantes sem problemas de visão, depois de algumas tentativas, detectaram o obstáculo a dois metros. Do mesmo modo, pessoas com e sem visão foram capazes de se aproximar até cerca de quinze centímetros do obstáculo sem tocá-lo. Quando a experiência foi repetida com os participantes sem calçado, usando apenas meias, sobre piso de carpete espesso, o desempenho de todos caiu igualmente. A experiência foi repetida com os participantes usando luvas grossas e com o rosto e cabeça enrolados e aí sim o desempenho foi afetado. E novamente eliminando todos os modos de percepção, com exceção da audição, o que não suscitou diferença considerável. Nos experimentos com pessoas surdas, estas foram incapazes de perceber o obstáculo, colidindo com o painel em 100\% das tentativas.

Outros pesquisadores ${ }^{27}$ puderam também estabelecer uma relação evidente entre a audição e a capacidade de detectar obstáculos. As investigaçóes continuam, abrangendo áreas mais específicas, como a habilidade para detectar os ecos. Conforme indica Kish, os ecos são fenômenos conhecidos popularmente como os gritos que ecoam dentro de túneis ou cavernas, mas podem ser percebidos com abrangência muito maior, já que ocorrem em vários graus, de inúmeras maneiras e em diversas circunstâncias e ambientes. O eco usado pelos animais para localização, segundo o autor, foi investigado por pesquisadores como Lee, van der Weel, Hitchcock, Matejowsky e Pettigrew, além do já citado Griffin. Estudos teriam concluído que certas espécies de morcegos usam o eco produzido pelo som emitido por eles próprios para voarem graciosamente e com facilidade desviarem de minúsculos obstáculos.

27 Kish cita, entre outros, Dallenbach e associados da Universidade de Cornell, Cotzin; Supa; Worchel e, em estudos posteriores, Kohler 
As pessoas não apresentam percepção tão acurada quanto os morcegos, porém a capacidade de perceber pequenos objetos a dois ou três metros de distância foi investigada e comprovada por pesquisadores como Jones \& Myers (1954) e o próprio pesquisador Kish. Segundo Kish, em ambientes abertos, é possível detectar a presença de árvores, mobiliário urbano, automóveis estacionados, colunas, pelo fenômeno conhecido como "sombra sonora", motivada pelo silêncio e falta de corrente de ar. As pessoas cegas que desenvolvem essa habilidade percebem com facilidade o início e o fim de muros, paredes e postes.

Kish relata também outros estudos e treinamentos feitos com ecolocalização. Cita Jansson (1989) para quem o processo de movimentação dos cegos pode ser dividido em duas funçóes: andar em direção a algo e andar ao longo de alguma coisa. Andar em direçáo a alguma coisa, explica ele, significa ter que manter a orientação direcionada para um ponto, próximo ou distante, enquanto que andar ao longo é um processo contínuo de controle da locomoção. O autor cita outros estudos de orientação e mobilidade, apontando que eficiência na locomoção significa também segurança. E indica o estudo Echolocation: What it is, and how it can be taught and learned, que pode ser encontrado na California State University, em San Bernardino. Kish possui uma bibliografia extensa sobre o assunto, publicada no final do estudo.

Pessoas cegas são capazes de andar de bicicleta, cavalgar, jogar basquete, guiando-se apenas pela ecolocalização. O futebol também é um jogo bastante praticado por pessoas cegas, com bolas especiais contendo um guizo interno. Apesar da importância atribuída aos sons e da sua presença constante em todas as modalidades, a paisagem sonora urbana tem sido relevada a um papel secundário, quando não esquecida. Mas, o sentido de distância e de espaço não seria um dos predicados da capacidade auditiva? Proust descreve, do seu quarto, a paisagem percebida do lado de fora: "Indagava comigo mesmo que horas seriam; ouvia o silvo dos trens que, ora mais, ora menos afastado e marcando as distâncias como o canto de um pássaro numa floresta, me descrevia extensão do campo deserto [...]” (PROUST, 1972, p. 11).

É assim a audição, para pessoas cegas, uma ferramenta eficaz na percepção da distância e profundidade, de maneira que as crianças com deficiência visual devem, desde os primeiros anos, ser estimuladas a interpretar os sons e permanecer atentas a eles. Cada ambiente tem seu próprio som, cada ação possui um som diferente e, aprendendo a detectá-lo, a pessoa pode perceber a entrada ou saída de alguém no ambiente, a extensáo dos caminhos que levam a outros locais, assim como a relaçáo com os espaços internos e externos.

Constantino $^{28}$, que analisa o impacto sonoro no meio ambiente, comenta que não há uma história dos sons, mas apenas da música, das partituras e gravaçóes. Embora as pessoas e os sons compartilhem os 
mesmos espaços, fazem-no sem o registro desta relação. Não conhecemos, portanto, os sons das cidades antigas, das guerras, da erupção de um vulcão ou mesmo o som existente na nossa própria casa, na nossa infância. Esquecemos que os ambientes urbanos podem e devem ser mais agradáveis e saudáveis e que aperfeiçoar a relação do homem com o ambiente sonoro melhora a qualidade de vida.

Leninha, educadora aposentada, explica como o vento lhe traz os sons:

O vento traz isso para todos nós, mesmo para quem enxerga. O vento traz, de onde ele está soprando, algum som com ele. E este sopro que vem para o nosso ouvido, se ele está com mais força, se é um vento mais forte, ele acaba até nos perturbando. Porque mexe com a nossa sensibilidade, vai acabar irritando. Um vento muito forte acaba te irritando. Agora, se é uma brisa como essa, é uma coisa mais leve, um vento gostoso.

Tuan registra que, embora os olhos consigam informaçóes precisas e detalhadas, somos sensibilizados mais pelo que ouvimos do que vemos: "O som da chuva batendo contra as folhas, o estrondo do trovão, o assobio do vento no capim e o choro angustiado nos excitam com intensidade raramente alcançada pela imagem visual" (TUAN, 1980, p. 10). O autor comenta o fato de frequentemente nos emocionarmos mais com a música do que com a observação de cenários artísticos ou pinturas e atribui o fato à capacidade passiva e receptiva do ouvido, qualidade não pertinente à visão. A percepção do espaço se amplia intensamente por meio da audição que, ao contrário da visão, nos informa sobre o que está distante de nós. Mas, ainda segundo Tuan, "a percepção é uma atividade, um estender-se para o mundo". Os órgãos dos sentidos devem ser ativamente usados para se tornarem eficazes. Identificando as fontes de ruído, aponta Tuan, podemos construir o espaço auditivo.

Se fecharmos os olhos em nossa casa e nos mantivermos atentos, seremos capazes de perceber os sons da vizinhança, uma grande variedade de sons, compondo uma sinfonia urbana interminável: sons de insetos, pássaros, motores, latidos, miados, estalar de madeira, água correndo, comida fritando na panela, panela de pressão, pessoas tossindo, conversando, limpando, arrastando objetos, janelas se abrindo, o sol estalando o telhado, som de chuva, algazarra de crianças. Com os olhos abertos, distraídos que ficamos com os estímulos visuais, esses sons tendem a "desaparecer". Mas, nas primeiras horas da manhã, quando mal acordamos para o mundo e aos poucos, só aos poucos, tomamos consciência da realidade, esses sons se fazem presente, exigindo dos nossos ouvidos que os recebam. Aos poucos temos deixado de perceber a riqueza dos sons e sua qualidade de elemento intrínseco ao nosso cotidiano para enfatizar o mundo das imagens. 
Segundo Bijsterveld ${ }^{29}$, o desenvolvimento tecnológico nos séculos dezenove e vinte alterou drasticamente o meio sonoro da sociedade ocidental. Sons de fábricas, trens, bondes, automóveis, ônibus, motocicletas, avióes, telefones, rádios, furadeiras pneumáticas, compactadores e milhares de sirenes, buzinas, apitos, engrenagens, acompanham os sons de guindastes, músicos de rua, eletrodomésticos, entregadores, gritos de pessoas (BULL; BACK, 2003, p. 166). A autora aponta que a reclamaçáo sobre o ruído faz parte da história e cita Schopenhauer, que em 1851 dizia que o estalido de um chicote podia acabar com um momento de meditação.

Leninha indica o barulho que desorienta:

Dependendo da sonoridade, irrita. Se aquele barulho é um ruido irritante, é uma poluição que irrita, que vem a doer o ouvido, ai se torna uma poluição irritante mesmo. Mas a poluição sonora, se é poluição sonora já não é coisa boa, porque o próprio nome já está dizendo. A gente tenta tolerar, mas quando a gente cai em si vai sentir que aquele barulho estava irritando tanto e no momento que a gente toma consciência de que é aquele barulho, a gente vai dizer: é esse barulho que estava me irritando. Então a gente acaba procurando se afastar; mexe com o humor, tira a gente da direção que a gente está indo, principalmente em se tratando de pessoa com deficiência visual, tem que se orientar no espaço, no momento que a gente está caminhando, está se mobilizando. Então, o barulho excessivo, vamos supor quando eu estou na rua, andando, sozinha, com minha bengala, indo para um ponto de onnibus, então aquele barulho da rua, dos carros, da moto passando, dos carros buzinando, um barulho provocado por outro tipo de coisa, isso ai desorienta muito. É um fator muito grande pra desorientar a minha locomoção porque a gente se perde, de repente ao invés de eu estar indo mais em linha reta eu vou mais pra esquerda, a gente acaba se desorientando.

Rasmussen afirma que a arquitetura pode ser ouvida, pois, embora não produza sons, os recintos reverberam da mesma maneira como refletem a luz. O autor busca nas suas lembranças de infância os sons da passagem abobadada que levava à cidade de Copenhague e comenta o efeito sonoro grandioso e assustador das carroças ou dos soldados marchando sob os arcos. E constata

29 BIJSTERVELD, Karin. The diabolical symphony of the mechanical age. In: BULL, Michael; BACK, Les. Edit. The auditory Culture Reader. Sensory Formations Series. New York : Berg, 2003 
que, inadvertidamente, náo atentamos para os sentidos que contribuem para a nossa percepção da paisagem. Registra que, quando constatamos que um local é frio, a afirmação decorre de algo que sentimos; quando náo gostamos das cores, discordamos do que vemos; e quando percebemos uma acústica "áspera", onde o som reverbera, isto ocorre pelo fato de ouvirmos (RASMUSSEN, 1986, p. 219). Para Thoreau, o eco pode ser um som original, com magia e encantamento, como as vozes dos bosques e das ninfas (THOREAU, 1984, p. 121).

\section{A percepçáo do outro}

O francês Jacques Lusseyran ${ }^{30}$ escritor e professor, nascido em 1924, fala da sua própria experiência como pessoa cega que aprendeu a se manter alerta para melhor vivenciar a paisagem:

Passei por uma experiência maravilhosa que foi a seguinte: uma voz, a voz de uma pessoa, faz com que ela apareça como uma imagem. Quando a voz de uma pessoa me alcança, percebo logo sua figura, seu ritmo e a maioria de suas intençóes. Mesmo as pedras pesam sobre nós à distância, e assim também os contornos das montanhas distantes e a súbita depressão de um lago no fundo de um vale.

Essa comunicaçáo é táo exata que eu, passeando de braço dado com um amigo pelos caminhos dos Alpes, sabia como era a paisagem e, algumas vezes, era capaz de descrevê-la com uma clareza surpreendente. Algumas vezes; sim, apenas algumas vezes. Eu o conseguia quando convocava toda minha atençáo. Permitam-me que diga com toda franqueza: se todos os homens fossem atentos, se encarregassem de sê-lo em todos os momentos de suas vidas, redescobririam o mundo; veriam subitamente que o mundo é inteiramente diferente do que acreditavam que fosse. (LUSSEYRAN, 1983, p. 29)

O autor relata como enfrentou o período de ocupação nazista na França. Na primavera de 1941, aos 17 anos, iniciou a formação de um grupo no movimento de Resistência, chamado Os Voluntários da Liberdade, que chegou a reunir cerca de 600 jovens estudantes em 1943, unindo-se ao Défense de la France. Editavam e publicavam o periódico clandestino O Tigre. Cabia a Lusseyran a liderança do 
grupo e as entrevistas dos candidatos, pois como diziam os seus companheiros, ele podia "ver", melhor do que qualquer um deles, quem merecia confiança e quem se revelaria traidor.

Não tenho certeza de que me teria saído bem sem minha cegueira. Foi o líder cego a quem todos os meus camaradas escolheram e em que acreditavam. Desde a primeira hora, assumi toda a responsabilidade pelo alistamento de novos membros. Cada novo candidato era apresentado a mim, e somente a mim. Eu conversava com ele bastante tempo. Dirigia-lhe aquele olhar especial que a cegueira me ensinara. Era muito mais fácil para mim do que para qualquer outra pessoa despojá-lo de todas as aparências. Sua voz expressava seu interior e, às vezes, o denunciava. Finalmente, me era possível fazer uso daquela vida interior que o destino me forçara a descobrir táo cedo e tấo a fundo. (LUSSEYRAN, 1983, p. 31)

A cidade abriga várias outras cidades, sendo cada uma delas capaz de propiciar diferentes vivências e apreensóes, revelando-se ao cidadão com deficiência visual pela sua própria dimensão de percepção. Assim, pessoas cegas podem desenvolver a percepção do outro pelo tom de sua voz, bastando para tanto que se mantenha atento aos diálogos.

Nesse sentido, Cutsforth (1969, p. 90) relata um fato curioso de um menino de 13 anos, ao sair com o pai para compras. O pai sai com a encomenda de trazer passas sem sementes. Na mercearia, o proprietário pergunta se ele vai querer sem sementes ou vai preferir passas maiores, mas que têm sementes. Ao deixarem a mercearia levando passas sem sementes o filho pergunta ao pai o porquê do dono da mercearia não querer vender passas sem sementes. $\mathrm{O}$ pai não entende assim, mas numa próxima visita à mercearia se lembra do episódio e comenta o fato. O proprietário responde que as passas sem semente eram de uma encomenda recém recebida e já no primeiro pacote vendido tinha recebido uma reclamação acusando presença de traças nas passas. $\mathrm{O}$ menino percebera a inquietação na voz do vendedor, sentimento não detectado pelo pai.

Crianças cegas se utilizam de muitos recursos para se comunicarem por meio dos sons. Nos antigos colégios para educação de crianças com deficiência visual, comunicavam-se estalando língua e dedos, emitindo sons guturais, assobiando com códigos próprios para avisar se havia visitantes ou alunos novos no local. Recursos como caminhar arrastando os pés, bater palmas ou mesmo caminhar mais pesado, além da batida da bengala, são usados para o entendimento e apreensão do ambiente e pessoas cegas podem fazer uso desses recursos nos seus processos de localizaçáo e reconhecimento de espaços. 
Temos um bom exemplo no filme italiano Vermelho como o céu ${ }^{31}$ que conta a história de Mirco, um jovem toscano que perdeu a visáo em um acidente. $\mathrm{O}$ menino passa a viver em um internato para crianças cegas em Gênova, pois naquela época na Itália não era permitido que crianças com deficiências fossem matriculadas na rede regular de ensino. Apaixonado por cinema, ele passa os dias a criar efeitos sonoros com a ajuda de um velho gravador encontrado na escola. O filme é baseado na história de vida de Mirco Mencacci, conhecido editor de som da indústria cinematográfica italiana.

\section{Memórias passageiras}

Pessoas com deficiência fazem uso constante do transporte público e podem ser bons indicadores da qualidade desse serviço. Em uma cidade como São Paulo, os relatos descrevem percursos de ônibus, serviços prestados pelos funcionários nas estaçóes de Metrô, situaçóes de solidariedade e conflito. Rubens descreve os seus percursos pela cidade, com origem no Itaim Paulista, onde mora.

Venho de trem de Guaianases até a Luz, pego o Metrô na Luz sentido Jabaquara e desço aqui na Estação Vergueiro. Moro com minha esposa, Solange, mas venho sozinho, pego a lotação na rua de casa, perto, pois é uma avenida, desço na estação de Guaianases, nova, de trem. O funcionário me embarca, igual aqui. Tudo é conduzido pelo funcionário, eles avisam pelo rádio, um outro desce e vem me pegar. Hoje o perueiro me entregou para o segurança e ai o segurança avisou pelo rádio para o outro que estava na plataforma para me pegar na linha de bloqueio. Ai me coloca dentro do trem e avisa aonde eu vou descer, que é a Luz. Posso embarcar no trem em qualquer vagão, só o Metrô é que tem vagão específico. Vai falando as estaçóes, pelas paradas, pelo tempo que passa, pelo lado das portas que abrem, quando já está chegando. Quando chego em Guaianases eu espero o povo sair, porque tem que fazer baldeação para outro sentido, e para chegar aqui na Luz eu tenho que esperar o povo entrar para eu sair. Ai eu saio e espero o funcionário para me embarcar no Metrô. Ai chega o Metrô, tem um telefone que eles avisam para me pegar na linha de bloqueio na transferência gratuita. Os funcionários, a gente pega amizade, conhece pelo nome. 
Observa a falta de funcionários e o desconhecimento para guiar pessoas cegas dentro das estaçóes de Metrô.

Pra mim, deveria colocar mais funcionários nas estaçôes, na de trem e na de Metrô. Tem que esperar, às vezes bastante. Tem funcionário que sabe levar, outros a gente tem que orientar. Tem uns que pegam a gente pelo braço e vão levando (puxando), tem pessoa que não tem prática, fico incomodado e ai falo: deixa eu pegar o seu braço.

São inúmeros os relatos de pessoas com deficiência visual no transporte público. $\mathrm{O}$ assunto é motivo principal da conversa entre Leninha, Fernando e Angélica, em encontro no centro Cultural São Paulo. Leninha relata que no Metrô a pessoa com deficiência tem necessidade do acompanhamento do funcionário:

Quando é contratado ele costuma ser treinado para atender o deficiente, por exemplo, como fazer com a cadeira de rodas na escada rolante, guia de deficiente visual, tem técnica, o que acontece é que não existe número de funcionários suficiente para atender a demanda. Hoje mesmo, para eu chegar aqui só tive ajuda de usuários. Vim de Vila Madalena, baldeei no Paraiso, peguei outro trem sentido norte para descer aqui na estação Vergueiro. Se tivesse que esperar pelos funcionários para chegar até a saida do Metrô Vergueiro... Quando eu saí do trem na Paraíso, não tinha nenhum funcionário me esperando. A funcionária da estação Vila Madalena que me embarcou, ficou de avisar um funcionário da estação Paraíso para me pegar naquele trem, viajamos só no primeiro carro, segunda porta, esse é o local. Então, ela avisou pelo telefone interno.

Fernando explica como os funcionários costumam dizer:

$Q R U$ de visão posto $S$ ao norte segundo trem - por curiosidade já perguntei.

Angélica comenta:

Às vezes você chega dois trens antes e você está ouvindo "terceiro trem" ainda; mesmo hoje, peguei na Barra Fundo, desci na Sé. Como já ouvi várias vezes chamar funcionário, pede posto 1 via leste, em geral me pegam rapidinho e eu pensei que hoje ia demorar como já são 9h, vou até o chamador. Disquei na SO, depois de 
um tempo uma mulher perguntou tudo bem? Então eu pedi para ela chamar um funcionário e ela chamou, para buscar aqui no posto I (Itaquera) a leste.

Leninha:

Já está abrindo outro concurso no Metrô, estou sabendo, então isso é tudo política, o que acontece você tem que se inscrever e paga uma taxa. Abrem concurso só pra ganhar dinheiro, quantos vão lá e pagam a taxa... Ficam na lista de espera e nunca são chamados. E a gente precisa de funcionários e os funcionários não existem.

Fernando reflete sobre o despreparo com que é atendido:

Tem usuário que quer ajudar a gente, tem boa vontade, mas às vezes nem pergunta para onde a gente vai e leva a gente em sentido contrário, por exemplo, desci na Luz e queria ir para a CPTM, para o trem. O usuário ao invés de me levar para a CPTM me levou para a saída Norte, saida da estação. Tive que voltar a estação inteira com um funcionário, depois de esperar cinco minutos pelo funcionário, para ele me levar. Perdi dois trens.

Angélica tem que insistir para se fazer entender:

Na Barra Funda, no meio da semana a gente desce pelo esquerdo e o pessoal que enxerga, a maioria já vai sempre para o lado direito. Então, eu já desço logo na central e fico, mesmo assim, esperando o funcionário porque o usuário sobe e já coloca você direto na catraca da CPTM. Eu digo, não vou pegar o trem, eu vou sair do metrô, vou descer para o terminal de ônibus, à direita da catraca, e ele saiu pela CPTM, eu disse que não era lá, ele disse é sim, ficou teimando.

Fernando:

Eles falam terminal de ônibus porque na Barra Funda tem o rodoviário, uma vez me deixou no terminal rodoviário achando que eu ia para o Paraná sendo que eu ia pegar ônibus em SP. 
Leninha:

O usuário está só ajudando, não tem nada com isso, então o que a gente tem que fazer é chamar a atenção, ir na Bandeirantes, Jovem Pan, ir na imprensa, botar a boca no trombone. Eu desci do trem na Paraiso, era pra ter um funcionário, porque a moça que me embarcou ficou de avisar. Desci do trem, não tinha ninguém. Fiquei lá, de pé, esperando. Depois chegou um outro trem, um usuário desceu, me viu, perguntou se precisava de ajuda. Eu respondi que estava esperando um funcionário e ele disse que podia me levar. Eu expliquei que precisava pegar outro trem sentido norte, que eu ia para a estação Vergueiro. Ai uma mulher escutou e disse "estou indo pra lá, eu te levo". Vim com essa mulher, embarquei no trem que vem para a Vergueiro. Desci, lógico, não tinha nenhum funcionário porque quem me embarcou foi um usuário. Então a gente corre risco de vida porque o usuário não sabe como conduzir a gente, eles não têm obrigação de saber, eles não são treinados para isso. Sai aqui na Vergueiro, outro usuário me colocou fora da estação, na calçada. Então, gente, como falei para esse rapaz, pra que a gente vota, eles não estão lá para auxiliar o povo, pra nos defender? Então não adianta mais votar em ninguém.

Angélica faz um relato contundente:

Outro dia eu desci, estava acostumada a pegar o ônibus na Caetano de Campos, pegava o ônibus atrás da minha escola, descia no Paraíso, embarcava para a Sé e da Sé para a Marechal. Antes não tinha ônibus para a minha casa na Barra Funda. Chegava na Marechal, tinha que subir para a parte de cima da estação e sair lá para o lado esquerdo, lado da Laramara, que é uma associação muito conhecida. O problema era dentro da estação, assim que eu descia muitas vezes demorava. Teve uma vez que demorou uns 45 minutos. E eu não segui piso tátil nenhum, porque chega num ponto lá, pensei, a linha some, não sei aonde vai. Ai comecei a andar, pensei, vou até a metade, aonde eu sei. Mas não adiantou nada, ninguém apareceu. Não ouvi ninguém chamando pelo alto-falante.

Dai ouvi barulho de chave e percebi que o funcionário estava vindo. Perguntei se ele era funcionário, ele respondeu que sim e reclamou que eu estava saindo do lugar, que eu nem tinha esperado. Respondi: querido, estou aqui há 45 minutos, você quer que eu espere mais? Estava vindo da escola, não tinha lanche, não tinha dinheiro para comprar 
o lanche na escola, ainda estava com fome, ia chegar em casa para esquentar a comida e ainda o ônibus ia demorar mais uma hora e eu aqui 45 minutos na estação. Eram só dois ônibus por hora e se um passava 1:15 o outro só ia passar 1:45. Então eu ia esperar mais o ônibus por causa do funcionário. Ele argumentou que tinha o piso tátil, mas a gente não foi treinado em cada uma das estaçóes para conhecê-las, e cada uma é diferente.

E Leninha completa:

Não adianta ter marcação no piso da Marechal Deodoro, eu não vou atrás da marcação do piso, acho inseguro. Não gosto, o Metrô é muito perigoso, conheço muita gente que já se acidentou por andar sozinho nas estaçóes, o piso tátil não é suficiente. Precisamos de auxilio humano.

O transporte público sempre constituiu campo de conflito para pessoas com deficiência. Sandra relata as memórias dos seus percursos para a escola, nos anos 60. No ônibus, se lembra de um fato ocorrido quando estavam descendo a Rua Ezequiel Ramos.

O meu irmão que estava junto comigo, foi passar na catraca e a descida era tão ingreme e o ônibus corria, virou a catraca duas vezes e o cobrador queria que nós pagássemos duas vezes. Só que como nós vínhamos com o passe escolar contado, nós não pudemos pagar e dissemos que depois nós levaríamos lá na garagem do ônibus, que era mais ou menos próxima da minha casa. E foi o que aconteceu, no dia seguinte minha mäe levou o dinheiro lá na garagem do ônibus. Eles inclusive disseram que não iam aceitar passe e a minha mãe teve que levar em dinheiro. Naquele tempo as pessoas eram honestas, cumpriam a palavra.

O relato é feito com sentimento de dignidade, de quem se orgulha das origens. Segundo Bosi " ${ }^{32}$ do vínculo com o passado se extrai a força para a formaçáo de identidade" (BOSI, 2003, p. 16). Ela continua:

Quando eu estudava à tarde, o ônibus ia vazio e voltava muito cheio, inclusive tinha fila na Praça Clóvis e não tinha privilégio de passar na frente, deficiente, nada disso, então 


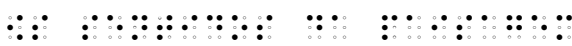

ficava muitas vezes na fila, às vezes tinha que esperar o segundo, ele vinha bem cheio. Isso quando eu estudava à tarde. Quando eu estudava de manhã era o contrário, na ida ia muito cheio, muito mesmo e na volta voltava tranquilo porque era hora do almoço.

Para a professora o ônibus cheio era desagradável, pessoas se alteravam, havia as discussóes dos que queriam ou não passar na catraca, pessoas que entravam por trás e saíam pela frente, sempre superlotada. Quando ainda não havia catraca, o cobrador vinha com um leque de notas dobradas na mão; achava lindo aquele leque de dinheirinho, diz Sandra. E vinha cobrando um por um, às vezes, passava por alguém que dizia já ter pago; pagou, não pagou, a pessoa não achava o bilhete, mostra o bilhete! Todos no ônibus participavam, a menina saía impressionada. O resíduo visual se apropriava do cotidiano de conflitos.

Na capital, os transportes coletivos eram monopólio da Companhia Municipal de Transportes Coletivos - CMTC, cujo principal acionista era a Prefeitura de São Paulo e, dentro de um raio de quatro quilômetros, fazia circular bondes, ônibus elétricos e comuns (Guia do Estado de São Paulo,1962). Os estudantes viajavam com passe escolar e pessoas com deficiência não tinham privilégios. Pessoas com deficiência nos ônibus eram raras, ao contrário de hoje, quando, mesmo que em pequena parcela, saem de casa, estudam, trabalham e reivindicam seus direitos.

Estamos na Rua João Antonio de Oliveira. Sandra explica como era a sua visão naquela época:

Eu tinha um residuo, dava para ver cores, dava pra distinguir onde estava, não sei se era mais pelo que eu via ou pelo que eu deduzia, mas eu tinha uma perfeita noção de onde eu estava, de onde o ônibus parava, eu acho que eram as duas coisas, era um misto de percepção, condicionamento, porque eu já estava condicionada a fazer todo dia o mesmo itinerário e também um residuo visual que também ajudava. Percebia o percurso, onde é que eu estava, pelo sentido que eu uso até hoje, aonde tem as curvas, lombadas, valetas, aonde ele para no semáforo, tudo isso.

Corria o ano de 1959. Sandra morava distante, em relação aos outros alunos e, se havia muito trânsito, a distância parecia ainda maior. Além do incômodo da distância, o excesso de fumaça causava falta de ar, principalmente nas proximidades da Praça Clóvis, quando o ônibus, em fila dupla, demorava a estacionar e liberar os passageiros. São Paulo já sofria congestionamentos naquela época. Nesse sentido, Lefèvre aponta que, em 1960, a situaçáo do trânsito atingiu um nível explosivo, citando a 
participação do coronel Américo Fontenelle e os seus planos para o trânsito das avenidas (LEFÈVRE, 2006, p. 2).

O ônibus de Sandra subia a Avenida Rangel Pestana, tendo, à esquerda, no no. 300, a Secretaria da Fazenda.

Eu achava esse prédio lindissimo, maravilhoso, eu conseguia definir as janelas enormes e $o$ prédio de muitos andares e ai alguém falou que era a Secretaria da Fazenda e que todo o dinheiro do Estado de São Paulo estava lá. Eu achava importantíssimo isso. Um dia eu contei para uma colega de classe que eu passava em frente à Secretaria da Fazenda e ela perguntou: - Mas o que é isso?

- Ah, é um lugar onde fica todo o dinheiro do Estado, onde fazem todos os pagamentos para os funcionários.

E ela não deu a minima importância, e eu fiquei tão decepcionada porque eu achava que era tão chique passar em frente à Secretaria da Fazenda.

Sem nunca ter tocado as janelas do prédio, sem conhecer sua linguagem arquitetônica, Sandra construiu para si uma paisagem interior do que seria o edifício, atribuindo a ele importância e imponência de acordo com os seus valores e a paleta de recursos abstratos que usa para colorir a cidade. $\mathrm{O}$ prédio, reimaginado hoje em sua memória, como ensina Bachelard (1993), conserva os mesmos significados da época em que foi idealizado.

Diferentemente da carteirinha com foto, com a qual se adquiria passes escolares pela metade do preço, hoje um cartão permite percursos gratuitos para Sandra e seu acompanhante. Emprestando a expressão de Ecléa Bosi, nos passeios de cunho etnográfico que faço com pessoas cegas pela metrópole sou ao mesmo tempo sujeito e objeto: sujeito enquanto indago, objeto enquanto ouço e registro a maneira multifacetada como pessoas descreverem suas percepçóes e memórias. Com autoridade e sensibilidade, essas pessoas caminham pela cidade usando todo o seu corpo como instrumento de apreensão e fruição.

Ao longo do percurso, a professora Sandra registrou as mudanças ocorridas nas últimas décadas. Já no início, nas suas observaçóes sobre transporte público, surgem latentes as conquistas da inclusão e da acessibilidade que tornaram mais amenas as jornadas das pessoas com deficiência. Quando relata o fato ocorrido com o seu irmáo, que inadvertidamente virou duas vezes a catraca do ônibus, comenta como naquele tempo as pessoas eram corretas, cumpriam com a palavra empenhada. Esta observação traz subjacente uma constatação de mudança de atitude, colocando em cheque a moral e o comportamento dos cidadãos de hoje em relação aos antigos moradores da cidade. 
Sobre o simbolismo atribuído a diferentes áreas da cidade, inicia conferindo importância ao prédio da Secretaria da Fazenda, a partir da informação de que todo o dinheiro do Estado era guardado ali. Passar defronte a um local de tal importância era "chique", na concepção da menina que, mesmo sem nunca ter enxergado o edifício ou conhecido a obra de Ramos de Azevedo, imputava ao prédio adjetivos de importância e magnificência. O deleite e admiração foram construídos a partir da convivência diária e, na interface entre o real e o simbólico, o prédio passa a abrigar vários prédios, como em Proust, o real e o imaginário. A decepção vem da constatação de que a amiga não compartilha com ela o afeto pelo lugar.

\section{Domingo no parque}

Fernando expressa o seu desejo de visitar um parque:

Quero conhecer o Ibirapuera, ouvi de uma pessoa vidente que é bom e que você esquece da vida lá, que dá para passear.

Leninha explica:

Para o deficiente visual curtir o Ibirapuera, precisa de uma pessoa acompanhando, porque sozinho ou em grupo deficiente visual não tem condição nenhuma. Lá não tem marcação nenhuma. E mesmo se tivesse, acho que não é o suficiente, não basta passar o pé e andar, você tem que saber como é a paisagem, alguém tem que descrever para a gente poder curtir toda a natureza, não é só o chão que está marcado e andar a esmo... Narrando, aqui tem um gramado bonito, aqui tem uma flor... O importante é o deficiente visual fazer uma passeio com monitoria, sem monitor é difícil curtir o passeio.

No parque que visito com Leninha não se ouve o ruído da cidade. Nessa caminhada, aprendo a perceber cada elemento da natureza de maneira especial, atribuindo a ela valores de temperatura, textura, dimensão, odor, prazer e desagrado. $\mathrm{O}$ tato registra o que os olhos não enxergam, a memória tece conexôes e as observaçóes brotam conforme vivenciamos a topografia, subindo e descendo pelos caminhos de terra, em jornada revigorante para todos os sentidos.

Leninha, 60 anos, celebra o prazer de um percurso realizado. Com alegria quase infantil, percebe 
a paisagem tocando folhas, troncos, musgos, estabelecendo entre eles comparaçóes lúdicas. Sobe nas árvores, se volta para a direção do vento, pondera sobre temperatura, umidade, dimensóes, topografia.

É um caminho bem largo, irregular, com algumas pedras. Que

delícia pisar na terra, tão diferente da cidade.

Paramos próximo a uma árvore para explorar a textura do seu tronco:

É um tronco peludo, cheio de linhas horizontais. O que é isso (teia de aranha)?

Sobre um cipó dependurado na árvore:

Parece chocolate crocante, cascudo; por que ele é tão cascudo e o broto que sai dele é liso? Nasce fininho na terra, sobe, dá um broto, vai se enrolando e engrossa!

Identificamos uma Paineira (Chorisia speciosa), que Leninha não conhecia, e falamos sobre suas dimensões em relação à escala humana. Em seguida passamos por uma área de bambus. Tomamos uma trilha e entramos no denso bambuzal, tropeçando em troncos apodrecidos, caídos no chão. Encontramos uma sensação diferente, de aconchego, em relação aos espaços abertos pelos quais caminhávamos. Diferença no perfume e no som, que é mais íntimo, mais macio e afável; é quase possível estabelecer comparaçóes com o ambiente de uma sala acarpetada. Os bambus balançam e rangem ao vento. Não se enxerga distante, não se ouve sons vindos de fora. A sensação é de acolhimento. Leninha observa que o broto do bambu é lisinho, parece papel.

Saímos do bambuzal para uma área de eucaliptos (Eucalyptus Citriodoras).

Adoro o perfume do eucalipto, as folhas são muito boas para inalação. Vamos levar um galho?

Abraça o tronco da árvore.

Que árvore fresquinha, gostosa, dá vontade de ficar encostada nela, o tronco é geladinho.

Encosta o rosto. 
Ela é carinhosa e tem a pele lisinha, parece encerada.

Notando pequenas depressóes no troco, comenta:

Olha os buracos do tronco, parece muito com aqueles buracos que as pessoas têm no queixo; agora eu me lembrei do meu pai, quando eu era pequena adorava ficar pondo o dedo no buraquinho que ele tinha no queixo.

A percepção que pessoas cegas têm da paisagem provém da leitura que podem fazer com sua intuição, pele, aparelho auditivo, olfativo, memória, afeto pelo lugar. Participam igualmente dessa apreensão as leituras providas pela imaginação, memórias e emoções. Os sentidos podem deixar sua condição de meros receptores passivos para se tornarem mecanismos agressivos, mas podem também ter significado mais amplo, como na Antroposofia de Rudolf Steiner, quando são considerados também: o sentido da vida, do movimento, do equilíbrio, da temperatura, da fala, do pensar e do eu, além dos cinco comumente adotados, olfato, paladar, audição, visão e tato, perfazendo um total de 12 sentidos.

Leninha tem prazer em abraçar as árvores e percebe que elas têm temperaturas diferentes. As que ficaram expostas ao sol estão mais quentes; outras, aonde o sol ainda não chegou, estão geladas. Os olhos, em rápida varredura da paisagem, não percebem determinadas particularidades. A temperatura é percebida com o toque das máos, os abraços, o encostar do rosto no tronco. $\mathrm{O}$ corpo sente.

Aqui já é um ambiente aberto, porém sombrio. Eu sei porque sinto o frescor. Quando há sol eu sinto que ele toca a minha pele e esquenta. Mas não é só o calor na pele, é um ambiente mais quente, no geral. Estamos pisando num gramado? O piso está fofinho.

Leninha refere-se ao relvado, ao mulch. Abaixa-se para sentir e identificar a relva sob seus pés. Percebe com facilidade tufos de plantas minúsculas, quase imperceptíveis ao olhar e comenta: dá pena saber que estamos pisando e amassando as plantinhas. Identifica a flor da Tiririca (Cyperus Rotundus), com menos de um centímetro de diâmetro e comenta que essa florzinha dá sempre em canteiros.

Identificamos um Guapuruvu (Schizolobium parahyba): O troco é menos gelado do que o do eucalipto!

E um Pau-Jacaré (Piptadenia gonoacantha): Parece papel, mas quase corta como uma lâmina. E a folha parece samambaia-rendeira. 

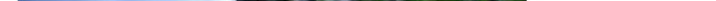

Visita ao Parque CEMUCAM de Cotia, São Paulo 
Um Manacá-da-Serra (Tibouchina mutabilis): As folhas têm pelinhos, parece de lã.

E ainda a Pariparoba (Pothomorphe umbellata): É uma folha grossa, ovalada, sem cheiro, um galho só tem várias folhas

Encontramos sementes no Capim-Gordura (Melinis minutiflora): Quando a gente era criança, colocava o raminho na boca do outro e puxava. Logo a boca ficava cheia de sementes...

Chegamos a uma área aberta, onde um Pinus (Pinus elliotti) de quase um metro de altura cresce no centro:

Que coisa linda, adorei, é pontudo, a folha chega a espetar, chega a doer. E quando cresce a folh a continua assim? É muito lindo, bom para fazer arranjos. E quando seca e cai, como fica? (encontramos no chão alguns galhos secos caidos de outra árvore).

A área aberta é demarcada, de um lado, por uma mureta antiga. Sentamo-nos para um breve descanso e aproveitamos para sentir as samambaias e musgos que crescem espontaneamente nas frestas da alvenaria.

A folha da samambaia de um lado é lisinha, mas embaixo é cheia de saliências. O musgo peludo parece barba.

Quando anuncio a proximidade de uma árvore, Leninha explica:

Olha, antes de você falar que ela estava a um metro, meio metro, eu já tinha percebido, através da percepção mesmo, né? Ela me transmitiu, o tronco da árvore me transmitiu que na minha frente havia alguma coisa. Pelo vácuo, ela quebrou o vácuo. Por exemplo, é aquela corrente de ar, você entendeu? Pela corrente de ar que ela quebrou. Entáo eu sinto que, se eu for para frente, eu vou bater em qualquer coisa. Eu não sei se é árvore, se é poste, se é gente, não sei o que é, mas aqui eu concluo que seja uma árvore porque a gente está perto de árvores, está num ambiente....tem a ver com o vento... Eu não vou falar para você: aqui tem um negócio porque parou o vento, não é isso.

Desviamos dois passos para a esquerda da árvore, que tem um tronco de aproximadamente $0,60 \mathrm{~m}$ de diâmetro. 

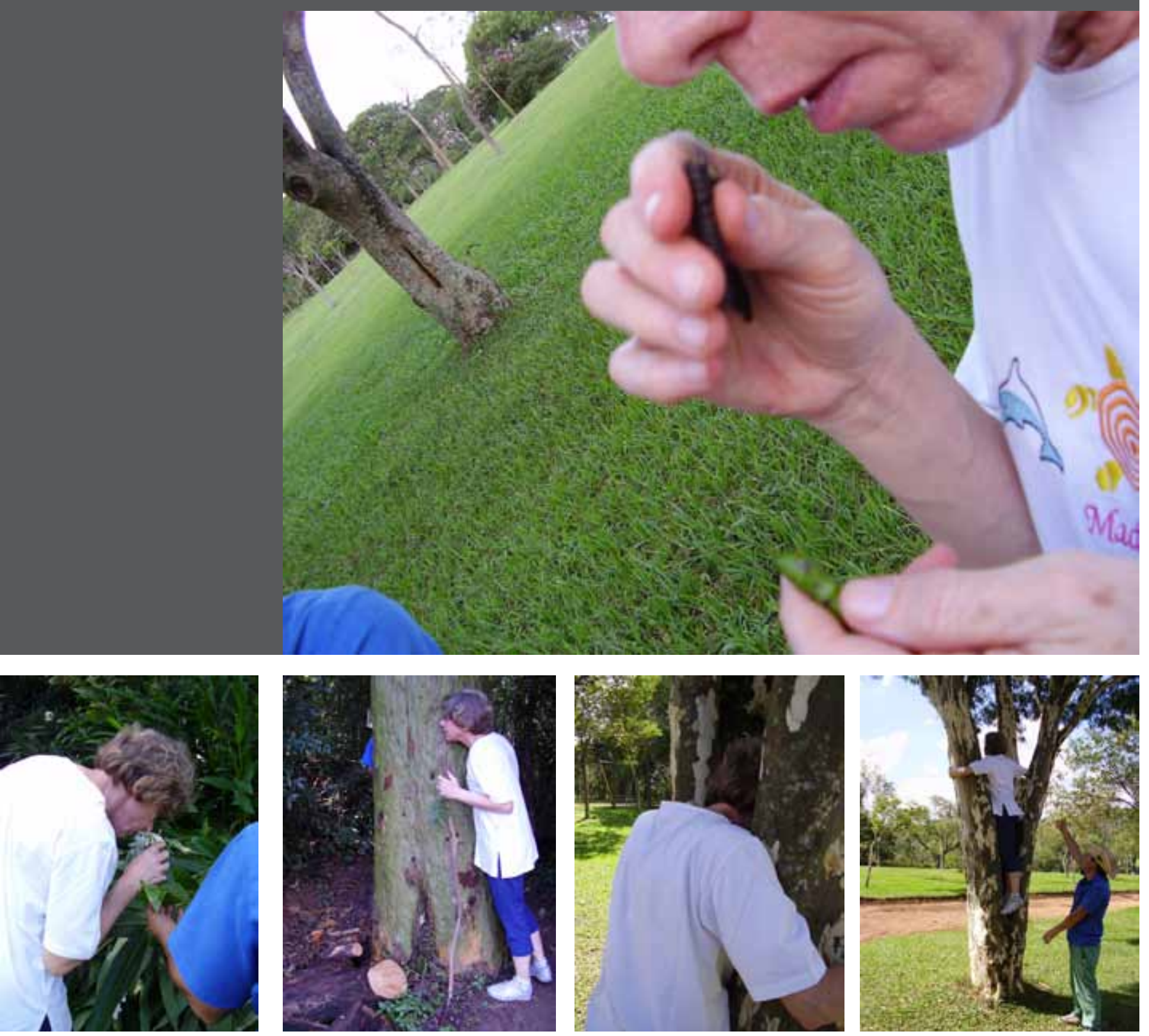

Leninha no Parque CEMUCAM 
Aqui é espaço aberto, espaço aberto que a corrente de ar, no caso, não é nem o vento, é a própria corrente de ar, eu não enxergo, mas dá para perceber alguma coisa assim como se fosse um vulto, entendeu? Se eu virar de costas para o tronco da árvore, na minha frente estou com o espaço livre, agora eu virando de frente para o troco da árvore, eu vou sentir que esse espaço já não está mais livre, né? É a própria percepção. Eu não vou conseguir falar para você o porquê da percepção, porque a gente percebe num todo. Quer dizer, o ar que ficou bloqueado, a corrente de ar que ficou bloqueada, é lógico que ela foi bloqueada por alguma coisa, uma coisa concreta, grande, que chegou a bloquear a corrente de ar. E entáo é isso, se você para diante de mim, eu vou perceber que tem uma pessoa na minha frente.

Saímos detrás da árvore.

Eu me afastei do tronco da árvore. E aqui, nesse pedaço que eu estou pisando, ela é mais fofinha (fora das raizes da árvore). Dá para perceber que a grama aqui está mais crescida, o volume dela aumentou. Não sei se você percebe a mesma coisa. Eu estou com a cabeça erguida, de frente para o sol, e sinto o sol batendo no meu rosto. Em cima dos meus olhos.

Leninha se vira de costas para o sol.

Estou virada, de costas para o sol, e o que bate agora no meu rosto é a própria sombra da minha cabeça; então o meu rosto está protegido do sol. O sol está batendo nas minhas costas e então eu sinto, eu tenho a sensaçáo do sol pelo calor que ele transmite.

E caminha para outra Paineira.

Esse tronco é mais volumoso... Já tem galhos de árvore e tem uma árvore na minha frente (percebe a árvore a aproximadamente 0,80m de distância dela). E ela tem o tronco bem maior que as outras lá de trás. Quanto maior o obstáculo, maior a percepção. Vamos supor, se fosse um poste fino eu não ia ter a mesma percepção desse tronco, que tem todo esse diâmetro.

Depois de duas horas de exploraçóes sensoriais, de pesquisas de sons, odores e texturas, iniciamos o caminho de volta. Caminhamos por outra estrada que também nos leva de volta ao estacionamento. 


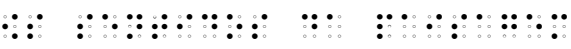

Esta, por sua vez, é ladeada por uma mureta que separa a estrada da área de lazer, onde estão as mesas de madeira e as churrasqueiras de alvenaria, mobiliário muito usado nos fins de semana.

\title{
A estrada é meio curva? Estou sentindo que ela vai se curvando.
}

A constatação surpreende, considerando-se que nós nos encontramos ainda em um trecho reto e a curva só se iniciaria alguns metros à frente. Leninha intuiu a curva da estrada.

\section{Visita ao Parque Trianon - Sáo Paulo}

\author{
Ouvir o barulho das crianças \\ brincando no parquinho \\ infantil é a minha forma de \\ enxergar o parque.
}

Paulo, 44 anos

O Parque Trianon é um refúgio na agitada Avenida Paulista. Possui em seu interior, além de reserva remanescente de Mata Atlântica, outros atrativos como esculturas, viveiro de aves, fonte, chafariz, locais de recreação infantil. A visita de três horas foi feita em fevereiro de 2010 com sete pessoas cegas e sete guias videntes. O biólogo Vitor Lucato e duas estagiárias da Secretaria Municipal do Verde e do Meio Ambiente participaram do passeio, revelando as características do local, da flora e fauna do parque. Tivemos também a companhia da fotógrafa Heloísa Bortz que, voluntariamente, registrou as imagens.

Iniciamos com a apresentação dos presentes, a formação das duplas e a distribuição de saquinhos de tecido com lanche etiquetado em braille. O professor Vitor Lucato fez um breve relato da história do parque e iniciamos a caminhada, com a apresentaçáo das árvores, uma a uma, conforme delas nos aproximávamos: Pouteria (Pouteria macrophylla), Sapucaia (Lecythis pisonis Camb), Vinhático (Plathymenia foliosa), Palmeira-de-leque (Livistona chinensis), Figueira (Ficus carica L.), Alecrim-de-Campinas (Eugenia uniflora), entre outras.

Discutimos características e nomes científicos; estabelecemos comparaçôes de hábitos, tamanhos de sementes, visitaçáo de pássaros. Experimentamos as texturas, sentimos o cheiro, percebemos a umidade, contamos os anéis, abraçamos as árvores, conferindo suas cicatrizes e brotaçóes. Nada escapou às mãos ávi- 
das de conhecimento. A paisagista Marlene facilitou a auscultação do tronco das árvores com um estetoscópio. Testamos diferentes árvores e concluímos que nas de casca mais fina, o ruído do movimento da seiva é mais perceptível.

Mario mostrou-se interessado nas bases das árvores, conferindo suas raízes e a maneira como elas brotam do solo. Paulo, ao contrário, interessou-se pelos troncos e várias vezes esticou o braço para o alto, investigando o seu crescimento. Ouvimos vozes de crianças brincando nas proximidades, o que encantou Paulo. Chegamos em frente à estátua de mármore de Aretusa, obra de Francisco Leopoldo da Silva. Organizamo-nos para a experiência do tato:

Paulo: Olha, Mario, como os músculos da perna aqui atrás estäo bem definidos. Acho que é coisa de caçadora.

Mas Mario parecia mais interessado na base quadrada de granito, investigando, como fez com as árvores, a fixação do objeto no solo.

Paulo: para vocês que enxergam, ela é meio saradinha, não é? Musculosa... Nossa, ela tem batata da perna, correu mesmo (referindo-se à história da ninfa que,

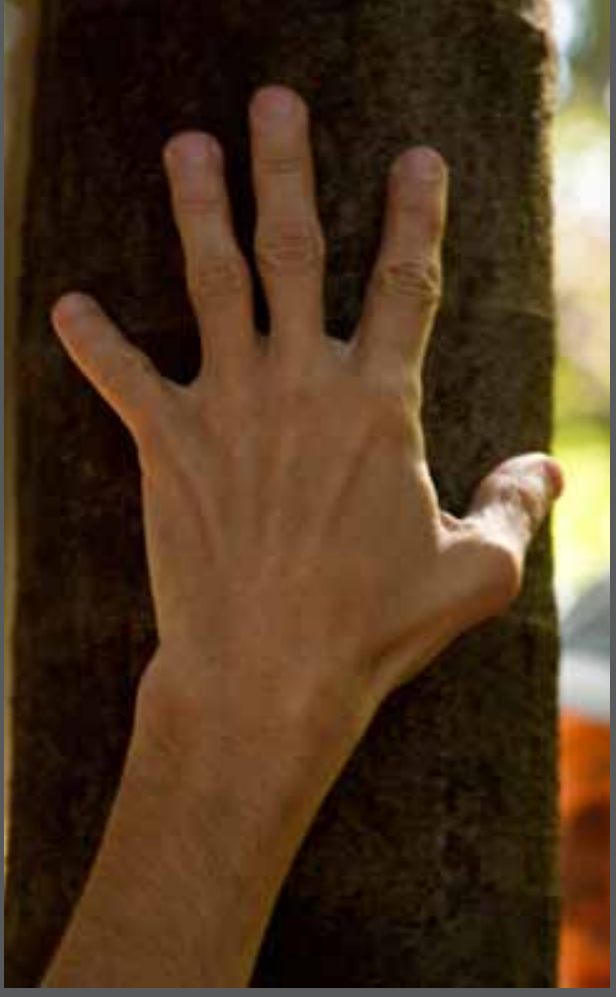

"Eles têm mãos lindas!" Heloísa Bortz - fotógrafa na Grécia antiga, fugiu correndo de um caçador). Braço esquerdo para trás, braço direito dobrado, com a mão na nuca, Paulo reproduz com o próprio corpo a posição dos braços da estátua. Continuando a caminhada, encontramos cipós retorcidos e um exemplar de Pau-Ferro de mais de 200 anos. O professor Lucato explica que, preservada, a espécie pode durar muitos séculos mais. Muitas das pessoas que visitam os parques, no entanto, gostam de gravar os seus nomes nas cascas, o que traz prejuízo às árvores.

Mais adiante temos oportunidade de examinar nervuras de folhas de Curcúligo (Curculigo capitulata) e de Palmeira Jerivá (Syagrus romanzoffiana). Pergunto se descobriram coisas interessantes no Curcúligo. Quem responde é a fotógrafa Helô, que se encanta com os dedos ágeis das pessoas cegas tateando as reentrâncias e saliências das folhas:

- Descobri que eles têm mãos lindas! 
Encontramos um exemplar de Vinhático, (Plathymenia foliosa), que resolvemos abraçar. O professor Lucato expõe que a árvore, antigamente comum na região de São Paulo até o Rio de Janeiro, está extinta pelo motivo da madeira ter sido muito utilizada na fabricação de bancos e portas de igreja. Madeira vermelha, muito apreciada para o mobiliário.

Examinando as palmeiras, Mario pergunta se a irregularidade do caule é natural, ou se foi causada por ferimentos:

\section{- Isso é estrago ou é dela mesmo?}

E Paulo completa:

- Nossa, ela está muito cheia de buracos!
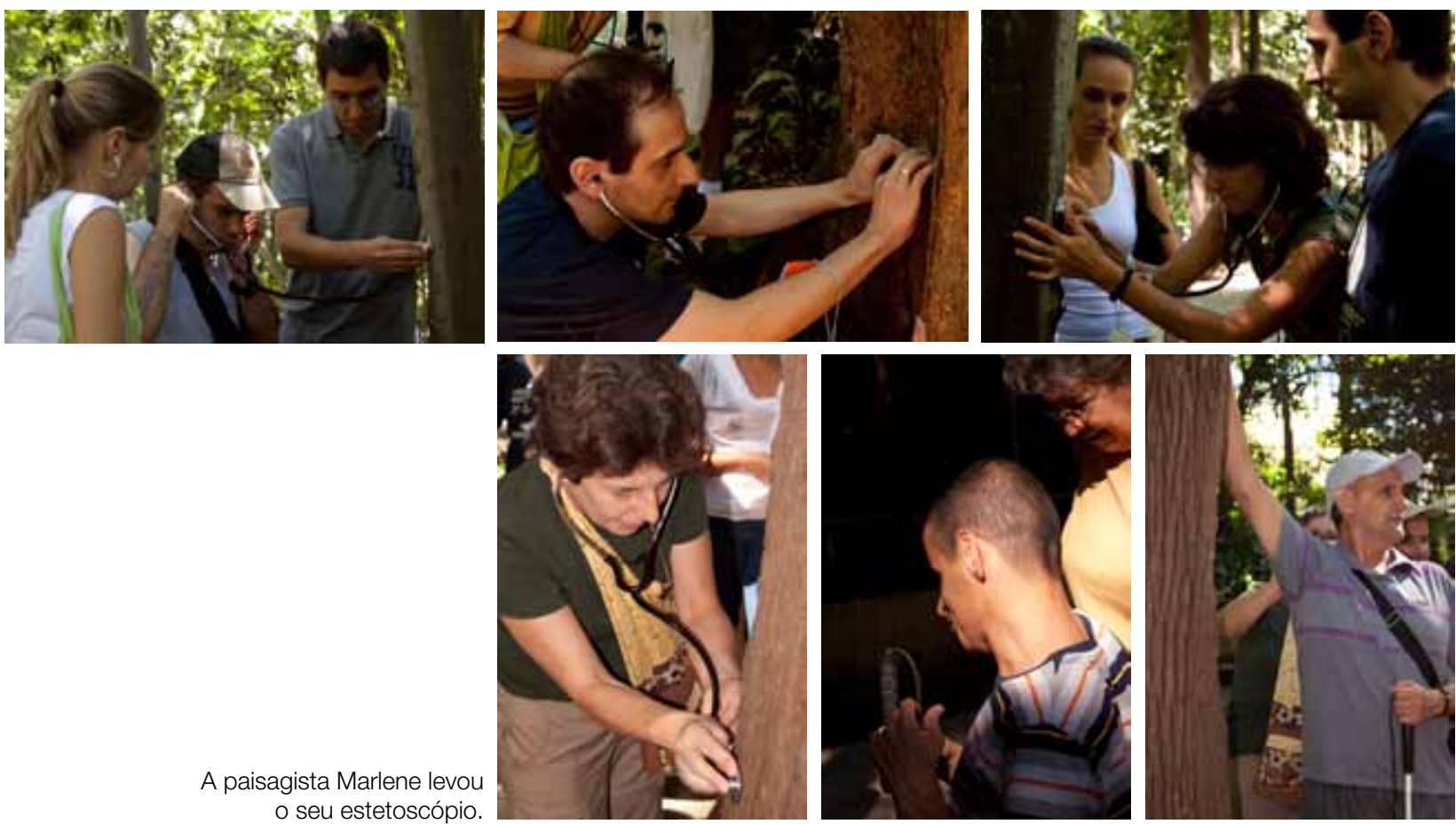

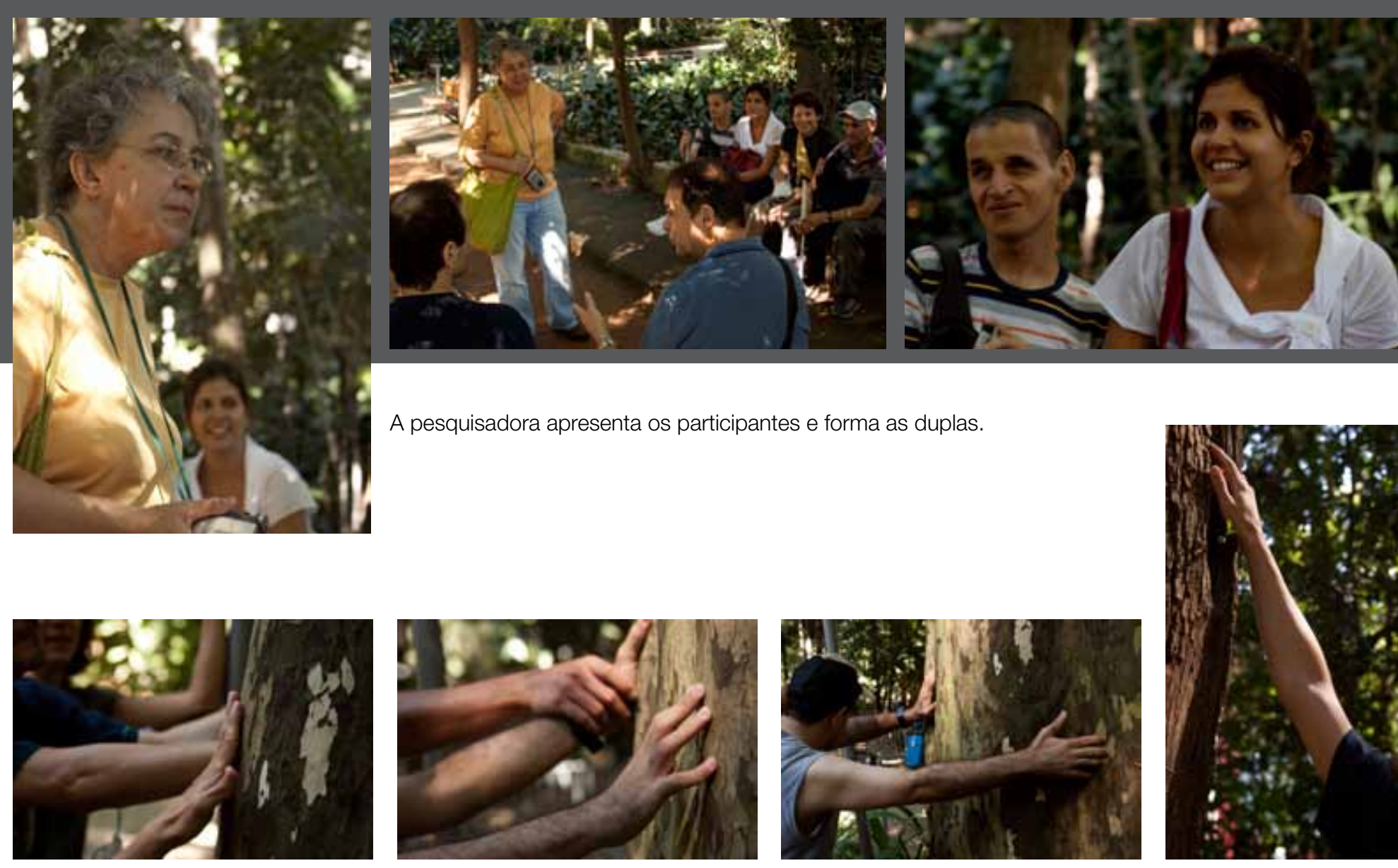

Nada escapou às mãos ávidas de conhecimento.
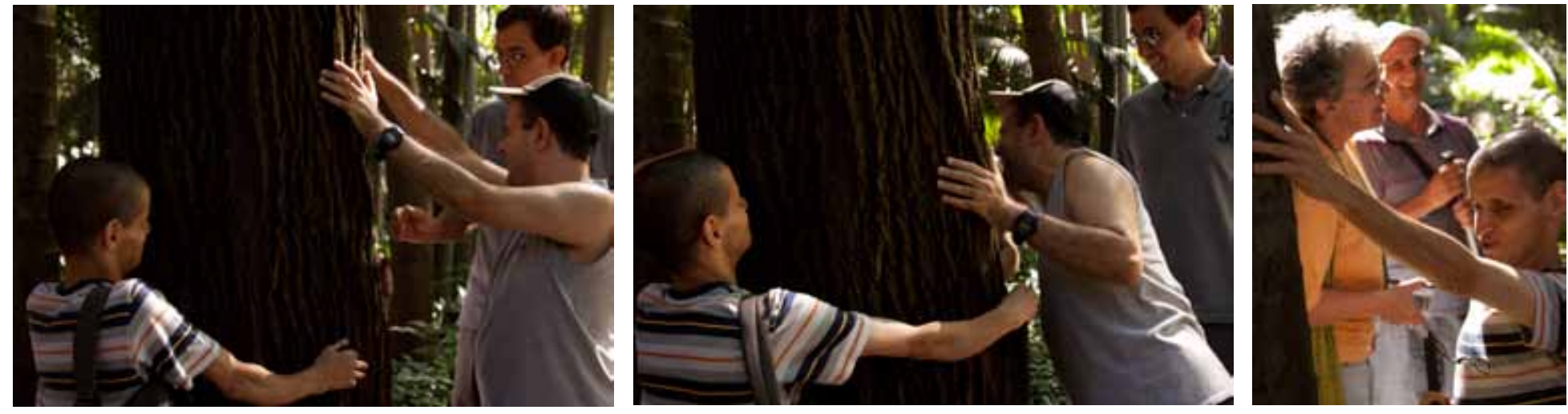

Resolvemos abraçar a árvore.

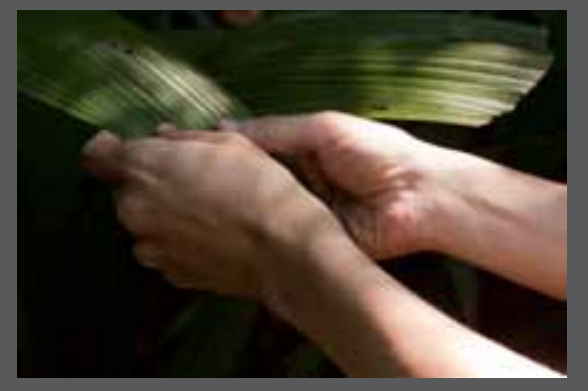

Mario examinando as folhas do curcúligo.
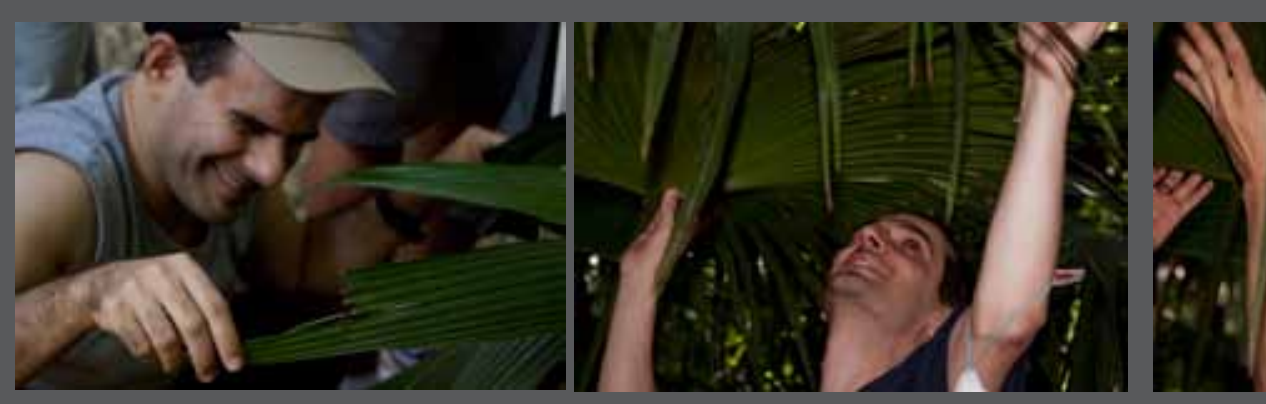

Próximo de nós há uma espécie de Palmeira-de-Leque. 
Conversamos sobre preservação, assim como a importância do plantio de espécies. Vicente preocupa-se com a explicação do professor sobre a importância de plantas com diferentes DNA e a necessidade de coleta de sementes em locais diversos.

\section{- Existe onde pegar sementes?}

O Professor Lucato explica que as sementes são coletadas em florestas e acentua a importância da ação, estimulando o plantio das espécies. Continuando a caminhada, encontramos uma vagem, pela qual todos se interessam. Ouvimos a explicação sobre a identificação da leguminosa e onde se encaixam as sementes. Paramos para investigar a sua forma, textura, peso, densidade, temperatura.

Professor Lucato chama a atenção para a diferença dos troncos do Cedro (Cedrela fissilis), e do Araribá (Centrolobium tomentosum). Fala sobre as partes vivas e as partes mortas de uma árvore, como elas crescem e são podadas nas áreas urbanas, sobre a qualidade do solo e sobre a topografia que determina o crescimento das espécies e as sustenta nas cidades.

Eu me recordo de Gibson que, descrevendo a natureza, aponta que o ambiente terrestre sólido consiste de matéria em estado sólido, é acidentado, é estruturado por colinas e montanhas em escala de quilômetros; é estruturado por árvores e outras vegetaçóes em escala de metros; é estruturado adicionalmente com todo tipo de coisas como pedras, galhos, gravetos em escala de centímetros; e ainda texturizado por cristais e células vegetais em escala de milímetros. Resumindo, tem estrutura em todos os níveis de tamanhos. (GIBSON, 1966, p. 08)

Nas caminhadas com os protagonistas pelos parques, sigo registrando a percepção que têm da vegetação, das texturas, das escalas, do vento, dos odores e sons. Temos em Dufrenne ${ }^{33}$ :

[...] o espaço da paisagem permanece um espaço real que solicita o corpo, uma promessa ou um desafio, um espaço que os ventos e os pássaros percorrem e onde as rotas são um convite à viagem. [...] No prazer que eu sinto numa paisagem, do alto do cume de uma montanha, acaso posso dizer que parte cabe ao frescor do ar, ao perfume das flores silvestres, à satisfação de ter galgado a montanha e afirmado, nessa jornada, minha vontade de domínio? (DUFRENNE, 1972, p. 62) 
$\mathrm{Na}$ textura do tapete verde vivo do chão, Leninha identificou pequeninas flores que já conhecia. Estendeu o braço no alto para perceber a escala do arbusto, testou espinhos, bambus, gravetos, sentiu o vento batendo em seu rosto nas áreas abertas e percebeu o aconchego do interior de uma touceira de bambu. Acusou a diferença de temperatura entre dois troncos de uma mesma espécie de eucalipto. Comparou a depressão no tronco ao "buraquinho do queixo do pai", que reconhecia quando pequena.

Mario, de 42 anos, por sua vez, no passeio pelo Parque Trianon, queria entender como era a base da árvore, e como ela saia da terra. Interessava-se pela maneira como tudo brotava do chão e na terra se sustentava. É a natureza se comunicando com as pessoas cegas, expressando-se, convidando ao entendimento.

Paramos para lanchar. O lanche é composto de frutas, barras de cereais, sucos e água de coco embalados. Cada item possui etiqueta em braille. Ouço depoimentos sobre o passeio:

Eu achei uma experiência muito bonita, muito saudável, a gente teve uma verdadeira aula de como sentir, de como tocar, comparar as diferenças, fazendo muito mais do que jus ao nome de Os sentidos da Paisagem. Eu adorei e fico feliz por fazer parte desse projeto. Um dos pontos enfocados e que podem ser curtidos pelo tato é a percepção da parte viva e morta de uma árvore. Achei isso super 10! (Mario)

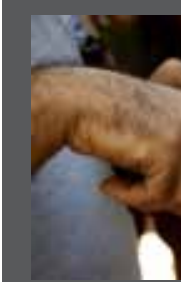
(
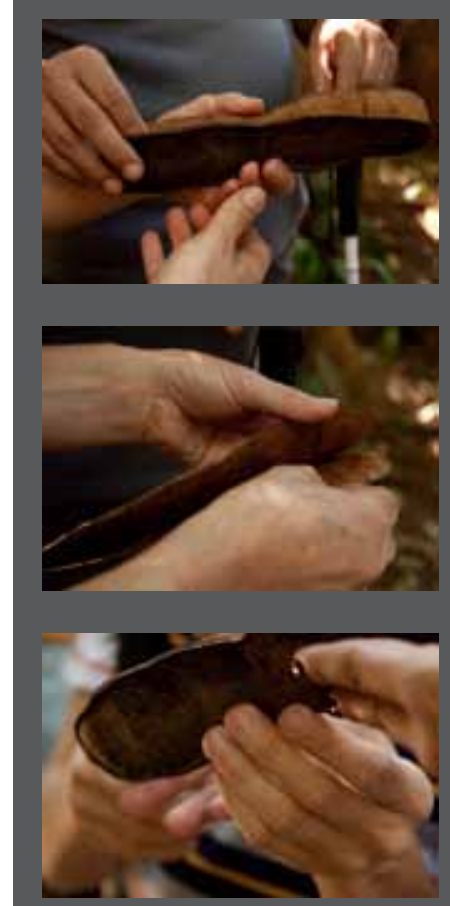

Todos se interessam pela vagem. Eu acho que esses projetos que você desenvolve são fundamentais. Você está incluindo o deficiente visual onde ele não tem oportunidade de ir. São poucas as oportunidades de ir a um parque, conhecer tudo, a vegetação, o que tem de acessibilidade, e de ter alguém com esse entendimento do professor Vitor. Gostei de tudo, de estar aqui, conhecer mais gente, conhecer seus filhos e estar ajudando pessoas que não têm muita oportunidade de ter contato com pessoas com deficiência visual. Estar convivendo com a deficiência. (Toninho) Eu achei muito interessante, sempre me interessei pelas árvores, pelas plantas, a gente não tinha parado para pensar como era preservar, estava fazendo coração na árvore achando que era coisa inofensiva. É romântico para a gente e está ferindo a planta. Conhecer, 
diferenciar uma árvore da outra, saber quantos anos leva para chegar ao ponto, achei muito interessante. Se o pessoal tivesse consciência disso pensaria duas, três vezes antes de cortar. O parque dentro da cidade é maravilhoso, a gente aqui dentro consegue esquecer que tem esse barulho em volta. Aproveitar o verde, a frescura da mata é muito bom. (Vicente)

Paulo dá o seu depoimento:

Achei o lanche uma delícia, foi legal ter água de coco, um dia de calor, a gente caminhando, achei muito bem pensado, a água de coco hidrata legal. O lanchinho tem uma sacolinha gostosa de tatear, tem o braille escrito em cada coisa, achei isso um cuidado que torna o passeio mais agradável, né? Muito bem planejado, diferenciado. Foi legal porque não tinha nada exótico, assim, picolé de jaca (risos). Barrinhas de chocolate com banana é difícil alguém não gostar. O Mario teve uma reação muito feliz quando ele leu lá "bom passeio", mexeu no saquinho, ele falou: - "nossa, braille em tudo, que chique", bem espontâneo, bem contente. Um extra, além dos beneficios do passeio, esses detalhezinhos assim são muito valiosos pra quem tá participando, né?

E sobre o conhecimento da regiáo:

Coisas que eu náo sabia e que foi muito bom aprender sobre a história do bairro, da arquitetura, da vegetaçâo. O porquê do nome da Rua Bela Cintra, e que a Avenida Paulista era cheia de árvores. Coisas que eu não sabia, que a cidade tinha muitas áreas alagadas, onde ficavam as áreas de vegetação alta e de vegetação arbustiva, isso vai formando um sentido de compreender a cidade, quais devem ser as soluçóes, o planejamento urbano para o futuro, uma maneira de pensar o planeta.

Sobre o parque:

Conhecia o parque da minha infância, da época que eu enxergava, lembrava pouco, tinha uma imagem mais ou menos vaga da vegetação, de árvores altas, então foi muito bom poder retornar a esse espaço que tinha sido tão valioso para mim na infância. E conhecer de outro jeito agora, descobrir que posso conhecer o parque de 


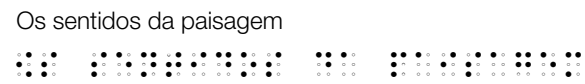

maneira mais rica também, sem enxergar com os olhos. Por exemplo, as texturas das árvores, tem um tronco frisado na vertical de uma maneira, com um paralelismo muito perfeito. E conhecer diferenças radicais, árvores que ao invés de ter frisadinhos muito pequenininhos, de um ou dois milimetros, tem grandes feixes de relevo, alguns mais paralelos, outros mais tortos. Muito prazeroso descobrir essas diferenças. Descobri formas de raizes mais verticais, outras mais horizontais, alguns troncos completamente enterrados sem aparecer as raizes, enfim, um grande aprendizado.

Pergunto se quando ele ainda enxergava, prestava atenção a isso.

Não via, não me interessava, na época o que me chamava atenção eram as copas, as flores, a visáo puxa o olhar para certos aspectos e o tato parece puxar para outros.

Questiono se a visão chamaria a atenção para o macro e o tato penderia para o micro.

Exatamente, mas ai, depois do passeio, eu fiquei com algumas curiosidades. Fiquei tão entretido com aqueles aspectos micros que não me ocorreu, por exemplo, perguntar como era a copa das árvores. É importante dar continuidade a essas atividades para acontecer esse conhecimento.

Reflito sobre a importância de se entender que tudo está interligado, a copa da árvore grande corresponde à projeção da raiz, nas árvores de grandes copas, as raizes crescem para longe dos troncos. Paulo comenta que esse é o tipo de conhecimento que precisa de suporte concreto como, por exemplo, miniaturas de árvores que sejam feitas da terra para cima, mas que também mostrem as raizes. E que acesso ao conhecimento é obrigaçáo do Estado oferecer nas escolas.

Lembro um texto de Aristóteles sobre plantas, onde ele diz que as plantas não crescem só para cima, crescem também para baixo, mostrando raízes. Imagino miniaturas com a divisão de espécies, palmáceas, leguminosas, crucíferas e suas características de nervuras verticais, anéis, excelente material para o ensino de ciências nas escolas.

Sobre umidade, temperatura, piso, Paulo comenta: 
Me chamou atenção o quanto é fresco. Eu não sabia que a vegetação assim mais "fechadona" é tão fresca. Porque costumo passear só no Parque Ibirapuera, não tinha tido aquele contraste de frescor em relação ao calor que está ao redor, foi impressionante passear pelas calçadinhas, aquelas cordinhas, alterna momentos de um caminhar mais solto, você pode ficar conversando com sua guia, não precisa ficar prestando atenção em buracos e pedras.

E sobre a interação de pessoas e natureza:

Uma grande interação de pessoas e natureza. Fiquei pensando na importância da companhia de um vidente para facilitar o contato do deficiente visual com o mundo. Várias vezes percebi isso, mas nesse passeio ficou muito claro pra mim o quanto é importante essa interação, promover o contato entre o cego e o vidente, estando esse vidente espontaneamente dedicado a essa companhia e interessado em mostrar o mundo e levando as mãos aos lugares aonde elas não chegariam sem ajuda. Então isso torna claro pra mim o quanto existe uma relativa dependência do deficiente visual em relação ao vidente em certos aspectos, e não estou falando em dependência no aspecto negativo. É preciso que alguém me leve até o lado de certa árvore, me mostre que ali tem uma determinada árvore, coisa que eu, sem enxergar, nâo teria condição de ficar explorando e andando pelo parque, dando cabeçada e tropeçando. É a apreensão do que está a distância e a indicação, esse gesto de mostrar $o$ que é fundamental para o cego, a criação de uma cultura onde se mostram as coisas.

O psicólogo reflete sobre a necessidade do contato com "as coisas do mundo", o acesso aos conceitos, ao que está distante e as interaçóes com outras pessoas. Há um empobrecimento em se trilhar o mesmo caminho de ir e vir de casa para o trabalho, de casa para a escola, sem conhecer os detalhes dos locais por onde se anda. Pessoas que enxergam podem levar a mão da pessoa cega a perceber e identificar o que está à sua frente. E, no momento em que isso é feito, a pessoa com deficiência visual passa a relatar tudo o que está identificando e que, muitas vezes, a pessoa vidente não percebera. Muitas vezes, há receio de se dirigir à pessoa cega, há falta de conhecimento e não necessariamente preconceito: como oferecer ajuda sem ofender, como guiá-la por um caminho, por uma escada?

A interação enriquece a todos nós e fica nítido que grande parte do estranhamento entre pessoas 
$\because \because \because \because \because \because \because \because \because \quad \because \because \quad \because \because \because \because: \because \because$

que enxergam e que não enxergam com os olhos acontece por falta de convivência, por falta de intimidade. Se a cidade estiver mais preparada para receber as pessoas com deficiência e os cidadáos passarem a usufruir dessa convivência, o estranhamento tende a diminuir.

Paulo completa:

Na hora que a gente chegou, o professor estava explicando uma série de coisas, tinha um parquinho ali perto e um barulho de balanço: inhec inhec. Eu achei tão bonito isso, para mim é uma visão, ouvir o barulho das crianças brincando no parquinho infantil é a minha forma de enxergar o parque, de saber que tem um balanço, uma criança ali rindo. 



\section{CONCLUSÕES INCONCLUSIVAS ${ }^{1}$}
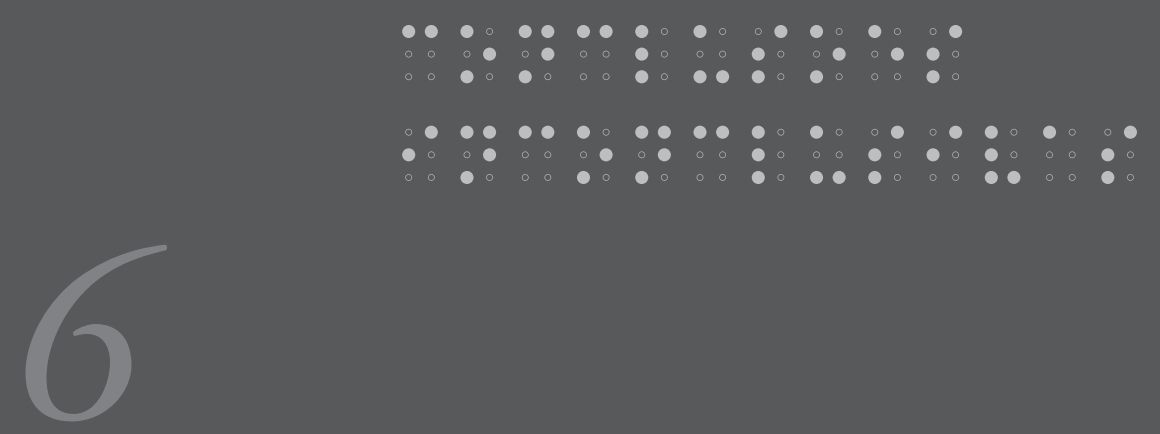

O exercício de percepção da paisagem urbana pede pausa e atenção. O ritmo de vida das grandes metrópoles, cada vez mais acelerado, antagoniza e muitas vezes impossibilita a apreensáo crítica das sensaçóes, ou seja, a percepção. Pessoas que enxergam e que não têm problemas de mobilidade se deslocam pela cidade com a atenção voltada para o seu destino, desenhando em traços rápidos os seus percursos. O ritmo apressado do cotidiano impóe rótulos que facilitem o entendimento automático, ignorando que rotular pode implicar em preconceber e desperdiçar.

Se, no entanto, pedimos a ajuda de uma pessoa cega, o ritmo da apreensão da paisagem tende a se alterar. Pessoas que não enxergam com os olhos conhecem melhor as texturas da cidade, seus ruídos, odores, obstáculos, barreiras. Colocam a sua atenção nos percursos, deslocando-se com cuidado, concentrados no momento vivenciado, orientando-se pela percepção e dialogando diretamente com a paisagem, por meio de suas texturas, saliências, topografia, imperfeiçóes.

Sons característicos do comércio, da construção civil ou de reparos realizados nas ruas; sons de máquinas, de animais, do ranger de um portáo que se abre ou mesmo do farfalhar das folhas são as vozes da cidade para as pessoas cegas. Odores de farmácias, bancas de jornais, lojas de tecidos, de couros;

1 Parafraseando Norberto Bobbio em Elogio da serenidade e outros escritos morais. p. 117, "Conclusão inconcludente" 
marcenarias, restaurantes, cafés, padarias compõem adições necessárias à orientação e ao deslocamento independente.

Texturas de muros e paredes, que absorvem ou refletem os sons, fachadas de vidro, longos caminhos de cerca viva, canteiros com plantas, amplos gramados ou grandes áreas abertas, podem servir como orientação ou perturbação para a pessoa cega que caminha sozinha. Pisos lisos ou com diferentes texturas, reentrâncias e saliências, os diversos acabamentos interferem e modificam a marcha. Até mesmo o vento, a chuva e as áreas sombreadas ou ensolaradas fornecem subsídios para o entendimento da paisagem, aquecendo, refrescando, desenhando os volumes das construçóes, das barreiras, do mobiliário, da arquitetura urbana.

Mas, a paisagem da cidade é constituída também pelas atitudes dos cidadãos. A receptividade, a aceitação e o acolhimento podem compor uma paisagem amigável, ao mesmo tempo que o estranhamento e as atitudes preconceituosas afastam, proíbem, impedem. A maneira como a paisagem é apresentada à pessoa com deficiência visual implica em como ela introjeta, interpreta e constrói os seus valores e a percepção das suas vivências. Embora não tenhamos uma constante consciência do fato, a maior parte de nossas experiências sensoriais nos vem pelo sentido da visão. É por meio dela que percebemos as cores, movimentos, escalas e o que ocorre em torno e distante de nós.

As pessoas que enxergam, ao descreverem para a pessoa cega as peculiaridades da paisagem, usam os conceitos das pessoas que enxergam, ou seja, os seus próprios conceitos, plenos de significados convencionais, comprometendo assim a apreciaçáo original e autêntica da pessoa que, sem enxergar, se apropria dos conceitos que lhe são passados. A própria paisagem urbana é construída nos moldes das pessoas que enxergam, de maneira que as pessoas que interagem no ambiente físico devem necessariamente poder contar com o sentido da visão para, em seus percursos, se capacitarem ao entendimento que ela exige.

Para que as soluçóes da arquitetura sejam acessíveis às pessoas com deficiência, é necessário ir além das normas técnicas de acessibilidade e do desenho universal; é imprescindível contemplar também o enriquecimento da paisagem, assim como já se faz com a funcionalidade e estética visual, de maneira que a pessoa cega possa percebê-la, sobre ela estabelecer valores e por ela despertar apreço.

A riqueza da paisagem está na diferença. A convivência com o diferente adiciona, engrandece, amplia, compreende, faz com que, pelas nossas açóes e reaçôes, conheçamos melhor a nós mesmos. Impóe a mudança de ritmo indispensável para a percepção enriquecida, propóe o aprimoramento da sensibilidade e o entendimento do corpo; estimula compaixão e reciprocidade, a compreensão do outro, 
o sair de si para ser solidário. Mais do que isso, a convivência com o diferente, que propicia a acurada percepção da paisagem, nos dá indicaçóes para a construção de uma cidade mais amigável e aponta para espaços onde o cotidiano se desvela em momentos de melhor qualidade de vida.

Não deve ser utopia buscar uma paisagem urbana que acolha indiscriminadamente todos os cidadãos e propicie a convivência harmoniosa, em espaços desenhados com as referências das medidas do corpo e que contemple o ser humano em primeiro lugar. A saúde da cidade e dos cidadãos está interligada. Depende da vontade e do conhecimento dos cidadãos e dos que desenham a cidade, multiplicar nas áreas externas os espaços de acolhimento e conforto que compomos dentro de nossas casas.

As ruas e as calçadas são áreas externas de residências, edifícios, de espaços públicos aos quais têm acesso todos os cidadãos. Cenários de vida devem receber cuidados, propiciar espaços de pausa e descanso, deslocamento seguro, acesso com independência e receptividade a todos os cidadãos, com ou sem deficiência aparente.

Durante o período de duração desta pesquisa, caminhei pela cidade com pessoas cegas que apontaram pontos positivos e negativos no tecido urbano. Com essas pessoas aprendi que muitas vezes as reaçóes de estranhamento dos cidadãos acontecem pela falta de convivência e intimidade com o diferente e não necessariamente por um comportamento preconceituoso. Uma cidade acolhedora propicia o convívio de todos, favorece as interaçóes, proporciona as condiçóes necessárias para a exposição, incitando pessoas com deficiência aparente a abandonar o seu resguardo para compartilhar a paisagem com pessoas sem deficiência visível.

Mas, o que torna uma cidade mais acolhedora?

Com contribuiçôes dos protagonistas da pesquisa iniciei uma relação de sugestôes para a construção de espaços públicos, no sentido de facilitar a caminhada e a convivência de pessoas nas cidades. As contribuições continuam chegando, portanto a relação, inconclusiva, encontra-se em aberto. As indicaçôes, de início, se assemelham muito às ações de acessibilidade. Isso mostra que pessoas com deficiência dependem da adequaçáo do espaço físico para a locomoção segura.

Encerro este trabalho com as contribuiçóes para uma cidade mais amigável, abordando tópicos que estão nas falas dos cidadãos: problemas nas calçadas, soluçóes inadequadas em espaços públicos, sistema de transporte público deficiente, problemas antigos e conhecidos. Proponho, no entanto, que se perceba tudo sob outro enfoque, libertando-se da prisão hegemônica da visão, fechando os olhos para que se possa vislumbrar a riqueza que está sendo desperdiçada. Quem sabe de olhos fechados tenhamos condiçóes de enriquecer o tecido urbano, o que não temos feito de olhos abertos. Com os olhos fechados, talvez consigamos colocar o foco mais no cidadão e menos nas características da estética visual do projeto. 


\section{CONTRIBUiÇÕES PARA UMA CIDADE MAIS AMIGÁVEL}

A pele da cidade - calçadas; identidade tátil..........................................................................249

Mobilidade - transporte público; bicicletas; o compasso da cidade ................................... 257

Pare, toque, escute - telefones; semáforos; banheiros; elevadores....................................... 261

Espaços para estar e conviver - cidade e campo; pontos de referência .................................. 266

Uma cidade ubíqua - U-city: a cidade interligada ........................................................... 270

Qualidade de vida - açóes ................................................................................................ 271

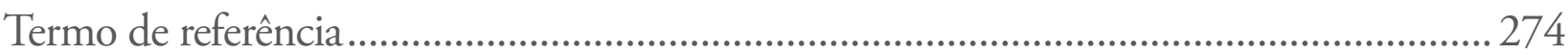

Em 2008 o arquiteto americano Chris Downey, de 45 anos, começou a atuar como diretor da construtora Michelle Kaufmann Designs de Sáo Francisco. Na empresa, especializada em projetos e construção de residências, o arquiteto fazia contatos com clientes, administrava e coordenava negócios e projetos. Com dois meses e meio de trabalho, Downey perdeu a visão em consequência de uma cirurgia para retirada de um tumor no cérebro, diagnosticado semanas antes.

De volta ao trabalho, apenas um mês depois de ter ficado cego, ele aponta o que mudou na sua percepçáo e atuaçáo como arquiteto, em entrevista publicada em setembro de 2010, na revista norte-americana The Architect's Newspaper². Downey discorda de que a profissão do arquiteto, por envolver desenho, seja meramente visual. Reflete que se trata de uma empreitada criativa, que envolve consideraçóes, pesquisa, estudo. E, sobre a acessibilidade, comenta que locais como aeroportos, museus, centros de trânsito, não podem ser considerados acessíveis apenas com uma adaptação improvisada, como se fosse uma aplicação de um simples band-aid.

2 Q\&A> ARCHITECT CHRIS DOWNEY FINDS SECOND SIGHT - After brain surgery left him blind at 45, a San Francisco architect rediscovered the full sensory world of design http://archpaper.com/news/articles.asp?id=4814 - visitado em 02/2012 (tradução minha). 
Depois que perdeu a visão passou a desenhar em uma prancheta que, com pressão, permite o recurso do relevo. Aprendeu também perceber o todo a partir dos detalhes, ao invés do que anteriormente lhe permitia a visão, enxergar primeiramente o todo para depois perceber os detalhes. Aponta que as pessoas que o guiam pelas ruas da cidade o fazem de maneira a evitar obstáculos, sem perceber que são exatamente os detalhes que lhe permitem identificar o local: uma simples batida em um ponto com a bengala, um som de uma parede ou muro, a maior reverberação dos ruídos nos espaços com tetos mais altos.

Os materiais também passaram a ter novos significados e as soluçóes, antes visuais, agora incluem texturas. $\mathrm{O}$ arquiteto constata que gosta de pensar as maçanetas das portas de entrada como "o apertar de mãos de um edifício"3 e que o agarrar comunica volume. O mesmo acontece com os corrimáos, mas os arquitetos estão tão ocupados com os projetos e a construção, constata ele, que se esquecem de como realmente é habitar o edifício. Mesmo com toda a tecnologia disponível, reflete, a arquitetura se mantém como uma experiência plenamente sensória. As mesmas indicaçóes do arquiteto Chris Downey estão presentes nas falas dos protagonistas desta pesquisa.

\section{A pele da cidade}

\section{Calçadas}

Pessoas videntes caminham pelas ruas das cidades muitas vezes com o pensamento voltado para o local de destino, mais do que para a própria caminhada. Pessoas cegas, no entanto, estão constantemente em contato com a pele da cidade, sentindo no corpo as diferentes superfícies, indicadores de orientação. Caminham atentas, colocando atenção em cada passo, no espaço, nas texturas e sons, no tempo da caminhada e em como esse conjunto de fatores pode contribuir para a sua segurança.

O péssimo estado das calçadas aparece em primeiro lugar, quando se fala em caminhar pela cidade. Buracos, remendos em desnível, degraus, bueiros abertos, sacos de entulho e de lixo, pedras soltas, cadeiras de bares, poças d'água, fezes de cães, vasos, jardineiras, árvores, raízes, postes, placas, entradas de garagem, lixeiras, orelhóes, portóes abertos e até automóveis estacionados sobre a calçada são alguns dos obstáculos que os pedestres têm que transpor.

Desníveis na calçada ou no encontro da camada de asfalto com o meio-fio podem ser evitados por videntes atentos e que não tenham problemas de locomoçáo. Entretanto, qualquer saliência ou fresta pode

3 Indicação de que conhece a obra do arquiteto finlandês Juhani Pallasmaa 

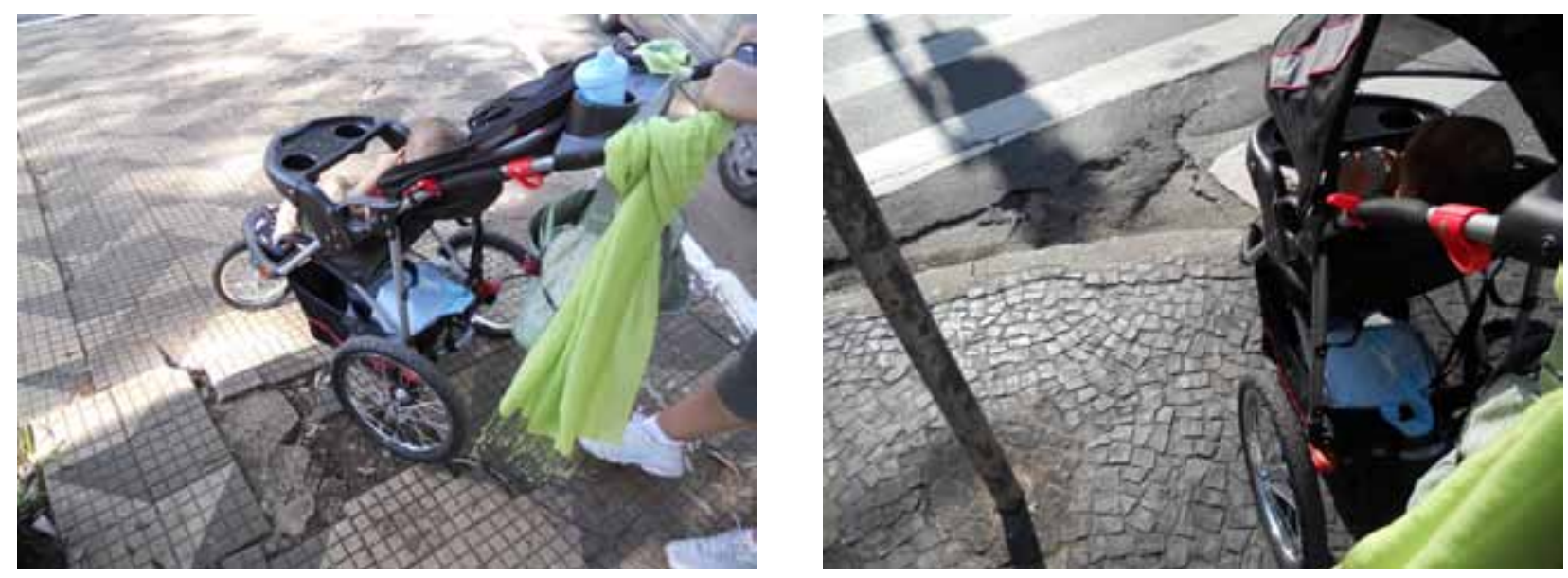

Calçadas dos bairros Itaim Bibi e Jardins

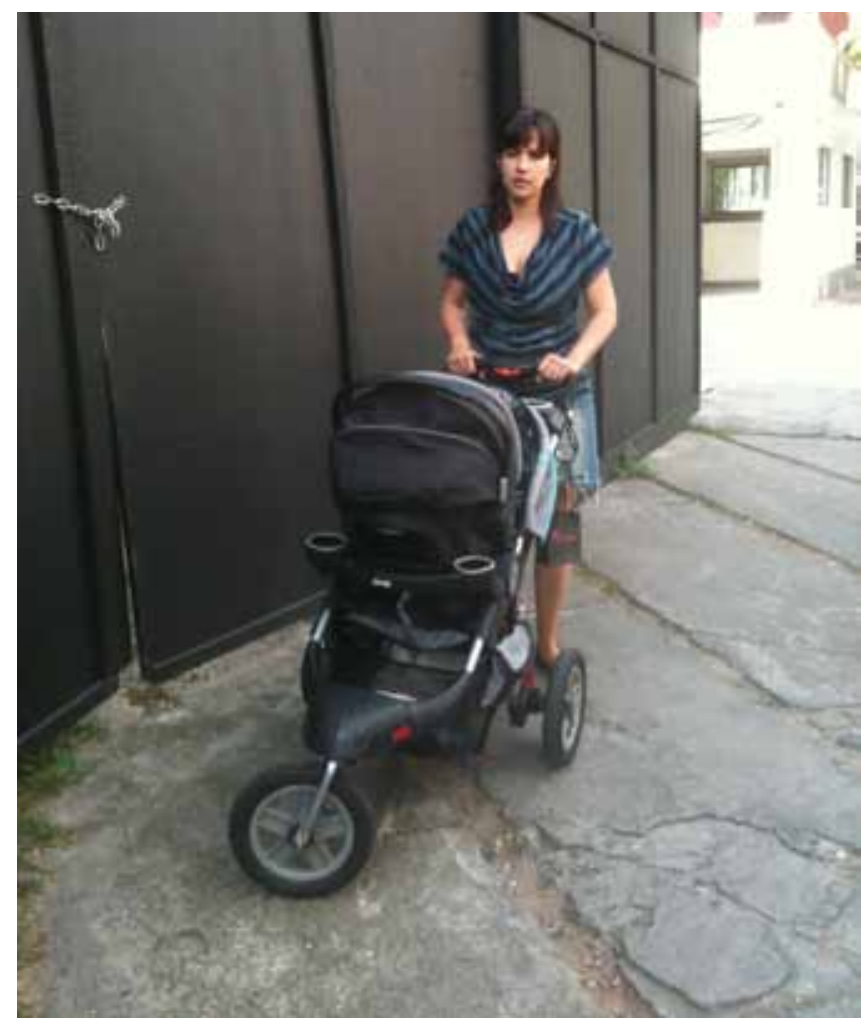


significar comprometimento e mesmo impedimento, quando analisamos o deslocamento de pessoas cegas, idosos com equilíbrio precário, crianças, pessoas com sequelas de AVC, pessoas em cadeiras de rodas.

A mídia tem noticiado com frequência o assunto das calçadas, as leis e a opiniáo dos cidadãos a respeito. A edição número 808 da Revista da Folha ${ }^{4}$ registra que "reformados ou não, os passeios são um teste para o paulistano que se aventura a pé pela cidade." A reportagem entrevistou cinco paulistanos, entre eles uma máe, uma pessoa com deficiência visual, mulheres usando salto alto e uma pessoa com cadeira de rodas. A mãe entrevistada, que tinha o hábito de caminhar pela cidade, depois do nascimento do filho perdeu o prazer de sair a pé. Segundo ela, empurrar o carrinho do bebê pelas calçadas é um pesadelo. Os trechos testados por ela estão em áreas nobres da cidade, como o do bairro Alto de Pinheiros ao Parque Villa Lobos. Outras tentativas foram feitas no bairro de Vila Madalena, nas ruas Harmonia e Purpurina, pontos críticos onde foram constatados muita trepidação, fendas, buracos, rachaduras.

Calçadas em más condiçóes foram encontradas também pelo atleta detentor do recorde parapanamericano de supino. Para o halterofilista Alexandre Whitacker, que se locomove em cadeiras de rodas, três quadras na Avenida Engenheiro Caetano Alves, na Zona Norte, são suficientes para cansar. Um vão entre o piso e a tampa do bueiro, um totem da CET no meio da calçada e falta de rampas para a cadeira de rodas foram alguns dos obstáculos encontrados pelo atleta.

A vereadora Mara Gabrilli, que também usa cadeira de rodas, questiona o piso intertravado da Rua Augusta. Assentado com areia, sem rejunte de argamassa, não sobreviveu às primeiras chuvas, devido ao declive da rua. Posteriormente, a calçada foi reformada com rejunte de cimento para não provocar acidentes, mas perdeu o seu apelo ecológico. Caminhando pela extensáo de duas quadras na Avenida Paulista, uma pessoa com deficiência visual definiu o passeio como um verdadeiro pesadelo. Encontrou barreiras como vasos, mesas de bar, orelhão, vendedores ambulantes, banca de jornal e uma enorme poça d'água.

Em agosto de 2010, matéria do jornal O Estado de Sáo Paulo ${ }^{5}$ constatou que depois de dois anos da criação do Plano Emergencial de Calçadas (PEC), apenas 63 das 315 vias escolhidas foram consertadas. O plano da prefeitura era reformar 1.575 quilômetros de calçadas em vias de maior movimento. O jornal percorreu 40 das principais vias selecionadas pela prefeitura e constatou que apenas três delas tinham mais de dois quilômetros de calçadas reformadas. O PEC planejava reformar as calçadas nos

4 Por onde andas? Revista da Folha. Jornal Folha de São Paulo, 16 de fevereiro de 2008, reportagem de capa.

5 Plano emergencial reformou apenas 20\% das calçadas. O Estado de São Paulo, Caderno Cidades. 10 de agosto de 2010 , p. 
moldes de acessibilidade da Avenida Paulista. Depois da reforma feita pela prefeitura, a responsabilidade pela manutenção seria dos proprietários dos imóveis. Segundo a autora da lei, vereadora Mara Gabrilli, "falta vontade política para cumprir a lei. A Prefeitura tem na mão um instrumento para fazer passeios de qualidade e não usa”.

Na mesma matéria do jornal, a médica Julia Greve, do Hospital das Clínicas, aponta que em 2003 mais da metade das quedas atendidas no Hospital foram causadas por tropeçóes em vias públicas, devido à má qualidade das calçadas. As mais afetadas foram pessoas idosas, com fraturas no quadril e ombro, além de hematomas faciais. Segundo a médica, no estudo feito em 2003 até óbito foi constatado. O estudo registrou um buraco a cada sete metros; o estado das calçadas continuou piorando.

Em janeiro de 2012, reportagem do jornal O Estado de Sáo Paulo ${ }^{6}$ cita a Lei 15.442 que estipula aumento da multa por metro linear da calçada. A responsabilidade das condiçóes da calçada passa também a ser de quem ocupa o imóvel, e não mais do proprietário. Cidadãos entrevistados pelo jornal, no entanto, discordam e imputam a responsabilidade à Prefeitura, pois as calçadas seriam assunto público, e não particular.

Nova reportagem, em março ${ }^{7}$, noticia pesquisa realizada pelo Instituto Informa, que a pedido do jornal entrevistou 1.000 cidadáos. O resultado da pesquisa mostra que mais da metade dos entrevistados não está preocupada com o assunto. Amauri Pastorello, gerente de calçadas da Prefeitura de São Paulo, acredita que vai demorar para os cidadáos de conscientizarem da necessidade de reformar as calçadas, pois falta cidadania e responsabilidade social. A reportagem aponta ainda que apenas 45,6\% dos cidadãos se preocupam, enquanto 53,6\% não estão sequer preocupados com o assunto.

Além das discussões sobre imperfeiçôes e obstáculos, há a questão da escolha do pavimento. Nas calçadas encontramos grande variedade de revestimento: simples feito com cimento, pavimento intertravado, pedra, cacos de diversos materiais, concreto pré-moldado, ladrilho hidráulico liso e com sulcos profundos, entre outros. São as reentrâncias dos ladrilhos hidráulicos e as imperfeiçóes do piso que prendem a ponta da bengala da pessoa cega, causando contusão dolorida quando o cabo da bengala atinge de volta sua perna ou seu abdômen.

Um dos acabamentos de calçadas que recebem bem a bengala das pessoas cegas é o de cimento pré-moldado ou cimento liso, como mostra a foto. No entanto, é desejado que o calçamento contribua também para que pessoas cegas andem em linha reta. Considerando-se que a hapticidade responde mui-

6 Entra em vigor lei das calçadas que triplica multa. O Estado de São Paulo, Caderno Cidades, 9 de janeiro de 2012.

7 Buraco na calçada rende 13 multas/dia. O Estado de Sáo Paulo. Caderno Cidades, 18 de março de 2012, p. C4. 
to bem aos contrastes, se as calçadas combinarem faixas de materiais de texturas diferentes, a caminhada em linha reta pode se tornar mais fácil para essas pessoas. A superfície lisa, combinada à textura, auxilia sobremaneira a orientação e o direcionamento da caminhada.

O mesmo acontece em grandes áreas. Em praças, como a atual Praça da Sé, ou no Memorial da América Latina, não há referência de orientação para pessoas cegas. Um grande espaço vazio, com piso de textura única e uniforme, sem fonte com ruído de água, distante da rua e do ruído dos carros, configura impedimento para o deslocamento independente da pessoa cega. Na Praça da Sé, por exemplo, desenhos no piso, faixas com material de textura diferente, em um jogo de liso/áspero, poderiam conduzir a pessoa que não enxerga para a escadaria do Metrô ou às ruas do entorno da praça.

Na grande área externa à entrada principal do Pátio do Colégio, região do Centro Histórico de São Paulo, há um bom exemplo de contraste de texturas, criado talvez como recurso estético visual, mas que, uma vez apresentado à pessoa cega, facilita o acesso à entrada principal do prédio. Em Buenos Aires, várias calçadas apresentam diferença de textura no piso, o que facilita a marcha das pessoas cegas e com baixa-visão.

Em São Paulo, ao contrário, não se dá atenção às texturas e muitas das calçadas reformadas com piso intertravado usam três cores do mesmo piso para diferenciar as faixas. Embora a reforma possa estar bem feita, faixas com textura uniforme em nada contribuem com a caminhada das pessoas que não enxergam.

A prefeitura de São Paulo disponibiliza na Internet uma cartilha com indicaçóes para a construção de calçadas ${ }^{8}$. Na página seis há orientação para a divisão da calçada em três faixas: 1 - faixa de serviço; 2 - faixa livre; 3 - faixa de acesso. A faixa de serviço fica próximo à rua e é destinada aos postes, rampas, árvores, acesso de veículos. A faixa livre fica reservada aos pedestres e deve ser livre de obstáculos. A faixa de acesso aos imóveis permite o acesso de veículos e pode receber vasos, mesas, cadeiras, toldos. As faixas são claramente visíveis, pois têm cores diferentes, mas não há menção à diferença de textura. Ou seja, a comunicação feita pelas faixas é apenas visual, destinada às pessoas videntes.

Para a área ser considerada acessível, instalar uma pequena faixa de piso tátil (piso podotátil) de alerta não é suficiente. Muitas vezes, essas faixas táteis que precedem as rampas são de $0,25 \mathrm{~m}$ de largura, insuficientes para a percepção. Pessoas cegas que usam sapatos especiais com solas grossas ou emborrachadas, como as que têm diabetes, queixam-se de que a indicação é imperceptível. Outras vezes o piso tátil é fixado sobre outro piso e com uso começa a se soltar, o que pode provocar quedas. Algumas pessoas 
cegas consideram com reservas o piso tátil, comentando que ele faz com que as pessoas andem em fila. Outras pessoas, como o protagonista Mario, se ressentem por pessoas videntes não respeitarem o uso exclusivo do piso, o que atrapalha a marcha da pessoa cega.

Completando a dificuldade das caminhadas pelas calçadas, há os obstáculos altos como toldos, galhos de árvores na altura do rosto, janelas das casas antigas que abrem para a rua, placas de sinalização e publicidade, entre outros. Nestes casos, há depoimentos de protagonistas que, mesmo sendo cegos, usam óculos de lentes comuns apenas para proteção dos olhos. Há também o depoimento do antropólogo norte-americano Ed Eames, já falecido, que saia às ruas de Fresno, na California, com uma tesoura de poda, para aparar os galhos baixos que encontrava, durante caminhada em companhia da sua mulher Toni.

JACOBS9 aponta que as calçadas das cidades servem para abrigar pedestres e que "as ruas constituem a principal paisagem das cidades" (2000, p. 421). Sem dúvida, temos ainda um longo caminho a percorrer para a melhoria das calçadas das nossas cidades.

\section{Identidade tátil}

\section{Metrô}

Os paineis que revestem as paredes das plataformas do Metrô e que têm cores diferentes em cada estação, poderiam também ter identidade tátil nas diferentes plataformas. Desta maneira, a pessoa cega saberia reconhecer a área e o ponto exato da sua localização. O primeiro vagão é reservado ao embarque preferencial das pessoas com deficiência. Uma marcação, ou uma textura diferente em um determinado painel da plataforma seria conveniente para pessoas cegas aguardarem na posiçáo certa do embarque. $\mathrm{O}$ protagonista Ricardo, usuário de muitos anos da estação Vergueiro do Metrô, desenvolveu esse recurso por conta própria, de maneira a não depender dos funcionários daquela estação para se dirigir ao embarque.

A marcação em painéis pode auxiliar e conferir identidade ao local. As texturas devem ser variadas, diferentes umas das outras, e estar em locais próprios de percursos de pessoas cegas. $\mathrm{O}$ recurso não exclui a necessidade de funcionários capacitados para acompanhar os usuários com deficiência, mas favorece àqueles que se locomovem com mais independência. Sobre o piso tátil, pessoas cegas reclamam que muitas vezes ele não é percebido pelos pés. Apontam também que em várias estações o piso tátil conduz e direciona a pessoa durante parte de um caminho e subitamente termina, em local não identificado e até mesmo em uma coluna, guarda-corpo ou parede. 


\section{Prédios públicos}

Prédios públicos também podem ter identidade tátil e assim facilitar o seu reconhecimento pelas pessoas cegas. Muitos desses prédios possuem mais de uma entrada, o que constitui uma dificuldade a mais para aqueles que não enxergam com os olhos. Uma grande fachada de vidro pode ter entradas laterais, alternativas, e uma central, principal, que conduz diretamente ao balcão de informaçóes. Como fazer esse discernimento sem enxergar?

Esses locais receberiam melhor as pessoas cegas identificando a entrada principal. Para pessoas que usam bengalas, pode ser apenas uma saliência em um canto reservado, ou um material que produza sonoridade com a batida da bengala. Conhecendo o recurso, a pessoa cega poderia facilmente identificar a entrada principal. A marca pode ficar em local discreto, na quina do canteiro, na lateral da rampa, no início da escada.

O mesmo recurso pode ser adaptado para outras situaçóes. Sandra e Ronaldo, casados, protagonistas da pesquisa, relatam as dificuldades para encontrar a porta do chalé do hotel-fazenda onde se hospedam nas férias. Como todos os acessos são idênticos, caracterizados por rampas de garagem, desde o momento em que saem do edifício-sede, onde fica o restaurante, o casal tem que se manter concentrado na contagem para não confundir as entradas de garagem, até que chegue a sua própria entrada. A simples colocação de um cesto diferente para coleta de lixo, ou uma saliência no ângulo do jardim, ou um guizo que balançasse e tocasse com o vento, ou ainda um objeto decorativo, mesmo que provisoriamente instalado, facilitaria a identificação do local ao toque da bengala.

No Centro Cultural São Paulo, no trajeto entre o acesso à estaçáo do Metrô e a porta principal de entrada do prédio, uma discreta mureta de contenção do jardim se presta a esse fim. As pessoas cegas acompanham a mureta com a bengala e sabem que, no ponto em que ela termina, encontra-se a porta principal de entrada.

Outra opçáo seria usar, na área externa, perpendicular à entrada principal, um piso com textura, simulando uma passarela. O piso pode ser de cor diferente, para pessoas com baixa visão, mas é necessário que tenha também uma textura diferente, para ser identificado por pessoas cegas.

Nas áreas internas, o piso antiderrapante é de vital importância. O relato do protagonista Ronaldo, ao caminhar pelo piso molhado do saguão de entrada da Secretaria da Fazenda, e a reação das faxineiras do prédio que se assustam, mas não sabem como ajudar, indicam uma clara necessidade de pisos antiderrapantes para áreas públicas. $\mathrm{O}$ cuidado com a escolha do piso favorece idosos, amputados, pessoas com dificuldades motoras, mulheres grávidas, obesos e também pessoas cegas. $\mathrm{O}$ uso de pisos de diferentes texturas em um mesmo edifício, a variação de materiais em paredes, colunas, estimulam a percepção e desafiam o entendimento dos frequentadores do local. A pobreza sensória de muitos prédios torna o espaço menos interessante, menos atraente. 
Os prédios da prefeitura de Säynatsalo ${ }^{10}$, Finlândia, projetados por Aalto e inaugurados em 1952, combinam tijolos vermelho escuro, outros tijolos de diversos tipos, madeira, cobre, vidro, argila, água, reboco, grama, granito, aço galvanizado, ladrilho. Um trançado de couro dá acabamento confortável à maçaneta de metal da porta de entrada. $\mathrm{O}$ piso alterna tijolo, madeira e granito, facilmente identificáveis pelos passos dos visitantes. Há detalhes como bancos fixos de tijolos, construídos em um corredor, para espera. Por uma fenda entre o banco e a parede passa o calor de um aquecedor instalado sob o banco. Esse recurso mantém o local sempre quente e agradável no inverno, além de garantir janelas secas.

O tratamento acústico também torna o ambiente mais confortável para todos e facilita a orientação de pessoas cegas. A diminuição de ruído na cidade é de vital importância, tanto em áreas externas quanto na parte interna de edifícios públicos. Há materiais alternativos para uso interno e externo e até mesmo asfalto que absorve melhor o som, feito com pneus reciclados. Este já começa a ser usado em rodovias e avenidas de movimento intenso, apesar do seu custo mais elevado. $\mathrm{O}$ argumento favorável, além da melhor absorção de ruído, é a maior durabilidade do material e o seu apelo ecológico.

\section{Mobilidade - transporte público, bicicletas, o compasso da cidade.}

\section{Transporte público - capacitação de funcionários}

O Metrô de São Paulo conta com funcionários capacitados para atender às necessidades dos usuários com deficiências, embora pessoas cegas reclamem que o número de funcionários não é suficiente para atender à demanda. As linhas de ônibus, no entanto, não capacitam cobradores e motoristas. $\mathrm{O}$ fato gera inúmeras situaçóes inadequadas, constrangedoras, equivocadas, onde o preconceito e a ignorância sobre a deficiência aparecem explícitos ${ }^{11}$.

Pessoas cegas precisam ser avisadas da aproximação e chegada ao seu destino. O cobrador deve ficar encarregado desse aviso, e deverá fazê-lo de maneira adequada, com tratamento respeitoso e educado. Os motoristas também devem ter o cuidado de parar próximo à calçada, para facilitar embarque e desembarque de todas as pessoas. Os funcionários devem estar preparados para um embarque e desembarque mais pausado, quando se tratar de um usuário idoso ou com deficiência.

O que encontramos atualmente, na maioria dos funcionários de ônibus da cidade, é um total despreparo e desconhecimento das necessidades das pessoas com deficiência. Entendemos que esses próprios

10 http://www3.jkl.fi/saynatsalo/townhall/en-350.htm

http://www.galinsky.com/buildings/saynatsalo/index.html - visitados em 03/2012

11 Leia mais sobre preconceito no Capítulo 3. 
funcionários sofrem pressóes da empresa para agir com rapidez, sentem-se mal remunerados, estressados pela exposição ao trânsito, mas nada justifica o tratamento que tem sido dedicado às pessoas com deficiência.

Não só o transporte urbano apresenta falhas e falta de adequação às necessidades de pessoas com deficiências. As companhias aéreas também não capacitam sua tripulação de terra e de voo para o atendimento adequado. Em entrevista ao jornal O Estado de São Paulo ${ }^{12}$, o escritor Marcelo Rubens Paiva, tetraplégico desde 1979, relata que no dia 22/07/2012, ao chegar a São Paulo, foi esquecido dentro do voo 3971, da empresa aérea TAM. Lembra que no período de 30 anos em que viaja de avião já aconteceu de tudo, inclusive a perda da sua cadeira de rodas motorizada. Conta que já ficou esquecido dentro de um veículo de transporte na pista do aeroporto, vendo o aviáo decolar sem ele. No Recife, foi derrubado no chão por um funcionário.

$\mathrm{O}$ arquiteto Fernando Porto de Vasconcelos, de 73 anos, está internado desde 2010, quando foi derrubado no elevador para cadeira de rodas, no Aeroporto de Congonhas. Segundo depoimento dado por sua filha, a arquiteta Moira Vasconcelos, ao jornal O Estado de São Paulo ${ }^{13}$, o motorista do "ambulift" freou bruscamente e a cadeira de rodas tombou. Como a funcionária da empresa Gol não havia afivelado o cinto de segurança, o idoso caiu e bateu a cabeça, sofrendo lesão no cérebro. A família abriu processo contra a empresa Gol e contra a Infraero.

Segundo o escritor e colunista do jornal O Estado de Sáo Paulo, Marcelo Rubens Paiva, o atendimento às pessoas com deficiência é feito por quem estiver à disposição, e não por funcionários capacitados, com procedimentos corretos como segurar a pessoa de forma adequada e usar luvas. Nesse sentido, prevê "um caos" para as paraolimpíadas do Rio, pois no aeroporto daquela cidade os táxis adaptados para pessoas com deficiência sequer têm local demarcado para estacionar.

\section{Bicicletas}

Em São Paulo a bicicleta é pouco usada como meio de transporte pela falta de facilidade e infraestrutura que a cidade oferece. As poucas ciclofaixas, distribuídas em curtos segmentos, funcionam com exclusividade apenas aos domingos, deixando o ciclista sem opção de uso durante a semana. Sáo Paulo tem 17 mil quilômetros de vias públicas, mas apenas 54 quilômetros de ciclovias, 48 de rotas com passagem preferencial e 3 quilômetros de ciclofaixa definitiva ${ }^{14}$. No ano passado, segundo a Companhia de

12 'Me devem desculpa", diz escritor que foi esquecido em avião. Jornal O Estado de São Paulo, Caderno Cidades, 24/07/2012, p. C8

13 Idoso derrubado em aeroporto está há 18 meses no hospital. Jornal O Estado de São Paulo, Caderno Metrópole, 26/07/2012, p. C6

14 De bicicleta, uma outra Sáo Paulo. O Estado de São Paulo, Caderno Cidades, 30/06/2012 
ampliar o projeto Bike Sampa nos próximos anos.

A Associação dos Ciclistas Urbanos de São Paulo ${ }^{17}$ promove encontros para discutir a relação entre planos diretores e planejamento cicloviário. Disponibiliza também em seu site um conjunto de propostas "que deverão nortear o trabalho de gestores(as) comprometidos(as) com a melhoria da qualidade de vida desta cidade e com a necessidade de transformar o modelo de mobilidade urbana em São Paulo”.

O oceanógrafo Helvio Gregório, de 29 anos, cansado do trânsito da capital, pedala 12 quilômetros todos os dias, de casa até o trabalho. No percurso, dá preferência às ruas arborizadas e com menos trânsito e comenta que assim descobre caminhos alternativos, ruas e bairros que náo conhecia. Em entrevista ao jornal O Estado de São Paulo (30/06/2012), comenta: "São Paulo é toda construída para carros. Se tivesse uma estrutura cicloviária que possibilitasse tanto sua irmã de 9 anos quanto sua mãe de 60 irem de um lugar a outro sem perigo, seria o ideal de sustentabilidade e qualidade de vida".

\section{compasso da cidade}

Caminhar tem sido uma das atividades mais indicadas para cidadãos de todas as idades. As relaçóes humanas se dão no contato com as pessoas, no contato com a alma e essa é uma parte fundamental da vida das cidades. Pessoas precisam estar em "con-tato", a cidade originalmente imaginada não é a cidade do automóvel. Ao caminharmos, interagimos com outros cidadãos, paramos para conversar, podemos nos tocar e nos perceber, entender a cidade e suas peculiaridades.

Caminhar pode ser, sim, determinante para se conhecer a cidade e os seus cidadãos, mas onde estão os pontos para pausa e descanso? Cidades como Tel-Aviv, em Israel, têm cadeiras nas ruas à disposição da população. Nesses locais é possível marcar encontros, sentar para esperar, apreciar o movimento, conversar, fazer novas amizades. Segundo Hillman, se a cidade não tem lugares para pausas, como é possível o encontro? (1993, p. 52)

Em Sáo Paulo, caminha-se por toda a Avenida Paulista sem que haja um único banco para se sentar. Protagonistas da pesquisa se ressentem do fato e apontam padarias, lanchonetes e bares com mesas nas calçadas como parada para descanso. Mas, a parada em

17 http://www.ciclocidade.org.br/

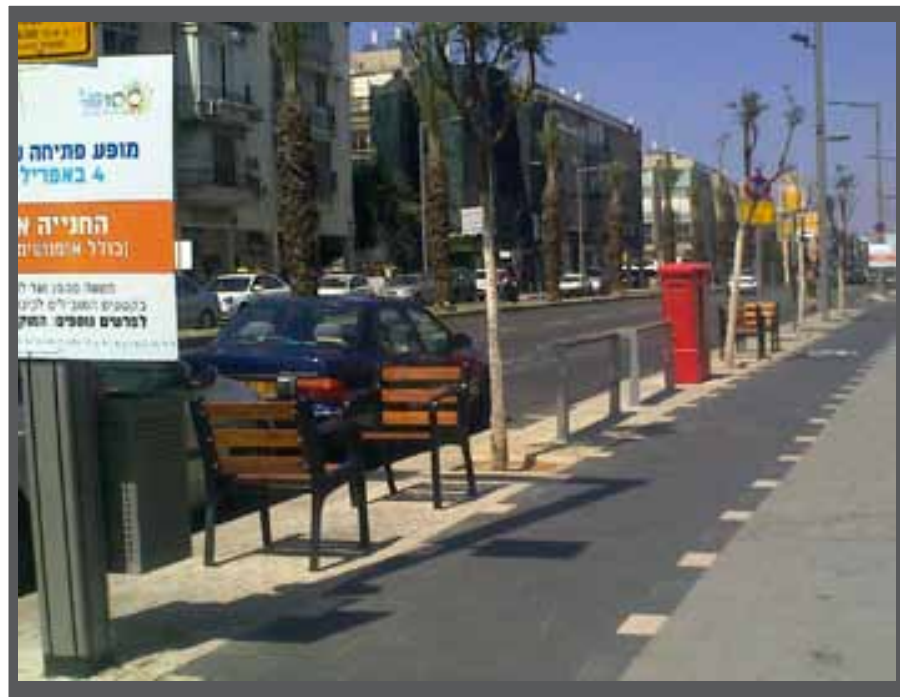


estabelecimento comercial envolve consumo. Sentar em bares, restaurantes, padarias, pode envolver dispêndio e este se encarrega de categorizar e, muitas vezes, excluir. $\mathrm{O}$ descanso, a convivência e interação dos cidadãos não podem depender apenas de espaços comerciais.

Calçadas mais largas, esquinas com recuos, pequenos becos, são espaços propícios a receber cadeiras, um ou dois bancos, uma jardineira com plantas, transformando o ambiente em um pequeno local de estar. São açóes de baixo custo, mas que humanizam a cidade, criam pequenas ilhas de convivência, estimulam o cuidado com o local, tanto da parte dos moradores, quanto das empresas e do comércio, que tem a opção de adotar a área, cuidando de sua manutenção.

\section{Pare, toque, escute - telefones, semáforos, banheiros, elevadores}

O homem é a medida de todas as coisas (Protágoras). Puxar, empurrar, agarrar, apoiar, segurar, tocar, encostar, apertar, as formas convidam ao toque: a alça é feita para ser puxada, o botão para ser apertado, a maçaneta girada, o corrimão segurado, a barra para favorecer o apoio. As formas devem dialogar com as máos que as tocam, capazes de identificar a frieza do metal, a neutralidade do plástico, o aconchego da madeira, o acabamento liso do vidro.

Mas nem sempre é o que acontece. A maçaneta não preenche a nossa mão e, muitas vezes, ao empurrarmos uma porta para entrar, tocamos uma alça que foi desenhada para ser puxada - a porta para ser empurrada deveria receber a mão espalmada. Segundo Merleau-Ponty, se a nossa atenção estivesse voltada para os objetos à nossa volta, se colocássemos a atençáo no ato de abrir portas, as maçanetas seriam desenhadas para acolher melhor as nossas máos.

Muitas das escadas de edifícios públicos não têm corrimãos, o que dificulta o trânsito de pessoas com ou sem deficiência. Além do corrimão para apoio, interessante seria explorá-lo como um meio de comunicação para pessoas cegas, com marcação em braille na parte inferior, registrando informaçóes como localização do andar e aviso de portas de emergência. É importante lembrar que idosos frequentemente têm problemas com equilíbrio e alças de apoio e corrimãos são peças importantes e necessárias. Edifícios com grandes áreas abertas, sem proteção de guarda-corpo, como o próprio prédio da FAU/ USP, propóem uma estética visual, mas também oferecem risco de queda para crianças, idosos, pessoas com deficiência visual.

Sentimos prazer em pisar descalço em um tapete macio e tocar com as mãos um material suave. A escada tem a medida do passo e respeita a dimensão do nosso cansaço. O tijolo absorve o som, enquanto o azulejo o potencializa. Embora atualmente haja uma infinidade de materiais disponíveis, muitas vezes 
os produtos usados na arquitetura e decoração, como por exemplo as maçanetas de portas, não oferecem grande variedade de formas.

O intrigante Centro Cultural construído em Järna, Suécia, um dos projetos mais importantes do arquiteto Eric Asmussen ${ }^{18}$, apresenta diversas soluçóes criativas. Há vários anos, os arquitetos Gary J. Coates e Susanne Siepl-Coates do College of Architectute, Planning and Design, da Universidade de Kansas, pesquisam a arquitetura de Asmussen. Em artigo publicado no Journal of Healthcare Design (vol. 8, 1998), apontam características do projeto de um centro de saúde que funciona desde $1985^{19}$.

$\mathrm{O}$ artigo chama a atenção para os princípios encontrados na arquitetura de Asmussen, a ciência fenomenológica da natureza, e cita os seven principles of healing architecture: unidade de forma e função; polaridade; metamorfose; harmonia com a natureza e o lugar; paredes (divisórias) vivas; luminosidade e perspectiva da cor; o equilíbrio dinâmico da experiência espacial (tradução minha).

\section{Telefones públicos}

Um dos projetos que pedem urgente revisão é o do chamado "orelhão". Pessoas cegas apontam os orelhóes como um dos obstáculos mais frequentes na cidade. Os aparelhos, quando possuem marcação, têm apenas um contorno de piso tátil com 0,25m de largura. No entanto, é impossível detectar o orelhão apenas com uma linha de contorno ao seu redor. Pessoas com baixa visão, ou pessoas cegas, acabam batendo a cabeça e se machucando, pois a bengala não acusa a diferença de piso e muito menos o poste de sustentação do orelháo, que é fino e fica recuado em relação à forma oval que atinge a testa das pessoas cegas.

Há diversas outras opçóes para a situação:

- instalar o orelhão sobre uma sapata, um piso saliente elevado do chão, com medidas pouco maiores do que a projeção da forma oval.

- instalar o telefone público dentro de cabines, como acontece na Inglaterra.

- desenvolver outro tipo de textura mais saliente que fosse colocada excedendo a área do orelhão, e não apenas uma linha no contorno da projeção do aparelho.

18 http://wn.com/Erik_Asmussen visitado em 03/2012

19 http://antroposofi.org/vidar/healthcare.htm. Acesso em 03/2012

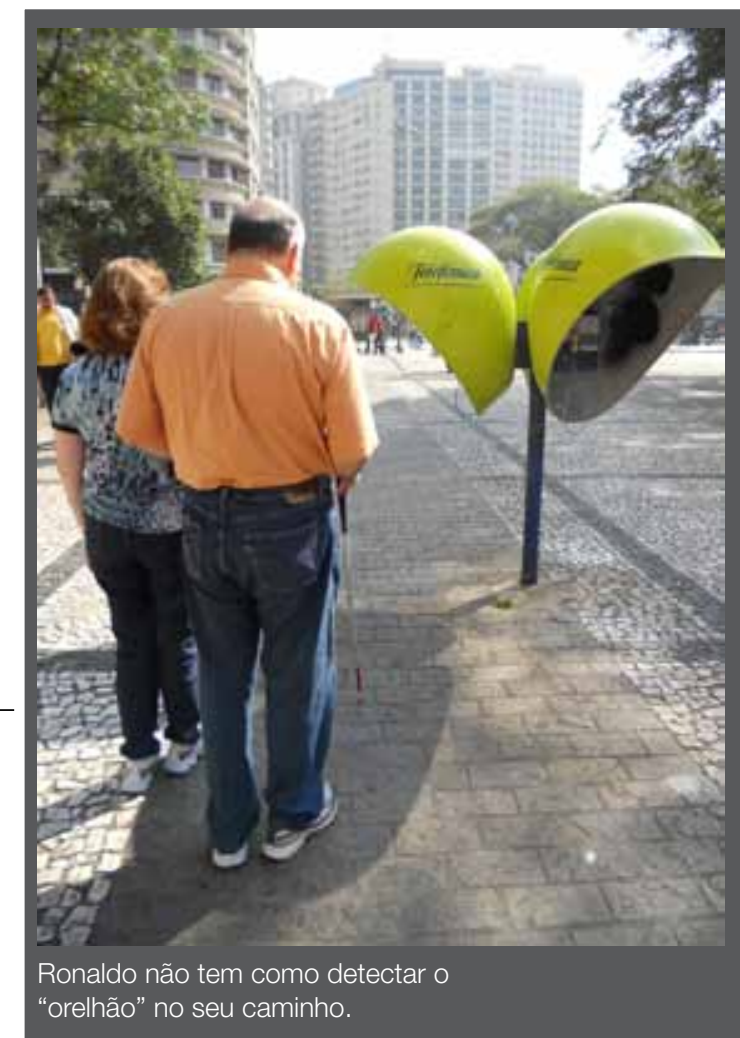


No entanto, quando se pensa em alteraçóes para esses aparelhos, elas surgem apenas como uma abordagem visual. Matéria do jornal O Estado de São Paulo ${ }^{20}$ informa que os orelhóes estão ganhando nova roupagem, perdendo a cor verde-limão e sendo repintados de roxo, azul, laranja e verde. Nos próximos meses, diz o texto, os 198 mil orelhôes do Estado de São Paulo já terão cores novas. A matéria traz um pouco da história do projeto do mobiliário urbano, das novas pinturas personalizadas, do trabalho de manutenção que repara atos de vandalismo, mas ignora o fato de ser uma ameaça severa para pessoas com deficiência visual.

\section{Semáforos sonoros}

Cada vez mais comuns em cidades norte-americanas e canadenses, os sinais sonoros são confiáveis e funcionam bem, apenas em países onde os motoristas respeitam os pedestres. Norte-americanos idosos e com deficiência visual já contam com sinal sonoro em uma das esquinas mais perigosas de New York, a West 23 com a 7a Avenida. O sistema combina som, voz e sensaçáo tátil. O aparato preso a um poste emite um sinal de bip para indicar onde está o botão de comando. Quando pressionado, uma voz indica se o pedestre deve aguardar ou atravessar. Quando a travessia pode ser feita com segurança, a voz vem acompanhada de uma vibração tátil.

Durante seis anos, o professor de Ciência da Computação e Engenharia Elétrica Richard Wall, da Universidade de Idaho, coordenou uma pesquisa para desenvolver um sistema denominado Advanced Accessible Pedestrian System - AAPS ${ }^{21}$. O aparato já está sendo produzido comercialmente por uma empresa americana. $\mathrm{O}$ sinal para pedestres funciona visualmente, como um semáforo tradicional, mas tem também aviso sonoro e de toque, formando um conjunto de informaçóes para possibilitar que se atravesse com segurança. O AAPS já está sendo instalado em várias cidades norte-americanas e é um exemplo de como as pesquisas universitárias podem ser desenvolvidas para solucionar problemas da comunidade ${ }^{22}$.

20 Orelhóes terão novas cores: verde, roxo, azul e laranja. Fabiano Nunes, Jornal da Tarde - O Estado de São Paulo, 19 de maio de 2012, Caderno Cidades, p. C8

21 http://www.uidaho.edu/newsevents/item?name=crosswalk-insights-for-the-vision-impaired - visitado em $03 / 2012$

22 As escolas devem ser estimuladas a incluir nas suas pesquisas os problemas das comunidades. Estudantes do $9^{\circ}$ ano da escola Stance Dual, de São Paulo, passaram um semestre pesquisando as dificuldades encontradas pelas pessoas com deficiência. A partir dessa experiência, criaram um guia turístico bilíngue - inglês e português. $\mathrm{O}$ site tem recurso de áudio e indicaçóes de museus, teatros, cinemas, restaurantes e parques acessíveis. Disponível em: http://stanceblog.com.br/whatson/ - visitado em 25/06/2012 - Noticiado pelo jornal O Estado de Sáo Paulo em 19/06/2012 - Caderno Viagem, p. V5.

Outro bom exemplo está sendo desenvolvido em Santa Rita do Sapucaí, por três jovens alunos da Escola Técnica de Eletrônica daquela cidade. Joaquim Eduardo de Oliveira, Luana Pereira Vaz de Lima e Wellington Borsato Rodrigues criaram um colete chamado Visão Interativa para Deficientes - VID. O colete funciona como um sensor, que vibra quando a pessoa cega se aproxima de um obstáculo. 
No Canadá, experiências com sinais sonoros testam melodias e cantos de pássaros para sinalizar uma travessia segura. $\mathrm{O}$ aparelho fixado ao poste inclui uma seta que indica a direção da travessia, uma vez que em esquinas o sinal pode confundir a direção da travessia segura. No Brasil, pessoas com deficiência visual preferem contar com a ajuda de videntes para atravessar as ruas, mesmo que essas pessoas não tenham o conhecimento de como conduzir uma pessoa cega. A segurança, nas grandes cidades brasileiras, parece estar atrelada à capacidade de enxergar. No entanto, os sinais sonoros podem indicar a duração da travessia e estabelecer o ritmo da caminhada: quando o trecho da melodia conhecida for acabando, a pessoa deverá estar próxima ao outro lado. Isso poderia ser conseguido com melodias clássicas do repertório popular brasileiro, de conhecimento de todos, como Tico-Tico no Fubá ou Brasileirinho.

Embora os motoristas não estejam habituados ao sinal sonoro e as pessoas cegas e idosas de início não confiem neles para uma travessia independente e segura, é preciso que os sinais sejam instalados. Só assim a mudança terá início e se poderá exigir dos motoristas o respeito ao pedestre dependente do sinal.

Em 2009, a Companhia de Engenharia de Tráfico - CET desenvolveu um projeto-piloto visando diminuir o número de atropelamentos de idosos na cidade de São Paulo. Dados de 2010 da própria CET apontam que foram registradas 630 mortes por atropelamento na cidade, sendo 36\% delas de pessoas com mais de 65 anos. Idosos apresentam problemas com equilíbrio, dificuldade de locomoção, diminuição de audição e visão, fatores que contribuem para a dificuldade da travessia em segurança.

Matéria do jornal O Estado de Sáo Paulo ${ }^{23}$ cita medidas adotadas pela CET na Avenida Jabaquara, São Paulo, em frente às farmácias, locais de travessias frequentes de idosos. A autora do projeto é a gestora de trânsito da CET Telma Gorgulho Micheletto. Entre as medidas adotadas estáo o aumento do número de faixas de pedestres e a adequação de calçadas e rampas.

O tempo de duração do sinal verde para a travessia também faz parte das medidas adotadas. Programados para atender pessoas que caminham 1,2 metro por segundo, a maioria dos semáforos não atende aos idosos que caminham 0,65 metro por segundo. Segundo a gestora de trânsito, o que dificulta a adaptação das vias é a necessidade de garantir o fluxo de veículos. Pronunciando-se a esse respeito, o diretor da Associação Brasileira de Medicina de Tráfego - Abramet, Dirceu Rodrigues Alves Junior, critica as políticas públicas que privilegiam veículos e não pedestres. 


\section{Banheiros públicos}

Ao entrar em um banheiro público, a pessoa cega que não conta com um guia vidente para ajudá-la naquele momento, não encontra outra alternativa senão usar o tato para entender a planta do local e a maneira como o banheiro foi projetado. Mas como encontrar o mictório masculino, o papel, as pias, o sabonete, evitando o desconforto de tatear as peças de um banheiro público?

$\mathrm{Na}$ impossibilidade de manter um padrão para a construção desses banheiros, alguns recursos poderiam ser desenvolvidos para o entendimento do local. $\mathrm{Na}$ parede junto à porta de entrada, um mapa tátil simples, mostrando a planta baixa do local teria enorme serventia. Para banheiros masculinos, marcação tátil para os pés determinaria a localização exata à frente do mictório. Comum a todos, ao lado oposto à parede de entrada, uma parede com revestimento acústico, diferente do azulejado que reverbera o som, serviria de apoio extra à orientaçáo.

Banheiros públicos são importantes e devem estar disponíveis nas áreas de maior circulação de pessoas. Idosos, cadeirantes e outras pessoas com deficiência têm necessidade de usar o banheiro com maior frequência. No Metrô de Sáo Paulo, os banheiros são trancados com chave e só podem ser usados com o acompanhamento de um funcionário. Ou seja, o usuário tem que passar pelo constrangimento de pedir licença para ir ao banheiro. O funcionário tem que se deslocar com a chave, isso quando pode abandonar o seu posto.

Sabemos que não é fácil manter banheiros públicos limpos e seguros, mas esse é outro problema que envolve educação, fiscalização, verba para contratação de funcionários. Os cidadãos não podem sair às ruas na dependência de usar um banheiro de lanchonete, ou de qualquer outro estabelecimento comercial que faça (ou náo) a gentileza de recebê-lo.

\section{Os elevadores e a identidade dos andares}

As Normas Brasileiras de Acessibilidade da Associação Brasileira de Normas Técnicas - ABNT, no item elevadores, (NBR-13994) ${ }^{24}$ determina que os botôes das cabines tenham marcação em braille (5.1.8.3). Realmente, já podemos encontrar em muitas cidades brasileiras elevadores com comunicação em braille. As normas determinam também que haja identificação do pavimento, afixada nos batentes das portas, em cada andar (5.1.16.1). No entanto, esta norma não é cumprida em $100 \%$ dos edifícios visitados por nós, o que acarreta grande transtorno para as pessoas cegas.

A pessoa com deficiência visual que usa o elevador, desacompanhada de uma pessoa vidente, se conhecer a escrita braille pode reconhecer com independência o botão do andar para onde quer se dirigir. 
No entanto, quando o elevador para, só é possível identificar se aquele é o seu andar de destino quando há marcação na porta ou na soleira da porta. Sem a marcação, a pessoa corre o risco de descer em outro andar.

A identificação dos pavimentos é simples e barata e pode ser feita por qualquer pessoa com um mínimo de habilidade manual. Apesar de ser considerada necessária, há síndicos que alegam falta de recursos para a instalação dos números. $\mathrm{O}$ argumento não procede, já que nas lojas de materiais de construção, números de metal ou plástico custam entre $\mathrm{R} \$ 1,80$ e $\mathrm{R} \$ 5,50^{25}$. A marcação em braille tem praticamente custo zero e pode ser feita com fitas plásticas ou material reciclado, até mesmo pelo próprio morador cego. Percebe-se assim que se trata de uma questão de atitude, e não de falta de verba.

O ideal, segundo a protagonista Roseli, é que todos os elevadores tenham aviso sonoro, tanto de chegada quanto de identificação de andar. Ainda assim, a instalação de números continua necessária para atender às pessoas com deficiência auditiva. É importante também que as condiçóes do lugar permitam a percepçáo do som do elevador. Segundo depoimento de Toni Eames, protagonista norte-americana residente em Fresno, California, USA, o elevador do saguão de entrada da prefeitura daquela cidade fica ao lado de um lago. Pessoas cegas que aguardam o elevador náo percebem o ruído sutil do elevador devido ao ruído forte da cascata. Toni já encontrou o mesmo problema em um hotel no qual se hospedou e comenta o transtorno que o ruído causa.

\section{Espaços para estar e conviver; cidade e campo; pontos de referência}

\section{Interação e convivência}

Locais de observaçáo de pássaros, recantos de meditação, espaços para se ouvir sons diversos, concha acústica para apresentaçóes musicais, pavimento para caminhadas, quadras para esporte, labirinto de arbustos, relógio de sol, espaços para contemplação, para aulas de jardinagem e cuidados com o meio ambiente, pistas de jogo de bocha, bancos e cadeiras para tricotar e conversar, locais para simplesmente se estar.

Muitas vezes, idosos e outras pessoas com limitaçôes sentem-se confinados em casa por não terem opçóes de espaços que os recebam. $\mathrm{O}$ isolamento interfere na autoestima, provoca depressão, exclui do convívio. A cidade deve oferecer locais para onde o cidadáo possa ir apenas para estar com outras pessoas, conversar, ler, perceber e ser percebido, interagir, passear. É importante que a cidade propicie áreas de estar para toda a comunidade, promovendo a interação, independente de consumo. 
Nas cidades do litoral, as praias cumprem a função de prover espaço de convivência para todas as classes sociais, indistintamente. Em São Paulo, ao contrário, os espaços podem descriminar: supermercados diferenciados ou áreas de compras de produtos mais caros e shopping center sofisticados recebem apenas pessoas que têm acesso àqueles bens. Pessoas com baixo poder aquisitivo sequer frequentam esses locais, atendo-se a estabelecimentos mais simples, com ofertas de preços populares, próximos às residências e frequentados por pessoas de menor poder aquisitivo.

Locais de estar, que convidam ao encontro, devem ser inclusivos e acessíveis a todos. Nesse sentido, os parques e jardins podem se prestar muito bem a passeios, contemplaçáo e convivência. Temos bons exemplos nos jardins de Londres. Se desenharmos uma circunferência tendo o British Museum ao centro, em um perímetro de poucas quadras temos: Russell Square, Bloomsbury Square, Bedford Square, Malet Street Gardens, para citar apenas os parques maiores. Segundo a escritora Helene Hanff, autora do delicioso romance "84, Charing Cross Road"26 e apaixonada por Londres, há naquela cidade inúmeros jardins do tamanho de um lenço.

Thomas Jefferson tinha como ideais as cidades que alternassem um quarteirão edificado e outro com área verde ${ }^{27}$. Em Sáo Paulo, inúmeras áreas abandonadas e mesmo terrenos de propriedade da prefeitura podem ser aproveitados para espaço de lazer, criação de jardins ou hortas comunitárias, mesmo que temporariamente. O chefe de gabinete da Secretaria Municipal do Verde e do Meio Ambiente, Carlos Fortner, em entrevista para o jornal O Estado de Sáo Paulo ${ }^{28}$ ressalta que a prefeitura planta em média 200 mil árvores por ano. Informa que, dos 35 parques que havia em 2005, houve um aumento para 81 em 2012. Esses jardins estão sendo criados em áreas da periferia, onde os terrenos têm custo mais baixo. Mas, é impossível criar jardins em bairros onde o custo do terreno é alto, diz ele ${ }^{29}$.

Nos bairros mais tradicionais de uma metrópole como São Paulo, repetidamente, antigas residências são demolidas para dar espaço a prédios de muitos andares e nunca a uma pequena praça. É de conhecimento de todos que a administração urbana encontra no orçamento as suas limitaçóes, mas para frequentar um grande parque na capital, a maioria dos cidadãos depende de transporte, tão distantes

26 HANFF, Helene. 84, Charing Cross Road e A Duquesa de Bloomsbury. Casa Maria, 1988

27 RYKWERT, Joseph. A sedução do lugar. São Paulo : Martins Fontes, 2004, p. 14

28 Temperatura entre bairros de São Paulo varia até $14^{\circ} C$. O Estado de São Paulo, Caderno Metrópole, 26/03/2012

29 No bairro de Moema, em São Paulo, no início do lado ímpar da Rua Juriti, um terreno vazio da prefeitura incomoda os vizinhos pela falta de manutenção. $\mathrm{O}$ abandono do local é motivo de frequentes reclamaçóes dos moradores do entorno. Na Vila Clementino, um terreno da prefeitura está à venda na Rua Pedro de Toledo, o que tem causado protesto e revolta dos cidadãos do bairro, que preferem que no local seja construído um centro de convivência para idosos. 
estão essas áreas de seus frequentadores. Pequenas praças distribuídas por toda a cidade, ao contrário, estimulam intimidade com o local, fazendo com que o cidadão sinta-se parte da cidade, crie laços de amizade, exponha-se e interaja com outros cidadãos. Para pessoas com e sem deficiência, a exposição é importante para criar intimidade, possibilidade de interação e consequente quebra do estranhamento.

Áreas verdes têm também a função de baixar a temperatura. A mesma matéria cita pesquisa da Universidade Estadual Paulista, UNESP ${ }^{30}$, em colaboração com o laboratório Goddard, da Nasa, que aponta a gritante diferença de temperatura entre bairros da capital, que chega a variar em $14^{\circ} \mathrm{C}$. A geógrafa Magda Lombardo, autora da pesquisa, lembra que na cidade de Nova York, que tem mais áreas verdes, a diferença não passa de $6^{\circ} \mathrm{C}$. Em São Paulo, poucos quilômetros podem fazer diferença, como a apresentada entre a alta temperatura da Sé e a mais amena do bairro de Santa Cecília, mais arborizado. A criação de pequenos parques e jardins, em todos os bairros da capital, da periferia e da Grande São Paulo, certamente diminuiria as "ilhas de calor" e aumentaria a umidade do ar.

Em cidades de vários países encontramos espaços públicos diferenciados para convivência. $\mathrm{Na}$ China, áreas de estar são construídas sobre estacionamentos subterrâneos. Os espaços incluem cadeiras e bancos, diferenças de níveis, vegetaçáo, espelho d'água, extensóes abertas e áreas mais protegidas para aconchego. Um bom exemplo é o de Suzhou Creek, projeto do Studio BAU ${ }^{31}$. Em São Paulo, essas áreas poderiam ser construídas sobre os estacionamentos subterrâneos que servem estaçóes de Metrô. Infelizmente, ainda há poucos deles e matéria do jornal O Estado de São Paulo ${ }^{32}$ aponta que o Metrô da cidade desistiu de ampliar o número de estacionamentos integrados às estaçóes da rede, por não considerar prioridade - há apenas seis estacionamentos, que foram inaugurados entre 2009 e 2010.

\section{Cidade e campo - agricultura em área urbana}

Com a distribuição gratuita de sementes e mudas, os cidadãos podem ser estimulados a plantar e fazer a manutenção de canteiros próximos às suas casas. A atitude aproxima as pessoas, desperta afeto pelo local, estimula postura de cuidado com o meio ambiente, ensina as crianças, ajuda no fomento ao embelezamento da cidade. Encontros para a distribuição de sementes, bulbos, mudas podem se tornar eventos positivos e gratificantes. A jardinagem é uma atividade terapêutica que pode ser praticada por aposentados, pessoas idosas, com ou sem deficiências, crianças, pessoas em cadeiras de rodas.

30 http://www.unesp.br/aci/jornal/203/ilhas.php - visitado em 26/03/2012

31 www.bau.com

32 Lotação faz Metrô de SP desistir de criar estacionamento. O Estado de São Paulo, Caderno Cidades, 16/07/2012 
No norte da Inglaterra, iniciativa de duas donas de casa deu início a um grande projeto que embeleza a cidade, recupera áreas abandonadas e produz alimentos de graça para a comunidade. Todmorden, uma pequena cidade com 11 mil habitantes, aproveita seus espaços públicos para plantio de vegetais. Nos jardins da delegacia, no corpo de bombeiros e até mesmo no cemitério crescem milho, cebola, couve, temperos.

A iniciativa que teve início no jardim da igreja, seis anos mais tarde está recuperando até mesmo as fontes d'água que já tinham secado e trazendo de volta abelhas e borboletas. A prefeitura incentiva o plantio em espaços públicos e os cidadãos plantam e colhem vegetais livres de agrotóxicos em qualquer espaço disponível, seja em parques, ruas, terrenos baldios. O projeto é conhecido como Incredible Edible $e^{33}$ e cita: "Somos pessoas apaixonadas trabalhando juntas por um mundo onde todos dividem responsabilidade para o futuro bem-estar do planeta e de todos nós."

\section{Pontos de referência}

Segundo JACOBS (2000, p. 427), pontos de referência são indicaçóes de orientação e têm a função de enfatizar a diversidade e trazer reconhecimento para áreas da cidade. Pontos de referência são úteis também como pontos de encontro. Há muitos anos, as pequenas cidades do interior tinham na praça do coreto um ponto de encontro e lazer onde, aos domingos, tocava a banda. Usava-se também como referência a rua do cartório, a sorveteria, a fonte luminosa, o prédio do correio, locais pelos quais se desenvolve afeto, espaços que dáo sentido ao lugar. Estes são os espaços onde se marca encontros, onde se deseja estar. As metrópoles, repletas de cidadãos anônimos, anseiam por pontos de encontro para a interação: "te espero na praça, em frente ao relógio". Em Londres, na entrada da estação de Saint Pancras há uma estátua de nove metros de altura de um casal abraçado. A escultura do artista inglês Paul Day, chamada The Meeting Place, é usada como ponto de encontro.

Segundo Rykwert (2004, p. 185), um marco, um ponto de referência é um lugar que se sobressai, que desempenha um papel na vida da cidade, como o prédio da prefeitura ou o do mercado. Pontos de referência podem ser uma simples marcação de textura diferente no piso, mas também esculturas, jardins, monumentos, fontes de água, espaços de descanso, jardins comunitários, pontos para estacionamento de bicicletas, brinquedos criativos para adultos e crianças, entre outros.

As cidades burguesas do século XIX, cita o autor, tinham seus locais de encontro nas tavernas, restaurantes, bares, cafés. Já no século XX esses pontos foram reduzidos e restaurantes transformados 
em franquias vendendo as mesmas refeições rápidas, compostas de batata, hambúrguer, pizza, frango, refrigerante. Com pratos e talheres descartáveis e decoração com cores fortes, "a natureza homogeneizada das franquias de refeiçóes rápidas resulta em instalaçóes que não guardam relação alguma com sua localização e que não podem servir como pontos de referência marcante [...]” (RYKWERT, 2004, p187).

\section{Uma cidade ubíqua : U-City - A cidade interligada}

$\mathrm{O}$ governo coreano está destinando verba de $\mathrm{R} \$ 80$ bilhóes para construir uma nova cidade em um terreno de seis quilômetros quadrados próximo ao Mar Amarelo. Songdo será uma cidade wireless, onde o cidadão poderá, por exemplo, acompanhar o trajeto do lixo reciclável, da sua origem ao destino e ainda receber bônus por dispor o reciclável em local próprio. O fluxo do trânsito será monitorado por sensores instalados no asfalto, assim como o piso de uma casa poderá acionar um pedido de ajuda em caso de queda de um morador idoso. Uma cidade totalmente conectada, com hospitais, residências, empresas, órgãos públicos compartilhando dados. Chips enviando informaçóes para notebooks e telefones celulares, informando sobre vagas para estacionamento, horários de eventos culturais e desportivos, previsáo do tempo.

Os avanços tecnológicos facilitam a vida das pessoas com deficiência, sendo um dos mais importantes os sintetizadores de voz, que permitem o uso do computador por pessoas com deficiência visual. Nas cidades, as novas tecnologias facilitariam a identificação do transporte urbano, por exemplo, com sensores capazes de indicar, para a pessoa que espera no ponto, a aproximação do transporte aguardado.

Em São Paulo, um novo serviço da São Paulo Transportes, SP Trans ${ }^{34}$, teve início em 26/03/2012, disponibilizando na Internet o deslocamento dos ônibus em tempo real. O site informa horário de ônibus em seis dos dez corredores exclusivos para ônibus, com acerto de 96\%, segundo Maurício Lima Ferreira $^{35}$, diretor de Tecnologia da empresa.

Lembro que o serviço encontra-se disponível apenas para computadores e telefones celulares Smartphone, com sistema operacional Android. A comunicação é visual, com imagem que aponta em um mapa pequenos balóes referentes aos ônibus que estão em movimento. Ou seja, não atende à pessoa cega, como o próprio nome indica (Olho Vivo). Desejado seria que o recurso estivesse disponível no próprio ponto de ônibus, com a relação dos ônibus e seus horários impressa em braille e em áudio. A instalação de um chip com recurso de áudio poderia identificar quando o ônibus se aproxima, avisando quem está

34 http://olhovivo.sptrans.com.br/

35 Celular dá horário de ônibus na capital. O Estado de São Paulo, Caderno Cidades, 26/03/2012 
$\because \because \because \because \because \because \because \because \because \because \quad \because \because \because \because \because \because$

à espera e não é capaz de ler o letreiro identificador no topo do ônibus.

Muitas das linhas de ônibus já não têm cobrador e pessoas cegas ou com baixa visão dependem do motorista ou de um vidente para avisar da chegada do ponto em que vão descer. O ônibus poderia contar também com recurso de áudio, como o existente no Metrô, que anuncia a próxima parada e identifica a chegada.

Nesse sentido, parceria com as universidades estimulariam o desenvolvimento de novos projetos para atender as necessidades da população com deficiência, por exemplo, pessoas que dependem de audiodescrição poderiam receber boletins diários de programação em seus aparelhos de telefone celular. E as etiquetas de supermercado possibilitariam leitura e identificação, para que a pessoa cega pudesse fazer suas compras com independência.

Em São Carlos (SP), desde o início do mês de julho deste ano, um aplicativo instalado nos telefones celulares facilita o deslocamento de pessoas cegas que usam o transporte público ${ }^{36}$. Segundo o Grupo Criar, responsável pelo programa, o sistema encomendado pela prefeitura é inédito no país e o único custo para o usuário é o de envio de uma mensagem de texto para possibilitar o recebimento de um link.

Depois de instalar o aplicativo no seu telefone celular, o passageiro cego digita no telefone o número do ônibus e o número do ponto em que espera a condução. Já no veículo, o usuário digita o número do ponto de destino. Em gravação de áudio, o passageiro recebe informaçóes de localização e tempo estimado até o local de desembarque. Nos 40 pontos de ônibus mais usados por pessoas com deficiência visual também foram instaladas numeração em braille e em relevo.

\section{Qualidade de vida - açóes}

A interação entre os cidadãos e os seus representantes estimula açóes de conservação e a criação de soluçóes para a melhoria do espaço urbano. A prefeitura poderia disponibilizar um canal para que o cidadão desenhasse o seu bairro conforme as suas necessidades e aspirações. Em Nova York, por exemplo, desde 2010 os cidadáos contam com um site de patrocínio colaborativo ${ }^{37}$ e que já conseguiu aproximadamente US\$200 mil em doaçóes para desenvolver projetos em diferentes áreas da cidade.

Os projetos são simples como limpeza de lotes abandonados, manutenção de calçadas, compostagem, reciclagem, criação de espaços abertos e verdes, e também mais complexos, como o gerenciamento do sistema de esgotos, limpeza do ar e da água. Há moradores usando áreas abandonadas no entorno de suas residências para a criaçáo de galinhas e plantio de hortas.

36 Celular avisa cego que ônibus chegou ao ponto em São Carlos (SP). Jornal Folha de São Paulo, 11/07/2012,

37 www.ioby.org - visitado em 03/2012 
Ideias singelas podem trazer melhorias para a qualidade de vida. Em Los Angeles, a prefeitura investiu US\$26 milhóes na recuperação de uma antiga garagem de ônibus que estava abandonada. O local foi transformado em parque aberto, com pântanos naturais, voltado à preservação.

\section{Lazer no centro antigo}

A principal paisagem da cidade é constituída pelas suas ruas, espaço de vida intensa e que acolhe diferentes atividades. As zonas antigas da cidade têm traçado irregular (JACOBS, 2007). Esse traçado pode criar espaços de mais intimidade quando, aos domingos, o movimento comercial desaparece. É nessas manhãs que os moradores da região passeiam com seus cachorros, nas ruas de comércio vazias do burburinho do horário comercial da semana.

No Bairro do Bom retiro, a Rua José Paulino, tradicional pelas lojas de preços populares, é uma das ruas que ficam desertas nas tardes de domingo. O local é interessante para ações de lazer e cultura que podem ser desenvolvidas na própria rua, praticamente sem movimento de carros. Cursos de artesanato, música ao vivo, pintura de fachada de casas antigas, limpeza, reciclagem, plantio de árvores, há uma infinidade de açóes que podem despertar afeto pelo lugar e transformar a rua em ponto social.

Para aquela região, onde cresce a atividade de comerciantes orientais e, depois do português, os idiomas mais falados atualmente são o mandarim e o cantonês ${ }^{38}$, encontros para aulas de português para estrangeiros, conversação, seria proveitoso para a aproximação e intercâmbio entre as diferentes culturas.

Especialmente para pessoas cegas, apresentar a arquitetura antiga do centro histórico também pode ser uma atividade muito interessante. $\mathrm{O}$ contraste de fachadas antigas, características de época, com as frentes envidraçadas de bancos, por exemplo, são instigantes para o tato e comunicam com conceitos muitas vezes desconhecidos para pessoas cegas que anseiam por visitar o centro com alguém que possa lhe passar essas informaçóes.

Para as crianças, as ruas de lazer também têm grande valor. A aposentada Dirce Vieira, com 81 anos, com muito esforço conseguiu criar a primeira rua de lazer na cidade de São Paulo. Trata-se da Rua Manoel Faria Inojosa, em São Miguel Paulista, na Zona Leste. Em 1977, depois de 12 anos insistindo com a prefeitura, ela conseguiu que a rua permanecesse fechada aos domingos e feriados para o lazer das crianças do bairro.

Hoje já há 1.245 ruas de lazer na cidade, segundo matéria do jornal O Estado de São Paulo ${ }^{39}$. É

38 Comerciantes tradicionais perdem espaço e 25 de março vira “Chinatown”. O Estado de Sáo Paulo, Caderno Metrópole, 12 de agosto de 2012.

39 Ela só queria uma rua para os filhos brincarem. O Estado de São Paulo, Caderno Metrópole, 25/03/2012 
necessária a aquiescência de no mínimo $70 \%$ dos moradores, e um trâmite protocolar encaminhado à subprefeitura mais próxima. A placa de "Rua de Lazer" é fornecida pela Companhia de Engenharia de Tráfego - CET. Segundo a pedagoga Silvia de Mattos Gasparian Collello, pesquisadora da Universidade de São Paulo, "esse tipo de iniciativa é muito importante em cidades como São Paulo, onde o espaço doméstico está cada vez menor”.

\section{Espaços diferenciados nas cidades}

Um dos problemas presentes nas metrópoles é o aumento demográfico. As dificuldades decorrentes do adensamento da populaçáo passam a sobrecarregar o sistema de infraestrutura urbana e seus subsistemas. Equipamentos sociais urbanos têm papel importante na qualidade de vida da população, as cidades são construídas para as pessoas, e são elas que fazem a cidade.

$\mathrm{O}$ site CityMart ${ }^{40}$ é uma plataforma que conecta cidades que apresentam boas e criativas soluçóes urbanas. Unindo profissionais de todo o mundo, apresenta uma relação de açóes para intensificar a qualidade de vida das cidades. Soluçóes como áreas comunitárias, troca de ideias sobre eventos, espaços e serviços, indicação de ruas onde se caminha com prazer, iluminação inteligente para cidades e dezenas de outras ideias nos tópicos de transporte, turismo, administração, lazer, segurança, eventos, sustentabilidade, mobilidade, comunidade, meio ambiente, entre outros.

Há bons exemplos de criativas soluçôes urbanas em espaços públicos, que propiciam experiências diferenciadas e agradáveis. Em Zadar, na Costa da Croácia, foi construído um espaço que tem como característica principal um conjunto de tubos por onde entra o ar, empurrado pelo movimento do mar. Conhecido como Órgão do $\mathrm{Mar}^{41}$, a montagem emite sons agradáveis e propicia prazer aos visitantes. Outro exemplo é a Singing Ringing Tree, uma escultura de tubos construída em área rural no Crown Point em Burnley Council, Inglaterra ${ }^{42}$, que emite sons diferenciados provocados pelas correntes de vento. Sáo esculturas sonoras em espaços de convivência e contemplaçáo que agregam prazer e significado à vida nas cidades.

Katia Canton, curadora do Museu de Arte Contemporânea da USP, diz que "há um novo conceito de arte pública ancorada na melhoria da vida das pessoas [...]. A ideia de arte pública apenas para

40 http://citymart.com

41 http://www.croatia.org/crown/articles/9359/1/Nikola-Baiae-author-of-the-Zadar-Sea-Organ.html

42 http://www.burnley.gov.uk/site/scripts/news_article.php?newsID=12561 
a questão retiniana está esgotada”. Artigo do jornal O Estado de São Paulo ${ }^{43}$ noticia reunião de comitê internacional, em maio, na China, que dentre 100 projetos selecionou 20 obras candidatas ao Prêmio Internacional para Excelência em Arte Pública. O concurso é promovido pela Universidade de Xangai e o vencedor será conhecido em novembro de 2012.

As cidades pedem novas soluçóes para novos problemas. Desde 2009, o Living Labs Global Award 2012 - LLGA $2012^{44}$ trabalha com cidades da Europa, Ásia, África e Américas na busca de soluçóes para problemas urbanos. Um encontro em maio de 2012 no Rio de Janeiro reuniu os 21 vencedores das melhores soluçóes e inovaçóes de serviços para cinco áreas: mudanças climáticas, turismo e mobilidade, sistemas e serviços urbanos, saúde e bem-estar, open governament e acessibilidade.

\section{Termo de referência}

Cada um de nós guarda características próprias, como a textura da pele, a temperatura do corpo, o odor que emana, o tom da voz, o ritmo do movimento, da conversa. Assim como nós, tudo o que nos rodeia também tem textura própria, reverbera sons, mantém a temperatura, exala, acolhe, repele.

As pessoas diferem umas das outras, são lentas ou calmas, rápidas, nervosas, quietas, inquietas. A riqueza está na diversidade. E essa diversidade pode também ser usada para enriquecer os ambientes. Materiais diferentes que surpreendem, pisos que estabelecem ritmos e transmitem conceitos, ambientes pequenos que aconchegam, ou mais amplos que libertam. Revestimentos que guardam para si a nossa voz, formas que acolham nossas mãos, nosso corpo. Corredores por onde o vento possa transgredir e tocar a nossa pele, nos arrepiar, alternando pontos que nos aqueçam. Ambientes internos e externos podem ser criados para provocar sensaçóes, podendo ser dramáticos, quentes ou frios, calmos, macios.

Não contemos apenas com a visão, ela não é tudo. No escuro, o recurso nem mesmo existe. Náo esperemos o apagar das luzes para considerar o tato. O tato, e todos os outros sentidos, estão aqui, agora, à disposiçáo para serem percebidos. E, se houver dificuldade para esse entendimento, pessoas cegas podem servir de guias no aprendizado. Para tanto, basta que elas sejam consideradas como cidadáos que têm algo a ensinar.

43 Nova arte pública. O Estado de Sáo Paulo, Caderno 2. 12/07/2012

44 http://llga.org - Visitado em 03/2012 
Existem os bens passíveis de posse individual e os que devem ser compartilhados por todos. A comida e a roupa de um homem não são a comida e a roupa de outro homem; se a oferta é insuficiente, aquilo que um homem possui é obtido a expensas de outros. Isto se aplica em geral aos bens materiais e, por conseguinte, à maior parte da vida econômica do mundo atual. Os bens mentais e espirituais, por outro lado, não pertencem a um homem em prejuízo de outros. Um homem conhecer uma ciência não impede que outros também a conheçam; ao contrário, os ajuda a adquiri-la. Ser um grande artista ou um poeta não impede que outros pintem quadros ou escrevam poemas, ajuda a criar a atmosfera na qual essas coisas são possíveis. Ser pleno de boa vontade para com alguns náo significa que reste menos boa vontade para ser compartilhada com os demais; quanto mais boa vontade tenha um homem, com mais probabilidade ele a criará entre os outros. Em tais questóes não existe posse, porque não existe uma quantidade determinada a ser dividida; qualquer acréscimo em qualquer lugar tende a produzir outros em todos os lugares.

RUSSEL, Bertrand. Ideais politicos, 1917 Editora Bertrand Brasil, 2001, p. 1 



\section{REFERÊNCIAS}

ABREU, Elza Maria de Araujo Carvalho et al. Braille!? O que é isso? São Paulo : Fundação Dorina Nowill para Cegos, 2008 ACKERMAN, Diane Uma história natural dos sentidos. Rio de Janeiro : Bertrand Brasil, 1992

ADORNO, T. W. et al. Cultura e sociedade. Lisboa : Editorial Presença, 1970

AMARAL, Lígia A. Pensando a deficiência como diferença. III Congresso sobre Educação Especial. Curitiba, 1999 . Resgatando o passado - deficiência como figura e vida como fundo. São Paulo : Casa do Psicólogo, 2004

APROBATO FILHO, Nelson. Kaleidosfone.: as novas camadas sonoras da cidade de São Paulo. São Paulo : EDUSP : FAPESP, 2008

ASHIHARA, Yoshinobu. Exterior design in architecture. New York : Van Nostrand Reinhold,1970

AUGÉ, Marc. Não-lugares: introdução a uma antropologia da supermodernidade. Campinas, SP : Papirus, 1994

AUSTIN, J. L. Sentido e percepção. São Paulo : Martins Fontes, 1993

BACHELARD, Gaston. A poética do espaço. São Paulo : Martins Fontes, 1993

BAKEWELL, Sarah. How to live or A life of Montaigne. New York : Other Press Ed, 2010

BARROS, Manoel de. O livro das ignorãnças. Rio de Janeiro : Record, 2007

. Poemas Rupestres. Rio de Janeiro : Record, 2007

Gramática expositiva do chão. Rio de Janeiro : Editora Civilização Brasileira, 1992

BENJAMIN, Walter. O narrador - Consideraçôes sobre a obra de Nikolai Leskov. Magia e técnica, arte e politica - Ensaios sobre literatura e história da cultura. São Paulo : Brasiliense, 1985 
BLOOMER, Kent C; MOORE, Charles W.; YUDELL, Robert J. Body, memory and architecture. New Haven : Yale University Press, 1977

BOBBIO, Norberto. Elogio da serenidade e outros escritos morais. São Paulo : Editora UNESP, 2011

BORRÀS, Maria Lluïsa. Arquitectura Finlandesa. Barcelona : Ediciones Polígrafa S.A.

BOSI, Ecléa. O tempo vivo da memória. Cotia : Atelier Editorial, 2004

Memória e sociedade - lembranças de velhos. São Paulo : T. A. Queiróz, 1979

BOTTON, Alain de. The architecture of happiness. New York : Vintage, 2006

BOURDIEU, Pierre. Coisas ditas. São Paulo : Brasiliense, 2004

BRILLAT-SAVARIN. A fisiologia do gosto. Rio de Janeiro : Salamandra, 1989

BULL, Michael; BACK, Les - editor. The auditory culture reader. Oxford : Berg, 2003

BUSTOS, Carolina. Condiçôes de percepção e deslocamento dos usuários com deficiência visual. Mestrado, UFRGS, Escola de Engenharia. Porto Alegre, 2004

CALVINO, Italo. Cidades invisiveis. São Paulo : Companhia das Letras, 1990 Seis propostas para o próximo milênio. São Paulo : Companhia das Letras, 1990

CARROL, Reverendo Thomas J. Cegueira - o que ela é, o que ela faz e como viver com ela. São Paulo : MEC. Campanha Nacional de Educação dos Cegos, 1968

CERTEAU, Michel. A invenção do cotidiano. Petrópolis : Vozes, 1994

CHEVIGNY, H. My eyes have a cold nose. New Haven : Yale University Press, 1962

CLASSEN, Constance. Aroma. Rio de Janeiro : Zahar Editores, 1996 . Editor. The book of touch. Sensory Formations Series. New York : Berg, 2005

COATES, Gary J. Seven principles of life-enhancing design - The architecture of Erick Asmussen. International Academy for Design and Health. p. 239-254. Disponível em http://74.125.47.132/search?q=cache:47kgF8VbFgwJ:www. designandhealth.com/edu_res/Gary\%2520J.\%2520Coates\%2520p239.pdf+goethe+life-enhancing\&cd=8\&hl=ptBR\&ct $=$ clnk\&gl=br.

COLEÇÃO NOSSO SÉCULO. Memória fotográfica do Brasil-Século XX. São Paulo : Abril Cultural, 1980

CONDILLAC, Étienne de.Tratado das sensaçôes. Campinas : Editora da UNICAMP, 1993

CONFUCIO. Os anacletos. São Paulo : Martins Fontes, 2005

CONSTANTINO, Regina Maria. Uma ecologia para o som em: Quem tem medo do interior? Londrina : Editora UEL, 2001

COOK, D. Impact of disability on the individual. Parker, R.M., HANSEN, C.E.: Reabilitation Counseling. Boston, Allyn and Bacon Inc., 1989.

COPPOLA, A, F. Reality and the Hapic World. Phi Kappa Phi Journal, Winter, 1970 


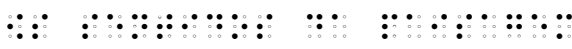

CORALINA, Cora. Dos becos de Goiás e histórias mais. Rio de Janeiro : Global Editora, 1983

CRATTY, Bryant J.; SAMS, Theressa A. The body-image of blind children. New York : The American Foundation for the Blind, 1968

CROCHÍK, José Leon. Preconceito, individuo e cultura. São Paulo : Robe, 1995 (org). Perspectivas teóricas acerca do preconceito. São Paulo : Casa do Psicólogo, 2008

CULLEN, Gordon. The concise townscape. London : Architectural Press, 1978. . Paisagem Urbana. Lisboa : Edições 70, 1978

CUTSFORTH, Thomas D. O cego na escola e na sociedade. São Paulo : Campanha Nacional de Educação dos Cegos, 1969 Personality and social adjustment among the blind. ZAHL, p. : Blindness, Princeton University Press, 1950.

CYRULNIK, Boris. Do sexto sentido. São Paulo : Editora Piaget, 1999

DAMATTA, Roberto. A casa e a rua. São Paulo : Brasiliense, 1985

DANSEREAU, Pierre Mackay. A terra dos homens e a paisagem interior. Belém : NAEA/UFPA, 1999

DAY, R. H. Psicologia da percepção. Rio de Janeiro : José Olympio, 1970 Percepção humana. LTC Editora : Rio de Janeiro, 1972

DEMO, Pedro. Metodologia do conhecimento cientifico. São Paulo : Atlas, 2000.

DESCAMPS, C. Normal /anormal .In: Enciclopédia EINAUDI. Exclusão/integração. Edição Portuguesa: Imprensa Nacional - Casa da Moeda, vol. 23, 1994

DICKINSON, Emily. Uma centena de poemas. São Paulo : EDUSP, 1984

DIDEROT, Denis. Da interpretação da natureza e outros escritos. São Paulo : Iluminuras, 1989 Obras I - Filosofia e Politica; J. Guinsburg. Organização, Tradução e Notas. São Paulo : Perspectiva, 2000

DISCHINGER, M. Designing for all sens. Accessible spaces for visualy impaired people. Departament of Space and Process, Chalmers University of Technology, Göteborg, Sweden, 2000. Disponível em: http://www.geocities.com/HotSprings/7861/mente/mente163.html.

[et al.]. Passeios acompanhados. 60 ERGODESIGN. Bauru, SP : LEI FAAC UNESP, 2006

DOURADO, Autran. Uma vida em segredo - Rio de Janeiro : Rocco Editora, 2001

DROBNICK, Jim. Editor. The smell culture reader - Sensory Formations Series. New York : Berg, 2006

DUFRENNE, Mikel. Estética e filosofia. São Paulo : Perspectiva, 1972

EAMES, Ed and Toni. Partners in independence. New York : Howell Book House, 1997

ELIAS, Norbert. Os estabelecidos e os outsiders. Rio de Janeiro : Zahar, 2000

EPSTEIN, William; ROGERS, Sheena - editor. Perception of space and motion. San Diego, CA, USA : Academic Press, 1995 
FERRARA, Lucrécia D’Alesso. Olhar periférico. São Paulo : Edusp: FAPESP, 1993

FRAMPTON, Kenneth. Arquitetura moderna. São Paulo : Martins Fontes, 2003 Toward a critical regionalism: six points for an architecture of resistance.p.28. In: FOSTER, Hal (editor) Postmodern culture. UK : Pluto Press, 1985

FRANCK, Frederick. The zen of seeing - seeing and drawing as meditation. Vintage Books, 1973

GALBRAITH, John Kenneth. A sociedade justa - uma perspectiva humana. Rio de Janeiro : Campus, 1996

GEERTZ, Clifford. A interpretação das culturas. Rio de Janeiro : Zahar, 1978

GIBSON, James J. The senses considered as perceptual systems. Boston, USA : Houghton Mifflin Company, 1966

GOFFMAN, Erving. Encounters - two studies in the sociology of interaction. Bobbs-Merril, 1961.

Estigma. Notas sobre a manipulação da identidade deteriorada. Rio de Janeiro : Editora Guanabara, 1988

GREER, N.R. The state of art of design for accessibility. Architecture, Jan 58-61, 1987

GRIFFIN, Donald R. Echoes of bats and Men. Science Study Series. New York : Anchor Books, Doubleday, 1956

GRUNWALD, Henry. Twilight. Knopf : New York, 1999

GUIA DO ESTADO DE SÃO PAULO - Vol. 1. São Paulo : Conselho Nacional de Geografia, 1962

HALL, A. Mental images and the cognitive development of the congenitally blind. Journal of Visual Impairment and Blindness, September, 75, no 7, 1981

HALL, Edward T. A dimensão oculta. Lisboa : Relógio D’Água Editores, 1986

HANFF, Helene. 84, Charing Cross Road e A Duquesa de Bloomsbury. Casa Maria, 1988

84, Charing Cross Road. New York : Penguin Books, 1990

HAYNES, S. p. Contribuitions to a psycology of blindness, NY, American Foundation for the Blind, 1941

HILLMAN, James. Cidade \& Alma. São Paulo : Studio Nobel, 1993

HOLL, Steven; PALLASMAA, Juhani; PÉRES-GÓMEZ, Alberto. Questions of perception. San Francisco : William Stout Publishers, 2006

HULL, John M. On sight \& insight - a journey into the World of Blindness. Oneworld, 1997 Touching the rocks. Vintage, 1991

HUME, David. Investigaçóes sobre o entendimento humano e sobre os princípios da moral. São Paulo : Editora UNESP, 2004

JACOBS, Jane. Morte e vida de grandes cidades. São Paulo : Martins Fontes, 2000

JACQUARD, Albert. Elogio da diferença. São Paulo : Martins Fontes, 1988

KELLER, Helen. The world I live in. New York : Dover, 2009

. The story of my life. New York : Dover, 1996 


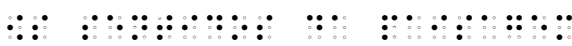

KISH, Daniel. Echolocation: how humans can see without sight-Sonic Echolocation: a modern review of the literature. Sobre a instituição: http://www.worldaccessfortheblind.org/

World Access for the Blind: http://www.waftb.org/annual-report-2003-6.pdf

KLEEGE, Georgina. Sight unseen. New Haven : Yale University Press, 1999

KUUSISTO, Stephen. Planet of the blind-a memoir. New York : Delta, 1999

LARAIA, Roque de Barros. Cultura é um conhecimento antropológico. Rio de Janeiro : Zahar, 1986

LEFEVRE, J. Eduardo Assis. A antropologia da metrópole moderna . Revista da FAPESP-PESQUISA : São Paulo, 2001 . De Beco a Avenida. São Paulo : Editora da Universidade de São Paulo, 2006

LE GOFF, Jacques. Por amor às cidades. São Paulo : Fundação Editora da UNESP, 1998

LENOBLE, Robert. História da idéia de natureza. Lisboa : Edições 70, 2002

LEVIN, David Michael - editor. Modernity and the hegemony of vision. Berkeley : University of California Press, 1993.

LIPAI, Alexandre Emilio. Arquitetura: percepçôes de uso do espaço e suas múltiplas realidades. Tese de Doutoramento - FAU/ USP 1993.

LISPECTOR, Clarice. Água viva. São Paulo : Círculo do Livro, 1973

Laços de família. Rio de Janeiro : Nova Fronteira, 1983

LOBELL, John. Between silence and light. Boston, MA. : Shambhala Publications, 1979

LORA, Tomásia Dirce Peres. Descobrindo o real papel das outras percepçóes, além da visão, para a orientação e mobilidade. P58. In: MACHADO. Edileine Vieira [et al.]. Orientação e mobilidade: Conhecimentos básicos para a inclusão do deficiente visual. Brasília: MEC, SEESP, 2003

LOWENFELD, V. , Brittain, W. L. Desenvolvimento da capacidade criadora. São Paulo : Mestre Jou, 1970

LUCRECIO - Titus Lucretius Carus. Da Natureza. Tradução de Agostinho da Silva. Porto Alegre : Editora Globo, 1962

LUCRETIUS - Titus Lucretius Carus. On the nature of things. Londres: The Great Books. Encyclopaedia Britannica, 1971. Original de 99-55bC : De Rerum Natura.

LUSSEYRAN, Jacques. Cegueira, uma nova visão do mundo. São Paulo : Associação Beneficente Tobias, 1983

LYNCH, Kevin. A imagem da cidade. São Paulo : Martins Fontes, 1980

MAGEE, Bryan; MILLIGAN, Martin. On blindness. New York : Oxford University Press, 1995

MASI, Ivete de. Conceitos : aquisição básica para a orientação e mobilidade. In: : MACHADO. Edileine Vieira [et al.]. Orientação e mobilidade: Conhecimentos básicos para a inclusão do deficiente visual. Brasília: MEC, SEESP, 2003

MASINI, Elcie F. Salzano (org.) A pessoa com deficiência visual. São Paulo : Vetor, 2007 . (org) Do sentido... pelos sentidos... para o sentido. São Paulo : Vetor Editora, 2002 O perceber e o relacionar-se do deficiente visual. Brasília : CORDE, 1994 
MAUSS, Marcel. Sociologia e antropologia. São Paulo : E.P.U: EDUSP, 1974

McHARD, Ian L. Design with Nature. Garden City, N.Y. : Published for the American Museum of Natural History [by] the Natural History Press, 1969

MELO, Helena Flávia R. Deficiência Visual : Liçóes Práticas de Orientaçâo e Mobilidade. Campinas : Editora da UNICAMP, 1991

MENEZES, Ulpiano Bezerra. A paisagem como fato cultural. In YÁZIGI, Eduardo (org). São Paulo : Contexto, 2002

MERLEAU-PONTY, Maurice. Fenomenologia da percepção. São Paulo : Martins Fontes, 1994

. Conversas - 1948. São Paulo : Martins Fontes, 2004

O visivel e o invisível. Sao Paulo : Perspectiva, 1971

O olho e o espirito. São Paulo : Cosac \& Naify, 1960

A dúvida de Cézanne. São Paulo : Cosac \& Naify, 1960

A estrutura do comportamento. Belo Horizonte : Interlivros, 1975.

. O primado da percepção. Campinas : Papirus, 1990.

. A Natureza. São Paulo : Martins Fontes, 2006

. O olho e o espírito. São Paulo : Cosac \& Naify, c. 2004.

METTLER, R. Blindness and managing the environment. Journal of Impairment and Blindness. December, 1987

MIKKOLA, Kirmo. Architecture in Finland in the 20th century. Finnish-American Cultural Institute, 1981

MONTAGU, Ashley. Tocar - o significado humano da pele. São Paulo : Summus Editorial, 1986

MONTE ALEGRE, Paulo Augusto Colaço. A cegueira e a visão do pensamento. Dissertação de Mestrado, Instituto de Psicologia, USP, 2003

MONTEIRO, Irineu. Helen Keller. São Paulo : Alvorada, 1982

MOTA, Maria da Gloria Batista (Coord). Orientação e Mobilidade - Conhecimentos básicos para a inclusão da pessoa com deficiência visual / Elaboração Edileine V. Machado...[et al.] - Brasília : MEC, SEESP, 2003

MORIN, Edgar. A cabeça bem-feita. Rio de Janeiro : Bertrand Brasil, 2001

NAVA, Pedro. Baú de ossos: memórias. Rio de Janeiro : José Olympio, 1974

NOVAES, Adauto (org). O olhar. São Paulo : Companhia das Letras, 1988

OKAMOTO, Jun. Percepção ambiental e comportamento. São Paulo : Plêiade, 1996.

OLIVEIRA, Aíla S.D.A. Acessibilidade espacial em centro cultural. Mestrado, Faculdade de Arquitetura de Urbanismo, Florianópolis : Universidade Federal de Santa Catarina, 2006

ORLANDI, Luis. (org). A diferença. Campinas : Editora da UNICAMP, 2005

PALLASMAA, Juhani. The eyes of the skin : architecture and the senses. West Sussex, UK : John Wiley : 2008 


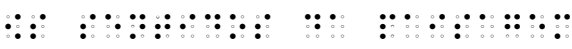

PESSOA, Fernando. Obra Poética. São Paulo : Companhia José Aguilar Editora, 1972

POEMS OF TO-DAY: First and Second Series. London : Published for the English Association by Sidgwick \& Jackson, Ltd. , 1924

PREISER, Wolfgang F. E. Design intervention - toward a more humane architecture. New York : Van Nostrand Reinhold, 1991.

PROUST, Marcel. Nos caminhos de Swann. Porto Alegre : Editora Globo, 1972

QUEIROZ, Marco Antonio. Sopro no corpo. São Paulo : Círculo do Livro, 1986

RAPOPORT, Amos. Human aspects of urban form. New York : Pergamon Press, 1977.

RASMUSSEN, Steen Eiler. Arquitetura vivenciada. São Paulo : Martins Fontes, 1986.

REIS FILHO, Nestor Goulart. São Paulo e outras cidades. São Paulo : UCITEC, 1994

RÉVÉSZ, Géza. The problem of space with particular emphasis on specific sensory spaces - Amsterdam Universiteit. The American Journal of Psychology, v. 50, 1937

RILKE, Rainer Maria. Where silence reigns : Selected prose. New York : New Directions, 1978

RIO, Vicente del; DUARTE, Cristiane Rose; RHEINGANTZ, Paulo Afonso. Projeto do lugar. Rio de Janeiro : Contra Capa Livraria / PROARQ, 2002

ROCHA, H. Ribeiro -Gonçalves, coord. Ensaio sobre a problemática da cegueira. Belo Horizonte : Fundaçáo Hilton Rocha, 1987

ROUSSEAU, J. J. Os devaneios do caminhante solitário. São Paulo : Hucitec, c1986

RYKWERT, Joseph. A sedução do lugar. São Paulo : Martins Fontes, c.2004

SÁ, Sérgio. Feche os olhos para ver. Barueri : Sá Editora, 2004

SACKS, Oliver. The man who mistook his wife for a hat. London : Picador, 1986

. Um antropólogo em Marte : sete histórias paradoxais. São Paulo : Companhia das Letras, 1995

. A ilha dos daltônicos. São Paulo : Companhia das Letras, 1997

. Vendo vozes. Rio de Janeiro : Imago Editora, 1990

O olhar da mente. São Paulo : Companhia das Letras, 2010

SAINT EXUPÉRY. Lettre à um otage. Èditions Gallimard, 1944.

. Terra dos homens. Rio de Janeiro : José Olympio Editora, 1983

SALGADO, Mauro I.; VALADARES, Eugênia R. Para compreender a deficiência. Belo Horizonte, Faculdade de Medicina da UFMG, 2000

SANDEVILLE, Euler. Paisagens e métodos. Algumas contribuiçóes para a elaboração de roteiros de estudo da paisagem intraurbana. In revista eletrônica da área Paisagem e Ambiente USP, 2004. Disponível em http://www.usp.br/fa/deprojeto/gdpa.

. Um roteiro para estudo da paisagem intra-urbana 2004 In revista eletrônica da área Paisagem e Ambiente USP 2004. Disponível em http://www.usp.br/fa/deprojeto/gdpa.

Paisagens são experiências partilhadas. São Paulo, 2004, inédito 
Paisagens. In revista eletrônica da área Paisagem e Ambiente USP 2006

SANTOS, Carlos Nelson F. (coord) Quando a rua vira casa. São Paulo : Ibam/finep, 1985

SANTOS, Milton . As cidadanias mutiladas. Em: O preconceito / Julio Lerner editor. São Paulo : IOE, 1996/1997

SARAMAGO, José. Ensaio sobre a cegueira. São Paulo : Companhia das Letras, 1995

SASSAKI, Romeu Kasumi. Inclusão: construindo uma sociedade para todos. Rio de Janeiro : WVA, 1997

SCHAIK, Leon van. Poetics in Architecture. John Wiley \& Sons Limited, 2002

SCHIFFMAN, Harley Richard. Sensação e percepção. Rio de Janeiro : LTC, 2005

SCHOPENHAUER, Arthur. O mundo como vontade e como representação. Editora UNESP : São Paulo, 2005

SEKKEL, Marie Claire et al. Educação inclusiva: percursos na educação infantil. São Paulo : Casa do Psicólogo, 2008

SENNETT, Richard. The conscience of the eye. Norton : New York, 1992

SCOTT, R. A. The making of the blind man: a study of adult socialization, New York : Russel Sage Foundation, 1969

SERPELL, Robert. Influência da cultura no comportamento. Zahar Editores : Rio de Janeiro, 1977

SPYRIDAKI, Georges. La Grèce et la poésie moderne, Paris, 1954

STAINBACK, Susan; STAINBACK, William. Inclusão. Porto Alegre : ArtMed Editora, 1999

STEINER, Rudolf. Os doze sentidos e os sete processos vitais. São Paulo : Antroposófica, 1997

STEPHEN, Stoer R. ; MAGALHÂES, António M ; RODRIGUES, David. Os lugares da exclusão social. São Paulo : Cortez, 2004

SILVA TELES, Armando. Imaginários urbanos. São Paulo : Editora Perspectiva, 2001

SIMMEL, Georg. O fenômeno urbano. Rio de Janeiro : Zahar, 1967

STOER, Stephen R. [et al.] Os lugares da exclusão social. São Paulo : Cortez, 2004

TENBERKEN, Sabriye. My path leads to Tibet. New York : Arcade Publishing, 2003

THOREAU, Henry D. Caminhando. José Olympio : Rio de Janeiro, 2006

Desobedecendo. Rio de Janeiro : Rocco, 1986

Walden ou A vida nos bosques. São Paulo : Global, 1984

Walden; or, Life in the woods. New York : Dover Publications, Inc., 1995. Publicado originalmente em 1854

TUAN, Yi. Topofilia. São Paulo : Difel, 1980

Espaço e lugar. São Paulo : Difel, 1983

VAN MATRE, Steve - Acclimatizing. American Camping Association, USA, 1974

VEIGA, J. Espínola. A vida de quem não vê. Rio de Janeiro : José Olympio Editora, 1946

VELHO, Gilberto. Individualismo e cultura. Rio de Janeiro : Zahar, 1999

VIEIRA, Carmelindo de Souza. Alunos cegos egressos do Instituto Benjamin Constant no periodo de $1985-90$ e sua inserção comunitária. Tese de doutorado defendida no Instituto Fernandes Figueira, Fundação Oswaldo Cruz. 
$\because \because \because \because \because \because \because \because \because \quad \because \because \quad \because \because \because \because: \because \because$

WAGNER-LAMPL, A.; OLIVER, G. W. Bringing imagery into the world of visual impairment. Journal of Impaiment and Blindness, november 1988.

WELLS, Herbert George. The short story: The country of the blind and others stories. London : Longmans, 1954

WILKINSON, R. ; PICKET, K. The spirit level: Why greater equality makes societies stronger. Blumsburry Press, 2010

WIRTH, Louis. O urbanismo como modo de vida. in: VELHO. O fenômeno urbano. Rio de Janeiro : Zahar, 1967.

WHITE, Peter. See it my way. London : Warner Books, 1999

WOOLF, Virginia. Ao farol. Rio de Janeiro : Ediouro, 1993

Os diários. São Paulo : Companhia das Letras, 1989

WORSHEL, p. . \& DALLENBACH, K. M. Facial Vision : perception of obstacles by deaf-blind. American Journal of Psichology, $1947,60,502-553$

YAMAKI, Humberto. Cheiros da cidade: Paisagem olfativa Em: Quem tem medo do interior? Vol 1. Londrina : Editora UEL, 2001

Guia do Patrimônio Cultural de Londrina. Londrina, Humanidades, 2008

YÁZIGI, Eduardo. O mundo das calçadas. São Paulo : Humanitas/IOE, 2000.

ZARPELLON, Maurizio. I giardini dei sensi . Torino, Itália : Blu Edizioni, 2000 


\section{Endereços eletrônicos sobre deficiência e acessibilidade}

\section{African Union of the Blind}

http://www.afub.net/

\section{American Foundation for the Blind}

http://www.afb.org/

Journal of Impairment and Blindness

http://www.afb.org/jvib/jvib_main.asp

Associação Aliança dos Cegos

http://www.associacaoaliancadoscegos.com.br/

\section{Associação Baiana de Cegos}

http://www.associacaobaianadecegos.org.br/

Associação de Ballet e Arte para Cegos Fernanda Bianchini

http://www.ciafernandabianchini.org.br/

Associação Brasileira de Educadores de Deficientes Visuais

http://intervox.nce.ufrj.br/-abedev/

Associação Catarinense para Integração do Cego

http://www.acic.org.br/

Associação de Cegos do Estado do Ceará

http://sispub.oktiva.com.br/oktiva.net/1933/

Associação de cegos Louis Braille

p://www.deficientesvisuais.org.br/

http://www.acelb.org.br/

Associação de Cegos do Rio Grande do Sul

http://www.acergs.org.br/

Associação dos Cegos e Amblíopes de Portugal

http://www.acapo.pt/

Associação dos Cegos de Juiz de Fora

http://www.acegosjf.com.br/

Associação dos Deficientes Visuais de Bento Gonçalves

http://www.advbg.org.br/ 


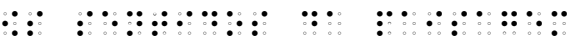

Associação dos Deficientes Visuais do Estado de Goiás

http://www.adveg.org.br/

Associação dos Deficientes Visuais de Ribeirão Preto

http://www.adevirp.com.br/

Associação dos Deficientes Visuais de Sergipe

http://adevise.com.br/

Associação Pernambucana de Cegos

http://www.apecnet.com.br/

ADEVA - Associação de deficientes visuais e amigos

http://www.adeva.org.br/

Associação dos Deficientes Visuais do Paraná

http://www.portaldacomunidade.pr.gov.br/modules/conteudo/conteudo.php?conteudo=19

Associação Filantrópica de Proteção aos Cegos

http://www.escolaparacegos.com/

Associação Fluminense de Amparo aos Cegos

http://www.afac.org.br/

Associação Sorocabana de Atividades para Deficientes Visuais

http://www.asac.org.br/

Banco de Escola - Educação para todos

http://www.bancodeescola.com/info_para_cegos.htm

Bengala Legal

http://www.bengalalegal.com.br

Braille Institute of America

http://brailleinstitute.org/

Braille na USP

http://www.braillevirtual.fe.usp.br/

Brighton Society for the Blind

http://www.bsblind.co.uk/

Creative Tactile Solutions

http://www.tactilesolutions.com/data2/news1.htm 


\section{Desenho Universal - Ron Mace}

http://www.adaptiveenvironments.org/adp/profiles/1_mace.php

http://www.adaptenv.org/index.php?option=Content\&Itemid=271\&pid=17

\section{Ecological Services and Consultancy}

http://www.ecologist.co.uk/interpretation.html

\section{Entre Amigos - sobre deficiências}

http://www.entreamigos.com.br/

\section{Esportes e acessibilidade}

http://www.abdcnet.com.br/

Fédération des Aveugles et handicapés Visuels de France http://www.fafasso.fr/

\section{Fundação Dorina Nowill}

http://www.fundacaodorina.org.br

Gardens for the Blind

http://www.trivia-library.com/b/gardens-of-the-world-for-the-blind.htm

\section{LARAMARA}

http://www.laramara.org.br/portugues/index.php

Ler para Ver - Portal para deficiência Visual

http://www.lerparaver.com/

\section{National Institute for the Visually Impaired}

http://www.nivi.edu.bt/

\section{Native American Museum}

http://www.nativeamericanmuseum.org/naturetrail.htm

\section{Organização dos Cegos de Espanha}

http://www.once.es/

\section{Percepção e a psicologia}

http://psychcentral.com/psypsych/Perception

http://psychcentral.com/

Perkins School for the Blind/ USA

http://www.perkins.org/

\section{Portal da Retina}

http://www.portaldaretina.com.br 


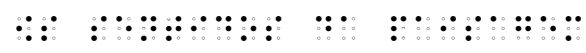

Produtos nacionais e importados para cegos

http://www.bengalabranca.com.br/

Rede Saci

http://www.saci.org.br/

Banco de dados sobre deficiência visual

http://www.defnet.org.br/

Royal National Institute of the Blind / UK

http://www.rnib.org.uk

Tactile Images for Visually Impaired Access

http://www.24hourmuseum.org.uk/nwh_gfx_en/ART17622.html

Technology and People with Visual Impairment

http://www.afb.org/aw/main.asp

The Center for the Advancement of the Blind - Israel

http://www.beityael.org/

The National Federation of the Blind of the United Kingdom

http://www.users.globalnet.co.uk/ nfbuk/

Unione Italiana dei Ciechi

http://www.uiciechi.it/

Visão Tátil

http://www.tactilevision.it/

\section{Artigos, trabalhos, pesquisas}

Architectural and Transportation Barriers Compliance Board http://www.fhwa.dot.gov/environment/sidewalks/appc.htm

David Hume - Filosofia e Percepção

http://www.consciencia.org/moderna/hume.shtml

IBSA (International Blind Sports Federation)

http://www.ibsa.es/

Itinerário Cultural para Cegos - Luxemburgo

http://www.useldeng.lu/kulturwee/gb_Perception.pdf 


\section{National Wildlife Federation}

http://www.nwf.org/nationalwildlife/article.cfm?issueID=37\&articleID=397

Site de psiquiatria do Dr G.J. Ballone

http://www.psiqweb.med.br/cursos/percep.html

Sociedade Brasileira de Atividade Motora Adaptada

http://www.sobama.org.br/

Sociedade de Assistência aos Cegos - S A C

http://www.sac.org.br/APRESENT.HTM

Secretaria Municipal de Educação de Belo Horizonte

http://www.lerparaver.com/amigos/elizabet_acessibilidade.html

Revista de fonoaudiologia

http://www.fonoaudiologia.org.br/REVISTA/vol-4-1/materia4-1.htm

Tese de Doutorado - Marcelo Medeiros Carneiro

- Dep. de Informática, PUC-Rio

http://www.tecgraf.puc-rio.br/ $\sim$ mmc/tese/

The Garden with no secrets - India

http://www.islamonline.net/english/science/2003/10/article04.shtml

The Washington Post - artigo

http://www.washingtonpost.com/wp-srv/travel/index/stories/houtchens07201997.htm

Trails for Visually Impaired

http://www.trailcenter.org/newsletter/1999/fall1999/fall99.htm

http://www.acessobrasil.org.br/index.php

http://www.adaptiveenvironments.org/

http://intervox.nce.ufrj.br/

\section{Mapas Táteis}

Maps and Graphics for Blind and Visually Impaired People http://www.surrey.ac.uk/ -pss1su/intact/

http://www.surrey.ac.uk/ pss1su/intact/intactabstracts.html

Visually Impaired People Can Improve Tactile map Design

http://www.surrey.ac.uk/ - pss1su/intact/icc97/perkinspaper.html 
Os sentidos da paisagem

$\because \because \quad \because \because \because: \because \because \because \because \quad \because \because \quad \because \because \because \because \because \because \because \because$

Tactile Images Give Visually Impaired

http:/www.24hourmuseum.org.uk/nwh_gfx_en/ART17622.html

Utilità del Disegno in Rilievo

http://www.tactilevision.it/

\section{Tactile Graphics}

http://www.lifesci.sussex.ac.uk/reginald-phillips/beginnersPaper.htm

Nature Trails

http://www.nativeamericanmuseum.org/naturetrail.htm

Can blind and visually impaired people read tilted braille labels?- Simon Ungar http://www.surrey.ac.uk/ pss1su/intact/Papers/Ungar.html

http://www.surrey.ac.uk/ p pss1su/intact/Papers/Ungar2.html

Visual impairment organisations in the UK and beyond

http://www.visugate.biz/index.htm

The Sensory Trust- Creating inclusive environments

http://www.sensorytrust.org.uk/information/iag/iag_ten.html 

Projeto Ponto a Ponto

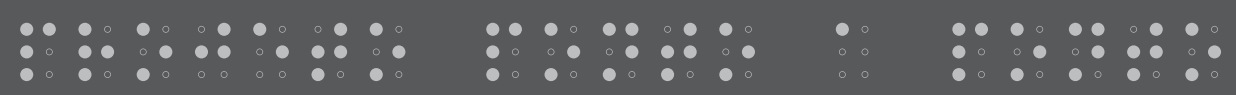




\section{Ministério da Cultura e Petrobras apresentam}

$\mathrm{O}$ acesso à comunicação, no mais amplo sentido, é o acesso ao conhecimento, e este é vitálmente importante para que nós năo continuemos menosprezados e dependentes das pessoas que enxergam.

Louis Braille (1809-1852)

\section{Histórico}

No final de 1994, teve início um projeto inovador no Brasil, voltado a pessoas com deficiência visual que conhecem a escrita braille. Trata-se do Ponto a Ponto ${ }^{\circ}$, criado por Silvia Valentini a partir de um trabalho voluntário feito em biblioteca de livros gravados para cegos. Estimulada pela convivência com pessoas cegas usuárias da biblioteca e pelo aprendizado do braille, a artista plástica e paisagista criou um banco de endereços de pessoas interessadas em se corresponder em braille. Dessa forma, elas passaram a ampliar seu contato com o mundo e a fazer novas amizades, além de adquirir mais intimidade com a escrita braille. A remessa das cartas nẫo é cobrada pelo correio, bastando que se escreva no envelope a palavra "cecograma".

Os inscritos, com idade entre 8 e 87 anos, aprendem idiomas, jogam xadrez, trocam informaçóes, poesias, fitas gravadas, sementes de plantas e curiosidades sobre seu país, reencontram amigos de infância que julgavam falecidos e até se envolvem afetivamente - o Ponto a Ponto ${ }^{\circ}$ já registra cinco casamentos entre os participantes. As 3 mil cartas recebidas trazem verdadeiras liçôes de vida. Sáo quase 400 sócios cegos de 40 países*, que se comunicam em português, inglês e espanhol. Vários inscritos, inclusive, sáo poliglotas, como um jovem estudante de letras da Universidade do Cairo que se corresponde em seis idiomas.

A correspondência é toda feita em braille, usando papel reciclado com gramatura em torno de $90 \mathrm{gr}$, aproveitado de catálogos obsoletos ou relatórios anuais de empresas, papel que seria descartado e que produz um braille de excelente qualidade. Os envelopes utilizam folhas de revistas impressas em braille, doadas pelos sócios. A troca de correspondência ganhou vida própria e os participantes já compartilham novos endereços.
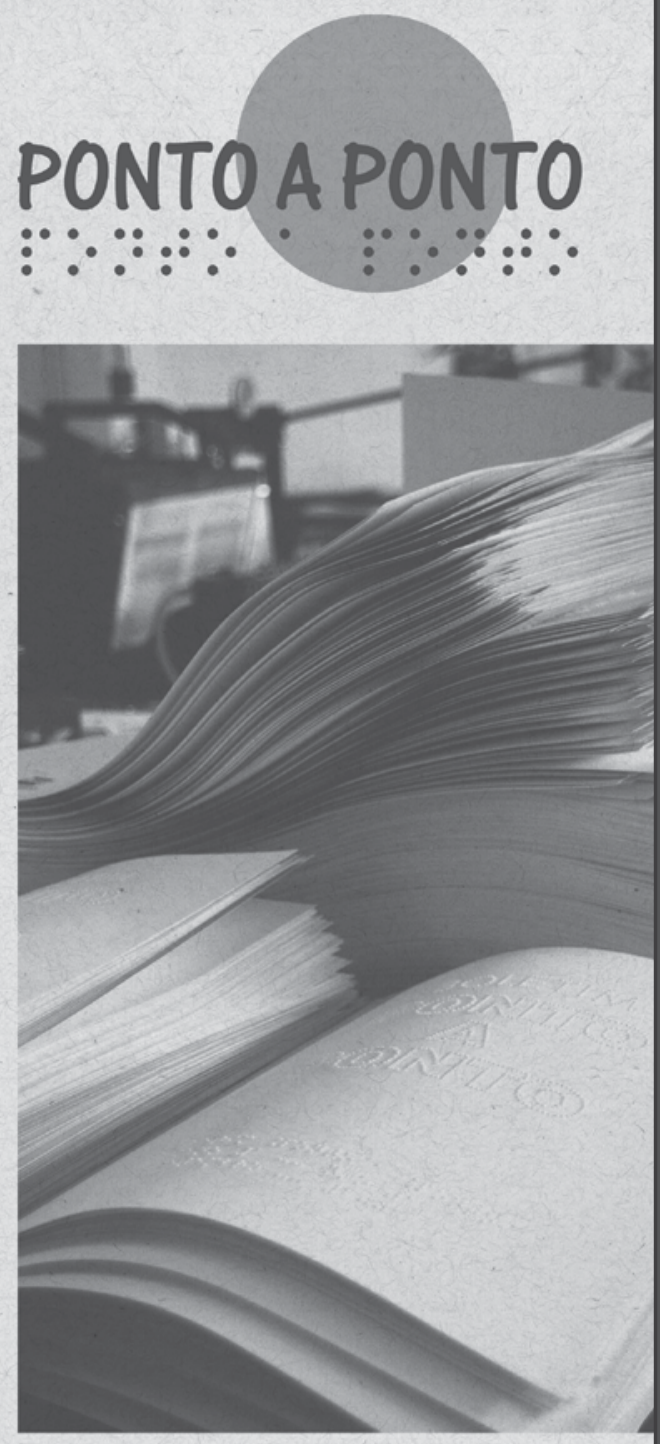

*Países que participam do Ponto a Ponto", por ordem de chegada no projeto: Brasil. Portugal, Espanha; Argentina, Uruguai, Peru, Costa Rica, México, Egito, Cuba, Moçambique, França, Estados Unidos, Alemanha, Marrocos, Canadá, Bulgária, Bolivia, Porto Rico, República Dominicana, República Tcheca, Inglaterra, China, India, Zàmbia, Venezuela, Zimbábue, Etiópia, Malaui, Uganda, Kenia, Miamar, Cingapura, Israel, Filipinas, Nigéria, Bangladesh, Argélia, Tanzânia e Costa do Marfim. 


\section{Nasce o Boletim}

\section{Ponto a Ponto ${ }^{(}$}

A partir de 1995 começaram a se inscrever no Ponto a Ponto pessoas com dupla deficiência - surdocegos. Para essas pessoas Silvia passou a transcrever para braille artigos de jornais e revistas dando origem ao Boletim Ponto a Ponto $^{\circ}$. Aproximadamente 300 títulos foram transcritos manualmente, alguns deles contendo ilustraçōes em relevo, para percepçáo tátil. O papel é reciclado e os volumes sáo encadernados com espiral e capa cartonada, material também reaproveitado.

Uma jovem adolescente, após ler um artigo sobre o funcionamento dos lados direito e esquerdo do cérebro, que descrevia uma pesquisa científca feita com sapos, comentou: "Não é verdade que eu náo gosto de nada, que náo me interesso por nada. É que eu náo sabia que essas coisas existiam! Mande mais artigos".

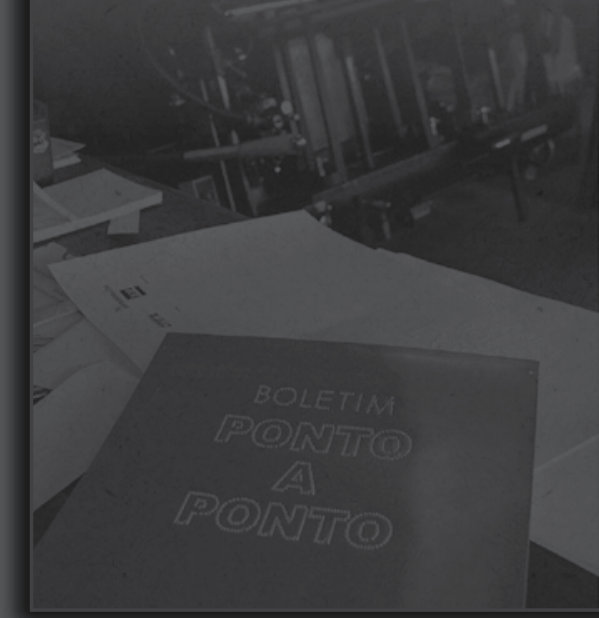

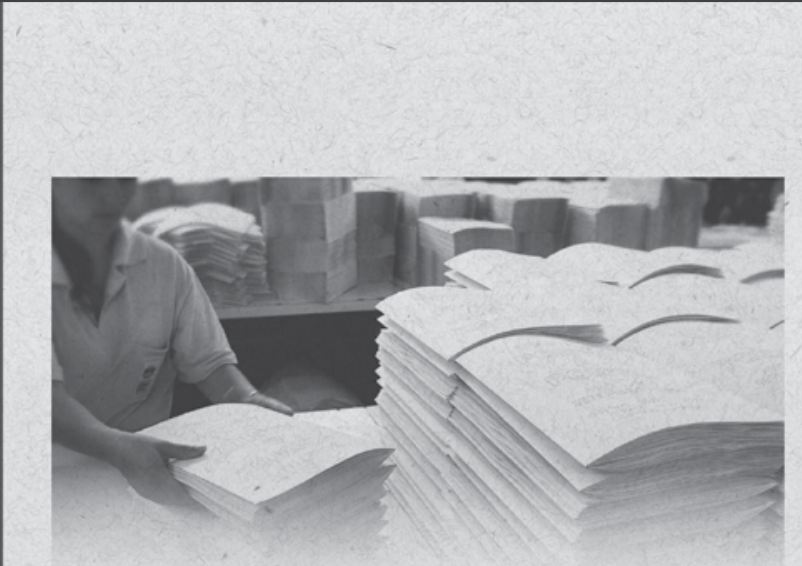

\section{Petrobras e o Boletim}

\section{Ponto a Ponto ${ }^{\circ}$}

Desde setembro de 2008, o boletim conta com o apoio da Lei Rouanet e o patrocínio da Petrobras, tendo sido um dos 263 projetos selecionados entre mais de 7 mil concorrentes. A publicaçáo é distribuída gratuitamente para leitores cegos e instituiçōes de todo o Brasil, assim como para bibliotecas públicas do Brasil, de Portugal e da África.

Transcritos de jornais e revistas para o braille, os artigos integram as seçóes de pessoas, negócios e profissóes, estilo de vida e comportamento, ecologia e meio ambiente, educaçáo e cultura, literatura e língua portuguesa, ciências, turismo e saúde. Cabe aqui considerar que a transcriçáo de artigos e obras literárias para braille náo constitui ofensa aos direitos autorais, graças à lei 9.610, de 19 de fevereiro de 1998.

Alguns dos artigos sáo ilustrados em relevo e essa ilustraçáo, trabalhada para se adequar ao entendimento tátil. As 12 ediçốes anuais têm tiragem de 2 mil exemplares. A Fundaçáo Dorina Nowill para Cegos cuida da editoraçáo, impressáo e distribuiçáo do boletim, enviado pelos Correios como cecograma, modalidade franqueada e reservada ao material escrito em braille.

Muitas vezes, as pessoas cegas e surdacegas cometem erros de ortografia por falta de contato com a leitura e a escrita. Há poucas revistas em braille no mercado e as bibliotecas especializadas situam-se apenas nos grandes centros, dificultando o acesso à informaçáo. Como as ediçôes em braille sấo onerosas, a maior oferta de leitura vem em fitas gravadas, de grande ajuda para os cegos, mas que náo atende aos surdocegos, nem ensina a escrever corretamente. "Além disso, o braille é um encantamento, um escultura. Uma folha escrita em braille vira uma peça tridimensional que faz superar limites", diz Silvia Valentini. 


\section{Boletim Ponto a}

\section{Ponto $^{\circ}$ - Ano II}

Em 2011, o Boletim Ponto a Ponto ${ }^{\circ}$ retorna como projeto convidado da Petrobras, refletindo o sucesso do primeiro ano, além de revelar o empenho da empresa na construçáo de um mundo socialmente justo, por meio do reconhecimento da importância da escrita braille e da cultura como direito social básico do cidadáo.

Neste segundo ano, a publicaçáo conta também com o apoio da multinacional KPMG, conhecida por sua preocupaçăo social e cultural. Essa parceria propicia a ampliaçáo do número de páginas impressas, um dos pedidos mais frequentes dos leitores.

Encartado no boletim, um cartáo-resposta facilita o exercício da escrita braille pelos leitores. Durante o primeiro ano, o projeto recebeu mais de 800 retornos com elogios e sugestóes, assinalando a qualidade da publica- çáo, a escassez de material em braille e a falta de acesso à informaçáo e ao conhecimento, constantes no cotidiano das péssoas cegas. Fartamente noticiado pela mídia, o Boletim também ganhou destaque em blogs e espaços institucionais de órgáos públicos e privados.

\section{Novas parcerias}

O Boletim é publicado com um mínimo de 60 páginas, lidas muito rapidamente pelos leitores. A intençáo é crescer e alcançar 120 páginas e, para isso, precisamos de novas parcerias. Aprovado pela Lei Rouanet, o boletim possibilita renúncia fiscal para pessoas físicas e jurídicas. Junte-se a nós e faça parte de um projeto que propicia às pessoas com deficiência visual, por meio da escrita em braille, o acesso ao conhecimento e a superaçáo de seus próprios limites.
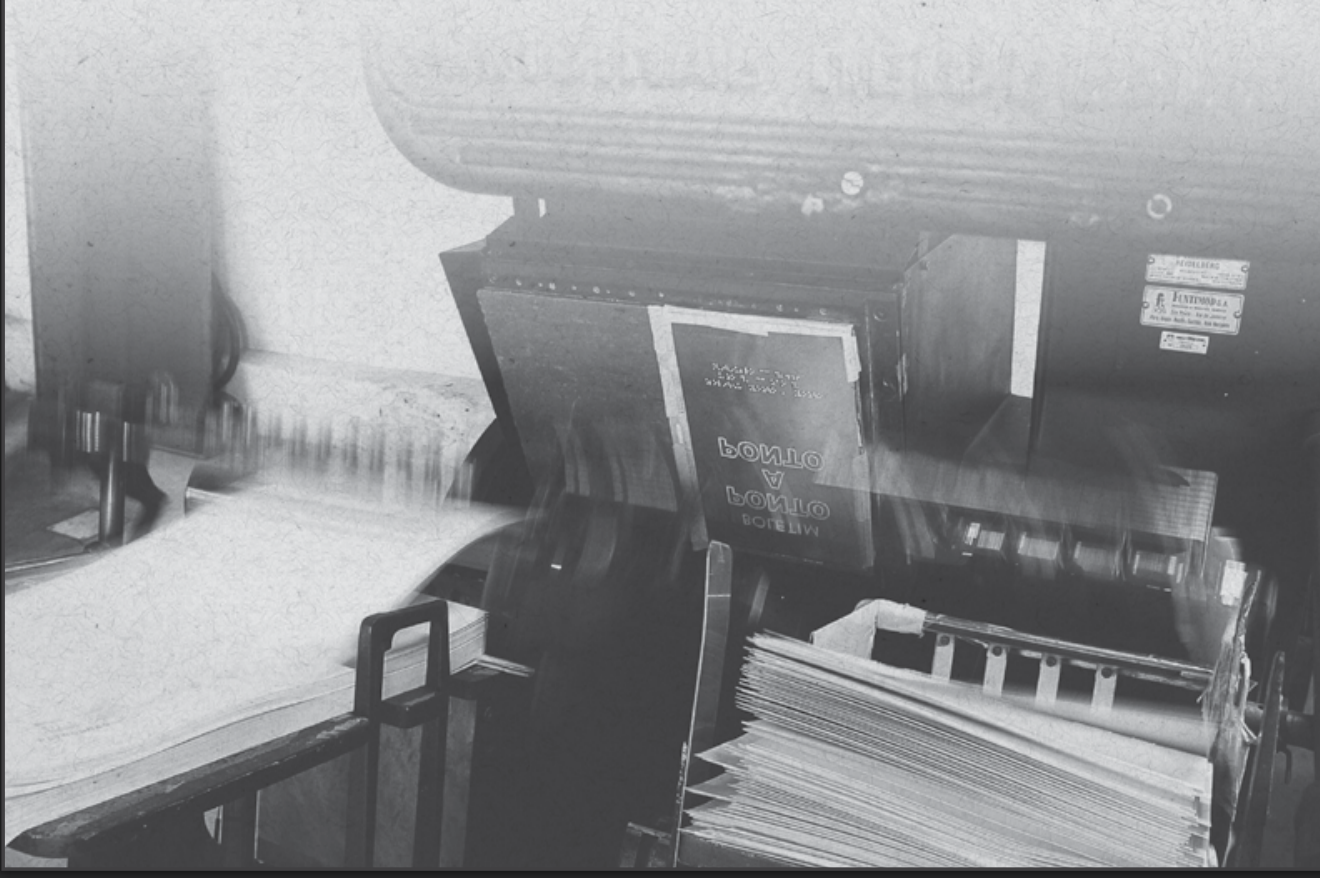


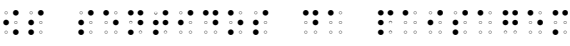

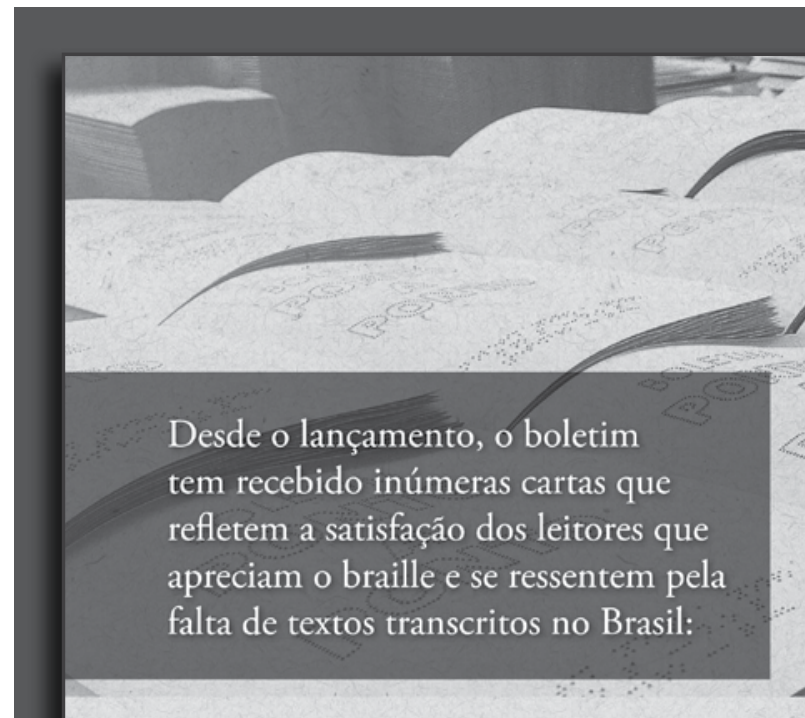

- "O recebimento do Boletim Ponto a Ponto ${ }^{\circ}$ tem sido de grande valia para nós, deficientes visuais, pois nos proporciona o inigualável prazer do contato com a leitura braille", Juliana (PR).

- "Gostaria que soubessem o quanto o meu marido Eduardo gosta e se sente feliz em receber o boletim aqui em casa, principalmente aquela ediçáo do carrapato, em que ele pôde perceber o desenho, tateou os detalhes... nossa, ele ficou radiante!", Márcia (SP).

- "Agradeço pelo boletim, pois ele está sendo de grande importância. Os deficientes visuais têm lido e discutido comigo os variados assuntos. Transformamos nossos encontros em atividades culturais", Daniela (SP).

- "Concordo com muitos amigos deficientes visuais que temos carência de publicaçōes em braille, porém, fazer qualquer coisa é fácil. Uma publicaçáo com bom conteúdo, diversificados assuntos, atualizada e com braille de boa qualidade, isso náo é comum. A cada exemplar que recebo fico emocionada", Sandra (SP).

- "Após ler a terceira ediçáo do boletim, pouco tenho a dizer, pois ele sempre nos surpreende. E sei que vocês váo

escolher artigos que nos agradem. Só tenho a agradecer a valiosa ajuda dada para ampliar nosso conhecimento e fazer com que o braille continue vivo", Eva (SP).

- "Parabenizando pelo belíssimo trabalho com o boletim. Difícil é expressar em palavras a emoçáo que sinto a cada vez que tenho a oportunidade de ler em braille. Obrigada por ter me proporcionado esse indescritível prazer! Parabéns pelo ideal que se concretizou e, sobretudo, obrigada por se interessar pela bandeira do braille", Aparecida (RJ).

- "Escrevo hoje para destacar alguns aspectos que foram muito importantes para mim nesta ediçáo do nosso boletim, com artigos interessantes e gostosos de ler, além da impressão e qualidade excelentes: adorei o artigo que fala do sal e dos mares. A ilustraçáo está maravilhosa e totalmente compreensível a uma pessoa cega. Achei perfeita a maneira como ela foi organizada e pensada", Juliana (RS).

- "É sempre com grande expectativa e ansiedade que aguardo a chegada do boletim. Leio logo o índice e o editorial, depois as reportagens. Pena que a revista acaba tão rápido", Cris (SP).
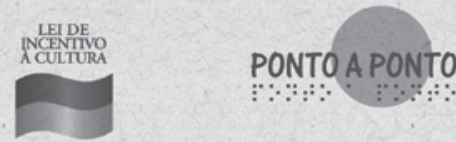

Patrocinio

Realizą̧ăo

BR PETROBRAS Ministério do 
